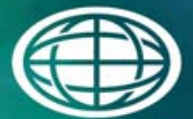

Savannah River

National Laboratory "m

OPERATED BY SAVANNAH RIVER NUCLEAR SOLUTIONS

\title{
Actual Waste Testing of Glycolate Impacts on the SRS Tank Farm
}

C.J. Martino

May 2014

SRNL-STI-2013-00322, Revision 0 
SRNL-STI-2013-00322

Revision 0

\section{DISCLAIMER}

This work was prepared under an agreement with and funded by the U.S. Government. Neither the U.S. Government or its employees, nor any of its contractors, subcontractors or their employees, makes any express or implied:

1. warranty or assumes any legal liability for the accuracy, completeness, or for the use or results of such use of any information, product, or process disclosed; or

2. representation that such use or results of such use would not infringe privately owned rights; or

3. endorsement or recommendation of any specifically identified commercial product, process, or service.

Any views and opinions of authors expressed in this work do not necessarily state or reflect those of the United States Government, or its contractors, or subcontractors.

\section{Printed in the United States of America \\ Prepared for U.S. Department of Energy}


Keywords: $2 H$ Evaporator, DWPF

Alternate Reductant, Uranium, Plutonium, Sodium Aluminosilicate

Retention: Permanent

\title{
Actual Waste Testing of Glycolate Impacts on the SRS Tank Farm
}

\author{
C.J. Martino
}

May 2014

Prepared for the U.S. Department of Energy under contract number DE-AC09-08SR22470. 


\section{REVIEWS AND APPROVALS}

\section{AUTHORS:}

C.J. Martino, Advanced Characterization and Processing Date

TECHNICAL REVIEW:

M.S. Hay, Advanced Characterization and Processing, Reviewed per E7 2.60

Date

APPROVAL:

F.M. Pennebaker, Manager

Date

Advanced Characterization and Processing

S.L. Marra, Manager

Date

Environmental \& Chemical Process Technology Research Programs

D.J. Martin, Manager

Date

SRR Treatment Process Engineering

E.J. Freed, Manager

Date

SRR DWPF Facility Engineering

J.S. Contardi, Manager

Date

SRR Tank Farm Facility Engineering 


\section{ACKNOWLEDGEMENTS}

The success of this task was due in large part by the thorough planning initiated by Kofi Adu-Wusu. Michael Stone and Terri Fellinger were instrumental in helping to refine the scope of this task to cover the applicable down-stream impacts fully, yet efficiently. I wish to thank the technicians who performed the actual waste testing: Dee Wheeler, Nan Stanley, and Phyllis Burkhalter; and the supply preparation: Betty Mealer. Many chemists and technicians within the SRNL Analytical Development section were essential in providing the analytical data for this study. 
SRNL-STI-2013-00322

Revision 0

\section{EXECUTIVE SUMMARY}

Glycolic acid is being studied as a replacement for formic acid in the Defense Waste Processing Facility (DWPF) feed preparation process. After implementation, the recycle stream from DWPF back to the high-level waste Tank Farm will contain soluble sodium glycolate. Most of the potential impacts of glycolate in the Tank Farm were addressed via a literature review and simulant testing, but several outstanding issues remained.

This report documents the actual-waste tests to determine the impacts of glycolate on storage and evaporation of Savannah River Site high-level waste. The objectives of this study are to address the following:

- Determine the extent to which sludge constituents $(\mathrm{Pu}, \mathrm{U}, \mathrm{Fe}$, etc.) dissolve (the solubility of sludge constituents) in the glycolate-containing $2 \mathrm{H}$-evaporator feed.

- Determine the impact of glycolate on the sorption of fissile ( $\mathrm{Pu}, \mathrm{U}$, etc.) components onto sodium aluminosilicate solids.

The first objective was accomplished through actual-waste testing using Tank $43 \mathrm{H}$ and $38 \mathrm{H}$ supernatant and Tank $51 \mathrm{H}$ sludge at Tank Farm storage conditions. The second objective was accomplished by contacting actual $2 \mathrm{H}$-evaporator scale with the products from the testing for the first objective.

There is no anticipated impact of up to $10 \mathrm{~g} / \mathrm{L}$ of glycolate in DWPF recycle to the Tank Farm on tank waste component solubilities as investigated in this test.

Most components were not influenced by glycolate during solubility tests, including major components such as aluminum, sodium, and most salt anions. There was potentially a slight increase in soluble iron with added glycolate, but the soluble iron concentration remained so low (on the order of $10 \mathrm{mg} / \mathrm{L}$ ) as to not impact the iron to fissile ratio in sludge.

Uranium and plutonium appear to have been supersaturated in $2 \mathrm{H}$-evaporator feed solution mixture used for this testing. As a result, there was a reduction of soluble uranium and plutonium as a function of time. The change in soluble uranium concentration was independent of added glycolate concentration. The change in soluble plutonium content was dependent on the added glycolate concentration, with higher levels of glycolate $(5 \mathrm{~g} / \mathrm{L}$ and $10 \mathrm{~g} / \mathrm{L})$ appearing to suppress the plutonium solubility.

The inclusion of glycolate did not change the dissolution of or sorption onto actual-waste $2 \mathrm{H}$-evaporator pot scale to an extent that will impact Tank Farm storage and concentration. The effects that were noted involved dissolution of components from evaporator scale and precipitation of components onto evaporator scale that were independent of the level of added glycolate. 


\section{TABLE OF CONTENTS}





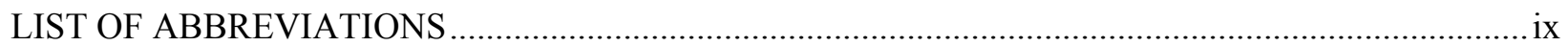

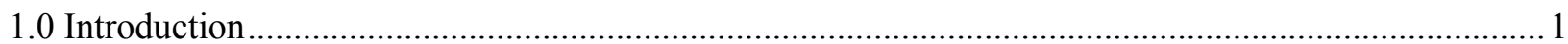

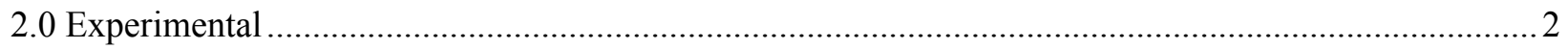

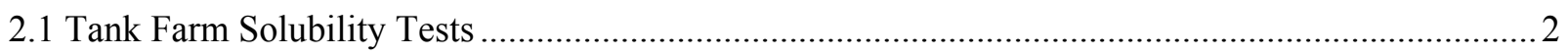

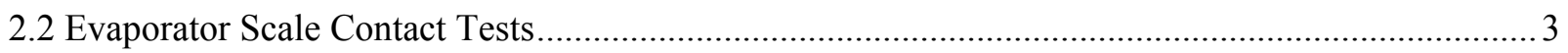

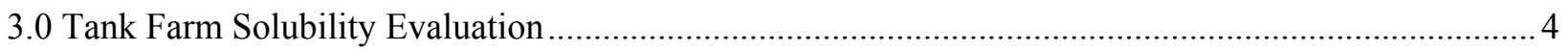

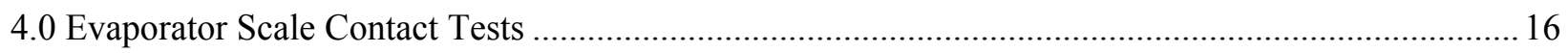

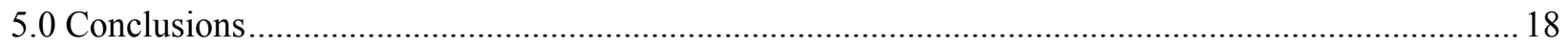

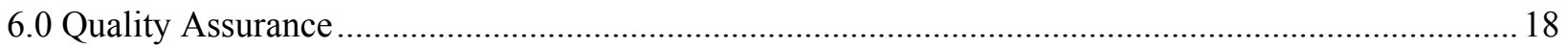



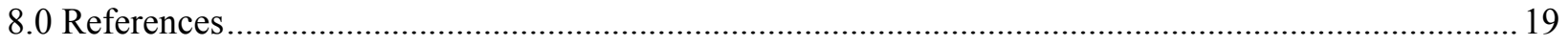

Appendix A . Results for Replicate Analyses .............................................................................20 
SRNL-STI-2013-00322

Revision 0

\section{LIST OF TABLES}

Table 2-1. Actual-waste materials used for the sodium glycolate Tank Farm impacts testing..................2

Table 3-1. Elemental composition analysis of the soluble portion of $2 \mathrm{H}$ Evaporator feed solution held in

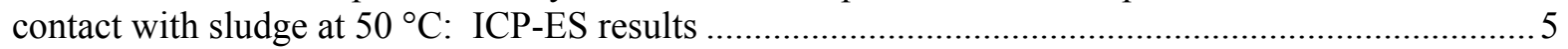

Table 3-2. Analysis of the soluble portion of $2 \mathrm{H}$ Evaporator feed solution held in contact with sludge at $50{ }^{\circ} \mathrm{C}$ : ICP-MS and plutonium results 6

Table 3-3. Analysis of the soluble portion of $2 \mathrm{H}$ Evaporator feed solution held in contact with sludge at $50{ }^{\circ} \mathrm{C}$ : IC anions, $\mathrm{OH}^{-}$and TIC/TOC results ... 7

Table 3-4. Analysis of reference solutions run with 0 day, 14 day and 35 day sample sets .14

Table 4-1. Results from testing of sodium aluminosilicate evaporator scale contact with solutions that have contacted sludge, where 0 and $10 \mathrm{~g} / \mathrm{L}$ glycolate ion are present 17

\section{LIST OF FIGURES}

Figure 3-1. Influence of glycolate on soluble aluminum concentration in SRS Tank Farm actual-waste salt solution in contact with sludge at $50{ }^{\circ} \mathrm{C}$.

Figure 3-2. Influence of glycolate on soluble iron concentration in SRS Tank Farm actual-waste salt solution in contact with sludge at $50{ }^{\circ} \mathrm{C}$

Figure 3-3. Influence of glycolate on soluble uranium concentration in SRS Tank Farm actual-waste salt solution in contact with sludge at $50{ }^{\circ} \mathrm{C}$

Figure 3-4. Evaluation of the equilibrium solubility of uranium in $2 \mathrm{H}$ Evaporator salt solution testing at $50{ }^{\circ} \mathrm{C}$

Figure 3-5. Influence of glycolate on soluble Pu-238 activity in SRS Tank Farm actual-waste salt solution in contact with sludge at $50{ }^{\circ} \mathrm{C}$

Figure 3-6. Influence of glycolate on soluble plutonium concentration in SRS Tank Farm actual-waste

salt solution in contact with sludge at $50{ }^{\circ} \mathrm{C}$. 13 


\section{LIST OF ABBREVIATIONS}

$\begin{array}{ll}\text { AD } & \text { Analytical Development } \\ \text { CVAA } & \text { Cold Vapor Atomic Absorption } \\ \text { DWPF } & \text { Defense Waste Processing Facility } \\ \text { ETF } & \text { Effluent Treatment Facility } \\ \text { IC } & \text { Ion Chromatography } \\ \text { ICP-ES } & \text { Inductively Coupled Plasma - Emission Spectroscopy } \\ \text { ICP-MS } & \text { Inductively Coupled Plasma - Mass Spectroscopy } \\ \text { n/a } & \text { not applicable } \\ \text { PSAL } & \text { Process Science Analytical Laboratory } \\ \text { PuTTA } & \text { Plutonium separation by thenoyltrifluoracetone } \\ \text { RSD } & \text { Relative Standard Deviation } \\ \text { SRNL } & \text { Savannah River National Laboratory } \\ \text { SRR } & \text { Savannah River Remediation } \\ \text { SRS } & \text { Savannah River Site } \\ \text { TIC/TOC } & \text { Total Inorganic Carbon / Total Organic Carbon } \\ \text { TTQAP } & \text { Task Technical and Quality Assurance Plan } \\ \text { VDS } & \text { Variable Depth Sample }\end{array}$


SRNL-STI-2013-00322

Revision 0

\subsection{Introduction}

Savannah River Remediation (SRR) is evaluating changes to its current Defense Waste Processing Facility (DWPF) flowsheet to reduce facility hazards and improve processing cycle times. As a result, glycolic acid is being studied as an alternate reductant in DWPF as a replacement for formic acid that is currently used. ${ }^{1,2}$ Due to glycolic acid in the Chemical Processing Cell condensate and Melter off-gas, the DWPF process flowsheet with glycolic acid as the reductant may result in as much as $10 \mathrm{~g} / \mathrm{L}$ of glycolate in the DWPF recycle stream sent to the Savannah River Site (SRS) Tank Farm. ${ }^{3}$

A literature review was conducted on the impact of glycolate on several post-DWPF downstream systems: storage in the Tank Farm, evaporation in the $2 \mathrm{H}$ Evaporator system, and evaporator condensate processing through the Effluent Treatment Facility (ETF). ${ }^{3}$ The literature search emphasized that glycolic acid, and to a lesser extent glycolate ion, has the ability to complex many multivalent metals and increase their solubility. The complexing ability of glycolate at high $\mathrm{pH}$ has been shown for the lanthanides and several actinides. This complexing or solubilizing ability of glycolate may be a potential criticality concern for Tank Farm storage of the DWPF recycle stream and subsequent processing in the $2 \mathrm{H}-$ evaporator system.

This report documents actual-waste tests on the storage and evaporator impacts of glycolate in the Tank Farm, where glycolate will be in contact with radioactive components of the tank sludge and the evaporator scale. These tasks are derived from the scope outlined in the Technical Task Request and further detailed in the Task Technical and Quality Assurance Plan (TTQAP). ${ }^{4,5}$

A previous report documented non-radioactive simulant tests for glycolate partitioning during Tank Farm waste evaporation (i.e., into evaporator concentrate versus evaporator condensate) and the impacts of glycolate on cation solubility in Tank Farm waste. ${ }^{6}$ Because the majority of the glycolate stays with the evaporator concentrate, studies have also investigated the impacts of glycolate on downstream salt processing facilities. ${ }^{7,8}$

This report addresses tests with actual-waste material to represent the $2 \mathrm{H}$-evaporator system storage tanks. The objectives of this study are to perform tests to address the following:

- Determine the extent to which sludge constituents $(\mathrm{Pu}, \mathrm{U}, \mathrm{Fe}$, etc.) dissolve (the solubility of sludge constituents) in the glycolate-containing $2 \mathrm{H}$-evaporator feed.

- Determine the impact of glycolate on the sorption of fissile ( $\mathrm{Pu}, \mathrm{U}$, etc.) components onto sodium aluminosilicate solids.

The first objective was accomplished through actual waste testing using Tank $43 \mathrm{H}$ and $38 \mathrm{H}$ supernatant and Tank $51 \mathrm{H}$ sludge at Tank Farm storage conditions. The second objective was accomplished by contacting actual $2 \mathrm{H}$-evaporator pot scale with the products from the testing for the first objective. The data generated will be used in the OLI modeling task as appropriate. 9 


\subsection{Experimental}

Two types of testing with actual waste were performed. The testing used a combination of previously obtained actual SRS waste materials from characterization and qualification programs. Table 2-1 contains a listing of the samples that were used in both types of testing. The first type of testing, to evaluate the impact of glycolate on the solubility of sludge components in the Tank Farm, was conducted using a mixture of supernate samples from Tank $43 \mathrm{H}$ and $38 \mathrm{H}$ and sludge from Tank $51 \mathrm{H}$ at Tank Farm storage conditions. The second type of testing, to evaluate the impact of glycolate on the components sorbed onto the $2 \mathrm{H}$-evaporator pot scale, used the soluble portion (equilibrated and filtered) of the product from the first type of testing and a sample of $2 \mathrm{H}$-evaporator pot scale.

Table 2-1. Actual-waste materials used for the sodium glycolate Tank Farm impacts testing

\begin{tabular}{c|c|c|c}
\hline Source & Sample Names & Sample Mass & Analysis \\
\hline Tank 38H & $\begin{array}{c}\text { HTF-38-11-137 and } 138 \\
\text { HTF-38-11-51 } \\
\text { HTF-38-12-103 and } 104\end{array}$ & $427.17 \mathrm{~g}$ & $\begin{array}{c}\text { Refs. 10, 11, } \\
\text { and } 12\end{array}$ \\
\hline Tank 43H & $\begin{array}{c}\text { HTF-43-12-53 and 54 } \\
\text { HTF-43-12-105 and } 106\end{array}$ & $317.56 \mathrm{~g}$ & Refs. 11 and 12 \\
\hline Tank 51H & HTF-51-12-80 & $17.14 \mathrm{~g}$ & Refs. 13 and 14 \\
\hline $\begin{array}{c}\text { 2H-evaporator } \\
\text { pot scale }\end{array}$ & HTF-13-11 $(28 \mathrm{H})$ & $4.26 \mathrm{~g}$ & Ref. 15 \\
\hline
\end{tabular}

The previous characterization of the materials used in this testing are contained in the references listed in Table 2-1. The Tank $38 \mathrm{H}$ and $43 \mathrm{H}$ feed solutions are typically 2.5 to $3 \mathrm{M}$ sodium hydroxide, 1.5 to $2 \mathrm{M}$ sodium nitrite and about $1 \mathrm{M}$ sodium nitrate with smaller amounts of other salts. The Tank $38 \mathrm{H}$ and $43 \mathrm{H}$ solutions typically contain around $60 \mathrm{mg} / \mathrm{L}$ of uranium and $20,000 \mathrm{dpm} / \mathrm{mL}$ of $\mathrm{Pu}-238$. The Tank $51 \mathrm{H}$ material used in these tests was washed Sludge Batch 8 slurry (identified as "SRAT Receipt" in Reference 13). Tank $51 \mathrm{H}$ has received a variety of materials, but the majority of the Sludge Batch 8 material in Tank $51 \mathrm{H}$ was Tank $12 \mathrm{H}$ sludge from which a large portion of the aluminum had been previously dissolved. The Tank $51 \mathrm{H}$ washed Sludge Batch 8 material contained $17.2 \mathrm{wt} \%$ iron, $5.5 \mathrm{wt} \%$ aluminum, $2.6 \mathrm{wt} \%$ uranium and $3.84 \times 10^{8} \mathrm{dpm} / \mathrm{g}$ plutonium- 238 on a total solids basis. The $2 \mathrm{H}$-evaporator pot scale was primarily nitrated cancrinite (sodium aluminosilicate) with $12 \mathrm{wt} \%$ mercury and $7 \mathrm{wt} \%$ uranium.

\subsection{Tank Farm Solubility Tests}

A stock mixture was made containing tank supernate and sludge solids. This Tank $38 \mathrm{H} / 51 \mathrm{H}$ stock mixture contained 17.14 grams of Tank $51 \mathrm{H}$ slurry and 126.23 grams of Tank $38 \mathrm{H}$ supernate sample composite. Individual $15 \mathrm{~mL}$ bottles were prepared for each solubility test, containing nominally 12 grams of Tank $43 \mathrm{H}$ supernate sample composite, 4 grams of the Tank $38 \mathrm{H} / 51 \mathrm{H}$ stock mixture, and the corresponding quantity of sodium glycolate salt to achieve the target glycolate concentration. The slurries prepared for the equilibration tests included $0.4 \mathrm{wt} \%$ of Tank $51 \mathrm{H}$ sludge solids. Sufficient sludge was 
present to be able to raise the solution levels by $1460 \mathrm{mg} / \mathrm{L}$ iron, $470 \mathrm{mg} / \mathrm{L}$ aluminum, $220 \mathrm{mg} / \mathrm{L}$ uranium and $3.27 \times 10^{6} \mathrm{dpm} / \mathrm{g}$ plutonium-238 if complete dissolution or complexation occurred.

The targeted glycolate concentrations for inclusion were $0 \mathrm{~g} / \mathrm{L}, 5 \mathrm{~g} / \mathrm{L}$ and $10 \mathrm{~g} / \mathrm{L}$. Because it is doubtful that such large quantities of glycolate $(5$ and $10 \mathrm{~g} / \mathrm{L})$ would be sent to the Tank Farm, solubilities in a more realistic $0.2 \mathrm{~g} / \mathrm{L}$ of glycolate was checked for a subset of the equilibration times.

Initial feed analysis was performed on $15 \mathrm{~mL}$ samples processed after sitting at room temperature for about an hour. For the other time periods, these individual sample bottles were placed in a nominally $50{ }^{\circ} \mathrm{C}$ shaker oven for periods of $7,14,21$, and 35 days. Several extra $15 \mathrm{~mL}$ sample bottles were prepared and placed in the oven in case that repeated sampling was necessary. Duplicate bottles were prepared and processed for most of the 35 day conditions. A second thermocouple that was placed into the main chamber of the shaker oven read $52{ }^{\circ} \mathrm{C}$, indicating that the equilibration temperature may have been biased slightly high.

After the target time at temperature had been reached, samples were removed from the oven and prepared for analysis of soluble components. Portions of the slurries were filtered through $0.45 \mu \mathrm{m}$ nylon filters, and the filtrate was used to prepare two acid diluted aliquots and one water diluted aliquot (nominal tenfold dilutions). Acidic dilutions were analyzed by Inductively Coupled Plasma - Emission Spectroscopy (ICP-ES), Inductively Coupled Plasma - Mass Spectroscopy (ICP-MS), and plutonium analysis by thenoyltrifluoracetone separation (PuTTA) and alpha counting. Water dilutions were analyzed by titration for free hydroxide, Ion Chromatography (IC) for anions, and Total Inorganic Carbon/Total Organic Carbon (TIC/TOC) for carbonate and organic carbon.

\subsection{Evaporator Scale Contact Tests}

Materials analogous to the equilibrated end products from the Tank Farm solubility tests were needed for the evaporator scale contact tests. Additional salt solution and sludge mixtures with $0 \mathrm{~g} / \mathrm{L}$ and $10 \mathrm{~g} / \mathrm{L}$ of added glycolate were prepared by the method described in the previous section, equilibrated for 48 days in a shaker oven at $50{ }^{\circ} \mathrm{C}$, and filtered with $0.45 \mu \mathrm{m}$ nylon filters. The main difference from the previous testing is that Tank $38 \mathrm{H}$ sample material diluted with de-ionized water was substituted for Tank $43 \mathrm{H}$ sample material.

Individual $15 \mathrm{~mL}$ bottles were prepared containing nominally 0.7 grams of $2 \mathrm{H}$-evaporator pot scale and 11 grams of equilibrated and filtered product from the sludge contact test. Four bottles each were prepared for $0 \mathrm{~g} / \mathrm{L}$ and $10 \mathrm{~g} / \mathrm{L}$ of added glycolate. One bottle for each level of added glycolate was processed as the initial feed analysis. The other three bottles for each level of added glycolate were placed in a nominally $80^{\circ} \mathrm{C}$ shaker oven for a period of 19 or 20 days. A second thermocouple that was placed into the main chamber of the shaker oven read $82{ }^{\circ} \mathrm{C}$, indicating that the equilibration temperature may have been biased slightly high.

After the target time at temperature had been reached, samples were removed from the oven and prepared for analysis of soluble components. Portions of the slurries were filtered through $0.45 \mu \mathrm{m}$ nylon filters, and the filtrate was used to prepare one acid diluted aliquot and one water diluted aliquot (nominal tenfold dilutions). Acidic dilutions were analyzed by ICP-ES, ICP-MS, plutonium analysis, and Cold Vapor Atomic Absorption (CVAA) analysis for mercury. Water dilutions were analyzed by titration, IC, and TIC/TOC. 
SRNL-STI-2013-00322

Revision 0

\subsection{Tank Farm Solubility Evaluation}

The densities of Tank $43 \mathrm{H}$ and Tank $38 \mathrm{H}$ sample composites were measured at $15^{\circ} \mathrm{C}$ as $1.23 \mathrm{~g} / \mathrm{mL}$ and $1.34 \mathrm{~g} / \mathrm{mL}$, respectively. The individual Tank $43 \mathrm{H} / 38 \mathrm{H} / 51 \mathrm{H}$ mixtures used throughout this testing has a calculated density of $1.25 \mathrm{~g} / \mathrm{mL}$ at $15^{\circ} \mathrm{C}$.

Table 3-1, Table 3-2 and Table 3-3 contain the results of the analysis of samples taken during testing, including the averages and relative standard deviations (RSD) of duplicate or quadruplicate analyses. Results are organized for each individual analyte with columns representing each time interval $(0,7,14$, 21 , and 35 days) and rows representing added glycolate level $(0,0.2,5$, and $10 \mathrm{~g} / \mathrm{L})$. Values preceded by "<" are below the detectible level. Where an RSD is not provided, a single analysis was performed and is listed as the average. Where average results are not reported for a specific combination of analyte, glycolate level, and time interval, no analysis was performed. A reduced set of time intervals were investigated at the glycolate level of $0.2 \mathrm{~g} / \mathrm{L}$. A reduced set of analyses were performed for the 21 day analyses. Quadruplicate analyses were performed by ICP-ES, ICP-MS and PuTTA for the 14 day and 35 day time intervals for glycolate levels of 0 and $10 \mathrm{~g} / \mathrm{L}$. Appendix A contains results for the individual samples, including results for analytes not reported in the summary tables.

Due to an error in sample preparation, the IC anion, TIC/TOC, and free hydroxide were not usable for the 21 day and 35 day time intervals. The 35 day sample for IC anions, TIC/TOC and free hydroxide was replaced by an alternate sample that did not have precisely the same history as the other 35 day samples. These analyses were taken for samples that were held at $50{ }^{\circ} \mathrm{C}$ for approximately 50 days and at $80{ }^{\circ} \mathrm{C}$ for approximately 7 days, and are reported in the column labeled " 35 days*".

The IC analysis for anions in the initial " 0 days" sample for the $10 \mathrm{~g} / \mathrm{L}$ glycolate case appears to be biased high by approximately $30 \%$ for all analytes with the exception of oxalate (includes glycolate, formate, nitrite, nitrate, sulfate and phosphate).

The time interval of 0 days can be considered as an initial measurement for each test condition. The 0 day contact times for the Tank $43 \mathrm{H}$ salt solution, the mixture of the Tank $38 \mathrm{H}$ salt solution and Tank $51 \mathrm{H}$ sludge, and the added glycolate (where applicable) was on the order of an hour or less at room temperature prior to filtration. Subsequent time intervals are used to track the concentration of each species at a given glycolate addition level.

A series of figures outline the soluble concentration of select species as a function of time and added glycolate concentration. Figure 3-1 contains the observed behavior of soluble aluminum, Figure 3-2 of iron, Figure 3-3 of uranium, and Figure 3-5 and Figure 3-6 of plutonium. The error bars included on the concentration and activity measurements are the reported $1 \sigma$ method uncertainties combined with the RSD. Although no error bars are included for the x-axis (time in days), the approximate uncertainty in timing is \pm 0.25 days. 
Table 3-1. Elemental composition analysis of the soluble portion of $2 \mathrm{H}$ Evaporator feed solution held in contact with sludge at $50^{\circ} \mathrm{C}$ : ICP-ES results

\begin{tabular}{|c|c|c|c|c|c|c|c|c|c|c|c|}
\hline \multirow{2}{*}{ analyte } & \multirow{2}{*}{$\begin{array}{c}\text { glycolate } \\
(\mathrm{g} / \mathrm{L})\end{array}$} & \multicolumn{2}{|c|}{0 days } & \multicolumn{2}{|c|}{7 days } & \multicolumn{2}{|c|}{14 days } & \multicolumn{2}{|c|}{21 days } & \multicolumn{2}{|c|}{35 days } \\
\hline & & average & RSD & average & RSD & average & RSD & average & RSD & average & RSD \\
\hline \multirow{4}{*}{$\begin{array}{c}\mathrm{Al} \\
(\mathrm{mg} / \mathrm{L})\end{array}$} & 0 & $9.21 \mathrm{E}+02$ & $0.5 \%$ & $9.12 \mathrm{E}+02$ & $0.5 \%$ & $9.11 \mathrm{E}+02$ & $0.3 \%$ & $9.25 \mathrm{E}+02$ & $0.7 \%$ & $9.57 \mathrm{E}+02$ & $0.5 \%$ \\
\hline & 0.2 & -- & & -- & & $9.22 \mathrm{E}+02$ & $0.1 \%$ & -- & & $9.61 \mathrm{E}+02$ & $0.5 \%$ \\
\hline & 5 & $9.18 \mathrm{E}+02$ & $0.2 \%$ & $9.29 \mathrm{E}+02$ & $1.5 \%$ & $9.05 \mathrm{E}+02$ & $0.6 \%$ & $9.22 \mathrm{E}+02$ & $0.2 \%$ & $9.43 \mathrm{E}+02$ & $0.4 \%$ \\
\hline & 10 & $9.24 \mathrm{E}+02$ & $0.3 \%$ & $9.15 \mathrm{E}+02$ & $0.4 \%$ & $9.04 \mathrm{E}+02$ & $0.6 \%$ & $9.15 \mathrm{E}+02$ & $1.2 \%$ & $9.31 \mathrm{E}+02$ & $0.7 \%$ \\
\hline \multirow{4}{*}{$\begin{array}{c}\text { B } \\
(\mathrm{mg} / \mathrm{L})\end{array}$} & 0 & $1.17 \mathrm{E}+02$ & $0.2 \%$ & $1.21 \mathrm{E}+02$ & $0.1 \%$ & $1.24 \mathrm{E}+02$ & $0.6 \%$ & $1.23 \mathrm{E}+02$ & $1.3 \%$ & $1.20 \mathrm{E}+02$ & $1.2 \%$ \\
\hline & 0.2 & -- & & -- & & $1.25 \mathrm{E}+02$ & $0.5 \%$ & -- & & $1.18 \mathrm{E}+02$ & $1.0 \%$ \\
\hline & 5 & $1.18 \mathrm{E}+02$ & $0.1 \%$ & $1.20 \mathrm{E}+02$ & $0.1 \%$ & $1.22 \mathrm{E}+02$ & $0.2 \%$ & $1.22 \mathrm{E}+02$ & $0.7 \%$ & $1.19 \mathrm{E}+02$ & $1.9 \%$ \\
\hline & 10 & $1.19 \mathrm{E}+02$ & $1.1 \%$ & $1.19 \mathrm{E}+02$ & $0.4 \%$ & $1.22 \mathrm{E}+02$ & $0.7 \%$ & $1.23 \mathrm{E}+02$ & $0.2 \%$ & $1.18 \mathrm{E}+02$ & $1.8 \%$ \\
\hline \multirow{4}{*}{$\begin{array}{c}\mathrm{Ca} \\
(\mathrm{mg} / \mathrm{L})\end{array}$} & 0 & $3.73 \mathrm{E}+00$ & $17 \%$ & $1.61 \mathrm{E}+00$ & $14 \%$ & $1.54 \mathrm{E}+00$ & $15 \%$ & $1.82 \mathrm{E}+00$ & $2.9 \%$ & $1.81 \mathrm{E}+00$ & $15 \%$ \\
\hline & 0.2 & -- & & -- & & $1.91 \mathrm{E}+00$ & $0.8 \%$ & -- & & $1.82 \mathrm{E}+00$ & $15 \%$ \\
\hline & 5 & $1.97 \mathrm{E}+00$ & $3.1 \%$ & $1.88 \mathrm{E}+00$ & $3.0 \%$ & $1.46 \mathrm{E}+00$ & $4.0 \%$ & $1.96 \mathrm{E}+00$ & $0.7 \%$ & $2.24 \mathrm{E}+00$ & $15 \%$ \\
\hline & 10 & $2.47 \mathrm{E}+00$ & $0.3 \%$ & $2.39 \mathrm{E}+00$ & $15 \%$ & $1.83 \mathrm{E}+00$ & $2.8 \%$ & $2.51 \mathrm{E}+00$ & $1.5 \%$ & $3.51 \mathrm{E}+00$ & $73 \%$ \\
\hline \multirow{4}{*}{$\begin{array}{c}\mathrm{Cr} \\
(\mathrm{mg} / \mathrm{L})\end{array}$} & 0 & $4.51 \mathrm{E}+01$ & $0.2 \%$ & $4.67 \mathrm{E}+01$ & $0.7 \%$ & $4.56 \mathrm{E}+01$ & $0.5 \%$ & $4.65 \mathrm{E}+01$ & $0.5 \%$ & $4.53 \mathrm{E}+01$ & $2.0 \%$ \\
\hline & 0.2 & -- & & -- & & $4.64 \mathrm{E}+01$ & $0.0 \%$ & -- & & $4.44 \mathrm{E}+01$ & $0.5 \%$ \\
\hline & 5 & $4.53 \mathrm{E}+01$ & $0.3 \%$ & $4.72 \mathrm{E}+01$ & $0.1 \%$ & $4.59 \mathrm{E}+01$ & $0.2 \%$ & $4.71 \mathrm{E}+01$ & $0.0 \%$ & $4.57 \mathrm{E}+01$ & $2.7 \%$ \\
\hline & 10 & $4.57 \mathrm{E}+01$ & $1.0 \%$ & $4.73 \mathrm{E}+01$ & $0.1 \%$ & $4.61 \mathrm{E}+01$ & $0.0 \%$ & $4.74 \mathrm{E}+01$ & $1.1 \%$ & $4.59 \mathrm{E}+01$ & $2.4 \%$ \\
\hline \multirow{4}{*}{$\begin{array}{c}\mathrm{Fe} \\
(\mathrm{mg} / \mathrm{L})\end{array}$} & 0 & $3.08 \mathrm{E}+01$ & $15 \%$ & $3.23 \mathrm{E}+00$ & $25 \%$ & $3.04 \mathrm{E}+00$ & $27 \%$ & $2.93 \mathrm{E}+00$ & $34.7 \%$ & $2.06 \mathrm{E}+00$ & $20 \%$ \\
\hline & 0.2 & -- & & -- & & $2.23 \mathrm{E}+00$ & $7.1 \%$ & -- & & $2.33 \mathrm{E}+00$ & $37 \%$ \\
\hline & 5 & $4.52 \mathrm{E}+00$ & $8.6 \%$ & $6.26 \mathrm{E}+00$ & $31 \%$ & $5.60 \mathrm{E}+00$ & $0.5 \%$ & $7.02 \mathrm{E}+00$ & $26 \%$ & $4.94 \mathrm{E}+00$ & $5.9 \%$ \\
\hline & 10 & $5.95 \mathrm{E}+00$ & $30 \%$ & $9.03 \mathrm{E}+00$ & $26 \%$ & $9.16 \mathrm{E}+00$ & $7.7 \%$ & $7.93 \mathrm{E}+00$ & $3.3 \%$ & $6.45 \mathrm{E}+00$ & $8.5 \%$ \\
\hline \multirow{4}{*}{$\begin{array}{c}\mathrm{K} \\
(\mathrm{mg} / \mathrm{L})\end{array}$} & 0 & $2.42 \mathrm{E}+02$ & $1.4 \%$ & $2.47 \mathrm{E}+02$ & $3.3 \%$ & $2.58 \mathrm{E}+02$ & $2.4 \%$ & $2.48 \mathrm{E}+02$ & $0.05 \%$ & $2.60 \mathrm{E}+02$ & $3.9 \%$ \\
\hline & 0.2 & -- & & -- & & $3.02 \mathrm{E}+02$ & $1.2 \%$ & -- & & $2.65 \mathrm{E}+02$ & $0.1 \%$ \\
\hline & 5 & $2.65 \mathrm{E}+02$ & $4.0 \%$ & $2.64 \mathrm{E}+02$ & $4.3 \%$ & $2.88 \mathrm{E}+02$ & $3.4 \%$ & $2.75 \mathrm{E}+02$ & $2.5 \%$ & $2.74 \mathrm{E}+02$ & $1.4 \%$ \\
\hline & 10 & $2.77 \mathrm{E}+02$ & $0.4 \%$ & $2.90 \mathrm{E}+02$ & $1.5 \%$ & $3.11 \mathrm{E}+02$ & $0.5 \%$ & $2.74 \mathrm{E}+02$ & $1.9 \%$ & $2.68 \mathrm{E}+02$ & $2.1 \%$ \\
\hline \multirow{4}{*}{$\begin{array}{c}\mathrm{Li} \\
(\mathrm{mg} / \mathrm{L})\end{array}$} & 0 & $5.07 \mathrm{E}+01$ & $0.5 \%$ & $5.10 \mathrm{E}+01$ & $0.3 \%$ & $5.07 \mathrm{E}+01$ & $0.02 \%$ & $5.05 \mathrm{E}+01$ & $0.7 \%$ & $5.19 \mathrm{E}+01$ & $0.4 \%$ \\
\hline & 0.2 & -- & & -- & & $5.09 \mathrm{E}+01$ & $0.4 \%$ & -- & & $5.25 \mathrm{E}+01$ & $0.7 \%$ \\
\hline & 5 & $4.99 \mathrm{E}+01$ & $0.4 \%$ & $5.08 \mathrm{E}+01$ & $0.05 \%$ & $5.07 \mathrm{E}+01$ & $0.4 \%$ & $5.00 \mathrm{E}+01$ & $0.3 \%$ & $5.17 \mathrm{E}+01$ & $0.5 \%$ \\
\hline & 10 & $5.02 \mathrm{E}+01$ & $0.2 \%$ & $5.08 \mathrm{E}+01$ & $0.4 \%$ & $4.98 \mathrm{E}+01$ & $0.1 \%$ & $5.01 \mathrm{E}+01$ & $0.9 \%$ & $5.13 \mathrm{E}+01$ & $0.4 \%$ \\
\hline \multirow{4}{*}{$\begin{array}{c}\mathrm{Na} \\
(\mathrm{mg} / \mathrm{L})\end{array}$} & 0 & $1.34 \mathrm{E}+05$ & $0.7 \%$ & $1.34 \mathrm{E}+05$ & $0.1 \%$ & $1.34 \mathrm{E}+05$ & $0.2 \%$ & $1.36 \mathrm{E}+05$ & $0.3 \%$ & $1.34 \mathrm{E}+05$ & $0.4 \%$ \\
\hline & 0.2 & -- & & -- & & $1.36 \mathrm{E}+05$ & $0.05 \%$ & -- & & $1.36 \mathrm{E}+05$ & $0.02 \%$ \\
\hline & 5 & $1.34 \mathrm{E}+05$ & $0.3 \%$ & $1.35 \mathrm{E}+05$ & $0.6 \%$ & $1.35 \mathrm{E}+05$ & $1.3 \%$ & $1.36 \mathrm{E}+05$ & $0.7 \%$ & $1.35 \mathrm{E}+05$ & $0.9 \%$ \\
\hline & 10 & $1.36 \mathrm{E}+05$ & $0.03 \%$ & $1.35 \mathrm{E}+05$ & $1.6 \%$ & $1.36 \mathrm{E}+05$ & $0.2 \%$ & $1.39 \mathrm{E}+05$ & $0.7 \%$ & $1.36 \mathrm{E}+05$ & $0.9 \%$ \\
\hline \multirow{4}{*}{$\begin{array}{c}\mathrm{P} \\
(\mathrm{mg} / \mathrm{L})\end{array}$} & 0 & $1.18 \mathrm{E}+02$ & $0.4 \%$ & $1.28 \mathrm{E}+02$ & $2.8 \%$ & $1.28 \mathrm{E}+02$ & $0.6 \%$ & $1.33 \mathrm{E}+02$ & $1.4 \%$ & $1.16 \mathrm{E}+02$ & $6.2 \%$ \\
\hline & 0.2 & -- & & -- & & $1.34 \mathrm{E}+02$ & $2.2 \%$ & -- & & $1.12 \mathrm{E}+02$ & $0.6 \%$ \\
\hline & 5 & $1.19 \mathrm{E}+02$ & $2.6 \%$ & $1.32 \mathrm{E}+02$ & $1.1 \%$ & $1.32 \mathrm{E}+02$ & $0.2 \%$ & $1.36 \mathrm{E}+02$ & $1.7 \%$ & $1.16 \mathrm{E}+02$ & $3.9 \%$ \\
\hline & 10 & $1.22 \mathrm{E}+02$ & $1.9 \%$ & $1.33 \mathrm{E}+02$ & $0.8 \%$ & $1.31 \mathrm{E}+02$ & $0.02 \%$ & $1.29 \mathrm{E}+02$ & $0.6 \%$ & $1.13 \mathrm{E}+02$ & $3.7 \%$ \\
\hline \multirow{4}{*}{$\begin{array}{c}\mathrm{S} \\
(\mathrm{mg} / \mathrm{L})\end{array}$} & 0 & $8.76 \mathrm{E}+02$ & $2.9 \%$ & $9.82 \mathrm{E}+02$ & $1.6 \%$ & $1.05 \mathrm{E}+03$ & $7.2 \%$ & $1.04 \mathrm{E}+03$ & $2.8 \%$ & $1.17 \mathrm{E}+03$ & $5.8 \%$ \\
\hline & 0.2 & -- & & -- & & $1.05 \mathrm{E}+03$ & $5.4 \%$ & -- & & $1.18 \mathrm{E}+03$ & $20 \%$ \\
\hline & 5 & $9.16 \mathrm{E}+02$ & $6.1 \%$ & $1.00 \mathrm{E}+03$ & $0.2 \%$ & $1.07 \mathrm{E}+03$ & $0.9 \%$ & $1.07 \mathrm{E}+03$ & $18 \%$ & $1.10 \mathrm{E}+03$ & $21 \%$ \\
\hline & 10 & $9.46 \mathrm{E}+02$ & $1.1 \%$ & $1.00 \mathrm{E}+03$ & $0.5 \%$ & $1.07 \mathrm{E}+03$ & $0.00 \%$ & $1.09 \mathrm{E}+03$ & $9.6 \%$ & $1.06 \mathrm{E}+03$ & $15 \%$ \\
\hline \multirow{4}{*}{$\begin{array}{c}\mathrm{Si} \\
(\mathrm{mg} / \mathrm{L})\end{array}$} & 0 & $1.97 \mathrm{E}+02$ & $0.8 \%$ & $9.08 \mathrm{E}+01$ & $1.0 \%$ & $7.68 \mathrm{E}+01$ & $2.1 \%$ & $7.02 \mathrm{E}+01$ & $1.9 \%$ & $5.50 \mathrm{E}+01$ & $0.9 \%$ \\
\hline & 0.2 & -- & & -- & & $7.75 \mathrm{E}+01$ & $0.9 \%$ & -- & & $5.47 \mathrm{E}+01$ & $1.1 \%$ \\
\hline & 5 & $1.99 \mathrm{E}+02$ & $0.4 \%$ & $9.15 \mathrm{E}+01$ & $1.1 \%$ & $7.90 \mathrm{E}+01$ & $3.2 \%$ & $6.92 \mathrm{E}+01$ & $0.3 \%$ & $5.35 \mathrm{E}+01$ & $2.6 \%$ \\
\hline & 10 & $2.18 \mathrm{E}+02$ & $2.9 \%$ & $8.98 \mathrm{E}+01$ & $0.3 \%$ & $8.67 \mathrm{E}+01$ & $16 \%$ & $6.71 \mathrm{E}+01$ & $1.5 \%$ & $5.29 \mathrm{E}+01$ & $2.6 \%$ \\
\hline & 0 & $6.46 \mathrm{E}+00$ & $3.6 \%$ & $5.15 \mathrm{E}+00$ & $1.8 \%$ & $5.48 \mathrm{E}+00$ & $0.2 \%$ & $5.11 \mathrm{E}+00$ & $2.7 \%$ & $4.95 \mathrm{E}+00$ & $4.4 \%$ \\
\hline & 0.2 & -- & & -- & & $5.78 \mathrm{E}+00$ & $3.3 \%$ & -- & & $4.71 \mathrm{E}+00$ & $0.7 \%$ \\
\hline$(\mathrm{mg} / \mathrm{L})$ & 5 & $4.98 \mathrm{E}+00$ & $1.4 \%$ & $5.49 \mathrm{E}+00$ & $2.7 \%$ & $5.57 \mathrm{E}+00$ & $1.7 \%$ & $5.33 \mathrm{E}+00$ & $2.6 \%$ & $5.36 \mathrm{E}+00$ & $23 \%$ \\
\hline & 10 & $5.05 \mathrm{E}+00$ & $0.8 \%$ & $5.63 \mathrm{E}+00$ & $1.3 \%$ & $5.62 \mathrm{E}+00$ & $0.9 \%$ & $5.35 \mathrm{E}+00$ & $2.4 \%$ & $5.20 \mathrm{E}+00$ & $13 \%$ \\
\hline
\end{tabular}


SRNL-STI-2013-00322

Revision 0

Table 3-2. Analysis of the soluble portion of $2 \mathrm{H}$ Evaporator feed solution held in contact with sludge at $50^{\circ} \mathrm{C}$ : ICP-MS and plutonium results

\begin{tabular}{|c|c|c|c|c|c|c|c|c|c|c|c|}
\hline \multirow{2}{*}{ analyte } & \multirow{2}{*}{$\begin{array}{c}\text { glycolate } \\
(\mathrm{g} / \mathrm{L})\end{array}$} & \multicolumn{2}{|c|}{0 days } & \multicolumn{2}{|c|}{7 days } & \multicolumn{2}{|c|}{14 days } & \multicolumn{2}{|c|}{21 days } & \multicolumn{2}{|c|}{35 days } \\
\hline & & average & RSD & average & RSD & average & RSD & average & RSD & average & RSD \\
\hline \multirow{4}{*}{$\begin{array}{c}\mathrm{Pb} \\
(\mathrm{mg} / \mathrm{L})\end{array}$} & 0 & $1.81 \mathrm{E}+00$ & $2.3 \%$ & $2.76 \mathrm{E}-01$ & $11 \%$ & $2.40 \mathrm{E}-01$ & $3.4 \%$ & $2.86 \mathrm{E}-01$ & $13 \%$ & $2.77 \mathrm{E}-01$ & $8.2 \%$ \\
\hline & 0.2 & -- & & -- & & $3.11 \mathrm{E}-01$ & $19 \%$ & -- & & $2.98 \mathrm{E}-01$ & $1.50 \%$ \\
\hline & 5 & $1.5 \mathrm{E}+00$ & $64 \%$ & $2.40 \mathrm{E}-01$ & $1.4 \%$ & 2.03E-01 & $1.8 \%$ & $2.47 \mathrm{E}-01$ & $0.7 \%$ & $1.4 \mathrm{E}+00$ & $160 \%$ \\
\hline & 10 & $6.37 \mathrm{E}-01$ & $2.1 \%$ & $2.80 \mathrm{E}-01$ & $3.8 \%$ & $1.90 \mathrm{E}-01$ & $11 \%$ & $2.68 \mathrm{E}-01$ & $3.0 \%$ & $4.88 \mathrm{E}-01$ & $92 \%$ \\
\hline \multirow{4}{*}{$\begin{array}{c}\mathrm{W} \\
(\mathrm{mg} / \mathrm{L})\end{array}$} & 0 & $1.09 \mathrm{E}+00$ & $4.5 \%$ & 8.62E-01 & $0.4 \%$ & $9.24 \mathrm{E}-01$ & $5.6 \%$ & $9.96 \mathrm{E}-01$ & $11 \%$ & $9.82 \mathrm{E}-01$ & $5.8 \%$ \\
\hline & 0.2 & -- & & -- & & $8.85 \mathrm{E}-01$ & $1.9 \%$ & -- & & $9.14 \mathrm{E}-01$ & $4.6 \%$ \\
\hline & 5 & $9.89 \mathrm{E}-01$ & $8.7 \%$ & 8.33E-01 & $2.9 \%$ & $9.82 \mathrm{E}-01$ & $6.2 \%$ & $9.32 \mathrm{E}-01$ & $3.1 \%$ & $9.60 \mathrm{E}-01$ & $5.2 \%$ \\
\hline & 10 & $9.72 \mathrm{E}-01$ & $5.9 \%$ & 8.29E-01 & $0.2 \%$ & $8.95 \mathrm{E}-01$ & $4.8 \%$ & $9.22 \mathrm{E}-01$ & $3.5 \%$ & $1.00 \mathrm{E}+00$ & $12 \%$ \\
\hline \multirow{4}{*}{$\begin{array}{c}\mathrm{Rb} \\
(\mathrm{mg} / \mathrm{L})\end{array}$} & 0 & $1.29 \mathrm{E}+00$ & $7.1 \%$ & $6.29 \mathrm{E}-01$ & $8.0 \%$ & $5.88 \mathrm{E}-01$ & $1.7 \%$ & $6.65 \mathrm{E}-01$ & $8.1 \%$ & $6.19 \mathrm{E}-01$ & $5.4 \%$ \\
\hline & 0.2 & -- & & -- & & $6.08 \mathrm{E}-01$ & $3.7 \%$ & -- & & $6.29 \mathrm{E}-01$ & $1.5 \%$ \\
\hline & 5 & $1.2 \mathrm{E}+00$ & $44 \%$ & $5.99 \mathrm{E}-01$ & $10 \%$ & $5.79 \mathrm{E}-01$ & $1.9 \%$ & $6.08 \mathrm{E}-01$ & $2.6 \%$ & $6.37 \mathrm{E}-01$ & $6.7 \%$ \\
\hline & 10 & $9.21 \mathrm{E}-01$ & $15 \%$ & $6.81 \mathrm{E}-01$ & $12 \%$ & $5.84 \mathrm{E}-01$ & $2.1 \%$ & $6.60 \mathrm{E}-01$ & $0.4 \%$ & $6.19 \mathrm{E}-01$ & $2.7 \%$ \\
\hline \multirow{4}{*}{$\begin{array}{l}\text { Tc-99 } \\
(\mathrm{mg} / \mathrm{L})\end{array}$} & 0 & $9.08 \mathrm{E}-01$ & $12 \%$ & $8.75 \mathrm{E}-01$ & $8.4 \%$ & $9.02 \mathrm{E}-01$ & $0.8 \%$ & $9.41 \mathrm{E}-01$ & $1.3 \%$ & $9.69 \mathrm{E}-01$ & $2.0 \%$ \\
\hline & 0.2 & -- & & -- & & $8.46 \mathrm{E}-01$ & $2.4 \%$ & -- & & $9.03 \mathrm{E}-01$ & $0.7 \%$ \\
\hline & 5 & $1.07 \mathrm{E}+00$ & $8.8 \%$ & $9.43 \mathrm{E}-01$ & $2.8 \%$ & $9.18 \mathrm{E}-01$ & $2.2 \%$ & $9.26 \mathrm{E}-01$ & $3.4 \%$ & $9.54 \mathrm{E}-01$ & $8.3 \%$ \\
\hline & 10 & $1.10 \mathrm{E}+00$ & $19 \%$ & $9.43 \mathrm{E}-01$ & $1.6 \%$ & $9.66 \mathrm{E}-01$ & $4.9 \%$ & $1.02 \mathrm{E}+00$ & $1.8 \%$ & $9.78 \mathrm{E}-01$ & $5.3 \%$ \\
\hline \multirow{4}{*}{$\begin{array}{c}\mathrm{U} \\
(\mathrm{mg} / \mathrm{L})\end{array}$} & 0 & $5.49 \mathrm{E}+01$ & $2.4 \%$ & $2.60 \mathrm{E}+01$ & $0.4 \%$ & $1.98 \mathrm{E}+01$ & $1.1 \%$ & $1.70 \mathrm{E}+01$ & $0.2 \%$ & $1.28 \mathrm{E}+01$ & $2.2 \%$ \\
\hline & 0.2 & -- & & -- & & $2.09 \mathrm{E}+01$ & $0.1 \%$ & -- & & $1.26 \mathrm{E}+01$ & $1.9 \%$ \\
\hline & 5 & $5.52 \mathrm{E}+01$ & $0.4 \%$ & $3.16 \mathrm{E}+01$ & $0.1 \%$ & $2.37 \mathrm{E}+01$ & $0.5 \%$ & $1.97 \mathrm{E}+01$ & $2.3 \%$ & $1.44 \mathrm{E}+01$ & $1.9 \%$ \\
\hline & 10 & $5.31 \mathrm{E}+01$ & $2.0 \%$ & $3.23 \mathrm{E}+01$ & $0.04 \%$ & $2.27 \mathrm{E}+01$ & $0.8 \%$ & $1.89 \mathrm{E}+01$ & $1.0 \%$ & $1.40 \mathrm{E}+01$ & $1.8 \%$ \\
\hline \multirow{4}{*}{$\begin{array}{c}\mathrm{Pu}-238 \\
(\mathrm{dpm} / \mathrm{mL})\end{array}$} & 0 & $2.16 \mathrm{E}+04$ & $4.8 \%$ & $9.19 \mathrm{E}+03$ & $1.8 \%$ & $7.49 \mathrm{E}+03$ & $10 \%$ & $7.27 \mathrm{E}+03$ & $1.3 \%$ & $6.88 \mathrm{E}+03$ & $15 \%$ \\
\hline & 0.2 & -- & & -- & & $6.87 \mathrm{E}+03$ & $5.8 \%$ & -- & & $6.03 \mathrm{E}+03$ & $14 \%$ \\
\hline & 5 & $2.12 \mathrm{E}+04$ & $0.3 \%$ & $5.74 \mathrm{E}+03$ & $7.9 \%$ & $1.64 \mathrm{E}+03$ & $21 \%$ & $1.12 \mathrm{E}+03$ & $8.2 \%$ & $1.28 \mathrm{E}+03$ & $41 \%$ \\
\hline & 10 & $2.14 \mathrm{E}+04$ & $8.7 \%$ & $4.04 \mathrm{E}+03$ & $22.3 \%$ & $1.59 \mathrm{E}+03$ & $6.6 \%$ & $1.53 \mathrm{E}+03$ & $4.6 \%$ & $1.62 \mathrm{E}+03$ & $22 \%$ \\
\hline
\end{tabular}


SRNL-STI-2013-00322

Revision 0

Table 3-3. Analysis of the soluble portion of $2 \mathrm{H}$ Evaporator feed solution held in contact with sludge at $50^{\circ} \mathrm{C}$ : IC anions, $\mathrm{OH}^{-}$and TIC/TOC results

\begin{tabular}{|c|c|c|c|c|c|c|c|c|c|c|c|}
\hline \multirow{2}{*}{ analyte } & \multirow{2}{*}{$\begin{array}{c}\text { glycolate } \\
(\mathrm{g} / \mathrm{L})\end{array}$} & \multicolumn{2}{|c|}{0 days } & \multicolumn{2}{|c|}{7 days } & \multicolumn{2}{|c|}{14 days } & \multicolumn{2}{|c|}{21 days } & \multicolumn{2}{|c|}{35 days* } \\
\hline & & average & RSD & average & RSD & average & RSD & average & RSD & average & RSD \\
\hline \multirow{3}{*}{$\begin{array}{c}\mathrm{C}_{2} \mathrm{H}_{3} \mathrm{O}_{3}{ }^{-} \\
(\mathrm{mg} / \mathrm{L})\end{array}$} & 0 & $<5.14 \mathrm{E}+02$ & & $<1.13 \mathrm{E}+03$ & & $<9.64 \mathrm{E}+02$ & & -- & & $<5.46 \mathrm{E}+02$ & \\
\hline & 5 & $5.75 \mathrm{E}+03$ & & $4.41 \mathrm{E}+03$ & & $4.23 \mathrm{E}+03$ & & -- & & -- & \\
\hline & 10 & $1.55 \mathrm{E}+04$ & & $8.75 \mathrm{E}+03$ & & $8.45 \mathrm{E}+03$ & & -- & & $6.59 \mathrm{E}+03$ & \\
\hline \multirow{3}{*}{$\begin{array}{c}\mathrm{CHO}_{2}^{-} \\
(\mathrm{mg} / \mathrm{L})\end{array}$} & 0 & $1.54 \mathrm{E}+03$ & & $1.48 \mathrm{E}+03$ & & $1.47 \mathrm{E}+03$ & & -- & & $1.18 \mathrm{E}+03$ & \\
\hline & 5 & $1.45 \mathrm{E}+03$ & & $1.63 \mathrm{E}+03$ & & $1.73 \mathrm{E}+03$ & & -- & & -- & \\
\hline & 10 & $2.00 \mathrm{E}+03$ & & $1.78 \mathrm{E}+03$ & & $1.87 \mathrm{E}+03$ & & -- & & $3.80 \mathrm{E}+03$ & \\
\hline \multirow{3}{*}{$\begin{array}{c}\mathrm{C}_{2} \mathrm{O}_{4}{ }^{2-} \\
(\mathrm{mg} / \mathrm{L})\end{array}$} & 0 & $2.37 \mathrm{E}+02$ & & $2.59 \mathrm{E}+02$ & & $2.51 \mathrm{E}+02$ & & -- & & $4.04 \mathrm{E}+02$ & \\
\hline & 5 & $1.91 \mathrm{E}+02$ & & $3.33 \mathrm{E}+02$ & & $3.58 \mathrm{E}+02$ & & -- & & -- & \\
\hline & 10 & $1.78 \mathrm{E}+02$ & & $3.73 \mathrm{E}+02$ & & $3.51 \mathrm{E}+02$ & & -- & & $1.48 \mathrm{E}+03$ & \\
\hline \multirow{3}{*}{$\begin{array}{l}\mathrm{NO}_{2}{ }^{-} \\
(\mathrm{mg} / \mathrm{L})\end{array}$} & 0 & $7.21 \mathrm{E}+04$ & & $7.58 \mathrm{E}+04$ & & $7.07 \mathrm{E}+04$ & & -- & & $7.30 \mathrm{E}+04$ & \\
\hline & 5 & $6.72 \mathrm{E}+04$ & & $7.02 \mathrm{E}+04$ & & $6.97 \mathrm{E}+04$ & & -- & & -- & \\
\hline & 10 & $9.07 \mathrm{E}+04$ & & $7.05 \mathrm{E}+04$ & & $6.95 \mathrm{E}+04$ & & -- & & $7.17 \mathrm{E}+04$ & \\
\hline \multirow{3}{*}{$\begin{array}{l}\mathrm{NO}_{3}{ }^{-} \\
(\mathrm{mg} / \mathrm{L})\end{array}$} & 0 & $5.75 \mathrm{E}+04$ & & $5.47 \mathrm{E}+04$ & & $5.52 \mathrm{E}+04$ & & -- & & $5.42 \mathrm{E}+04$ & \\
\hline & 5 & $5.47 \mathrm{E}+04$ & & $5.50 \mathrm{E}+04$ & & $5.43 \mathrm{E}+04$ & & -- & & -- & \\
\hline & 10 & $7.20 \mathrm{E}+04$ & & $5.50 \mathrm{E}+04$ & & $5.44 \mathrm{E}+04$ & & -- & & $5.45 \mathrm{E}+04$ & \\
\hline \multirow{3}{*}{$\begin{array}{l}\mathrm{SO}_{4}{ }^{2-} \\
(\mathrm{mg} / \mathrm{L})\end{array}$} & 0 & $1.90 \mathrm{E}+03$ & & $2.07 \mathrm{E}+03$ & & $2.03 \mathrm{E}+03$ & & -- & & $1.99 \mathrm{E}+03$ & \\
\hline & 5 & $1.88 \mathrm{E}+03$ & & $1.93 \mathrm{E}+03$ & & $2.00 \mathrm{E}+03$ & & -- & & -- & \\
\hline & 10 & $2.50 \mathrm{E}+03$ & & $2.03 \mathrm{E}+03$ & & $1.99 \mathrm{E}+03$ & & -- & & $2.01 \mathrm{E}+03$ & \\
\hline \multirow{3}{*}{$\begin{array}{l}\mathrm{PO}_{4}{ }^{3-} \\
(\mathrm{mg} / \mathrm{L})\end{array}$} & 0 & $2.88 \mathrm{E}+02$ & & $3.04 \mathrm{E}+02$ & & $2.89 \mathrm{E}+02$ & & -- & & $2.95 \mathrm{E}+02$ & \\
\hline & 5 & $2.98 \mathrm{E}+02$ & & $2.91 \mathrm{E}+02$ & & $2.84 \mathrm{E}+02$ & & -- & & -- & \\
\hline & 10 & $3.78 \mathrm{E}+02$ & & $2.89 \mathrm{E}+02$ & & $2.77 \mathrm{E}+02$ & & -- & & $2.83 \mathrm{E}+02$ & \\
\hline \multirow{3}{*}{$\begin{array}{l}\mathrm{OH}^{-} \\
(\mathrm{M})\end{array}$} & 0 & $2.50 \mathrm{E}+00$ & & -- & & -- & & -- & & $2.51 \mathrm{E}+00$ & \\
\hline & 5 & $2.39 \mathrm{E}+00$ & & -- & & -- & & -- & & -- & \\
\hline & 10 & $3.19 \mathrm{E}+00$ & & -- & & -- & & -- & & $2.46 \mathrm{E}+00$ & \\
\hline \multirow{3}{*}{$\begin{array}{l}\mathrm{CO}_{3}{ }^{2-} \\
(\mathrm{mg} / \mathrm{L})\end{array}$} & 0 & $2.11 \mathrm{E}+04$ & & -- & & -- & & -- & & $2.47 \mathrm{E}+04$ & \\
\hline & 5 & $2.11 \mathrm{E}+04$ & & -- & & -- & & -- & & -- & \\
\hline & 10 & $2.77 \mathrm{E}+04$ & & -- & & -- & & -- & & $2.51 \mathrm{E}+04$ & \\
\hline \multirow{3}{*}{$\begin{array}{c}\text { TOC } \\
(\mathrm{mg} / \mathrm{L})\end{array}$} & 0 & $4.62 \mathrm{E}+02$ & & -- & & -- & & -- & & $5.90 \mathrm{E}+02$ & \\
\hline & 5 & $1.97 \mathrm{E}+03$ & & -- & & -- & & -- & & -- & \\
\hline & 10 & $4.74 \mathrm{E}+03$ & & -- & & -- & & -- & & $3.27 \mathrm{E}+03$ & \\
\hline
\end{tabular}

* See the report text for an explanation of the 35 day sample for IC anions, TIC/TOC and free hydroxide. 
SRNL-STI-2013-00322

Revision 0

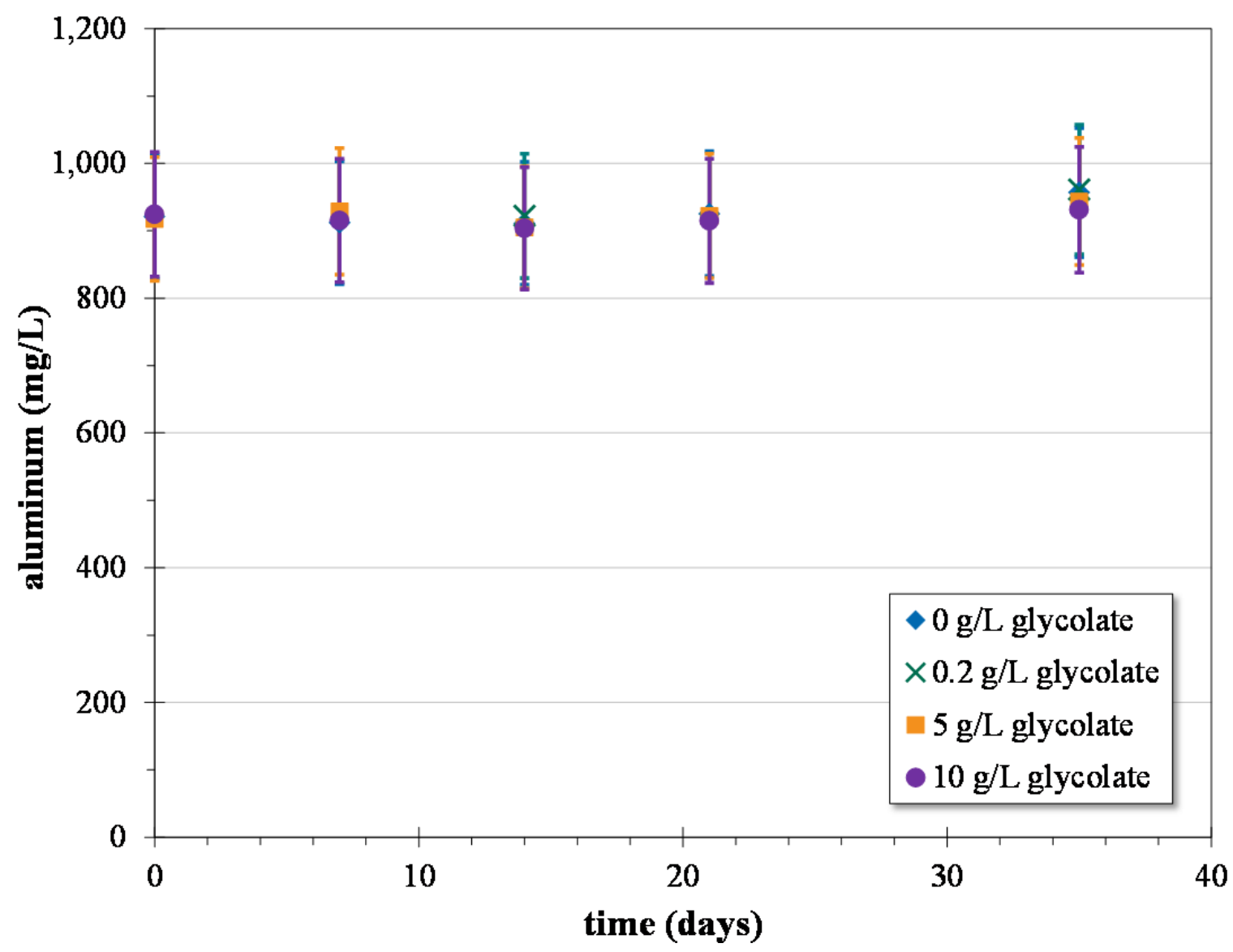

Figure 3-1. Influence of glycolate on soluble aluminum concentration in SRS Tank Farm actualwaste salt solution in contact with sludge at $50^{\circ} \mathrm{C}$

The most common outcome for the testing is that the soluble concentration of an analyte is stable with respect to time and does not show a dependence on the addition of glycolate. Figure 3-1 shows that the soluble aluminum concentration held steady within analytical uncertainty at approximately $920 \mathrm{mg} / \mathrm{L}$ for the 5-week period of equilibration at $50^{\circ} \mathrm{C}$. In addition, the soluble aluminum concentration was the same within analytical uncertainty for all four levels of glycolate addition. A sufficient amount of aluminum was contained in the sludge included in the equilibrating mixture so that an effect could be seen if aluminum dissolution was occurring. No significant aluminum dissolution or precipitation was noted from the supernate analysis, indicating that the mixture was likely already at its equilibrium solubility concentration of aluminum. From Table 3-1 through Table 3-3, the same trend represented by Figure 3-1 for aluminum can be noted for the soluble concentrations of boron, calcium, chromium, potassium, lithium, sodium, zinc, tungsten, technetium-99, and most of the inorganic ions. As discussed later, results for soluble calcium may not be reliable due to the appearance of a significant concentration of calcium in the reference solution analyzed along with the actual samples. 
SRNL-STI-2013-00322

Revision 0

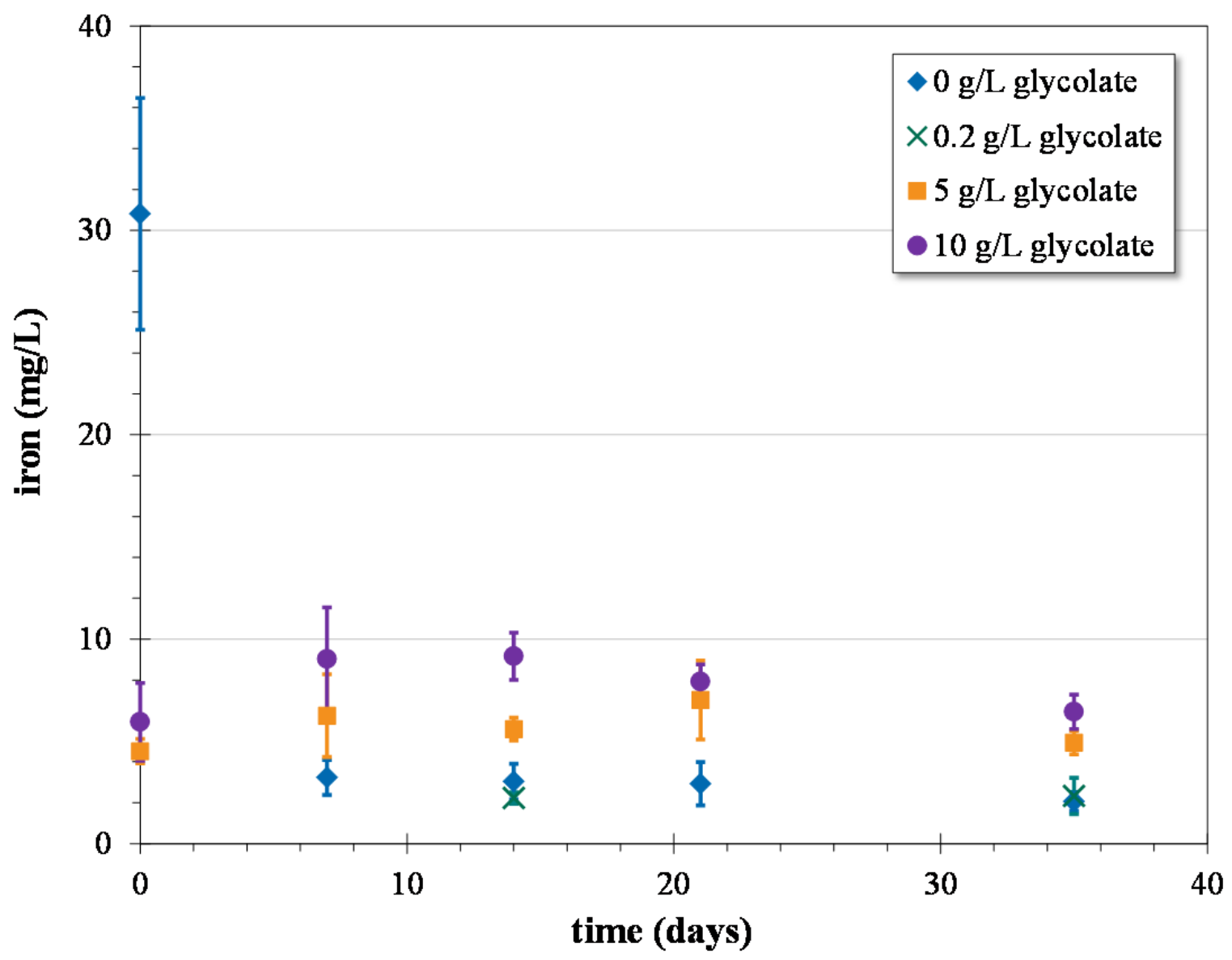

Figure 3-2. Influence of glycolate on soluble iron concentration in SRS Tank Farm actual-waste salt solution in contact with sludge at $50{ }^{\circ} \mathrm{C}$

Iron is the only sludge component that may have exhibited a higher solubility with the addition of glycolate. Figure 3-2 shows the soluble iron as functions of time and added glycolate concentration. With the exception of the initial sample analysis for $0 \mathrm{~g} / \mathrm{L}$ added glycolate, the iron solubility remained very low $(<10 \mathrm{mg} / \mathrm{L})$ throughout the testing. Throughout the equilibration period, the soluble iron concentrations remained about three-times higher in the salt solutions with $10 \mathrm{~g} / \mathrm{L}$ of added glycolate when compared to the solutions with $0 \mathrm{~g} / \mathrm{L}$ added glycolate. The $5 \mathrm{~g} / \mathrm{L}$ level of added glycolate exhibited soluble iron concentrations intermediate to those for the $0 \mathrm{~g} / \mathrm{L}$ and $10 \mathrm{~g} / \mathrm{L}$ levels of added glycolate.

There is considerable scatter in the iron data. Some of this may be due to a small fraction of the iron in the sludge passing through the 0.45 micron nylon filter and causing a significant impact on these trace measurements. Another factor is that many of the data are near the method detection limit of approximately $1.6 \mathrm{mg} / \mathrm{L}$. As will be discussed later, reference solutions analyzed with some sample sets had some results that measured iron in the rage of 2.3 to $3.4 \mathrm{mg} / \mathrm{L}$ even though those solutions should not have contained iron at those levels. 
SRNL-STI-2013-00322

Revision 0

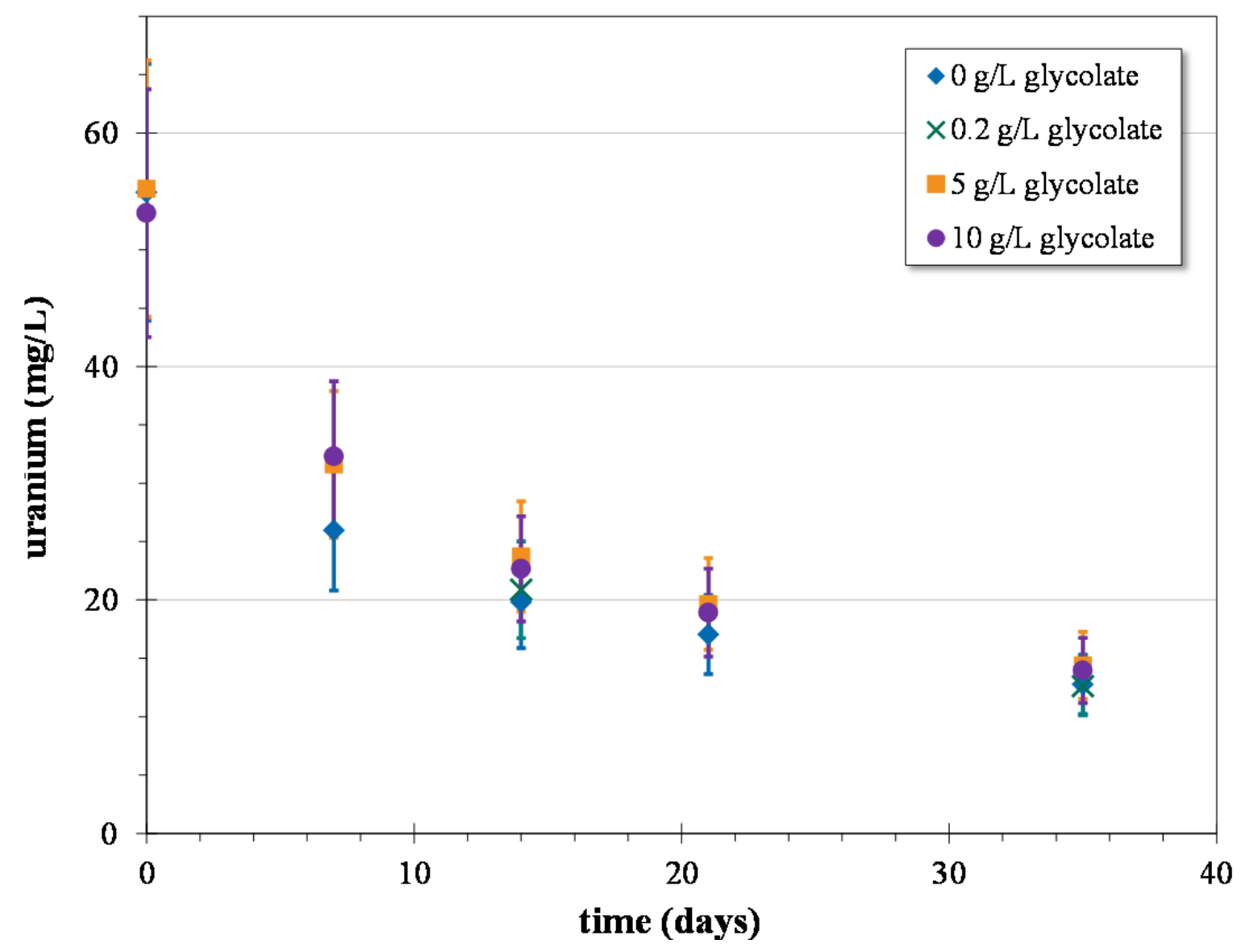

Figure 3-3. Influence of glycolate on soluble uranium concentration in SRS Tank Farm actualwaste salt solution in contact with sludge at $50^{\circ} \mathrm{C}$

The uranium concentrations in the unfiltered dip samples and VDS samples combined for this testing was 58 to $64 \mathrm{mg} / \mathrm{L}$ for Tank $43 \mathrm{H}$ and 58 to $93 \mathrm{mg} / \mathrm{L}$ for Tank $38 \mathrm{H}^{10,11,12}$ The initial filtered sample analysis showed a uranium concentration of approximately $54 \mathrm{mg} / \mathrm{L}$.

Figure 3-3 contains the trends for soluble uranium concentration with time and added glycolate concentration. Uranium concentration steadily decreases with time from approximately $54 \mathrm{mg} / \mathrm{L}$ in the initial samples ( 0 days) to approximately $13 \mathrm{mg} / \mathrm{L}$ after 35 days of contact with sludge at $50{ }^{\circ} \mathrm{C}$. This indicates that the original Tank $43 \mathrm{H}$ and $38 \mathrm{H}$ samples were supersaturated with respect to uranium at $50{ }^{\circ} \mathrm{C}$. In these tests, the added sludge and continuous agitation provided good mixing and particulate surface area for nucleation in excess of the typical conditions in Tanks $43 \mathrm{H}$ and $38 \mathrm{H}$, allowing for uranium to approach its equilibrium solubility faster than it does in the Tank Farm. The level of glycolate added to the samples did not influence the uranium solubility to an extent beyond the experimental uncertainty. Similar trends are noted for lead, silicon, and rubidium. 
The equilibrium soluble concentration of uranium and the equilibrium supernate activity of $\mathrm{Pu}-238$ were examined by plotting the measured values versus the inverse of the time. Because this analysis uses the inverse of the time, the data from the initial samples (0 days) cannot be not used.

Figure 3-4 shows the soluble uranium concentration as a function of inverse time held in contact with sludge at $50{ }^{\circ} \mathrm{C}$. Data for all glycolate concentrations are included and grouped together for this analysis. The y-intercept represents the value that the soluble uranium concentration asymptotically approaches at infinite time, which is the equilibrium concentration. Regardless of the presence of glycolate, the data show that the equilibrium solubility of uranium in contact with sludge at $50^{\circ} \mathrm{C}$ is approximately $6.6 \mathrm{mg} / \mathrm{L}$. For comparison, using the salt solution data in Table 3-3 in the uranium solubility models for solutions equilibrated for six months, the predicted uranium solubility is $6.7 \mathrm{mg} / \mathrm{L} .{ }^{16}$ This actual waste result matches the previously developed model much better than expected when considering the experimental uncertainties.

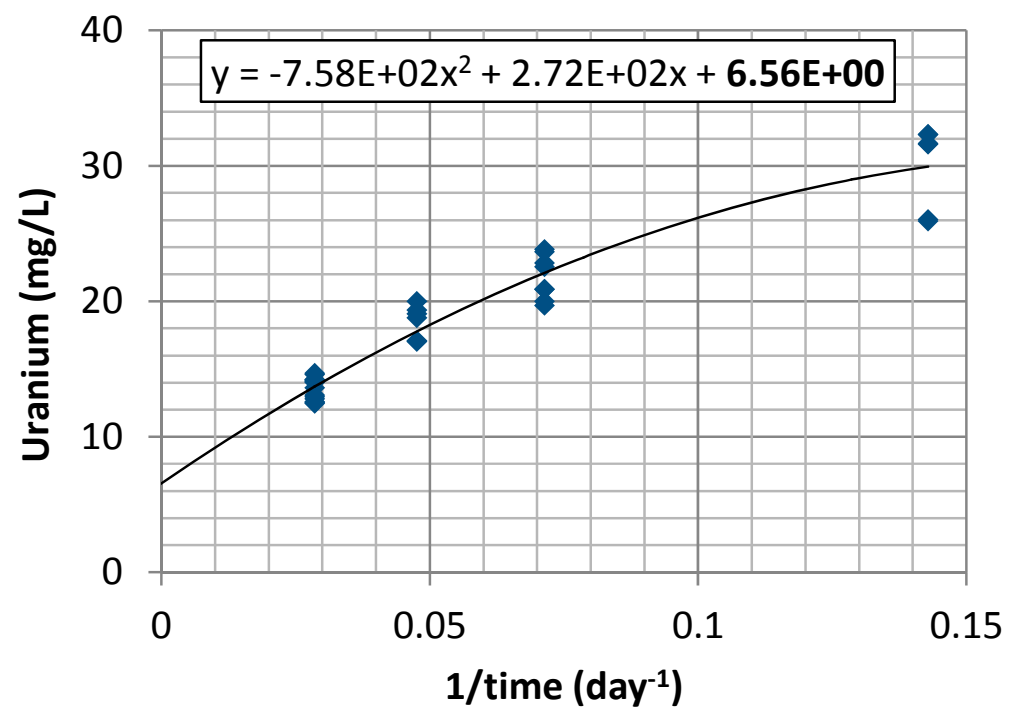

Figure 3-4. Evaluation of the equilibrium solubility of uranium in $2 \mathrm{H}$ Evaporator salt solution testing at $50^{\circ} \mathrm{C}$ 
SRNL-STI-2013-00322

Revision 0

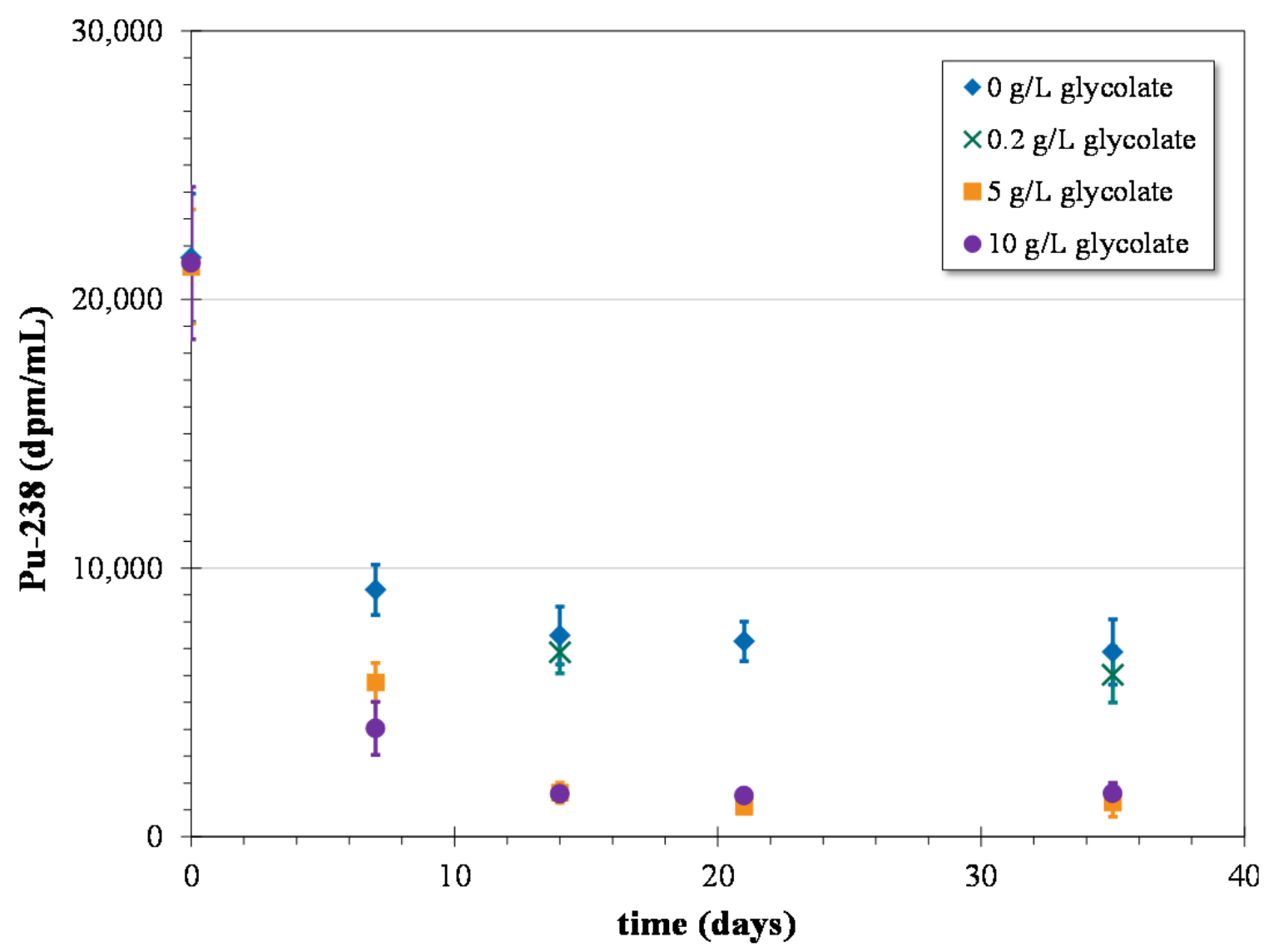

Figure 3-5. Influence of glycolate on soluble Pu-238 activity in SRS Tank Farm actual-waste salt solution in contact with sludge at $50^{\circ} \mathrm{C}$

From Figure 3-5, it is clear that plutonium was also supersaturated at $50{ }^{\circ} \mathrm{C}$ in the Tank $43 \mathrm{H}$ and $38 \mathrm{H}$ material. Within the first seven days of testing, the soluble plutonium-238 activity dropped from around $21,000 \mathrm{dpm} / \mathrm{mL}$ to levels below $10,000 \mathrm{dpm} / \mathrm{mL}$. In contrast to the observed solubility for uranium, however, the soluble activity of plutonium-238 exhibited a relationship to the added glycolate concentration. Glycolate appeared to suppress the solubility of plutonium at these conditions, with the plutonium-238 activity over four-times lower for the $5 \mathrm{~g} / \mathrm{L}$ and $10 \mathrm{~g} / \mathrm{L}$ added glycolate levels than for the $0 \mathrm{~g} / \mathrm{L}$ and $0.2 \mathrm{~g} / \mathrm{L}$ added glycolate levels at equilibration times of 14 days and greater.

The equilibrium plutionium-238 activity for $0 \mathrm{~g} / \mathrm{L}$ and $0.2 \mathrm{~g} / \mathrm{L}$ are roughly in the range of 5000 to 7000 $\mathrm{dpm} / \mathrm{mL}$. With the inclusion of $5 \mathrm{~g} / \mathrm{L}$ and $10 \mathrm{~g} / \mathrm{L}$ glycolate, the soluble plutonium-238 activity seems to stabilize around approximately $1500 \mathrm{dpm} / \mathrm{mL}$ during the timeframe of this experiment. 
SRNL-STI-2013-00322

Revision 0

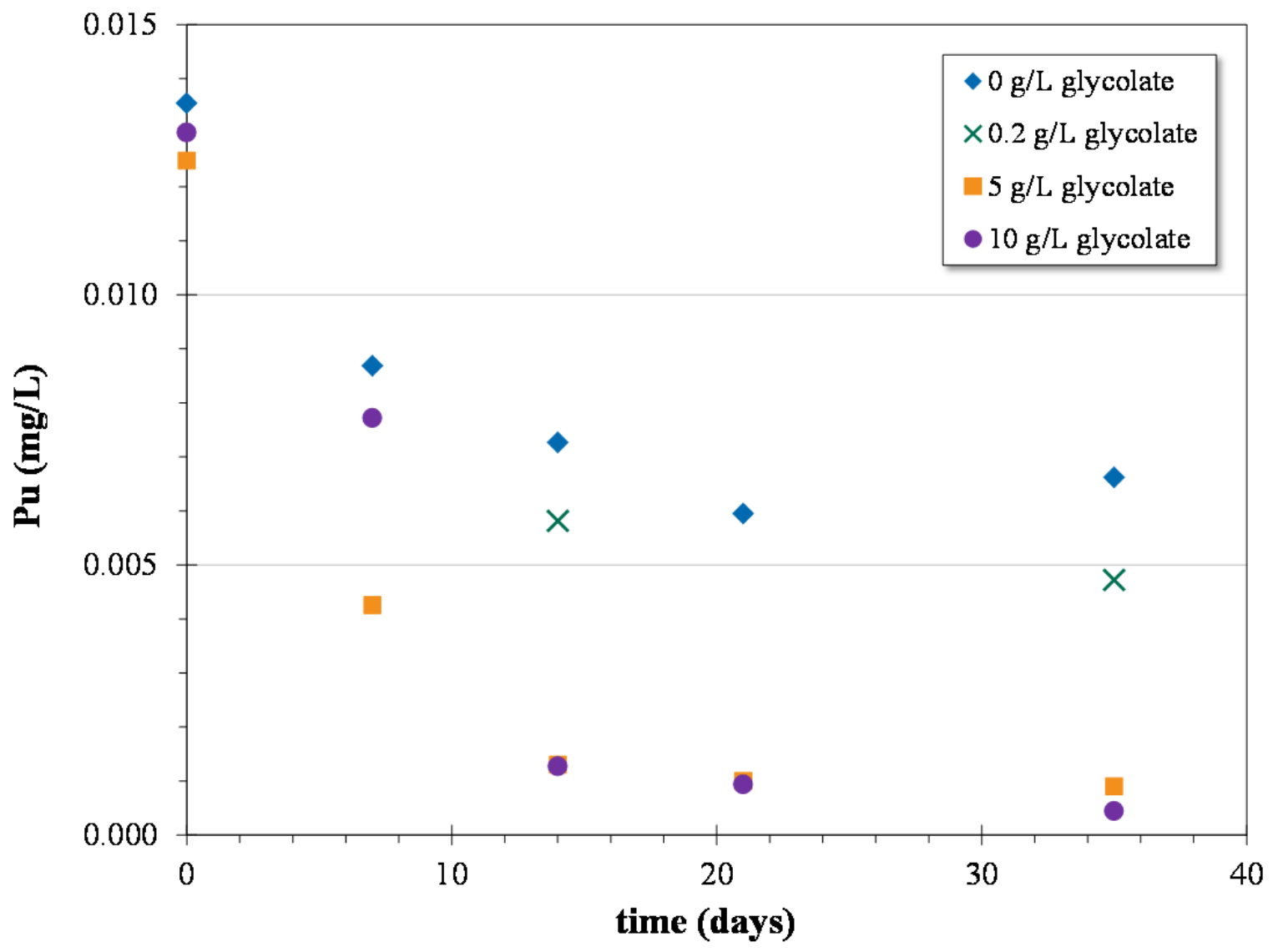

Figure 3-6. Influence of glycolate on soluble plutonium concentration in SRS Tank Farm actualwaste salt solution in contact with sludge at $50^{\circ} \mathrm{C}$

The plutionium-238 activity in Figure 3-5 is not a true solubility because the other isotopes of plutonium (i.e., plutionium-239 and plutionium-240) have a major impact on the concentration of plutonium on a mass basis. Making the assumption that the isotopic ratio of plutionium-239 to plutionium-240 are the same in the supernatant solution as they are in the Tank $51 \mathrm{H}$ sludge, the plutonium concentration was calculated on a mass basis and plotted in Figure 3-6. The same trends are evident when looking at the total plutonium mass that were noted for the $\mathrm{Pu}-238$ activity: plutonium appeared to be supersaturated in the initial salt solution and the addition of sodium glycolate appeared to suppress the solubility of plutonium. Because the $\mathrm{Pu}-239 / 240$ results had greater uncertainty than the $\mathrm{Pu}-238$ results, the uncertainty of the data in Figure 3-6 is greater than that for the data in Figure 3-5. 
Table 3-4. Analysis of reference solutions run with 0 day, 14 day and 35 day sample sets

\begin{tabular}{|c|c|c|c|c|c|c|c|c|c|c|}
\hline \multirow{2}{*}{ analyte } & \multicolumn{5}{|c|}{$0 \mathrm{~g} / \mathrm{L}$ glycolate (reference soluiton 1 ) } & \multicolumn{5}{|c|}{$10 \mathrm{~g} / \mathrm{L}$ glycolate (reference solution 2) } \\
\hline & cipe & previous $^{\mathrm{a}}$ & 0 days & 14 days & 35 days & recipe & previous $^{\mathrm{a}}$ & 0 days & 14 days & 35 days \\
\hline $\mathrm{Na}^{+}$ & $.51 \mathrm{E}+05$ & $1.31 \mathrm{E}+05$ & $1.49 \mathrm{E}+05$ & $1.50 \mathrm{E}+05$ & $1.50 \mathrm{E}+05$ & $.51 \mathrm{E}+05$ & $1.34 \mathrm{E}+05$ & $1.50 \mathrm{E}+05$ & $1.53 \mathrm{E}+05$ & $1.53 \mathrm{E}+05$ \\
\hline $\mathrm{K}^{+}$ & $\mathbf{0}$ & $6.18 \mathrm{E}+00$ & $<3.05 E+01$ & $<3.05 E+01$ & $3.37 \mathrm{E}+01$ & $\mathbf{0}$ & $6.37 \mathrm{E}+00$ & $5.30 \mathrm{E}+01$ & $5.82 \mathrm{E}+01$ & $<3.06 E+01$ \\
\hline $\mathrm{OH}^{-}$ & $61 E+04$ & $4.29 \mathrm{E}+04$ & $4.06 \mathrm{E}+04$ & -- & -- & $4.61 \mathrm{E}+04$ & $4.47 \mathrm{E}+04$ & $3.53 \mathrm{E}+04$ & -- & -- \\
\hline $\mathrm{NO}_{2}^{-}$ & 8.19E+04 & $8.60 \mathrm{E}+04$ & $8.03 \mathrm{E}+04$ & $8.16 \mathrm{E}+04$ & -- & $7.58 \mathrm{E}+04$ & $8.04 \mathrm{E}+04$ & $6.40 \mathrm{E}+04$ & $6.40 \mathrm{E}+04$ & -- \\
\hline $\mathrm{NO}_{3}^{-}$ & $6.57 E+04$ & $6.73 E+04$ & $6.54 \mathrm{E}+04$ & $6.35 \mathrm{E}+04$ & -- & $6.57 E+04$ & $6.80 \mathrm{E}+04$ & $5.36 \mathrm{E}+04$ & $5.33 \mathrm{E}+04$ & -- \\
\hline $\mathrm{CO}_{3}{ }^{2-}$ & $2.72 E+04$ & $2.34 \mathrm{E}+04$ & $2.78 \mathrm{E}+04$ & -- & $3.00 \mathrm{E}+04$ & $2.72 E+04$ & $2.36 \mathrm{E}+04$ & $2.35 \mathrm{E}+04$ & -- & $2.51 \mathrm{E}+04$ \\
\hline $\mathrm{AlO}_{2}^{-}$ & $2.24 \mathrm{E}+03$ & $2.22 \mathrm{E}+03$ & $2.31 \mathrm{E}+03$ & $2.34 \mathrm{E}+03$ & $2.30 \mathrm{E}+03$ & $2.24 \mathrm{E}+03$ & $2.19 \mathrm{E}+03$ & $2.34 \mathrm{E}+03$ & $2.36 \mathrm{E}+03$ & $2.31 \mathrm{E}+03$ \\
\hline $\mathrm{CHO}_{2}^{-}$ & $1.59 E+03$ & $1.63 \mathrm{E}+03$ & $1.65 \mathrm{E}+03$ & $1.61 \mathrm{E}+03$ & -- & $1.59 E+03$ & $1.85 \mathrm{E}+03$ & $1.37 \mathrm{E}+03$ & $1.37 \mathrm{E}+03$ & -- \\
\hline $\mathrm{SO}_{4}{ }^{2-}$ & $6.16 E+02$ & $5.73 E+02$ & $1.68 \mathrm{E}+03$ & $1.67 \mathrm{E}+03$ & -- & $6.16 \mathrm{E}+02$ & $5.72 \mathrm{E}+02$ & $1.37 \mathrm{E}+03$ & $1.50 \mathrm{E}+03$ & -- \\
\hline $\mathrm{PO}_{4}^{3-}$ & $1.30 \mathrm{E}+02$ & $1.67 \mathrm{E}+02$ & $3.82 \mathrm{E}+02$ & $3.41 \mathrm{E}+02$ & -- & $1.30 \mathrm{E}+02$ & $1.60 \mathrm{E}+02$ & $3.01 \mathrm{E}+02$ & $2.74 \mathrm{E}+02$ & -- \\
\hline $\mathrm{C}_{2} \mathrm{O}_{4}^{2-}$ & $1.67 E+02$ & $<1.00 E+03$ & $1.36 \mathrm{E}+02$ & $1.36 \mathrm{E}+02$ & -- & $1.67 E+02$ & $<1.00 E+03$ & $1.50 \mathrm{E}+02$ & $1.50 \mathrm{E}+02$ & -- \\
\hline $\mathrm{C}_{2} \mathrm{H}_{3} \mathrm{O}^{3-}$ & 0 & $<1.00 E+03$ & $<6.82 E+02$ & $<1.36 E+03$ & $<1.36 E+03$ & $1.00 \mathrm{E}+04$ & $9.88 \mathrm{E}+03$ & $8.86 \mathrm{E}+03$ & $7.44 \mathrm{E}+03$ & $7.77 \mathrm{E}+03$ \\
\hline TOC & $\mathbf{n} / \mathbf{a}$ & $5.22 \mathrm{E}+02$ & $3.92 \mathrm{E}+02$ & -- & $4.26 \mathrm{E}+02$ & $\mathbf{n} / \mathbf{a}$ & $3.01 \mathrm{E}+03$ & $2.82 \mathrm{E}+03$ & -- & $2.98 \mathrm{E}+03$ \\
\hline $\mathrm{Ca}$ & 0 & $1.63 \mathrm{E}+00$ & $4.10 \mathrm{E}+00$ & $3.32 \mathrm{E}+00$ & $3.63 \mathrm{E}+00$ & , & $1.81 \mathrm{E}+00$ & $4.88 \mathrm{E}+00$ & $4.11 \mathrm{E}+00$ & $4.34 \mathrm{E}+00$ \\
\hline $\mathrm{Fe}$ & $\mathbf{0}$ & $<1.00 E-01$ & $<1.58 E+00$ & $<1.58 E+00$ & $<1.58 E+00$ & 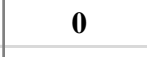 & $3.60 \mathrm{E}-01$ & $2.30 \mathrm{E}+00$ & $3.37 \mathrm{E}+00$ & $<1.58 E+00$ \\
\hline $\mathrm{Li}$ & 0 & $\mathrm{n} / \mathrm{a}$ & $<8.84 E-01$ & $9.48 \mathrm{E}-01$ & $<8.84 E-01$ & $\mathbf{0}$ & $\mathrm{n} / \mathrm{a}$ & $1.39 \mathrm{E}+00$ & $1.77 \mathrm{E}+00$ & $<8.87 E-01$ \\
\hline $\mathrm{Mg}$ & 0 & $\mathrm{n} / \mathrm{a}$ & $6.34 \mathrm{E}-01$ & $6.47 \mathrm{E}-01$ & $6.22 \mathrm{E}-01$ & 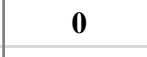 & $\mathrm{n} / \mathrm{a}$ & $1.13 \mathrm{E}+00$ & $1.20 \mathrm{E}+00$ & $1.11 \mathrm{E}+00$ \\
\hline $\mathrm{Mn}$ & 0 & $<1.00 E-01$ & $<9.87 E-01$ & $<9.87 E-01$ & $<9.87 E-01$ & $\mathbf{0}$ & $<1.00 E-01$ & $<9.90 E-01$ & $<9.90 E-01$ & $<9.90 E-01$ \\
\hline $\mathrm{Si}$ & $\mathbf{0}$ & $2.93 \mathrm{E}+00$ & $<5.10 E+00$ & $<5.10 E+00$ & $<5.10 E+00$ & $\mathbf{0}$ & $2.38 \mathrm{E}+00$ & $1.01 \mathrm{E}+01$ & $5.32 \mathrm{E}+00$ & $<5.12 E+00$ \\
\hline
\end{tabular}

Two reference solutions were submitted for ICP-ES, ICP-MS, IC, titration, and TIC/TOC analysis along with the 0 day, 14 day, and 35 day sample sets. These samples were submitted in an identical manner to the actual samples so that their identity was blind to the analysts. Table 3-4 contains the results for the reference solutions. The $0 \mathrm{~g} / \mathrm{L}$ and $10 \mathrm{~g} / \mathrm{L}$ glycolate reference solutions $(1$ and 2$)$ are the $0 \mathrm{~g} / \mathrm{L}$ and $10 \mathrm{~g} / \mathrm{L}$ glycolate Nominal Salt solutions for which the recipes and analysis are reported in Tables 1 and 4, respectively, of Reference 6 . The results in the columns labeled " 0 days", "14 days" and "35 days" are the results obtained by SRNL Analytical Development for the same material submitted along with the corresponding sample set.

The results for sodium and aluminum in the reference solutions match the recipe concentrations. The results for most anions were low by comparison to the reference solution recipes. This low bias is more prominent for the $10 \mathrm{~g} / \mathrm{L}$ glycolate reference material than for the $0 \mathrm{~g} / \mathrm{L}$ material. Glycolate and oxalate are included in the lower than expected analytical results. One possible factor contributing to a lower measured concentration of glycolate and oxalate is that 4 to 6 months had passed from the time the reference solutions were mixed to the time they were used in this analysis. In contrast, two anions, sulfate and phosphate, were typically measured at more than double their recipe and PSAL analysis concentrations.

Several analytes were measured in the reference samples even though they were not included in the original recipe. Potential causes for these observed analytes are 1) impurities in the chemicals used to make up the reference solutions, 2) impurities in the chemicals used for sample preparation and dilution, 
and 3) spurious analytical results. Causes 2 and 3 are of the most concern because they can be considered to apply to the actual samples and reference solutions equally. Of the additional analytes observed in the reference solutions, only calcium and iron were observed on the order of the measurements for the actual samples. Thus, calcium and iron results included in this report may be influenced by sample preparation impurities or otherwise spurious results. Levels of potassium, lithium and silicon measured in the actual samples were sufficiently high as to not be greatly influenced by any implication of the lower results for the reference solutions.

In summary, there is no anticipated impact of up to $10 \mathrm{~g} / \mathrm{L}$ of glycolate in DWPF recycle to the Tank Farm on tank waste component solubilities as investigated in this test. Uranium and plutonium appear to have been supersaturated in $2 \mathrm{H}$ evaporator feed solution mixture used for this testing. As a result, there was a reduction of soluble uranium and plutonium as a function of time. The change in soluble uranium concentration was independent of added glycolate concentration. The change in soluble plutonium content was dependent on the added glycolate concentration, with higher levels of glycolate $(5 \mathrm{~g} / \mathrm{L}$ and $10 \mathrm{~g} / \mathrm{L}$ ) appearing to suppress the plutonium solubility.

Most components were not influenced by glycolate during solubility tests. There was potentially a slight increase in soluble iron with added glycolate, but the soluble iron concentration remained so low (on the order of $10 \mathrm{mg} / \mathrm{L}$ ) as to not be able to impact the iron to fissile ratio in sludge. Prior to this testing, the hypothesized effect of added glycolate on plutonium was that the complexing nature of glycolate would increase the plutonium concentration in the supernate and provide a mechanism to separate plutonium from poisons in the sludge such as iron. However, the observed effect of glycolate on the soluble plutonium is the opposite of the hypothesized effect. Suppression of the already low soluble plutonium concentration in the supernate when glycolate is added is too insignificant to have a credible impact on the iron to fissile ratio in sludge. 
SRNL-STI-2013-00322

Revision 0

\subsection{Evaporator Scale Contact Tests}

The sodium aluminosilicate contact tests used material analogous to the soluble portions that resulted from the Tank Farm solubility tests and adds actual-waste $2 \mathrm{H}$-evaporator scale to simulate contact in the $2 \mathrm{H}$-evaporator system.

Table 4-1 contains results from the sodium aluminosilicate contact tests. The two major divisions of the $2 \mathrm{H}$-evaporator scale contact tests are tests that included $0 \mathrm{~g} / \mathrm{L}$ glycolate and tests that included $10 \mathrm{~g} / \mathrm{L}$ glycolate. The columns labeled "pre-contact" contains the results for a single analysis of the feed to the $2 \mathrm{H}$-evaporator scale contact tests. These feed materials had already been in contact with sludge and held at $50{ }^{\circ} \mathrm{C}$ for the desired amount of time. The pre-contact feed materials had yet to contact the $2 \mathrm{H}-$ evaporator scale. The columns labeled "post-contact" contain the result averages and RSDs for the characterization of soluble components from triplicate contact tests. The post-contact material resulted from contact with $2 \mathrm{H}$-evaporator scale at $80^{\circ} \mathrm{C}$ for a total of either 19 or 20 days. For the $10 \mathrm{~g} / \mathrm{L}$ level of added glycolate, the glycolate measured in the pre- and post-contact samples were both approximately 6.4 $\mathrm{g} / \mathrm{L}$.

Three main types of effects were observed for all components other than plutonium-238. These three effects are 1) no change, 2) an increase in soluble concentration, and 3) a decrease in soluble concentration, and are all independent of the level of added glycolate.

The majority of components did not have a significant change in pre-contact and post-contact concentrations for both $0 \mathrm{~g} / \mathrm{L}$ and $10 \mathrm{~g} / \mathrm{L}$ of added glycolate. This was seen for aluminum, boron, chromium, lithium, sodium, sulfur, zinc, sulfate, and hydroxide.

For a significant fraction of the components, there was an increase in the concentration of the component between the pre-contact and post-contact measurements for both $0 \mathrm{~g} / \mathrm{L}$ and $10 \mathrm{~g} / \mathrm{L}$ of added glycolate. This corresponds to the dissolution or leaching of components from the $2 \mathrm{H}$-evaporator pot scale. This effect, however, was the same for both $0 \mathrm{~g} / \mathrm{L}$ and $10 \mathrm{~g} / \mathrm{L}$ of added glycolate and thus is independent of glycolate content. This was seen for calcium, mercury, potassium, magnesium, phosphorous, uranium, formate, oxalate, nitrate, nitrite, phosphate, carbonate, and TOC.

For some components, there was a decrease in the concentration of the component between the precontact and post-contact measurements for both $0 \mathrm{~g} / \mathrm{L}$ and $10 \mathrm{~g} / \mathrm{L}$ of added glycolate. This corresponds to the sorption or precipitation of components onto the $2 \mathrm{H}$-evaporator pot scale. This effect, however, was the same for both $0 \mathrm{~g} / \mathrm{L}$ and $10 \mathrm{~g} / \mathrm{L}$ of added glycolate and thus is independent of glycolate content. This was typically a very minor effect and was seen for iron, silicon, and technetium-99.

For plutonium-238, the pre-contact starting conditions differed for the $0 \mathrm{~g} / \mathrm{L}$ and $10 \mathrm{~g} / \mathrm{L}$ added glycolate levels. This difference is expected based on the tests from the previous section. The post contact levels of soluble plutonium-238 were decreased for both the $0 \mathrm{~g} / \mathrm{L}$ and $10 \mathrm{~g} / \mathrm{L}$ added glycolate levels, indicating that sorption or precipitation of plutonium is taking place. The final soluble activity of plutonium-238 differ slightly between the two levels of added glycolate.

In summary, the inclusion of glycolate did not change the dissolution of or sorption onto actual-waste $2 \mathrm{H}-$ evaporator pot scale to an extent that will impact Tank Farm storage and concentration. The effects that were noted involved dissolution of components from evaporator scale and precipitation of components onto evaporator scale that were independent of the level of added glycolate. 
Table 4-1. Results from testing of sodium aluminosilicate evaporator scale contact with solutions that have contacted sludge, where 0 and $10 \mathrm{~g} / \mathrm{L}$ glycolate ion are present

\begin{tabular}{|c|c|c|c|c|c|c|c|}
\hline \multicolumn{2}{|c|}{ Glycolate: } & \multicolumn{3}{|c|}{$0 \mathrm{~g} / \mathrm{L}$} & \multicolumn{3}{|c|}{$10 \mathrm{~g} / \mathrm{L}$} \\
\hline \multirow{2}{*}{ analyte } & \multirow{2}{*}{ units } & \multirow{2}{*}{ pre-contact } & \multicolumn{2}{|c|}{ post-contact } & \multirow{2}{*}{ pre-contact } & \multicolumn{2}{|c|}{ post-contact } \\
\hline & & & average & RSD & & average & RSD \\
\hline $\mathrm{Al}$ & $\mathrm{mg} / \mathrm{L}$ & $1.33 \mathrm{E}+03$ & $1.29 \mathrm{E}+03$ & $6.6 \%$ & $1.26 \mathrm{E}+03$ & $1.35 \mathrm{E}+03$ & $11.9 \%$ \\
\hline $\mathrm{B}$ & $\mathrm{mg} / \mathrm{L}$ & $1.16 \mathrm{E}+02$ & $1.18 \mathrm{E}+02$ & $3.0 \%$ & $1.12 \mathrm{E}+02$ & $1.23 \mathrm{E}+02$ & $6.1 \%$ \\
\hline $\mathrm{Ca}$ & $\mathrm{mg} / \mathrm{L}$ & $9.78 \mathrm{E}+00$ & $1.41 \mathrm{E}+01$ & $25.8 \%$ & $1.24 \mathrm{E}+01$ & $1.72 \mathrm{E}+01$ & $10.7 \%$ \\
\hline $\mathrm{Cr}$ & $\mathrm{mg} / \mathrm{L}$ & $4.78 \mathrm{E}+01$ & $4.66 \mathrm{E}+01$ & $4.5 \%$ & $4.78 \mathrm{E}+01$ & $5.03 \mathrm{E}+01$ & $2.8 \%$ \\
\hline $\mathrm{Fe}$ & $\mathrm{mg} / \mathrm{L}$ & $6.71 \mathrm{E}+00$ & $\leq 1.41 \mathrm{E}+00^{\mathrm{a}}$ & -- & $3.17 \mathrm{E}+00$ & $\leq 2.48 \mathrm{E}+00^{\mathrm{a}}$ & -- \\
\hline $\mathrm{Hg}$ & $\mathrm{mg} / \mathrm{L}$ & $2.19 \mathrm{E}+02$ & $3.47 \mathrm{E}+02$ & $4.2 \%$ & $1.52 \mathrm{E}+02$ & $2.48 \mathrm{E}+02$ & $7.9 \%$ \\
\hline $\mathrm{K}$ & $\mathrm{mg} / \mathrm{L}$ & $2.74 \mathrm{E}+02$ & $3.39 \mathrm{E}+02$ & $9.8 \%$ & $2.71 \mathrm{E}+02$ & $3.86 \mathrm{E}+02$ & $10.5 \%$ \\
\hline $\mathrm{Li}$ & $\mathrm{mg} / \mathrm{L}$ & $4.55 \mathrm{E}+01$ & $4.49 \mathrm{E}+01$ & $2.6 \%$ & $4.36 \mathrm{E}+01$ & $4.63 \mathrm{E}+01$ & $5.9 \%$ \\
\hline $\mathrm{Mg}$ & $\mathrm{mg} / \mathrm{L}$ & $2.62 \mathrm{E}-01$ & $3.48 \mathrm{E}-01$ & $11.9 \%$ & 3.66E-01 & $5.67 \mathrm{E}-01$ & $33.0 \%$ \\
\hline $\mathrm{Na}$ & $\mathrm{mg} / \mathrm{L}$ & $1.33 \mathrm{E}+05$ & $1.30 \mathrm{E}+05$ & $3.0 \%$ & $1.30 \mathrm{E}+05$ & $1.39 \mathrm{E}+05$ & $6.0 \%$ \\
\hline $\mathrm{P}$ & $\mathrm{mg} / \mathrm{L}$ & $1.22 \mathrm{E}+02$ & $1.36 \mathrm{E}+02$ & $4.0 \%$ & $1.13 \mathrm{E}+02$ & $1.41 \mathrm{E}+02$ & $10.6 \%$ \\
\hline $\mathrm{S}$ & $\mathrm{mg} / \mathrm{L}$ & $<1.12 E+03$ & $1.12 \mathrm{E}+03$ & $14.0 \%$ & $<1.10 E+03$ & $1.05 \mathrm{E}+03$ & $23.0 \%$ \\
\hline $\mathrm{Si}$ & $\mathrm{mg} / \mathrm{L}$ & $4.08 \mathrm{E}+01$ & $3.46 \mathrm{E}+01$ & $1.6 \%$ & $4.08 \mathrm{E}+01$ & $3.45 \mathrm{E}+01$ & $2.4 \%$ \\
\hline $\mathrm{Zn}$ & $\mathrm{mg} / \mathrm{L}$ & $5.23 \mathrm{E}+00$ & $5.42 \mathrm{E}+00$ & $1.2 \%$ & $5.05 \mathrm{E}+00$ & $5.37 \mathrm{E}+00$ & $5.1 \%$ \\
\hline Tc-99 & $\mathrm{mg} / \mathrm{L}$ & $1.09 \mathrm{E}+00$ & 9.94E-01 & $10.0 \%$ & $1.12 \mathrm{E}+00$ & 8.67E-01 & $6.5 \%$ \\
\hline U-238 & $\mathrm{mg} / \mathrm{L}$ & $2.59 \mathrm{E}+00$ & $6.39 \mathrm{E}+00$ & $9.4 \%$ & $5.84 \mathrm{E}+00$ & $6.90 \mathrm{E}+00$ & $3.9 \%$ \\
\hline $\mathrm{Pu}-238$ & $\mathrm{dpm} / \mathrm{mL}$ & $4.05 \mathrm{E}+03$ & $4.38 \mathrm{E}+02^{b}$ & $23.2 \%$ & $7.27 \mathrm{E}+02$ & $2.84 \mathrm{E}+02^{\mathrm{c}}$ & $44.9 \%$ \\
\hline $\mathrm{C}_{2} \mathrm{H}_{3} \mathrm{O}_{3}^{-}$ & $\mathrm{mg} / \mathrm{L}$ & $<7.90 E+02$ & $<5.73 E+02$ & -- & $6.36 \mathrm{E}+03$ & $6.39 \mathrm{E}+03$ & $6.6 \%$ \\
\hline $\mathrm{CHO}_{2}^{-}$ & $\mathrm{mg} / \mathrm{L}$ & $1.42 \mathrm{E}+03$ & $1.48 \mathrm{E}+03$ & $1.6 \%$ & $3.71 \mathrm{E}+03$ & $4.50 \mathrm{E}+03$ & $6.6 \%$ \\
\hline $\mathrm{C}_{2} \mathrm{O}_{4}{ }^{2-}$ & $\mathrm{mg} / \mathrm{L}$ & $3.64 \mathrm{E}+02$ & $5.54 \mathrm{E}+02$ & $1.4 \%$ & $7.52 \mathrm{E}+02$ & $1.37 \mathrm{E}+03$ & $9.7 \%$ \\
\hline $\mathrm{NO}_{2}^{-}$ & $\mathrm{mg} / \mathrm{L}$ & $6.76 \mathrm{E}+04$ & $7.10 \mathrm{E}+04$ & $2.0 \%$ & $6.71 \mathrm{E}+04$ & $7.42 \mathrm{E}+04$ & $6.5 \%$ \\
\hline $\mathrm{NO}_{3}^{-}$ & $\mathrm{mg} / \mathrm{L}$ & $5.17 \mathrm{E}+04$ & $5.65 \mathrm{E}+04$ & $6.9 \%$ & $5.14 \mathrm{E}+04$ & $5.72 \mathrm{E}+04$ & $6.3 \%$ \\
\hline $\mathrm{SO}_{4}{ }^{2-}$ & $\mathrm{mg} / \mathrm{L}$ & $2.02 \mathrm{E}+03$ & $1.99 \mathrm{E}+03$ & $2.6 \%$ & $1.96 \mathrm{E}+03$ & $2.03 \mathrm{E}+03$ & $5.6 \%$ \\
\hline $\mathrm{PO}_{4}^{3-}$ & $\mathrm{mg} / \mathrm{L}$ & $2.69 \mathrm{E}+02$ & $2.94 \mathrm{E}+02$ & $2.5 \%$ & $2.66 \mathrm{E}+02$ & $3.13 \mathrm{E}+02$ & $6.1 \%$ \\
\hline $\mathrm{OH}$ & M & $2.17 \mathrm{E}+00$ & $2.12 \mathrm{E}+00$ & $3.1 \%$ & $2.07 \mathrm{E}+00$ & $2.08 \mathrm{E}+00$ & $6.7 \%$ \\
\hline $\mathrm{CO}_{3}{ }^{2-}$ & $\mathrm{mg} / \mathrm{L}$ & $2.23 \mathrm{E}+04$ & $2.37 \mathrm{E}+04$ & $2.2 \%$ & $2.48 \mathrm{E}+04$ & $2.89 \mathrm{E}+04$ & $7.7 \%$ \\
\hline TOC & $\mathrm{mg} / \mathrm{L}$ & $6.64 \mathrm{E}+02$ & $1.16 \mathrm{E}+03$ & $10.4 \%$ & $3.51 \mathrm{E}+03$ & $4.54 \mathrm{E}+03$ & $9.7 \%$ \\
\hline
\end{tabular}

${ }^{a} \mathrm{Fe}$ values combine measurements just above the detection limit with below detection limit values and thus have a high level of uncertainty.

${ }^{\mathrm{b}}$ post contact $\mathrm{Pu}-238$ values are near the detection limit and have a high level of uncertainty.

${ }^{c}$ post contact $\mathrm{Pu}-238$ values are near the detection limit and have a high level of uncertainty and include one measurement that is an "upper limit" value due to potential interferences. 
SRNL-STI-2013-00322

Revision 0

\subsection{Conclusions}

There is no anticipated impact of up to $10 \mathrm{~g} / \mathrm{L}$ of glycolate in DWPF recycle to the Tank Farm on tank waste component solubilities as investigated in this test.

Most components were not influenced by glycolate during solubility tests, including major components such as aluminum, sodium, and most salt anions. There was potentially a slight increase in soluble iron with added glycolate, but the soluble iron concentration remained so low (on the order of $10 \mathrm{mg} / \mathrm{L}$ ) as to not impact the iron to fissile ratio in sludge.

Uranium and plutonium appear to have been supersaturated in $2 \mathrm{H}$-evaporator feed solution mixture used for this testing. As a result, there was a reduction of soluble uranium and plutonium as a function of time. The change in soluble uranium concentration was independent of added glycolate concentration. The change in soluble plutonium content was dependent on the added glycolate concentration, with higher levels of glycolate $(5 \mathrm{~g} / \mathrm{L}$ and $10 \mathrm{~g} / \mathrm{L})$ appearing to suppress the plutonium solubility.

The inclusion of glycolate did not change the dissolution of or sorption onto actual-waste $2 \mathrm{H}$-evaporator pot scale to an extent that will impact Tank Farm storage and concentration. The effects that were noted involved dissolution of components from evaporator scale and precipitation of components onto evaporator scale that were independent of the level of added glycolate.

\subsection{Quality Assurance}

Data are recorded in the SRNL electronic laboratory notebook system as experiments A6583-00032-12, A6583-00032-15 and A6583-00032-16. This report received a technical review by means of Design Verification by Document Review. Requirements for performing reviews of technical reports and the extent of review are established in manual E7 2.60. SRNL documents the extent and type of review using the SRNL Technical Report Design Checklist contained in WSRC-IM-2002-00011, Rev. 2.

\subsection{Recommendations}

Results from other portions of glycolic acid flowsheet testing should be monitored to determine if they challenge any of the assumptions in this study. The major assumptions are that the maximum glycolate concentration sent to the Tank Farm will be $10 \mathrm{~g} / \mathrm{L}$ and that there are no major new organics beyond what is typical in SRS waste sent to the Tank Farm as a result of the breakdown or polymerization of glycolic acid. If it is confirmed through experimentation that a large amount of glycolate is contained in the DWPF recycle stream to the Tank Farm (i.e., $10 \mathrm{~g} / \mathrm{L}$ ), collecting further information on the decomposition of sodium glycolate within the SRS Tank Farm may be warranted (i.e., additional tests or waste sampling). 


\subsection{References}

${ }^{1}$ Lambert, D.P., B.R. Pickenheim, M.E. Stone, J.D. Newell, D.R. Best, "Glycolic - Formic Acid Flowsheet Final Report for Downselection Decision," SRNL-STI- 2010-00523, Rev. 1, March 2011.

${ }^{2}$ Lambert, D.P., M.E. Stone, J.D. Newell, D.R. Best, J.R. Zamecnik, "Glycolic-Nitric Acid Flowsheet Demonstration of the DWPF Chemical Process Cell with Sludge and Supernate Simulants," SRNLSTI-2012-00018, Rev. 1, August 2012.

${ }^{3} \mathrm{~K}$. Adu-Wusu, "Literature Review on Impact of Glycolate on the $2 \mathrm{H}$ Evaporator and the Effluent Treatment Facility (ETF)," SRNL-STI-2012-00132, Rev. 0, May 2012.

${ }^{4}$ T. L. Fellinger, "Downstream Impacts - Glycolate Behavior in Evaporator Feed Tanks and HLW Evaporators,” Task Technical Request, HLW-DWPF-TTR-2012-0014, Rev. 0, August 29, 2012.

${ }^{5}$ C. J. Martino, "Task Technical and Quality Assurance Plan for Impact of Glycolate on the $2 \mathrm{H}$ Evaporator System,” SRNL-RP-2012-00730, Rev. 0, December 2012.

${ }^{6}$ C. J. Martino, "Simulated Waste Testing of Glycolate Impacts on the 2H-Evaporator System," SRNLSTI-2013-00166, Rev. 0, August 2013.

${ }^{7}$ K. M. L. Taylor-Pashow, T. B. Peters, F. F. Fondeur, T. C. Shehee, A. L. Washington, "Determination of the Impact of Glycolate on ARP and MCU Operations," SRNL-STI-2012-00218, Rev. 1, December 2012.

${ }^{8}$ C. A. Nash, T. B. Peters, F. F. Fondeur, "Task Technical and Quality Assurance Plan for Glycolate and New Guanidine Solvent Testing for MCU," SRNL-RP-2014-00197, Rev. 0, March 2014.

${ }^{9}$ A. S. Choi, "Task Technical and Quality Assurance Plan for Updating OLI Database for Glycolate Species," SRNL-RP-2012-00478, Rev. 0, August 15, 2012.

${ }^{10}$ C. J. Martino, “Analysis of Tank 38H (HTF-38-11-137, 138) and Tank 43H (HTF-43-11-139, 140) Samples for Support of the Enrichment Control and Corrosion Control Programs," SRNL-3100-201200006, Rev. 0, January 17, 2012.

${ }^{11}$ C. J. Martino, "Analysis of Tank 38H (HTF-38-12-51, 52) and Tank 43H (HTF-43-12-53, 54) Samples for Support of the Enrichment Control and Corrosion Control Programs," SRNL-3100-2012-00076, Rev. 0, June 12, 2012.

${ }^{12}$ C. J. Martino, “Analysis of Tank 38H (HTF-38-12-103, 104) and Tank 43H (HTF-43-12-105, 106) Samples for Support of the Enrichment Control and Corrosion Control Programs," SRNL-3100-201200200, Rev. 0, November 26, 2012.

${ }^{13}$ J. M. Pareiz, C. L. Crawford and D. R. Click, "Sludge Batch 8 Qualification -Summary of Results From Radioactive CPC Simulation and Glass Analysis," SRNL-L3100-2013-00018, Rev. 0, February 7, 2012.

${ }^{14}$ M. S. Hay, J. M. Pareizs, D. R. Click, and D. P. Diprete, "Sludge Batch 8 Acceptance Evaluation: Radionuclide Concentrations in Tank 51 SB8 Qualification Sample Prepared at SRNL," SRNL-STI2012-00775, Rev. 0, January 2013.

${ }^{15}$ L. N. Oji, "Analysis of 2H-Evaporator Scale Pot Bottom Sample [HTF-13-11-28H], SRNL-STI-201300267, Rev. 0, July 2013.

${ }^{16}$ D. T. Hobbs, T. B. Edwards, and S. D. Fleischman, "Solubility of Plutonium and Uranium in Alkaline Salt Solutions (U),” WSRC-TR-93-056, February 12, 1993. 
SRNL-STI-2013-00322

Revision 0

Appendix A. Results for Replicate Analyses 
Table A-1. Analysis results of acid dilutions of sludge contact tests

\begin{tabular}{|c|c|c|c|c|c|c|c|c|c|c|c|c|c|c|}
\hline hold time (days) & 0 & 0 & Standard 1 & 0 & 0 & 0 & 0 & Standard 2 & 7 & 7 & 7 & 7 & 7 & 7 \\
\hline glycolate $(\mathrm{g} / \mathrm{L})$ & 0 & 0 & 0 & 5 & 5 & 10 & 10 & 10 & 0 & 0 & 5 & 5 & 10 & 10 \\
\hline $\mathrm{DF}(\mathrm{mL} / \mathrm{mL})$ & 10.11 & 10.32 & 12.70 & 10.90 & 10.44 & 10.95 & 12.13 & 12.70 & 10.75 & 10.73 & 9.49 & 9.55 & 8.83 & 9.22 \\
\hline LIMS numbers & 300303312 & 300303313 & 300303314 & 300303315 & 300303316 & 300303317 & 300303318 & 300303319 & 300303297 & 300303298 & 300303299 & 300303300 & 300303301 & 0303302 \\
\hline & 300303320 & 300303321 & & 300303322 & 300303323 & 300303324 & 300303325 & & 300303303 & 300303304 & 300303305 & 300303306 & 300303307 & 300303308 \\
\hline \multicolumn{15}{|c|}{ ICP-ES $(\mathrm{mg} / \mathrm{L})-$ nominal uncertanty $=10 \%$} \\
\hline $\mathrm{Ag}$ & $<1.13 \mathrm{E}+00$ & $<1.16 \mathrm{E}+00$ & $<1.42 \mathrm{E}+00$ & $<1.22 \mathrm{E}+00$ & $<1.17 \mathrm{E}+00$ & $<1.23 \mathrm{E}+00$ & $<1.36 \mathrm{E}+00$ & $<1.42 \mathrm{E}+00$ & $<1.20 \mathrm{E}+00$ & $<1.20 \mathrm{E}+00$ & $<1.06 \mathrm{E}+00$ & $<1.07 \mathrm{E}+00$ & $<9.89 \mathrm{E}-01$ & $<1.03 \mathrm{E}+00$ \\
\hline $\mathrm{Al}$ & $9.18 \mathrm{E}+02$ & $9.24 \mathrm{E}+02$ & $1.04 \mathrm{E}+03$ & $9.19 \mathrm{E}+02$ & $9.16 \mathrm{E}+02$ & $9.22 \mathrm{E}+02$ & $9.27 \mathrm{E}+02$ & $1.06 \mathrm{E}+03$ & $9.09 \mathrm{E}+02$ & $9.15 \mathrm{E}+02$ & $9.19 \mathrm{E}+02$ & $9.39 \mathrm{E}+02$ & $9.18 \mathrm{E}+02$ & $9.13 \mathrm{E}+02$ \\
\hline B & $1.17 \mathrm{E}+02$ & $1.18 \mathrm{E}+02$ & $<2.53 \mathrm{E}+00$ & $1.18 \mathrm{E}+02$ & $1.18 \mathrm{E}+02$ & $1.18 \mathrm{E}+02$ & $1.20 \mathrm{E}+02$ & $<2.53 \mathrm{E}+00$ & $1.21 \mathrm{E}+02$ & $1.21 \mathrm{E}+02$ & $1.21 \mathrm{E}+02$ & $1.20 \mathrm{E}+02$ & $1.19 \mathrm{E}+02$ & $1.20 \mathrm{E}+02$ \\
\hline $\mathrm{Ba}$ & $<5.36 \mathrm{E}-01$ & $<5.47 \mathrm{E}-01$ & $<6.73 \mathrm{E}-01$ & $<5.78 \mathrm{E}-01$ & $<5.53 \mathrm{E}-01$ & $<5.80 \mathrm{E}-01$ & $<6.43 \mathrm{E}-01$ & $<6.73 \mathrm{E}-01$ & $<5.70 \mathrm{E}-01$ & $<5.69 \mathrm{E}-01$ & $<5.03 \mathrm{E}-01$ & $<5.06 \mathrm{E}-01$ & $<4.68 \mathrm{E}-01$ & $<4.89 \mathrm{E}-01$ \\
\hline $\mathrm{Be}$ & $<1.21 \mathrm{E}-01$ & $<1.24 \mathrm{E}-01$ & $<1.52 \mathrm{E}-01$ & $<1.31 \mathrm{E}-01$ & $<1.25 \mathrm{E}-01$ & $<1.31 \mathrm{E}-01$ & $<1.46 \mathrm{E}-01$ & $<1.52 \mathrm{E}-01$ & $<1.29 \mathrm{E}-01$ & $<1.29 \mathrm{E}-01$ & $<1.14 \mathrm{E}-01$ & $<1.15 \mathrm{E}-01$ & $<1.06 \mathrm{E}-01$ & $<1.11 \mathrm{E}-01$ \\
\hline $\mathrm{Ca}$ & $3.29 \mathrm{E}+00$ & $4.18 \mathrm{E}+00$ & $4.06 \mathrm{E}+00$ & $2.02 \mathrm{E}+00$ & $1.93 \mathrm{E}+00$ & $2.46 \mathrm{E}+00$ & $2.47 \mathrm{E}+00$ & $4.82 \mathrm{E}+00$ & $1.45 \mathrm{E}+00$ & $1.77 \mathrm{E}+00$ & $1.84 \mathrm{E}+00$ & $1.92 \mathrm{E}+00$ & $2.13 \mathrm{E}+00$ & $2.65 \mathrm{E}+00$ \\
\hline $\mathrm{Cd}$ & $<1.45 \mathrm{E}+00$ & $<1.48 \mathrm{E}+00$ & $<1.82 \mathrm{E}+00$ & $<1.56 \mathrm{E}+00$ & $<1.49 \mathrm{E}+00$ & $<1.57 \mathrm{E}+00$ & $<1.73 \mathrm{E}+00$ & $<1.82 \mathrm{E}+00$ & $<1.54 \mathrm{E}+00$ & $<1.53 \mathrm{E}+00$ & $<1.36 \mathrm{E}+00$ & $<1.37 \mathrm{E}+00$ & $<1.26 \mathrm{E}+00$ & $<1.32 \mathrm{E}+00$ \\
\hline $\mathrm{Ce}$ & $<8.28 \mathrm{E}+00$ & $<8.45 \mathrm{E}+00$ & $<1.04 \mathrm{E}+01$ & $<8.93 \mathrm{E}+00$ & $<8.55 \mathrm{E}+00$ & $<8.97 \mathrm{E}+00$ & $<9.93 \mathrm{E}+00$ & $<1.04 \mathrm{E}+01$ & $<8.81 \mathrm{E}+00$ & $<8.79 \mathrm{E}+00$ & $<7.77 \mathrm{E}+00$ & $<7.82 \mathrm{E}+00$ & $<7.23 \mathrm{E}+00$ & $<7.55 \mathrm{E}+00$ \\
\hline Co & $<1.87 \mathrm{E}+00$ & $<1.91 \mathrm{E}+00$ & $<2.35 \mathrm{E}+00$ & $<2.02 \mathrm{E}+00$ & $<1.93 \mathrm{E}+00$ & $<2.03 \mathrm{E}+00$ & $<2.24 \mathrm{E}+00$ & $<2.35 \mathrm{E}+00$ & $<1.99 \mathrm{E}+00$ & $<1.99 \mathrm{E}+00$ & $<1.76 \mathrm{E}+00$ & $<1.77 \mathrm{E}+00$ & $<1.63 \mathrm{E}+00$ & $<1.71 \mathrm{E}+00$ \\
\hline $\mathrm{Cr}$ & $4.51 \mathrm{E}+01$ & $4.52 \mathrm{E}+01$ & $<2.83 \mathrm{E}+00$ & $4.54 \mathrm{E}+01$ & $4.52 \mathrm{E}+01$ & $4.53 \mathrm{E}+01$ & $4.60 \mathrm{E}+01$ & $<2.83 \mathrm{E}+00$ & $4.64 \mathrm{E}+01$ & $4.69 \mathrm{E}+01$ & $4.73 \mathrm{E}+01$ & $4.72 \mathrm{E}+01$ & $4.73 \mathrm{E}+01$ & $4.74 \mathrm{E}+01$ \\
\hline $\mathrm{Cu}$ & $<3.00 \mathrm{E}+00$ & $<3.06 \mathrm{E}+00$ & $<3.77 \mathrm{E}+00$ & $<3.24 \mathrm{E}+00$ & $<3.10 \mathrm{E}+00$ & $<3.25 \mathrm{E}+00$ & $<3.60 \mathrm{E}+00$ & $<3.77 \mathrm{E}+00$ & $<3.19 \mathrm{E}+00$ & $<3.19 \mathrm{E}+00$ & $<2.82 \mathrm{E}+00$ & $<2.84 \mathrm{E}+00$ & $<2.62 \mathrm{E}+00$ & $<2.74 \mathrm{E}+00$ \\
\hline $\mathrm{Fe}$ & $3.42 \mathrm{E}+01$ & $2.74 \mathrm{E}+01$ & $<1.56 \mathrm{E}+00$ & $4.24 \mathrm{E}+00$ & $4.79 \mathrm{E}+00$ & $4.68 \mathrm{E}+00$ & $7.23 \mathrm{E}+00$ & $2.27 \mathrm{E}+00$ & $3.80 \mathrm{E}+00$ & $2.67 \mathrm{E}+00$ & $4.90 \mathrm{E}+00$ & $7.61 \mathrm{E}+00$ & $7.36 \mathrm{E}+00$ & $1.07 \mathrm{E}+01$ \\
\hline $\mathrm{Gd}$ & $<2.40 \mathrm{E}+00$ & $<2.45 \mathrm{E}+00$ & $<3.01 \mathrm{E}+00$ & $<2.58 \mathrm{E}+00$ & $<2.47 \mathrm{E}+00$ & $<2.60 \mathrm{E}+00$ & $<2.87 \mathrm{E}+00$ & $<3.01 \mathrm{E}+00$ & $<2.55 \mathrm{E}+00$ & $<2.54 \mathrm{E}+00$ & $<2.25 \mathrm{E}+00$ & $<2.26 \mathrm{E}+00$ & $<2.09 \mathrm{E}+00$ & $<2.18 \mathrm{E}+00$ \\
\hline K & $2.40 \mathrm{E}+02$ & $2.45 \mathrm{E}+02$ & $<3.02 \mathrm{E}+01$ & $2.57 \mathrm{E}+02$ & $2.72 \mathrm{E}+02$ & $2.78 \mathrm{E}+02$ & $2.77 \mathrm{E}+02$ & $5.23 \mathrm{E}+01$ & $2.41 \mathrm{E}+02$ & $2.52 \mathrm{E}+02$ & -02 & & $2.87 \mathrm{E}+02$ & $3 \mathrm{E}+02$ \\
\hline $\mathrm{La}$ & $<1.27 \mathrm{E}+00$ & $<1.30 \mathrm{E}+00$ & $<1.60 \mathrm{E}+00$ & $<1.37 \mathrm{E}+00$ & $<1.32 \mathrm{E}+00$ & $<1.38 \mathrm{E}+00$ & $<1.53 \mathrm{E}+00$ & $<1.60 \mathrm{E}+00$ & $<1.35 \mathrm{E}+00$ & $<1.35 \mathrm{E}+00$ & $<1.20 \mathrm{E}+00$ & $<1.20 \mathrm{E}+00$ & $<1.11 \mathrm{E}+00$ & $<1.16 \mathrm{E}+00$ \\
\hline $\mathrm{Li}$ & $5.09 \mathrm{E}+01$ & $5.06 \mathrm{E}+01$ & $<8.76 \mathrm{E}-01$ & $4.97 \mathrm{E}+01$ & $5.00 \mathrm{E}+01$ & $03 \mathrm{E}+01$ & $5.01 \mathrm{E}+01$ & $\mathrm{E}+00$ & $11 \mathrm{E}+01$ & $5.09 \mathrm{E}+01$ & $5.08 \mathrm{E}+01$ & $5.08 \mathrm{E}+01$ & $5.07 \mathrm{E}+01$ & $E+01$ \\
\hline $\mathrm{Mg}$ & 2E-01 & $1.96 \mathrm{E}-01$ & -01 & $<1.09 \mathrm{E}-01$ & $<1.04 \mathrm{E}-01$ & $1.64 \mathrm{E}-01$ & $<1.21 \mathrm{E}-01$ & 500 & 1.02 & 01 & & 01 & 01 & E-01 \\
\hline $\mathrm{Mn}$ & $<7.7$ & $<7$ & $<9.7$ & $<8$ & $<8$ & 01 & 01 & -01 & $<1$. & $<1$ & & & 01 & +00 \\
\hline Mo & $<9.94 \mathrm{E}+00$ & $\mathrm{E}+01$ & $<1$. & $<1$ & $<1$ & $<1$ & +01 & +01 & -01 & $<1$ & 00 & +00 & +00 & +00 \\
\hline $\mathrm{Na}$ & $E+05$ & +05 & +05 & 05 & -05 & 05 & +05 & +05 & -05 & 05 & 05 & -05 & +05 & +05 \\
\hline $\mathrm{Ni}$ & $<2.09 \mathrm{E}+00$ & $<2.14 \mathrm{E}+00$ & $<2.63 \mathrm{E}+00$ & $<2.26 \mathrm{E}+00$ & $<2.16 \mathrm{E}+00$ & $<2.27 \mathrm{E}+00$ & $<2.51 \mathrm{E}+00$ & $<2.63 \mathrm{E}+00$ & $<2.23 \mathrm{E}+00$ & $<2.22 \mathrm{E}+00$ & $<1.9$ & $<1.9$ & $<1.83 \mathrm{E}+00$ & +00 \\
\hline $\mathrm{P}$ & $E+02$ & +02 & +02 & 02 & 02 & 2 & +02 & -02 & +02 & 02 & 02 & 02 & +02 & +02 \\
\hline $\mathrm{Pb}$ & $<8.27 \mathrm{E}+00$ & $<8.44 \mathrm{E}+00$ & $<1.04 \mathrm{E}+01$ & $<8.92 \mathrm{E}+00$ & $<8.54 \mathrm{E}+00$ & $<8.96 \mathrm{E}+00$ & $<9.92 \mathrm{E}+00$ & $<1.04 \mathrm{E}+01$ & $<4.96 \mathrm{E}+01$ & $<4.95 \mathrm{E}+01$ & $<4.38 \mathrm{E}+01$ & $<4.40 \mathrm{E}+01$ & $<4.07 \mathrm{E}+01$ & $<4.25 \mathrm{E}+01$ \\
\hline $\mathrm{S}$ & $8.95 \mathrm{E}+02$ & $8.58 \mathrm{E}+02$ & $<7.62 \mathrm{E}+02$ & $9.56 \mathrm{E}+02$ & $8.77 \mathrm{E}+02$ & $9.38 \mathrm{E}+02$ & $9.53 \mathrm{E}+02$ & $<7.62 \mathrm{E}+02$ & $9.71 \mathrm{E}+02$ & 9.93 & $1.01 \mathrm{E}+03$ & $1.00 \mathrm{E}+03$ & $9.97 \mathrm{E}+02$ & $1.00 \mathrm{E}+03$ \\
\hline $\mathrm{Sb}$ & $<3.49 \mathrm{E}+01$ & $<3.56 \mathrm{E}+01$ & $<4.38 \mathrm{E}+01$ & $<3.76 \mathrm{E}+01$ & $<3.60 \mathrm{E}+01$ & $<3.78 \mathrm{E}+01$ & $<4.18 \mathrm{E}+01$ & $<4.38 \mathrm{E}+01$ & $<3.71 \mathrm{E}+01$ & $<3.70 \mathrm{E}+01$ & $<3.28 \mathrm{E}+01$ & $<3.30 \mathrm{E}+01$ & $<3.05 \mathrm{E}+01$ & $<3.18 \mathrm{E}+01$ \\
\hline $\mathrm{Si}$ & $1.98 \mathrm{E}+02$ & $1.96 \mathrm{E}+02$ & $<5.05 \mathrm{E}+00$ & $2.00 \mathrm{E}+02$ & $1.98 \mathrm{E}+02$ & $2.22 \mathrm{E}+02$ & $2.13 \mathrm{E}+02$ & $9.94 \mathrm{E}+00$ & $9.14 \mathrm{E}+01$ & $9.01 \mathrm{E}+01$ & $9.22 \mathrm{E}+01$ & $9.08 \mathrm{E}+01$ & $9.00 \mathrm{E}+01$ & $8.96 \mathrm{E}+01$ \\
\hline $\mathrm{Sn}$ & $<1.19 \mathrm{E}+01$ & $<1.22 \mathrm{E}+01$ & $<1.50 \mathrm{E}+01$ & $<1.29 \mathrm{E}+01$ & $<1.23 \mathrm{E}+01$ & $<1.29 \mathrm{E}+01$ & $<1.43 \mathrm{E}+01$ & $<1.50 \mathrm{E}+01$ & $<1.59 \mathrm{E}+01$ & $<1.59 \mathrm{E}+01$ & $<1.40 \mathrm{E}+01$ & $<1.41 \mathrm{E}+01$ & $<1.31 \mathrm{E}+01$ & $<1.36 \mathrm{E}+01$ \\
\hline $\mathrm{Sr}$ & $<5.05 \mathrm{E}-02$ & $<5.16 \mathrm{E}-02$ & $<6.35 \mathrm{E}-02$ & $<5.45 \mathrm{E}-02$ & $<5.22 \mathrm{E}-02$ & $<5.48 \mathrm{E}-02$ & $<6.06 \mathrm{E}-02$ & $<6.35 \mathrm{E}-02$ & $<5.38 \mathrm{E}-02$ & $<5.37 \mathrm{E}-02$ & $<4.75 \mathrm{E}-02$ & $<4.78 \mathrm{E}-02$ & $<4.41 \mathrm{E}-02$ & $<4.61 \mathrm{E}-02$ \\
\hline Th & $<5.18 \mathrm{E}+00$ & $<5.28 \mathrm{E}+00$ & $<6.50 \mathrm{E}+00$ & $<5.58 \mathrm{E}+00$ & $<5.34 \mathrm{E}+00$ & $<5.61 \mathrm{E}+00$ & $<6.21 \mathrm{E}+00$ & $<6.50 \mathrm{E}+00$ & $<5.50 \mathrm{E}+00$ & $<5.49 \mathrm{E}+00$ & $<4.86 \mathrm{E}+00$ & $<4.89 \mathrm{E}+00$ & $<4.52 \mathrm{E}+00$ & $<4.72 \mathrm{E}+00$ \\
\hline $\mathrm{Ti}$ & $<5.86 \mathrm{E}-01$ & $<5.98 \mathrm{E}-01$ & $<7.36 \mathrm{E}-01$ & $<6.32 \mathrm{E}-01$ & $<6.05 \mathrm{E}-01$ & $<6.35 \mathrm{E}-01$ & $<7.03 \mathrm{E}-01$ & $<7.36 \mathrm{E}-01$ & $<6.24 \mathrm{E}-01$ & $<6.22 \mathrm{E}-01$ & $<5.51 \mathrm{E}-01$ & $<5.54 \mathrm{E}-01$ & $<5.12 \mathrm{E}-01$ & $<5.35 \mathrm{E}-01$ \\
\hline U & $5.21 \mathrm{E}+01$ & $5.16 \mathrm{E}+01$ & $<4.09 \mathrm{E}+01$ & $6.00 \mathrm{E}+01$ & $5.58 \mathrm{E}+01$ & $5.60 \mathrm{E}+01$ & $5.87 \mathrm{E}+01$ & $<4.09 \mathrm{E}+01$ & $3.86 \mathrm{E}+01$ & $5.43 \mathrm{E}+01$ & $4.59 \mathrm{E}+01$ & $4.69 \mathrm{E}+01$ & $4.14 \mathrm{E}+01$ & $5.31 \mathrm{E}+01$ \\
\hline V & $<6.37 \mathrm{E}-01$ & $<6.50 \mathrm{E}-01$ & $<8.00 \mathrm{E}-01$ & $<6.87 \mathrm{E}-01$ & $<6.58 \mathrm{E}-01$ & $<6.90 \mathrm{E}-01$ & $<7.64 \mathrm{E}-01$ & $<8.00 \mathrm{E}-01$ & $<6.77 \mathrm{E}-01$ & $<6.76 \mathrm{E}-01$ & $<5.98 \mathrm{E}-01$ & $<6.02 \mathrm{E}-01$ & $<5.56 \mathrm{E}-01$ & $<5.81 \mathrm{E}-01$ \\
\hline $\mathrm{Zn}$ & $6.30 \mathrm{E}+00$ & $6.62 \mathrm{E}+00$ & $<9.52 \mathrm{E}-01$ & $5.03 \mathrm{E}+00$ & $4.93 \mathrm{E}+00$ & $5.08 \mathrm{E}+00$ & $5.02 \mathrm{E}+00$ & $<9.52 \mathrm{E}-01$ & $5.09 \mathrm{E}+00$ & $5.22 \mathrm{E}+00$ & $5.38 \mathrm{E}+00$ & $5.59 \mathrm{E}+00$ & $5.58 \mathrm{E}+00$ & $5.68 \mathrm{E}+00$ \\
\hline $\mathrm{Zr}$ & $<4.95 \mathrm{E}-01$ & $<5.06 \mathrm{E}-01$ & $<6.22 \mathrm{E}-01$ & $<5.34 \mathrm{E}-01$ & $<5.11 \mathrm{E}-01$ & $<5.37 \mathrm{E}-01$ & $<5.94 \mathrm{E}-01$ & $<6.22 \mathrm{E}-01$ & $<5.27 \mathrm{E}-01$ & $<5.26 \mathrm{E}-01$ & $<4.65 \mathrm{E}-01$ & $<4.68 \mathrm{E}-01$ & $<4.32 \mathrm{E}-01$ & $<4.52 \mathrm{E}-01$ \\
\hline \multicolumn{15}{|c|}{ PuTTA - nominal counting uncertanty 7\% for Pu-238, 20\% for Pu239/240 } \\
\hline $\mathrm{Pu}-238$ & +04 & $2.23 \mathrm{E}+04$ & & $2.13 \mathrm{E}+04$ & & $.00 \mathrm{E}+04$ & $2.27 \mathrm{E}+04$ & & 9.31 & & & & +03 & $4.67 \mathrm{E}+03$ \\
\hline $1-239 / 240$ & $2.00 \mathrm{E}+03$ & $2.46 \mathrm{E}+03$ & & $2.06 \mathrm{E}+03$ & $2.04 \mathrm{E}+03$ & $2.11 \mathrm{E}+03$ & $2.16 \mathrm{E}+03$ & & $1.41 \mathrm{E}+03$ & $1.49 \mathrm{E}+03$ & $4.89 \mathrm{E}+02$ & $9.21 \mathrm{E}+02$ & $1.91 \mathrm{E}+03$ & 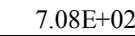 \\
\hline
\end{tabular}




\section{Table A-1. (contd.)}

\begin{tabular}{|c|c|c|c|c|c|c|c|c|c|c|c|c|c|c|c|c|}
\hline days) & 14 & 14 & andard 1 & 14 & 14 & 14 & 14 & Standard 2 & 14 & 14 & 21 & 21 & 21 & 21 & 21 & 21 \\
\hline & 0 & 0 & 0 & 5 & 5 & 10 & 10 & 10 & 0.2 & 0.2 & 0 & 0 & 5 & 5 & 10 & 10 \\
\hline $\mathrm{DF}(\mathrm{mL} / \mathrm{mL})$ & 10.44 & 10.89 & 12.70 & 9.77 & 9.80 & 9.31 & 10.10 & 12.70 & 11.77 & 10.41 & 11.26 & 10.68 & 9.35 & 10.07 & 11.21 & 11.60 \\
\hline LIMS numbers & 300303331 & 300303332 & 300303333 & 300303334 & 300303335 & 300303336 & 300303337 & 300303338 & 300303339 & 300303340 & 300303355 & 300303356 & 300303357 & 0303358 & 00303359 & 0030336 \\
\hline & 300303341 & 300303342 & & 00303343 & 300303344 & 300303345 & 300303346 & & 300303347 & & 300303361 & 300303362 & & & 300303365 & 300303366 \\
\hline \multicolumn{17}{|c|}{ ICP-ES $(\mathrm{mg} / \mathrm{L})-$ nominal uncertanty $=10 \%$} \\
\hline $\mathrm{Ag}$ & $<1.17 \mathrm{E}+00$ & $<1.22 \mathrm{E}+00$ & $<1.42 \mathrm{E}+00$ & $<1.09 \mathrm{E}+00$ & $<1.10 \mathrm{E}+00$ & $<1.04 \mathrm{E}+00$ & $<1.13 \mathrm{E}+00$ & $<1.42 \mathrm{E}+00$ & $<1.32 \mathrm{E}+00$ & $<1.17 \mathrm{E}+00$ & $<1.26 \mathrm{E}+00$ & $<1.20 \mathrm{E}+00$ & $<1.05 \mathrm{E}+00$ & $<1.13 \mathrm{E}+00$ & $<1.26 \mathrm{E}+00$ & $<1.30 \mathrm{E}+0$ \\
\hline $\mathrm{Al}$ & $9.09 \mathrm{E}+02$ & $9.13 \mathrm{E}+02$ & $1.06 \mathrm{E}+03$ & $9.02 \mathrm{E}+02$ & $9.09 \mathrm{E}+02$ & $9.00 \mathrm{E}+02$ & $9.07 \mathrm{E}+02$ & $1.07 \mathrm{E}+03$ & $9.21 \mathrm{E}+02$ & $9.23 \mathrm{E}+02$ & $9.21 \mathrm{E}+02$ & $9.30 \mathrm{E}+02$ & $9.21 \mathrm{E}+02$ & $9.23 \mathrm{E}+02$ & $9.22 \mathrm{E}+02$ & $9.07 \mathrm{E}+02$ \\
\hline B & $1.23 \mathrm{E}+02$ & $1.24 \mathrm{E}+02$ & $<2.53 \mathrm{E}+00$ & $1.22 \mathrm{E}+02$ & $1.23 \mathrm{E}+02$ & $1.21 \mathrm{E}+02$ & $1.22 \mathrm{E}+02$ & $<2.53 \mathrm{E}+00$ & $1.26 \mathrm{E}+02$ & $1.25 \mathrm{E}+02$ & $1.22 \mathrm{E}+02$ & $1.24 \mathrm{E}+02$ & $1.22 \mathrm{E}+02$ & $1.23 \mathrm{E}+02$ & $1.23 \mathrm{E}+02$ & $1.23 \mathrm{E}+02$ \\
\hline $\mathrm{Ba}$ & $<5.53 \mathrm{E}-01$ & $<5.77 \mathrm{E}-01$ & $<6.73 \mathrm{E}-01$ & $<5.18 \mathrm{E}-01$ & $<5.20 \mathrm{E}-01$ & $<4.94 \mathrm{E}-01$ & $<5.36 \mathrm{E}-01$ & -01 & $<6.24 \mathrm{E}-01$ & $<5.52 \mathrm{E}-01$ & $<5.97 \mathrm{E}-01$ & $<5.66 \mathrm{E}-01$ & $<4.96 \mathrm{E}-01$ & $<5.3$ & $<5.9$ & $15 \mathrm{E}-01$ \\
\hline $\mathrm{Be}$ & $<1.25 \mathrm{E}-01$ & $<1.31 \mathrm{E}-01$ & $<1.52 \mathrm{E}-01$ & $<1.17 \mathrm{E}-01$ & $<1.18 \mathrm{E}-01$ & $<1.12 \mathrm{E}-01$ & $<1.21 \mathrm{E}-01$ & $<1.5$ & $<1.41 \mathrm{E}-01$ & $<1.25 \mathrm{E}-01$ & $<1.35 \mathrm{E}-01$ & $<1.28 \mathrm{E}-01$ & $<1.12 \mathrm{E}-01$ & $<1.21 \mathrm{E}-01$ & $<1.34 \mathrm{E}-01$ & $<1.39 \mathrm{E}-01$ \\
\hline $\mathrm{Ca}$ & $1.70 \mathrm{E}+00$ & $1.37 \mathrm{E}+00$ & $9 \mathrm{E}+00$ & $1.50 \mathrm{E}+00$ & $1.42 \mathrm{E}+00$ & $1.80 \mathrm{E}+00$ & +00 & +00 & $1.89 \mathrm{E}+00$ & $1.92 \mathrm{E}+00$ & $1.86 \mathrm{E}+00$ & $1.78 \mathrm{E}+00$ & $1.97 \mathrm{E}+00$ & $1.95 \mathrm{E}+00$ & $2.49 \mathrm{E}+00$ & $2.54 \mathrm{E}+00$ \\
\hline $\mathrm{Cd}$ & $<8.45 \mathrm{E}-01$ & $<8.82 \mathrm{E}-01$ & $<1.03 \mathrm{E}+00$ & $<7.91 \mathrm{E}-01$ & $<7.94 \mathrm{E}-01$ & $<7.54 \mathrm{E}-01$ & $<8.18 \mathrm{E}-01$ & $<1.03 \mathrm{E}+00$ & $<9.53 \mathrm{E}-01$ & $<8.44 \mathrm{E}-01$ & $<1.61 \mathrm{E}+00$ & $<1.53 \mathrm{E}+00$ & $<1.34 \mathrm{E}+00$ & $<1.44 \mathrm{E}+00$ & $<1.60 \mathrm{E}+00$ & \\
\hline $\mathrm{Ce}$ & $<8.55 \mathrm{E}+00$ & $<8.92 \mathrm{E}+00$ & $<1.04 \mathrm{E}+01$ & $<8.00 \mathrm{E}+00$ & $<8.03 \mathrm{E}+00$ & $<7.63 \mathrm{E}+00$ & $<8.28 \mathrm{E}+00$ & & $<9.64 \mathrm{E}+00$ & $<8.53 \mathrm{E}+00$ & $<9.22 \mathrm{E}+00$ & $<8.75 \mathrm{E}+00$ & $<7.66 \mathrm{E}+00$ & $<8.25 \mathrm{E}+00$ & $<9.18 \mathrm{E}+00$ & $<9.50 \mathrm{E}+0$ \\
\hline Co & $<1.93 \mathrm{E}+00$ & $<2.01 \mathrm{E}+00$ & & $<1.811$ & $<1.8$ & 617 & & & $<2$. & & $<2$ & & & $<1.8$ & & \\
\hline $\mathrm{Cr}$ & $4.54 \mathrm{E}+01$ & $4.57 \mathrm{E}+01$ & $<$ & 4.58 & 4.6 & 4.6 & & & & & & & & & & +01 \\
\hline $\mathrm{Cu}$ & & $+\mathrm{E}+00$ & & & & & & & & & $<3$ & & & & & \\
\hline $\mathrm{Fe}$ & 00 & $E+00$ & & & & & & & & & & & & & & \\
\hline $\mathrm{Gd}$ & $<2.47 \mathrm{E}+00$ & $<2.58 \mathrm{E}+00$ & +00 & $<2.32 \mathrm{E}+00$ & $<2.32 \mathrm{E}+00$ & $<2.21 \mathrm{E}+00$ & $<2.3$ & & $<2.79$ & $<2.47 \mathrm{E}+00$ & $<2.6$ & $<2$ & $<2$. & $<2$. & $<2$ & $5 \mathrm{E}+00$ \\
\hline $\mathrm{K}$ & & $2.62 \mathrm{E}+02$ & & & & & & & & & & & & & & $\mathrm{E}+0$ \\
\hline $\mathrm{La}$ & $<1.31 \mathrm{E}+00$ & $<1$ & $<1$ & $<1.2$ & $<1.2$ & $<1.1$ & $<1$ & & $<1.48$ & $<1$ & $<1$ & & & $<1.2$ & $<1$. & \\
\hline $\mathrm{Li}$ & & & & & & & & & & & & & & & & +01 \\
\hline $\mathrm{Mg}$ & $1.46 \mathrm{E}-01$ & $<1.09 \mathrm{E}-01$ & $8-01$ & $<9.771$ & 9.80 & 02 & & & E-01 & E-01 & -01 & $\mathrm{E}-01$ & -02 & $<1.0$ & E-01 & $1.16 \mathrm{E}-01$ \\
\hline $\mathrm{Mn}$ & $<8.04 \mathrm{E}-01$ & $<8.38 \mathrm{E}-01$ & $\mathrm{E}-01$ & $<7.52 \mathrm{E}$ & $<7.55$ & $<7.1$ & & & $<9.06 \mathrm{E}-01$ & $<8$. $<$ & & & & & & \\
\hline Mo & $<1.03 \mathrm{E}+01$ & $<1.07 \mathrm{E}+01$ & $<1.25 \mathrm{E}+01$ & $<9.60 \mathrm{E}+00$ & $<9.64$ & $<9.1$ & $<9$ & $<1$. & $<1.1 \mathrm{t}$ & $<1$. & $<1$. & $<1$ & & $<9$ & $<1$. & $<1$ \\
\hline $\mathrm{Na}$ & $E+05$ & $1.34 \mathrm{E}+05$ & & $1.36 \mathrm{E}$ & 1.3 & -05 & & & +05 & $36 \mathrm{E}+05$ & & & & +05 & +05 & $1.39 \mathrm{E}+05$ \\
\hline $\mathrm{Ni}$ & $<2.16 \mathrm{E}+00$ & $<2.25 \mathrm{E}+00$ & & $<2.02 \mathrm{E}+00$ & $<2$. & & & & & & & & & & & \\
\hline$P$ & $1.27 \mathrm{E}+02$ & $\mathrm{E}+02$ & +02 & & & & & & +02 & & & & & -02 & & $\mathrm{DE}+02$ \\
\hline $\mathrm{Pb}$ & $<8.54 \mathrm{E}+00$ & $<8.91 \mathrm{E}+00$ & $4 E+01$ & $<7.99 \mathrm{E}+00$ & $<8.02$ & $<7.6$ & $<8$ & & $<9.63 \mathrm{E}+00$ & $<8.5$ & $<9$. & $<8$ & $<7$ & $<8.2$ & $<9.1$ & $9.49 \mathrm{E}+00$ \\
\hline $\mathrm{s}$ & & & & & & & & & & & & & & & & \\
\hline $\mathrm{Sb}$ & $<3.60 \mathrm{E}+01$ & $<3.76 \mathrm{E}+01$ & $E+01$ & $<3.37 \mathrm{E}$ & $<3.3$ & $<3.2$ & $<3$ & 01 & $<4$ & $<3$ & $<3$ & $<3$. & $<3$ & $<3$ & $<3.8$ & $<4.00 \mathrm{E}+01$ \\
\hline $\mathrm{Si}$ & & & & & & & & & & & & & & & & \\
\hline $\mathrm{Sn}$ & $<1.5$ & $<1$. & & $<1$. & $<1$. & & & & & & & & & & $<1$. & $<1$. \\
\hline $\mathrm{Sr}$ & $<5.22 \mathrm{E}-02$ & $<5.44 \mathrm{E}-02$ & $<6.35 \mathrm{E}-02$ & $<4.88 \mathrm{E}-02$ & $<4.90 \mathrm{E}-02$ & $<4.66 \mathrm{E}-02$ & $<5.05 \mathrm{E}-02$ & $<6.35 \mathrm{E}-02$ & $<5.88 \mathrm{E}-02$ & $<5.21 \mathrm{E}-02$ & $<5.63 \mathrm{E}-02$ & $<5.34 \mathrm{E}-02$ & $<4.68 \mathrm{E}-02$ & $<5.03 \mathrm{E}-02$ & $<5.60 \mathrm{E}-02$ & $<5.80 \mathrm{E}-02$ \\
\hline Th & $<5.34 \mathrm{E}+00$ & $<5.57 \mathrm{E}+00$ & & & & & & & & & & & & & & \\
\hline $\mathrm{Ti}$ & $<6.05 \mathrm{E}-01$ & $<6.31 \mathrm{E}-01$ & $<7.36 \mathrm{E}-01$ & $<5.67 \mathrm{E}-01$ & $<5.69 \mathrm{E}-01$ & $<5.40 \mathrm{E}-01$ & $<5.86 \mathrm{E}-01$ & & $<6.83 \mathrm{E}-01$ & $<6.04 \mathrm{E}-01$ & -01 & $<6$ & $<5$ & $<5$ & $<6.50 \mathrm{E}-01$ & $<6.73 \mathrm{E}-01$ \\
\hline $\mathrm{U}$ & $<6.32 \mathrm{E}+01$ & $<6.60 \mathrm{E}+01$ & $<7.69 \mathrm{E}+01$ & $<5.92 \mathrm{E}+01$ & $<5.94 \mathrm{E}+01$ & $<5.6$ & $<6.1$ & +01 & $<7.13 \mathrm{E}+01$ & $<6.31 \mathrm{E}+01$ & $<6$ & $<6$. & $<5$ & $<6.10 \mathrm{E}+01$ & $<6.79 \mathrm{E}+01$ & $<7.03 \mathrm{E}+01$ \\
\hline $\mathrm{V}$ & $<6.57 \mathrm{E}-01$ & & & & $<6.1$ & & & & & & & & & & & \\
\hline $\mathrm{Zn}$ & 5 & 0 & $<9$. $<$. & 00 & $4 \mathrm{E}+00$ & $9 \mathrm{E}+00$ & $\mathrm{E}+00$ & $<9.52 \mathrm{E}-01$ & $E+00$ & $5.92 \mathrm{E}+00$ & & & 5.4 & $5.24 \mathrm{E}+00$ & $5.43 \mathrm{E}+00$ & $5.26 \mathrm{E}+00$ \\
\hline $\mathrm{Zr}$ & $<5.11 \mathrm{E}-01$ & $<5.33 \mathrm{E}-01$ & $<6.22 \mathrm{E}-01$ & $<4.79 \mathrm{E}-01$ & $<4.80 \mathrm{E}-01$ & $<4.56 \mathrm{E}-01$ & $<4.95 \mathrm{E}-01$ & $<6.22 \mathrm{E}-01$ & $<5.77 \mathrm{E}-01$ & $<5.10 \mathrm{E}-01$ & $<5.52 \mathrm{E}-01$ & & & & & \\
\hline \multicolumn{17}{|c|}{ PuTTA - nominal counting uncertanty 7\% for Pu-238, 20\% for Pu } \\
\hline & & & & & & & & & & $7.15 \mathrm{E}+03$ & & & & & & \\
\hline $239 / 240$ & $1.24 \mathrm{E}+03$ & $9 \mathrm{E}+03$ & & $2.01 \mathrm{E}+02$ & $2.32 \mathrm{E}+02$ & $1.87 \mathrm{E}+02$ & $2.35 \mathrm{E}+02$ & & $9.43 \mathrm{E}+02$ & $9.93 \mathrm{E}+02$ & $8.67 \mathrm{E}+02$ & $1.11 \mathrm{E}+03$ & $1.65 \mathrm{E}+02$ & $1.70 \mathrm{E}+02$ & $1.43 \mathrm{E}+02$ & $1.65 \mathrm{E}+0$ \\
\hline
\end{tabular}


Table A-1. Analysis results of acid dilutions of sludge contact tests (contd.)

\begin{tabular}{|c|c|c|c|c|c|c|c|c|c|c|c|c|c|c|c|c|c|c|}
\hline hold time (days) & 35 & 35 & Standard 1 & 35 & 35 & 35 & 35 & Standard 2 & 35 & 35 & 35 & 35 & 35 & 35 & 35 & 35 & 56 & 56 \\
\hline glycolate $(\mathrm{g} / \mathrm{L})$ & 0 & 0 & 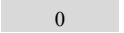 & 5 & 5 & 10 & 10 & 10 & 0.2 & 0.2 & 0 & 0 & 5 & 5 & (10 & 10 & 0 & ( \\
\hline $\mathrm{DF}(\mathrm{mL} / \mathrm{mL})$ & 10.74 & 9.26 & 12.70 & 11.78 & 10.95 & 12.04 & 10.23 & 12.70 & 9.45 & 12.27 & 10.65 & 10.91 & 11.65 & 10.58 & 10.65 & 12.28 & 8.99 & 10.87 \\
\hline \multirow[t]{2}{*}{ LIMS numbers } & 300303385 & 300303386 & 300303387 & 300303388 & 300303389 & 300303390 & 300303391 & 300303392 & 300303393 & 300303394 & 300303395 & 300303396 & 300303397 & 300303398 & 300303399 & 300303400 & & \\
\hline & \begin{tabular}{|l|}
300303401 \\
300308381
\end{tabular} & $\begin{array}{l}300303402 \\
300308382\end{array}$ & & 300303403 & 300303404 & 300303405 & 300303406 & & 300303407 & 300303408 & $\begin{array}{l}300303409 \\
300308383\end{array}$ & $\begin{array}{l}300303410 \\
300308384\end{array}$ & 300303411 & 300303412 & 300303413 & 300303414 & 300303380 & 300303381 \\
\hline \multicolumn{19}{|c|}{ ICP-ES $(\mathrm{mg} / \mathrm{L})$ - nominal uncertanty $=10 \%$} \\
\hline $\mathrm{Ag}$ & $\mid<1.20 \mathrm{E}+00$ & $<1.04 \mathrm{E}+00$ & $<1.42 \mathrm{E}+00$ & $<1.32 \mathrm{E}+00$ & $<1.23 \mathrm{E}+00$ & $<1.35 \mathrm{E}+00$ & $<1.15 \mathrm{E}+00$ & $<1.42 \mathrm{E}+00$ & $<1.06 \mathrm{E}+00$ & $<1.37 \mathrm{E}+00$ & $\mid<1.19 \mathrm{E}+00$ & $<1.22 \mathrm{E}+00$ & $<1.31 \mathrm{E}+00$ & $<1.19 \mathrm{E}+00$ & $<1.19 \mathrm{E}+00$ & $<1.37 \mathrm{E}+00$ & & \\
\hline $\mathrm{Al}$ & $9.53 \mathrm{E}+02$ & $\quad 9.54 \mathrm{E}+02$ & $1.04 \mathrm{E}+03$ & $9.45 \mathrm{E}+02$ & $9.47 \mathrm{E}+02$ & $9.25 \mathrm{E}+02$ & $9.27 \mathrm{E}+02$ & $1.04 \mathrm{E}+03$ & $9.64 \mathrm{E}+02$ & $9.58 \mathrm{E}+02$ & $9.63 \mathrm{E}+02$ & $9.58 \mathrm{E}+02$ & $9.44 \mathrm{E}+02$ & $9.38 \mathrm{E}+02$ & $9.40 \mathrm{E}+02$ & $\begin{array}{r}9.33 \mathrm{E}+02 \\
\end{array}$ & & \\
\hline B & $1.19 \mathrm{E}+02$ & $1.19 \mathrm{E}+02$ & $<2.53 \mathrm{E}+00$ & $1.16 \mathrm{E}+02$ & $1.17 \mathrm{E}+02$ & $1.17 \mathrm{E}+02$ & $1.16 \mathrm{E}+02$ & $<2.53 \mathrm{E}+00$ & $1.17 \mathrm{E}+02$ & $1.19 \mathrm{E}+02$ & $1.21 \mathrm{E}+02$ & $1.21 \mathrm{E}+02$ & $1.21 \mathrm{E}+02$ & $1.20 \mathrm{E}+02$ & $1.19 \mathrm{E}+02$ & $1.20 \mathrm{E}+02$ & & \\
\hline $\mathrm{Ba}$ & $<5.69 \mathrm{E}-01$ & $<4.91 \mathrm{E}-01$ & $<6.73 \mathrm{E}-01$ & $<6.24 \mathrm{E}-01$ & $<5.80 \mathrm{E}-01$ & $<6.38 \mathrm{E}-01$ & $<5.42 \mathrm{E}-01$ & $<6.73 \mathrm{E}-01$ & $<5.01 \mathrm{E}-01$ & $<6.50 \mathrm{E}-01$ & $<5.64 \mathrm{E}-01$ & $<5.78 \mathrm{E}-01$ & $<6.18 \mathrm{E}-01$ & $<5.61 \mathrm{E}-01$ & $<5.64 \mathrm{E}-01$ & $<6.51 \mathrm{E}-01$ & & \\
\hline $\mathrm{Be}$ & $<1.29 \mathrm{E}-01$ & $<1.11 \mathrm{E}-01$ & $<1.52 \mathrm{E}-01$ & $<1.41 \mathrm{E}-01$ & $<1.31 \mathrm{E}-01$ & $<1.44 \mathrm{E}-01$ & $<1.23 \mathrm{E}-01$ & $<1.52 \mathrm{E}-01$ & $<1.13 \mathrm{E}-01$ & $<1.47 \mathrm{E}-01$ & $<1.28 \mathrm{E}-01$ & $<1.31 \mathrm{E}-01$ & $<1.40 \mathrm{E}-01$ & $<1.27 \mathrm{E}-01$ & $<1.28 \mathrm{E}-01$ & $<1.47 \mathrm{E}-01$ & & \\
\hline $\mathrm{Ca}$ & 1.80E+00 & 1.44E+00 & $3.59 \mathrm{E}+00$ & $1.99 \mathrm{E}+00$ & $1.92 \mathrm{E}+00$ & $2.22 \mathrm{E}+00$ & $1.99 \mathrm{E}+00$ & 4. $29 \mathrm{E}+00$ & $1.63 \mathrm{E}+00$ & $2.01 \mathrm{E}+00$ & $2.11 \mathrm{E}+00$ & $1.88 \mathrm{E}+00$ & $2.55 \mathrm{E}+00$ & $2.51 \mathrm{E}+00$ & $7.31 \mathrm{E}+00$ & $2.50 \mathrm{E}+00$ & & \\
\hline $\mathrm{Cd}$ & $<1.54 \mathrm{E}+00$ & $<1.32 \mathrm{E}+00$ & $<1.82 \mathrm{E}+00$ & $<1.68 \mathrm{E}+00$ & $<1.57 \mathrm{E}+00$ & $<1.72 \mathrm{E}+00$ & $<1.46 \mathrm{E}+00$ & $<1.82 \mathrm{E}+00$ & $<1.35 \mathrm{E}+00$ & $<1.75 \mathrm{E}+00$ & $<1.52 \mathrm{E}+00$ & $<1.56 \mathrm{E}+00$ & $<1.67 \mathrm{E}+00$ & $<1.51 \mathrm{E}+00$ & $<1.52 \mathrm{E}+00$ & $<1.76 \mathrm{E}+00$ & & \\
\hline $\mathrm{Ce}$ & $<8.80 \mathrm{E}+00$ & $<7.58 \mathrm{E}+00$ & $<1.04 \mathrm{E}+01$ & $<9.65 \mathrm{E}+00$ & $<8.97 \mathrm{E}+00$ & $<9.86 \mathrm{E}+00$ & $<8.38 \mathrm{E}+00$ & $<1.04 \mathrm{E}+01$ & $<7.74 \mathrm{E}+00$ & $<1.00 \mathrm{E}+01$ & $<8.72 \mathrm{E}+00$ & $<8.93 \mathrm{E}+00$ & $<9.54 \mathrm{E}+00$ & $<8.67 \mathrm{E}+00$ & $<8.72 \mathrm{E}+00$ & $<1.01 \mathrm{E}+01$ & & \\
\hline Co & $<1.99 \mathrm{E}+00$ & $<1.71 \mathrm{E}+00$ & $<2.35 \mathrm{E}+00$ & $<2.18 \mathrm{E}+00$ & $<2.03 \mathrm{E}+00$ & $<2.23 \mathrm{E}+00$ & $<1.89 \mathrm{E}+00$ & $<2.35 \mathrm{E}+00$ & $<1.75 \mathrm{E}+00$ & $<2.27 \mathrm{E}+00$ & $<1.97 \mathrm{E}+00$ & $<2.02 \mathrm{E}+00$ & $<2.16 \mathrm{E}+00$ & $<1.96 \mathrm{E}+00$ & $<1.97 \mathrm{E}+00$ & $<2.27 \mathrm{E}+00$ & & \\
\hline $\mathrm{Cr}$ & $4.48 \mathrm{E}+01$ & 4. $44 \mathrm{E}+01$ & $<2.83 \mathrm{E}+00$ & $4.45 \mathrm{E}+01$ & $4.48 \mathrm{E}+01$ & $4.50 \mathrm{E}+01$ & $4.48 \mathrm{E}+01$ & $<2.83 \mathrm{E}+00$ & $4.42 \mathrm{E}+01$ & 4.45E +01 & $4.62 \mathrm{E}+01$ & 4. $60 \mathrm{E}+01$ & $4.68 \mathrm{E}+01$ & $4.67 \mathrm{E}+01$ & 4. $66 \mathrm{E}+01$ & 4.70E +01 & & \\
\hline $\mathrm{Cu}$ & $<3.19 \mathrm{E}+00$ & $<2.75 \mathrm{E}+00$ & $<3.77 \mathrm{E}+00$ & $<3.50 \mathrm{E}+00$ & $<3.25 \mathrm{E}+00$ & $<3.58 \mathrm{E}+00$ & $<3.04 \mathrm{E}+00$ & $<3.77 \mathrm{E}+00$ & $<2.81 \mathrm{E}+00$ & $<3.64 \mathrm{E}+00$ & $<3.16 \mathrm{E}+00$ & $<3.24 \mathrm{E}+00$ & $5.01 \mathrm{E}+00$ & $<3.14 \mathrm{E}+00$ & $<3.16 \mathrm{E}+00$ & $<3.65 \mathrm{E}+00$ & & \\
\hline $\mathrm{Fe}$ & $2.59 \mathrm{E}+00$ & $1.58 \mathrm{E}+00$ & $<1.56 \mathrm{E}+00$ & $4.57 \mathrm{E}+00$ & $5.25 \mathrm{E}+00$ & $6.33 \mathrm{E}+00$ & $6.06 \mathrm{E}+00$ & $<1.56 \mathrm{E}+00$ & $2.94 \mathrm{E}+00$ & $1.72 \mathrm{E}+00$ & $1.94 \mathrm{E}+00$ & 2.12E+00 & 4.86E+00 & $5.07 \mathrm{E}+00$ & $7.25 \mathrm{E}+00$ & $6.15 \mathrm{E}+00$ & & \\
\hline $\mathrm{Gd}$ & $<2.55 \mathrm{E}+00$ & $<2.19 \mathrm{E}+00$ & $<3.01 \mathrm{E}+00$ & $<2.79 \mathrm{E}+00$ & $<2.60 \mathrm{E}+00$ & $<2.85 \mathrm{E}+00$ & $<2.42 \mathrm{E}+00$ & $<3.01 \mathrm{E}+00$ & $<2.24 \mathrm{E}+00$ & $<2.91 \mathrm{E}+00$ & $<2.52 \mathrm{E}+00$ & $<2.59 \mathrm{E}+00$ & $<2.76 \mathrm{E}+00$ & $<2.51 \mathrm{E}+00$ & $<2.52 \mathrm{E}+00$ & $<2.91 \mathrm{E}+00$ & & \\
\hline $\mathrm{K}$ & $2.59 \mathrm{E}+02$ & $2.75 \mathrm{E}+02$ & $3.34 \mathrm{E}+01$ & $2.74 \mathrm{E}+02$ & $2.74 \mathrm{E}+02$ & $2.64 \mathrm{E}+02$ & $2.73 \mathrm{E}+02$ & $<3.02 \mathrm{E}+01$ & $2.65 \mathrm{E}+02$ & $2.65 \mathrm{E}+02$ & $2.53 \mathrm{E}+02$ & $2.54 \mathrm{E}+02$ & $2.79 \mathrm{E}+02$ & $2.69 \mathrm{E}+02$ & $2.73 \mathrm{E}+02$ & $2.63 \mathrm{E}+02$ & & \\
\hline $\mathrm{La}$ & $<1.35 \mathrm{E}+00$ & $<1.17 \mathrm{E}+00$ & $<1.60 \mathrm{E}+00$ & $<1.48 \mathrm{E}+00$ & $<1.38 \mathrm{E}+00$ & $<1.52 \mathrm{E}+00$ & $<1.29 \mathrm{E}+00$ & $<1.60 \mathrm{E}+00$ & $<1.19 \mathrm{E}+00$ & $<1.55 \mathrm{E}+00$ & $<1.34 \mathrm{E}+00$ & $<1.37 \mathrm{E}+00$ & $<1.47 \mathrm{E}+00$ & $<1.33 \mathrm{E}+00$ & $<1.34 \mathrm{E}+00$ & $<1.55 \mathrm{E}+00$ & & \\
\hline $\mathrm{Li}$ & $5.20 \mathrm{E}+01$ & $5.20 \mathrm{E}+01$ & $<8.76 \mathrm{E}-01$ & $5.17 \mathrm{E}+01$ & $5.20 \mathrm{E}+01$ & $5.15 \mathrm{E}+01$ & $5.11 \mathrm{E}+01$ & $<8.76 \mathrm{E}-01$ & $5.27 \mathrm{E}+01$ & $5.23 \mathrm{E}+01$ & $5.21 \mathrm{E}+01$ & $5.16 \mathrm{E}+01$ & $5.17 \mathrm{E}+01$ & $5.13 \mathrm{E}+01$ & $5.11 \mathrm{E}+01$ & & & \\
\hline $\mathrm{Mg}$ & $<1.07 \mathrm{E}-01$ & $<9.26 \mathrm{E}-02$ & 6.16E-01 & $<1.18 \mathrm{E}-01$ & $<1.10 \mathrm{E}-01$ & $<1.20 \mathrm{E}-01$ & $<1.02 \mathrm{E}-01$ & $1.10 \mathrm{E}+00$ & $<9.45 \mathrm{E}-02$ & $<1.23 \mathrm{E}-01$ & $<1.06 \mathrm{E}-01$ & $<1.09 \mathrm{E}-01$ & $<1.17 \mathrm{E}-01$ & $<1.06 \mathrm{E}-01$ & $<1.18 \mathrm{E}+00$ & $<1.23 \mathrm{E}-01$ & & \\
\hline $\mathrm{Mn}$ & $<8.27 \mathrm{E}-01$ & $<7.13 \mathrm{E}-01$ & $<9.78 \mathrm{E}-01$ & $<9.07 \mathrm{E}-01$ & $<8.43 \mathrm{E}-01$ & $<9.27 \mathrm{E}-01$ & $<7.88 \mathrm{E}-01$ & $<9.78 \mathrm{E}-01$ & $<7.28 \mathrm{E}-01$ & $<9.45 \mathrm{E}-01$ & $<8.20 \mathrm{E}-01$ & $<8.40 \mathrm{E}-01$ & $<8.97 \mathrm{E}-01$ & $<8.15 \mathrm{E}-01$ & $<8.20 \mathrm{E}-01$ & $<9.45 \mathrm{E}-01$ & & \\
\hline Mo & $<1.06 \mathrm{E}+01$ & $<9.10 \mathrm{E}+00$ & $<1.25 \mathrm{E}+01$ & $<1.16 \mathrm{E}+01$ & $<1.08 \mathrm{E}+01$ & $<1.18 \mathrm{E}+01$ & $<1.01 \mathrm{E}+01$ & $<1.25 \mathrm{E}+01$ & $<9.29 \mathrm{E}+00$ & $<1.21 \mathrm{E}+01$ & $<1.05 \mathrm{E}+01$ & $<1.07 \mathrm{E}+01$ & $<1.15 \mathrm{E}+01$ & $<1.04 \mathrm{E}+01$ & $<1.05 \mathrm{E}+01$ & $<1.21 \mathrm{E}+01$ & & \\
\hline $\mathrm{Na}$ & $1.34 \mathrm{E}+05$ & $1.34 \mathrm{E}+05$ & 1.49E+05 & $1.35 \mathrm{E}+05$ & $1.36 \mathrm{E}+05$ & $1.37 \mathrm{E}+05$ & 1.37E+05 & $1.51 \mathrm{E}+05$ & $1.36 \mathrm{E}+05$ & $1.36 \mathrm{E}+05$ & $1.34 \mathrm{E}+05$ & $1.33 \mathrm{E}+05$ & $1.34 \mathrm{E}+05$ & $1.33 \mathrm{E}+05$ & $1.35 \mathrm{E}+05$ & $\begin{array}{l}1.35 \mathrm{E}+05 \\
1.05\end{array}$ & & \\
\hline $\mathrm{Ni}$ & $<2.22 \mathrm{E}+00$ & $<1.92 \mathrm{E}+00$ & $<2.63 \mathrm{E}+00$ & $<2.44 \mathrm{E}+00$ & $<2.27 \mathrm{E}+00$ & $<2.49 \mathrm{E}+00$ & $<2.12 \mathrm{E}+00$ & $<2.63 \mathrm{E}+00$ & $<1.96 \mathrm{E}+00$ & $<2.54 \mathrm{E}+00$ & $<2.20 \mathrm{E}+00$ & $<2.26 \mathrm{E}+00$ & $<2.41 \mathrm{E}+00$ & $<2.19 \mathrm{E}+00$ & $<2.20 \mathrm{E}+00$ & $<2.54 \mathrm{E}+00$ & & \\
\hline $\mathrm{P}$ & $1.13 \mathrm{E}+02$ & $1.08 \mathrm{E}+02$ & $1.31 \mathrm{E}+02$ & $1.12 \mathrm{E}+02$ & $1.14 \mathrm{E}+02$ & $1.08 \mathrm{E}+02$ & $1.11 \mathrm{E}+02$ & $1.28 \mathrm{E}+02$ & $1.12 \mathrm{E}+02$ & $1.12 \mathrm{E}+02$ & $1.20 \mathrm{E}+02$ & $1.24 \mathrm{E}+02$ & $1.22 \mathrm{E}+02$ & $1.17 \mathrm{E}+02$ & 1 & 1.1 & & \\
\hline $\mathrm{Pb}$ & $<8.78 \mathrm{E}+00$ & $<7.58 \mathrm{E}+00$ & $<1.04 \mathrm{E}+01$ & $<9.63 \mathrm{E}+00$ & $<8.96 \mathrm{E}+00$ & $<9.85 \mathrm{E}+00$ & $<8.37 \mathrm{E}+00$ & $<1.04 \mathrm{E}+01$ & $<7.73 \mathrm{E}+00$ & $<1.00 \mathrm{E}+01$ & $<8.71 E+00$ & $<8.92 \mathrm{E}+00$ & $<9.53 \mathrm{E}+00$ & $<8.66 \mathrm{E}+00$ & $<8.71 \mathrm{E}+00$ & $<1.00 \mathrm{E}+01$ & & \\
\hline $\mathrm{s}$ & $1.25 \mathrm{E}+03$ & $1.11 \mathrm{E}+03$ & $9.50 \mathrm{E}+02$ & $1.34 \mathrm{E}+03$ & $1.22 \mathrm{E}+03$ & $1.26 \mathrm{E}+03$ & $1.13 \mathrm{E}+03$ & $8.98 \mathrm{E}+02$ & $1.35 \mathrm{E}+03$ & $1.02 \mathrm{E}+03$ & $1.11 \mathrm{E}+03$ & $1.20 \mathrm{E}+03$ & $1.01 \mathrm{E}+03$ & $8.32 \mathrm{E}+02$ & $9.15 \mathrm{E}+02$ & $\begin{array}{r}9.49 \mathrm{E}+02 \\
\end{array}$ & & \\
\hline $\mathrm{Sb}$ & $<3.71 \mathrm{E}+01$ & $<3.20 \mathrm{E}+01$ & $<4.38 \mathrm{E}+01$ & $<4.06 \mathrm{E}+01$ & $<3.78 \mathrm{E}+01$ & $<4.15 \mathrm{E}+01$ & $<3.53 \mathrm{E}+01$ & $<4.3$ & $<3.26 \mathrm{E}+01$ & $<4.23 \mathrm{E}+01$ & $<3.67 \mathrm{E}+01$ & $<3.76 \mathrm{E}+01$ & $<4.0$ & $<3$. & $<3.67 \mathrm{E}+01$ & $<4.24 \mathrm{E}+01$ & & \\
\hline $\mathrm{Si}$ & $5.54 \mathrm{E}+01$ & $5.45 \mathrm{E}+01$ & $<5.05 \mathrm{E}+00$ & $5.18 \mathrm{E}+01$ & $5.30 \mathrm{E}+01$ & $5.13 \mathrm{E}+01$ & $5.23 \mathrm{E}+01$ & $<5$. & $5.43 \mathrm{E}+01$ & & $5.46 \mathrm{E}+01$ & & & +01 & $5.42 \mathrm{E}+01$ & $5.39 \mathrm{E}+01$ & & \\
\hline $\mathrm{Sn}$ & $<1.27 \mathrm{E}+01$ & $<1.09 \mathrm{E}+01$ & $<1.50 \mathrm{E}+01$ & $<1.39 \mathrm{E}+01$ & $<1.29 \mathrm{E}+01$ & $<1.42 \mathrm{E}+01$ & $<1.21 \mathrm{E}+01$ & $<1.50 \mathrm{E}+01$ & $<1.12 \mathrm{E}+01$ & $<1.45 \mathrm{E}+01$ & $<1.26 \mathrm{E}+01$ & $<1.29 \mathrm{E}+01$ & $<1.38 \mathrm{E}+01$ & $<1.25 \mathrm{E}+01$ & $<1.26 \mathrm{E}+01$ & $<1.45 \mathrm{E}+01$ & & \\
\hline $\mathrm{Sr}$ & $<5.37 \mathrm{E}-02$ & $<4.63 \mathrm{E}-02$ & $<6.35 \mathrm{E}-02$ & $<5.89 \mathrm{E}-02$ & $<5.48 \mathrm{E}-02$ & $<6.02 \mathrm{E}-02$ & $<5.11 \mathrm{E}-02$ & $<6.35 \mathrm{E}-02$ & $<4.73 \mathrm{E}-02$ & $<6.13 \mathrm{E}-02$ & $<5.32 \mathrm{E}-02$ & $<5.45 \mathrm{E}-02$ & $<5.83 \mathrm{E}-02$ & $<5.29 \mathrm{E}-02$ & $<5.32 \mathrm{E}-02$ & $<6.14 \mathrm{E}-02$ & & \\
\hline $\mathrm{Th}$ & $<5.50 \mathrm{E}+00$ & $<4.74 \mathrm{E}+00$ & $<6.50 \mathrm{E}+00$ & $<6.03 \mathrm{E}+00$ & $<5.61 \mathrm{E}+00$ & $<6.17 \mathrm{E}+00$ & $<5.24 \mathrm{E}+00$ & $<6.50 \mathrm{E}+00$ & $<4.84 \mathrm{E}+00$ & $<6.28 \mathrm{E}+00$ & $<5.45 \mathrm{E}+00$ & $<5.58 \mathrm{E}+00$ & $<5.97 \mathrm{E}+00$ & $<5.42 \mathrm{E}+00$ & $<5.45 \mathrm{E}+00$ & $<6.29 \mathrm{E}+00$ & & \\
\hline $\mathrm{Ti}$ & $<6.23 \mathrm{E}-01$ & $<5.37 \mathrm{E}-01$ & $<7.36 \mathrm{E}-01$ & $<6.83 \mathrm{E}-01$ & $<6.35 \mathrm{E}-01$ & $<6.98 \mathrm{E}-01$ & $<5.93 \mathrm{E}-01$ & $<7.36 \mathrm{E}-01$ & $<5.48 \mathrm{E}-01$ & $<7.12 \mathrm{E}-01$ & $<6.18 \mathrm{E}-01$ & $<6.33 \mathrm{E}-01$ & $<6.76 \mathrm{E}-01$ & $<6.14 \mathrm{E}-01$ & $<6.17 \mathrm{E}-01$ & $<7.12 \mathrm{E}-01$ & & \\
\hline $\mathrm{U}$ & $<3.46 \mathrm{E}+01$ & $<2.98 \mathrm{E}+01$ & $<4.09 \mathrm{E}+01$ & $<3.79 \mathrm{E}+01$ & $<3.53 \mathrm{E}+01$ & $<3.88 \mathrm{E}+01$ & $<3.29 \mathrm{E}+01$ & $<4.09 \mathrm{E}+01$ & $<3.04 \mathrm{E}+01$ & $<3.95 \mathrm{E}+01$ & $<3.43 \mathrm{E}+01$ & $<3.51 \mathrm{E}+01$ & $<3.75 \mathrm{E}+01$ & $<3.41 \mathrm{E}+01$ & $<3.43 \mathrm{E}+01$ & $<3.95 \mathrm{E}+01$ & & \\
\hline $\mathrm{v}$ & $<6.77 \mathrm{E}-01$ & $<5.83 \mathrm{E}-01$ & $<8.00 \mathrm{E}-01$ & $<7.42 \mathrm{E}-01$ & $<6.90 \mathrm{E}-01$ & $<7.59 \mathrm{E}-01$ & $<6.44 \mathrm{E}-01$ & $<8.00 \mathrm{E}-01$ & $<5.96 \mathrm{E}-01$ & $<7.73 \mathrm{E}-01$ & $<6.71 \mathrm{E}-01$ & $<6.87 \mathrm{E}-01$ & $<7.34 \mathrm{E}-01$ & $<6.67 \mathrm{E}-01$ & $<6.71 \mathrm{E}-01$ & $<7.73 \mathrm{E}-01$ & & \\
\hline $\mathrm{Zn}$ & $4.80 \mathrm{E}+00$ & $\quad 4.72 \mathrm{E}+00$ & $<9.52 \mathrm{E}-01$ & $4.71 \mathrm{E}+00$ & $4.57 \mathrm{E}+00$ & $4.93 \mathrm{E}+00$ & & $<9.52 \mathrm{E}-01$ & $4.74 \mathrm{E}+00$ & $4.69 \mathrm{E}+00$ & $5.13 \mathrm{E}+00$ & 5 & 7.1 & 5.00 & 6.1 & 5.0 & & \\
\hline $\mathrm{Zr}$ & $<5.26 \mathrm{E}-01$ & $<4.54 \mathrm{E}-01$ & $<6.22 \mathrm{E}-01$ & $<5.77 \mathrm{E}-01$ & $<5.37 \mathrm{E}-01$ & $<5.90 \mathrm{E}-01$ & $<5.01 \mathrm{E}-01$ & $<6.22 \mathrm{E}-01$ & $<4.63 \mathrm{E}-01$ & $<6.01 \mathrm{E}-01$ & $<5.22 \mathrm{E}-01$ & $<5.34 \mathrm{E}-01$ & $<5.71 \mathrm{E}-01$ & $<5.19 \mathrm{E}-01$ & $<5.22 \mathrm{E}-01$ & $<6.02 \mathrm{E}-01$ & & \\
\hline \multicolumn{19}{|c|}{ PuTTA - nominal counting umcertanty $\sim 7 \%$ for Pu-238, 20\% for Pu239/240 } \\
\hline 238 & 6. & & & & & $1.95 \mathrm{E}+03$ & & & $6.63 \mathrm{E}+03$ & $5.43 \mathrm{E}+03$ & $6.38 \mathrm{E}+03$ & $6.82 \mathrm{E}+03$ & & & & & & \\
\hline$-239 / 240$ & $9.47 \mathrm{E}+02$ & 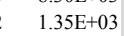 & & $1.96 \mathrm{E}+02$ & $2.81 \mathrm{E}+02$ & $7.89 \mathrm{E}+01$ & $1.16 \mathrm{E}+02$ & & $8.56 \mathrm{E}+02$ & $7.12 \mathrm{E}+02$ & $1.08 \mathrm{E}+03$ & $1.07 \mathrm{E}+03$ & 4.73E+01 & $7.19 \mathrm{E}+01$ & $3.49 \mathrm{E}+01$ & 4.44E+01 & $1.32 \mathrm{E}+03$ & $1.13 \mathrm{E}+$ \\
\hline & $7.06 \mathrm{E}+03$ & 1. & & & & & & & & & & $7.45 \mathrm{E}+03$ & & & & & & \\
\hline $\mathrm{Pu}-239 / 240$ & $9.43 \mathrm{E}+02$ & $1.64 \mathrm{E}+02$ & & & & & & & & & $9.11 \mathrm{E}+02$ & $8.06 \mathrm{E}+02$ & & & & & & \\
\hline
\end{tabular}


Table A-2. ICP-MS of acid dilutions of sludge contact tests $(\mathrm{mg} / \mathrm{L})$, nominal uncertainty $=\mathbf{2 0} \%$

\begin{tabular}{|c|c|c|c|c|c|c|c|c|c|c|c|c|c|c|}
\hline lays) & 0 & 0 & $\begin{array}{l}\text { Standard } 1 \\
\end{array}$ & 0 & 0 & 0 & 0 & Standard 2 & 1 & 1 & 7 & 7 & 7 & 7 \\
\hline glycolate $(\mathrm{g} / \mathrm{L})$ & 0 & 0 & 0 & 5 & 5 & 10 & 10 & 10 & 0 & 0 & 5 & 5 & 10 & 10 \\
\hline $\mathrm{DF}(\mathrm{mL} / \mathrm{mL})$ & 10.11 & 10.32 & 12.70 & 10.90 & 10.44 & 10.95 & 12.13 & 12.70 & 10.75 & 10.73 & 9.49 & 9.55 & 8.83 & 9.22 \\
\hline LIMS numbers & 300303312 & 300303313 & 300303314 & 300303315 & 300303316 & 300303317 & 300303318 & 300303319 & 300303297 & 300303298 & 300303299 & 300303300 & 300303301 & 300303302 \\
\hline mass $(\mathrm{m} / \mathrm{z})=59$ & $<1.77 \mathrm{E}-01$ & $<1.81 \mathrm{E}-01$ & $<2.22 \mathrm{E}-01$ & $<1.91 \mathrm{E}-01$ & $<1.83 \mathrm{E}-01$ & $<1.92 \mathrm{E}-01$ & $<2.12 \mathrm{E}-01$ & $<2.22 \mathrm{E}-01$ & $\begin{array}{c}<7.53 \mathrm{E}-02 \\
\end{array}$ & $<7.51 \mathrm{E}-02$ & $<6.65 \mathrm{E}-02$ & $<6.69 \mathrm{E}-02$ & $<6.18 \mathrm{E}-02$ & $<6.45 \mathrm{E}-02$ \\
\hline 82 & $<9.73 \mathrm{E}+00$ & $<9.93 \mathrm{E}+00$ & $<1.22 \mathrm{E}+01$ & $<1.05 \mathrm{E}+01$ & $<1.00 \mathrm{E}+01$ & $<1.05 \mathrm{E}+01$ & $<1.17 \mathrm{E}+01$ & $<1.22 \mathrm{E}+01$ & $<1.04 \mathrm{E}+00$ & $<1.04 \mathrm{E}+00$ & $<9.21 \mathrm{E}-01$ & $<9.27 \mathrm{E}-01$ & $<8.56 \mathrm{E}-01$ & $<8.94 \mathrm{E}-01$ \\
\hline 84 & $<7.83 \mathrm{E}-01$ & $<8.00 \mathrm{E}-01$ & $<9.84 \mathrm{E}-01$ & $<8.45 \mathrm{E}-01$ & $<8.09 \mathrm{E}-01$ & $<8.49 \mathrm{E}-01$ & $<9.40 \mathrm{E}-01$ & $<9.84 \mathrm{E}-01$ & $<6.56 \mathrm{E}-01$ & $<6.55 \mathrm{E}-01$ & & $<5.83 \mathrm{E}-01$ & $<5.38 \mathrm{E}-01$ & \\
\hline 85 & $5.68 \mathrm{E}-01$ & $7.31 \mathrm{E}-01$ & $<1.59 \mathrm{E}-01$ & $7.55 \mathrm{E}-01$ & $3.87 \mathrm{E}-01$ & 3.32E- 01 & $4.07 \mathrm{E}-01$ & $2.19 \mathrm{E}-01$ & $2.40 \mathrm{E}-01$ & $2.45 \mathrm{E}-01$ & 2.49E-01 & $1.84 \mathrm{E}-01$ & $2.66 \mathrm{E}-01$ & $2.74 \mathrm{E}-01$ \\
\hline 86 & $<2.27 \mathrm{E}-01$ & $<2.32 \mathrm{E}-01$ & $<2.86 \mathrm{E}-01$ & $<2.45 \mathrm{E}-01$ & $<2.35 \mathrm{E}-01$ & $<2.46 \mathrm{E}-01$ & $<2.73 \mathrm{E}-01$ & $<2.86 \mathrm{E}-01$ & $<9.68 \mathrm{E}-02$ & $<9.66 \mathrm{E}-02$ & $<8.54 \mathrm{E}-02$ & $<8.60 \mathrm{E}-02$ & $<7.94 \mathrm{E}-02$ & $<8.30 \mathrm{E}-02$ \\
\hline 87 & $6.60 \mathrm{E}-01$ & $6.27 \mathrm{E}-01$ & $<1.27 \mathrm{E}-01$ & $7.90 \mathrm{E}-01$ & 4.21E-01 & 4.94E- 01 & $6.10 \mathrm{E}-01$ & $1.73 \mathrm{E}-01$ & 3.53E-01 & 4.20E- 01 & $3.94 \mathrm{E}-01$ & $3.72 \mathrm{E}-01$ & $3.56 \mathrm{E}-01$ & $4.65 \mathrm{E}-01$ \\
\hline 88 & $2.30 \mathrm{E}-01$ & $<2.32 \mathrm{E}-01$ & $<2.86 \mathrm{E}-01$ & 2.65E-01 & $<2.35 \mathrm{E}-01$ & $<2.46 \mathrm{E}-01$ & $<2.73 \mathrm{E}-01$ & $<2.86 \mathrm{E}-01$ & $<3.23 \mathrm{E}-02$ & $<3.22 \mathrm{E}-02$ & $<2.85 \mathrm{E}-02$ & $<2.87 \mathrm{E}-02$ & $<2.65 \mathrm{E}-02$ & $<2.77 \mathrm{E}-02$ \\
\hline 89 & $<5.05 \mathrm{E}-02$ & $<5.16 \mathrm{E}-02$ & $<6.35 \mathrm{E}-02$ & $<5.45 \mathrm{E}-02$ & $<5.22 \mathrm{E}-02$ & $<5.48 \mathrm{E}-02$ & $<6.06 \mathrm{E}-02$ & $<6.35 \mathrm{E}-02$ & $<3.23 \mathrm{E}-02$ & $<3.22 \mathrm{E}-02$ & $<2.85 \mathrm{E}-02$ & $<2.87 \mathrm{E}-02$ & $<2.65 \mathrm{E}-02$ & $<2.77 \mathrm{E}-02$ \\
\hline 90 & $<1.01 \mathrm{E}-01$ & $<1.03 \mathrm{E}-01$ & $<1.27 \mathrm{E}-01$ & $<1.09 \mathrm{E}-01$ & $<1.04 \mathrm{E}-01$ & $<1.10 \mathrm{E}-01$ & $<1.21 \mathrm{E}-01$ & $<1.27 \mathrm{E}-01$ & $<2.15 \mathrm{E}-02$ & $<2.15 \mathrm{E}-02$ & $<1.90 \mathrm{E}-02$ & $<1.91 \mathrm{E}-02$ & $<1.7$ & $<1.84 \mathrm{E}-02$ \\
\hline 91 & $<5.05 \mathrm{E}-02$ & $<5.16 \mathrm{E}-02$ & $<6.35 \mathrm{E}-02$ & $<5.45 \mathrm{E}-02$ & $<5.22 \mathrm{E}-02$ & $<5.48 \mathrm{E}-02$ & $<6.06 \mathrm{E}-02$ & $<6.35 \mathrm{E}-02$ & $<2.15 \mathrm{E}-02$ & $<2.15 \mathrm{E}-02$ & $<1.90 \mathrm{E}-02$ & $<1.91 \mathrm{E}-02$ & $<1.77 \mathrm{E}-02$ & $<1.84 \mathrm{E}-02$ \\
\hline 92 & $9.23 \mathrm{E}-01$ & $9.04 \mathrm{E}-01$ & $7.00 \mathrm{E}-02$ & $9.44 \mathrm{E}-01$ & $5.46 \mathrm{E}-01$ & 4.10E- 01 & $5.93 \mathrm{E}-01$ & $5.54 \mathrm{E}-01$ & $3.62 \mathrm{E}-01$ & -01 & $3.09 \mathrm{E}-01$ & -01 & -01 & 3.05E-01 \\
\hline 93 & $<5.05 \mathrm{E}-02$ & $<5.16 \mathrm{E}-02$ & $\mathrm{E}-02$ & $<5.4$ & $<5.2$ & & E-02 & & $\mathrm{E}-02$ & & & & & $\mathrm{E}-02$ \\
\hline 94 & $4.19 \mathrm{E}-01$ & $6.00 \mathrm{E}-01$ & $<1.27 \mathrm{E}-01$ & 6.41E-01 & $2.49 \mathrm{E}-01$ & 2.49E-01 & $2.58 \mathrm{E}-01$ & $63 \mathrm{E}-01$ & $2.41 \mathrm{E}-01$ & $1.17 \mathrm{E}-01$ & $1.38 \mathrm{E}-01$ & 01 & -01 & $1.60 \mathrm{E}-01$ \\
\hline 95 & $1.78 \mathrm{E}+00$ & $1.91 \mathrm{E}+00$ & $<1.27 \mathrm{E}-01$ & $1.96 \mathrm{E}+00$ & +00 & 00 & +00 & E-01 & $1.16 \mathrm{E}+00$ & & -00 & & 1.1 & $1.18 \mathrm{E}+00$ \\
\hline 96 & $1.31 \mathrm{E}+00$ & $9.77 \mathrm{E}-01$ & $<6.35 \mathrm{E}-02$ & $1.13 \mathrm{E}+00$ & E-01 & -01 & E-01 & E-01 & 2.82 & E- 01 & & & & $4 \mathrm{E}-01$ \\
\hline 97 & $1.29 \mathrm{E}+00$ & $1.48 \mathrm{E}+00$ & $<6.35 \mathrm{E}-02$ & +00 & 1.17 & 1.03 & 01 & 01 & & & & & & $9.71 \mathrm{E}-01$ \\
\hline 98 & $2.30 \mathrm{E}+00$ & $2.19 \mathrm{E}+00$ & $8-02$ & 2.4 & 1.5 & 1.44 & +00 & & 1.24 & & 1.2 & & & $1.25 \mathrm{E}+00$ \\
\hline 99 & 3E-01 & $2 \mathrm{E}-01$ & $<6.3$ & 00 & 1.00 & 9. & $1.25 \mathrm{E}+00$ & $<6.35 \mathrm{E}-02$ & $8.23 \mathrm{E}-01$ & & 01 & -01 & & $9.54 \mathrm{E}-01$ \\
\hline 100 & $1.33 \mathrm{E}+00$ & $9 \mathrm{E}+00$ & $<6.35 \mathrm{E}-02$ & $1.75 \mathrm{E}+00$ & $1.23 \mathrm{E}+00$ & $1.17 \mathrm{E}+00$ & $1.26 \mathrm{E}+00$ & $2.45 \mathrm{E}-01$ & $1.04 \mathrm{E}+00$ & $1.07 \mathrm{E}+00$ & +00 & 1.05 & +00 & $9.84 \mathrm{E}-01$ \\
\hline 101 & $9.14 \mathrm{E}-01$ & $1.12 \mathrm{E}+00$ & $<9.52 \mathrm{E}-02$ & 8.95E-01 & $9.41 \mathrm{E}-01$ & 8.54E-01 & $8.85 \mathrm{E}-01$ & $<9.52 \mathrm{E}-02$ & $9.02 \mathrm{E}-01$ & $8.85 \mathrm{E}-01$ & -01 & 01 & & $.05 \mathrm{E}-01$ \\
\hline 102 & E-01 & 50E-01 & $<6.35 \mathrm{E}-02$ & 01 & 1 & 01 & -01 & $<6.35 \mathrm{E}-02$ & 01 & & & & & E-01 \\
\hline 103 & E-01 & & $<1.59 \mathrm{E}-01$ & & & & & & & & & & & 19E-01 \\
\hline 104 & $3.98 \mathrm{E}-01$ & 4.33E-01 & $<6.35 \mathrm{E}-02$ & $6.33 \mathrm{E}-01$ & 4.63E-01 & $3.87 \mathrm{E}-01$ & 4.31E-01 & $<6.35 \mathrm{E}-02$ & 4.77E-01 & 4.73E-01 & 4.45E-01 & $.40 \mathrm{E}-01$ & $34 \mathrm{E}-01$ & $4.54 \mathrm{E}-01$ \\
\hline 105 & $<5.05 \mathrm{E}-02$ & $<5.16 \mathrm{E}-02$ & $<6.35 \mathrm{E}-02$ & $<5.45 \mathrm{E}-02$ & $<5.22 \mathrm{E}-02$ & $<5.48 \mathrm{E}-02$ & $<6.06 \mathrm{E}-02$ & $<6.35 \mathrm{E}-02$ & $<8.60 \mathrm{E}-02$ & $<8.59 \mathrm{E}-02$ & $<7.59 \mathrm{E}-02$ & $<7.64 \mathrm{E}-02$ & $<7.06 \mathrm{E}-02$ & $<7.37 \mathrm{E}-02$ \\
\hline 106 & $<5.05 \mathrm{E}-02$ & $<5.16 \mathrm{E}-02$ & $35 \mathrm{E}-02$ & $<5$ & $<5.2$ & & $<6.06 \mathrm{E}-02$ & & $<4.30 \mathrm{E}-02$ & & & 02 & & $69 \mathrm{E}-02$ \\
\hline 107 & $<3.79 \mathrm{E}-01$ & $<3.87 \mathrm{E}-01$ & $<4.76 \mathrm{E}-01$ & $<4.09 \mathrm{E}-01$ & $<3.91 \mathrm{E}-01$ & $<4.11 \mathrm{E}-01$ & $<4.55 \mathrm{E}-01$ & $<4.76 \mathrm{E}-01$ & $2.45 \mathrm{E}-01$ & $<2.36 \mathrm{E}-01$ & $<2.09 \mathrm{E}-01$ & $<2.10 \mathrm{E}-01$ & $<1.94 \mathrm{E}-01$ & $<2.03 \mathrm{E}-01$ \\
\hline 108 & $<1.01 \mathrm{E}-01$ & $<1.03 \mathrm{E}-01$ & $<1.27 \mathrm{E}-01$ & $<1.09 \mathrm{E}-01$ & $<1.04 \mathrm{E}-01$ & $<1.101$ & $<1.21 \mathrm{E}-01$ & $<1.27 \mathrm{E}-01$ & $<6.45 \mathrm{E}-02$ & $<6.44 \mathrm{E}-02$ & $<5.70 \mathrm{E}-02$ & $<5.73 \mathrm{E}-02$ & $<5.30 \mathrm{E}-02$ & $<5.53 \mathrm{E}-02$ \\
\hline 109 & & & E-01 & & $<1$ & $<1$. & & & & & & & & $1 E_{-} 01$ \\
\hline 110 & $<1.01 \mathrm{E}-01$ & $<1.03 \mathrm{E}-01$ & $<1.27 \mathrm{E}-01$ & $<1.09 \mathrm{E}-01$ & $<1.04 \mathrm{E}-01$ & $<1.10 \mathrm{E}-01$ & $<1.21 \mathrm{E}-01$ & $<1.27 \mathrm{E}-01$ & $<2.15 \mathrm{E}-02$ & $<2.15 \mathrm{E}-02$ & $<1.90 \mathrm{E}-02$ & $<1.91 \mathrm{E}-02$ & $<1.77$ & $<1.84 \mathrm{E}-02$ \\
\hline 111 & $<5.05 \mathrm{E}-02$ & $<5.16 \mathrm{E}-02$ & $<6.35 \mathrm{E}-02$ & $<5.45 \mathrm{E}-02$ & & $<5.48 \mathrm{E}-02$ & $<6.06 \mathrm{E}-02$ & $<6.35 \mathrm{E}-02$ & $<6$. & $<6$ & $<5.70 \mathrm{E}-02$ & -02 & $<5.3$ & $<5.53 \mathrm{E}-02$ \\
\hline 112 & & & & & & $6.36 \mathrm{E}-02$ & & & & & & & & -461502 \\
\hline 113 & $<6.34 \mathrm{E}+00$ & $<6.47 \mathrm{E}+00$ & $<7.97 \mathrm{E}+00$ & $<6.84 \mathrm{E}+00$ & $<6.55 \mathrm{E}+00$ & $<6.87 \mathrm{E}+00$ & $<7.61 \mathrm{E}+00$ & $<7.97 \mathrm{E}+00$ & $<3.10 \mathrm{E}+00$ & $<3.09 \mathrm{E}+00$ & $<2.73 \mathrm{E}+00$ & $<2.75 \mathrm{E}+00$ & $<2.54 \mathrm{E}+00$ & $<2.65 \mathrm{E}+00$ \\
\hline 114 & $<7.5$ & & & & & & & & & & & & & \\
\hline 116 & $1.43 \mathrm{E}-01$ & 01 & E-02 & 1 & 2 & 2 & -01 & E-02 & 02 & 9. & 02 & 02 & 02 & 7.05E-02 \\
\hline 117 & $<7.58 \mathrm{E}-02$ & $<7.74 \mathrm{E}-02$ & $<9.52 \mathrm{E}-02$ & $<8.18 \mathrm{E}-02$ & $<7.83 \mathrm{E}-02$ & $<8.21 \mathrm{E}-02$ & $<9.10 \mathrm{E}-02$ & $<9.52 \mathrm{E}-02$ & 3.39E-02 & $3.30 \mathrm{E}-02$ & $3.74 \mathrm{E}-02$ & $86 \mathrm{E}-02$ & 4.01E-02 & $3.72 \mathrm{E}-02$ \\
\hline 118 & & & & & & & & & & & & & & \\
\hline 11 & 2 & 8E-01 & $2 \mathrm{E}-02$ & 01 & $1.99 \mathrm{E}-01$ & $1.89 \mathrm{E}-01$ & 01 & $<9.52 \mathrm{E}-02$ & 104 & 1.23 & 01 & 01 & 01 & $182 \mathrm{E}-0$ \\
\hline 120 & $2.26 \mathrm{E}-01$ & 7E-01 & $5 \mathrm{E}-02$ & 01 & $1.82 \mathrm{E}-01$ & $2.20 \mathrm{E}-01$ & $1.87 \mathrm{E}-01$ & $<6.35 \mathrm{E}-02$ & 2.22E- 01 & 2.08E-01 & $1.49 \mathrm{E}-01$ & $.33 \mathrm{E}-01$ & $1.78 \mathrm{E}-01$ & $1.63 \mathrm{E}-01$ \\
\hline 121 & $9.07 \mathrm{E}-02$ & 2E-01 & $5 \mathrm{E}-02$ & $\mathrm{E}-02$ & 7E-02 & $<5.48 \mathrm{E}-02$ & & $9 \mathrm{E}-02$ & $<9.68 \mathrm{E}-02$ & $<9.66 \mathrm{E}-02$ & $<8.54 \mathrm{E}-02$ & $<8.60 \mathrm{E}-02$ & $=7.94 \mathrm{E}-02$ & $8.30 \mathrm{E}-02$ \\
\hline 122 & $<7.58 \mathrm{E}-02$ & $<7.74 \mathrm{E}-02$ & $<9.52 \mathrm{E}-02$ & $<8.18 \mathrm{E}-02$ & $<7.83 \mathrm{E}-02$ & $<8.21 \mathrm{E}-02$ & $<9.10 \mathrm{E}-02$ & $<9.52 \mathrm{E}-02$ & 2.39E-02 & 3.32E-02 & $4.11 \mathrm{E}-02$ & $2.84 \mathrm{E}-02$ & 3.62E-02 & $4.41 \mathrm{E}-$ \\
\hline 123 & $<1.77 \mathrm{E}-01$ & $<1.81 \mathrm{E}-01$ & $<2.22 \mathrm{E}-01$ & $<1.91 \mathrm{E}-01$ & $<1.83 \mathrm{E}-01$ & $<1.92 \mathrm{E}-01$ & $<2.12 \mathrm{E}-01$ & $<2.22 \mathrm{E}-01$ & $<7.53 \mathrm{E}-02$ & $<7.51 \mathrm{E}-02$ & $<6.65 \mathrm{E}-02$ & $<6.69 \mathrm{E}-02$ & $<6.18 \mathrm{E}-02$ & $<6.45 \mathrm{E}-02$ \\
\hline 124 & & $6.98 \mathrm{E}-02$ & $<6.35 \mathrm{E}-02$ & & $<5.22 \mathrm{E}-02$ & $<5.48 \mathrm{E}-02$ & $<6.06 \mathrm{E}-02$ & & & & & & & \\
\hline 125 & $<1.52 \mathrm{E}-01$ & $<1.55 \mathrm{E}-01$ & $<1.90 \mathrm{E}-01$ & $<1.64 \mathrm{E}-01$ & $<1.57 \mathrm{E}-01$ & $<1.64 \mathrm{E}-01$ & $<1.82 \mathrm{E}-01$ & $<1.90 \mathrm{E}-01$ & $<2.15 \mathrm{E}-02$ & $<2.15 \mathrm{E}-02$ & $<1.90 \mathrm{E}-02$ & $<1.91 \mathrm{E}-02$ & $<1.77 \mathrm{E}-02$ & $<1.84 \mathrm{E}-0$ \\
\hline
\end{tabular}


Table A-2. ICP-MS of acid dilutions of sludge contact tests $(\mathrm{mg} / \mathrm{L}$ ), nominal uncertainty $=\mathbf{2 0} \%$ (contd.)

\begin{tabular}{|c|c|c|c|c|c|c|c|c|c|c|c|c|c|c|c|c|}
\hline ays) & 14 & 14 & Standard 1 & 14 & 14 & 14 & 14 & Standard 2 & 14 & 14 & 21 & 21 & 21 & 21 & 21 & 21 \\
\hline glycolate $(\mathrm{g} / \mathrm{L})$ & 0 & 0 & 0 & 5 & 5 & 10 & 10 & 10 & 0.2 & 0.2 & 0 & 0 & 5 & 5 & 10 & 10 \\
\hline $\mathrm{DF}(\mathrm{mL} / \mathrm{mL})$ & 10.44 & 10.89 & 12.70 & 9.77 & 9.80 & 9.31 & 10.10 & 12.70 & 11.77 & 10.41 & 11.26 & 10.68 & 9.35 & 10.07 & 11.21 & 11.60 \\
\hline LIMS numbers & 300303331 & 300303332 & 300303333 & 300303334 & 300303335 & 300303336 & 300303337 & 300303338 & 300303339 & 300303340 & 300303355 & 300303356 & 300303357 & 300303358 & 300303359 & 300303360 \\
\hline mass $(\mathrm{m} / \mathrm{z})=59$ & $<2.09 \mathrm{E}-02$ & $<2.18 \mathrm{E}-02$ & $<2.54 \mathrm{E}-02$ & $<1.95 \mathrm{E}-02$ & $<1.96 \mathrm{E}-02$ & $<1.86 \mathrm{E}-02$ & $<2.02 \mathrm{E}-02$ & $<2.54 \mathrm{E}-02$ & $<2.35 \mathrm{E}-02$ & $<2.08 \mathrm{E}-02$ & $<2.25 \mathrm{E}-02$ & $<2.14 \mathrm{E}-02$ & $<1.87 \mathrm{E}-02$ & $<2.01 \mathrm{E}-02$ & $<2.24 \mathrm{E}-02$ & $<2.32 \mathrm{E}-02$ \\
\hline 82 & $<5.23 \mathrm{E}+00$ & $<5.45 \mathrm{E}+00$ & $<6.36 \mathrm{E}+00$ & $<4.89 \mathrm{E}+00$ & $<4.91 \mathrm{E}+00$ & $<4.67 \mathrm{E}+00$ & $<5.06 \mathrm{E}+00$ & $<6.36 \mathrm{E}+00$ & $<5.90 \mathrm{E}+00$ & $<5.22 \mathrm{E}+00$ & $<6.53 \mathrm{E}+00$ & $<6.20 \mathrm{E}+00$ & $<5.42 \mathrm{E}+00$ & $<5.84 \mathrm{E}+00$ & $<6.50 \mathrm{E}+00$ & $<6.73 \mathrm{E}+00$ \\
\hline 84 & $<4.17 \mathrm{E}-02$ & $<4.35 \mathrm{E}-02$ & $<5.08 \mathrm{E}-02$ & $<3.91 \mathrm{E}-02$ & $<3.92 \mathrm{E}-02$ & $<3.73 \mathrm{E}-02$ & $6.98 \mathrm{E}-02$ & $<5.08 \mathrm{E}-02$ & $<4.71 \mathrm{E}-02$ & $<4.17 \mathrm{E}-02$ & $<2.14 \mathrm{E}-01$ & $<2.03 \mathrm{E}-01$ & $<1.78 \mathrm{E}-01$ & $<1.91 \mathrm{E}-01$ & $<2.13 \mathrm{E}-01$ & $<2.20 \mathrm{E}-01$ \\
\hline 85 & $2.31 \mathrm{E}-01$ & $2.28 \mathrm{E}-01$ & $<8.89 \mathrm{E}-02$ & $2.15 \mathrm{E}-01$ & $2.22 \mathrm{E}-01$ & $2.41 \mathrm{E}-01$ & $2.41 \mathrm{E}-01$ & $<8.89 \mathrm{E}-02$ & $2.27 \mathrm{E}-01$ & $2.61 \mathrm{E}-01$ & $2.39 \mathrm{E}-01$ & $2.61 \mathrm{E}-01$ & $2.25 \mathrm{E}-01$ & $2.40 \mathrm{E}-01$ & $2.56 \mathrm{E}-01$ & $2.46 \mathrm{E}-01$ \\
\hline 86 & $<7.31 \mathrm{E}-02$ & $<7.62 \mathrm{E}-02$ & $<8.89 \mathrm{E}-02$ & $<6.84 \mathrm{E}-02$ & $<6.86 \mathrm{E}-02$ & $<6.52 \mathrm{E}-02$ & $<7.07 \mathrm{E}-02$ & $<8.89 \mathrm{E}-02$ & $<8.24 \mathrm{E}-02$ & $<7.29 \mathrm{E}-02$ & $<1.69 \mathrm{E}-01$ & $<1.60 \mathrm{E}-01$ & $<1.40 \mathrm{E}-01$ & $<1.51 \mathrm{E}-01$ & $<1.68 \mathrm{E}-01$ & $1.74 \mathrm{E}-01$ \\
\hline 87 & 3.64E- 01 & 3.53E-01 & $<2.54 \mathrm{E}-02$ & $3.56 \mathrm{E}-01$ & $3.65 \mathrm{E}-01$ & $3.52 \mathrm{E}-01$ & 3.34E- 01 & $<2.54 \mathrm{E}-02$ & 3.96E-01 & 3.30E-01 & $3.88 \mathrm{E}-01$ & $4.42 \mathrm{E}-01$ & $3.72 \mathrm{E}-01$ & 3.79E-01 & $4.02 \mathrm{E}-01$ & 4.16E-01 \\
\hline 88 & $<2.09 \mathrm{E}-02$ & $<2.18 \mathrm{E}-02$ & $<2.54 \mathrm{E}-02$ & $<1.95 \mathrm{E}-02$ & $<1.96 \mathrm{E}-02$ & $<1.86 \mathrm{E}-02$ & $<2.02$ E- 02 & $2.78 \mathrm{E}-02$ & $<2.35 \mathrm{E}-02$ & $<2.08 \mathrm{E}-02$ & $<1.01 \mathrm{E}-01$ & $<9.62 \mathrm{E}-02$ & $<8.42 \mathrm{E}-02$ & $<9.06 \mathrm{E}-02$ & $<1.01 \mathrm{E}-01$ & $<1.04 \mathrm{E}-01$ \\
\hline 89 & $<2.09 \mathrm{E}-02$ & $<2.18 \mathrm{E}-02$ & $<2.54 \mathrm{E}-02$ & $<1.95 \mathrm{E}-02$ & $<1.96 \mathrm{E}-02$ & $<1.86 \mathrm{E}-02$ & $<2.02 \mathrm{E}-02$ & $<2.54 \mathrm{E}-02$ & $<2.35 \mathrm{E}-02$ & $<2.08 \mathrm{E}-02$ & $<4.50 \mathrm{E}-02$ & $<4.27 \mathrm{E}-02$ & $<3.74 \mathrm{E}-02$ & $<4.03 \mathrm{E}-02$ & & $<4.64 \mathrm{E}-02$ \\
\hline 90 & $<2.09 \mathrm{E}-02$ & $<2.18 \mathrm{E}-02$ & $<2.54 \mathrm{E}-02$ & $<1.95 \mathrm{E}-02$ & $<1.96 \mathrm{E}-02$ & $<1.86 \mathrm{E}-02$ & $<2.02 \mathrm{E}-02$ & $<2.54 \mathrm{E}-02$ & $<2.35 \mathrm{E}-02$ & $<2.08 \mathrm{E}-02$ & $<2.25 \mathrm{E}-02$ & $<2.14 \mathrm{E}-02$ & $<1.87 \mathrm{E}-02$ & $<2.01 \mathrm{E}-02$ & $<2.24 \mathrm{E}-02$ & $<2.32 \mathrm{E}-02$ \\
\hline 91 & $<2.09 \mathrm{E}-02$ & $<2.18 \mathrm{E}-02$ & $<2.54 \mathrm{E}-02$ & $<1.95 \mathrm{E}-02$ & $<1.96 \mathrm{E}-02$ & $<1.86 \mathrm{E}-02$ & $<2.02 \mathrm{E}-02$ & $<2.54 \mathrm{E}-02$ & $<2.35 \mathrm{E}-02$ & $<2.08 \mathrm{E}-02$ & $<2.25 \mathrm{E}-02$ & $<2.14 \mathrm{E}-02$ & $<1.87 \mathrm{E}-02$ & $<2.01 \mathrm{E}-02$ & $<2.24 \mathrm{E}-02$ & $<2.32 \mathrm{E}-02$ \\
\hline 92 & $2.50 \mathrm{E}-01$ & $2.97 \mathrm{E}-01$ & $<5.08 \mathrm{E}-02$ & $2.79 \mathrm{E}-01$ & $2.74 \mathrm{E}-01$ & $2.54 \mathrm{E}-01$ & $2.55 \mathrm{E}-01$ & $<5.08 \mathrm{E}-02$ & $2.77 \mathrm{E}-01$ & $2.69 \mathrm{E}-01$ & $2.82 \mathrm{E}-01$ & $3.03 \mathrm{E}-01$ & $2.77 \mathrm{E}-01$ & $2.57 \mathrm{E}-01$ & & $3.24 \mathrm{E}-01$ \\
\hline 93 & $<2.09 \mathrm{E}-02$ & $<2.18 \mathrm{E}-02$ & $<2.54 \mathrm{E}-02$ & $<1.95 \mathrm{E}-02$ & $<1.96 \mathrm{E}-02$ & $<1.86 \mathrm{E}-02$ & $<2.02$ E- 02 & $<2.54 \mathrm{E}-02$ & $<2.35 \mathrm{E}-02$ & $<2.08 \mathrm{E}-02$ & $<2.25 \mathrm{E}-02$ & $<2.14 \mathrm{E}-02$ & $<1.87 \mathrm{E}-02$ & $<2.01 \mathrm{E}-02$ & $<2.24 \mathrm{E}-02$ & $<2.32 \mathrm{E}-02$ \\
\hline 94 & $1.76 \mathrm{E}-01$ & & $<2.54 \mathrm{E}-02$ & & & & $1.80 \mathrm{E}-01$ & $<2.54 \mathrm{E}-02$ & & & & & & & & $1.70 \mathrm{E}-01$ \\
\hline 95 & $E+00$ & $8+0$ & $3.97 \mathrm{E}-02$ & 00 & 00 & 00 & $1.08 \mathrm{E}+00$ & $<2.54 \mathrm{E}-02$ & -00 & +00 & & & & & & $\mathrm{E}+00$ \\
\hline 96 & $3.28 \mathrm{E}-01$ & E-01 & $5.80 \mathrm{E}-02$ & 01 & & -01 & 3.47E- 01 & $<2.54 \mathrm{E}-02$ & & -01 & & & & & & $22 \mathrm{E}-01$ \\
\hline 97 & E-01 & $\mathrm{E}-01$ & $<2.54 \mathrm{E}-02$ & & & & $25 \mathrm{E}-01$ & $<2$ & & & & & & & & $\mathrm{E}-01$ \\
\hline 98 & $1.13 \mathrm{E}+00$ & $1.25 \mathrm{E}+00$ & 7.72E-02 & -00 & $1.21 \mathrm{E}+00$ & -00 & $1.17 \mathrm{E}+00$ & $<2.54 \mathrm{E}-02$ & 1.0 & $1.14 \mathrm{E}+00$ & 1.2 & $1.1 \mathrm{c}$ & & & & $1.28 \mathrm{E}+00$ \\
\hline 99 & E-01 & $9.07 \mathrm{E}-01$ & $<3.81 \mathrm{E}-02$ & 01 & 01 & 01 & $\mathrm{E}-01$ & $<3.81 \mathrm{E}-02$ & 01 & E-01 & 9.4 & 9.3 & & -01 & +00 & $1.00 \mathrm{E}+00$ \\
\hline 100 & +00 & +00 & $<2.54 \mathrm{E}-02$ & & 0 & 00 & E-01 & $\mathrm{E}-02$ & & & & & & & & $1.07 \mathrm{E}+00$ \\
\hline 101 & E-01 & E-01 & $<2.54 \mathrm{E}-02$ & & & & $\mathrm{E}-01$ & $<2.54 \mathrm{E}-02$ & & & & & & & & $9.12 \mathrm{E}-01$ \\
\hline 102 & $6 \mathrm{E}-01$ & E-01 & $<2.54 \mathrm{E}-02$ & & & 01 & E-01 & $<2.54 \mathrm{E}-02$ & & $.16 \mathrm{E}-01$ & & & & & & $8.94 \mathrm{E}-01$ \\
\hline 103 & E-01 & E-01 & $<2.54 \mathrm{E}-02$ & 01 & 01 & 01 & -01 & $<2.54 \mathrm{E}-02$ & 01 & -01 & -01 & & 01 & & & $.82 \mathrm{E}-01$ \\
\hline 104 & 2E-01 & 0E-01 & $<2.54 \mathrm{E}-02$ & 01 & 01 & 01 & -01 & $<2.54 \mathrm{E}-02$ & & & & & & & & $.52 \mathrm{E}-01$ \\
\hline 105 & $<2.09 \mathrm{E}-02$ & $<2.18 \mathrm{E}-02$ & $<2.54 \mathrm{E}-02$ & $<1.95 \mathrm{E}-02$ & $<1.96 \mathrm{E}-02$ & $<1.86 \mathrm{E}-02$ & $<2.02 \mathrm{E}-02$ & $<2.54 \mathrm{E}-02$ & $<2.35 \mathrm{E}-02$ & $<2.08 \mathrm{E}-02$ & $<4.50 \mathrm{E}-02$ & $<4.27 \mathrm{E}-02$ & $<3.74 \mathrm{E}-02$ & $<4.03 \mathrm{E}-02$ & $<4.48 \mathrm{E}-02$ & $<4.64 \mathrm{E}-02$ \\
\hline 106 & $<3.13 \mathrm{E}-02$ & $<3.27 \mathrm{E}-02$ & $<3.81 \mathrm{E}-02$ & $<2.93 \mathrm{E}-02$ & $<2.94 \mathrm{E}-02$ & $<2.79 \mathrm{E}-02$ & $<3.03 \mathrm{E}-02$ & $\mathrm{E}-02$ & $<3.9$ & $<3.12 \mathrm{E}-02$ & $<2.2$ & $<2$. & & & $<2.24$ & $<2.32 \mathrm{E}-02$ \\
\hline 107 & $6.96 \mathrm{E}-02$ & $<6.53 \mathrm{E}-02$ & $<7.62 \mathrm{E}-02$ & $<5.86 \mathrm{E}-02$ & $<5.88 \mathrm{E}-02$ & $<5.59 \mathrm{E}-02$ & $<6.06 \mathrm{E}-02$ & $<7.62 \mathrm{E}-02$ & $<7.06 \mathrm{E}-02$ & $<6.25 \mathrm{E}-02$ & & 9.5 & E-02 & $<5$. & $<5.60 \mathrm{E}-02$ & $<5.80 \mathrm{E}-02$ \\
\hline 108 & $<2.09 \mathrm{E}-02$ & $<2.18 \mathrm{E}-02$ & $<2.54 \mathrm{E}-02$ & $<1.95 \mathrm{E}-02$ & $<1.96 \mathrm{E}-02$ & $<1.86 \mathrm{E}-02$ & $<2.02 \mathrm{E}-02$ & $<2.54 \mathrm{E}-02$ & $<2.35 \mathrm{E}-02$ & $<2.08 \mathrm{E}-02$ & $<2.25 \mathrm{E}-02$ & $<2.14 \mathrm{E}-02$ & $<1.87 \mathrm{E}-02$ & $<2.01 \mathrm{E}-02$ & $<2.24 \mathrm{E}-02$ & $<2.32 \mathrm{E}-02$ \\
\hline 109 & 2E-02 & & $<3.81 \mathrm{E}-02$ & & & & & & & & & & & & & $<6.96 \mathrm{E}-02$ \\
\hline 110 & $<2.09 \mathrm{E}-02$ & $<2.18 \mathrm{E}-02$ & $<2.54 \mathrm{E}-02$ & $<1.95 \mathrm{E}-02$ & $<1.96 \mathrm{E}-02$ & $<1.86 \mathrm{E}-02$ & $<2.02 \mathrm{E}-02$ & $<2.54 \mathrm{E}-02$ & $<2.35 \mathrm{E}-02$ & $<2.08 \mathrm{E}-02$ & $<2$. & $<2.14 \mathrm{E}-02$ & -02 & $<2$ & $<2.2$ & $<2.32 \mathrm{E}-02$ \\
\hline 111 & $<2.09 \mathrm{E}-02$ & $<2.18 \mathrm{E}-02$ & $<2.54 \mathrm{E}-02$ & $<1.95 \mathrm{E}-02$ & $<1.96 \mathrm{E}-02$ & $<1.86 \mathrm{E}-02$ & $<2.02 \mathrm{E}-02$ & $<2.54 \mathrm{E}-02$ & $<2.35 \mathrm{E}-02$ & $<2.08 \mathrm{E}-02$ & $<2.25$ & 2.2 & 8-02 & $<2$. & $<2.2$ & $<2.32 \mathrm{E}-02$ \\
\hline 112 & & & $<2.54 \mathrm{E}-02$ & & & & & & & & & & & & & \\
\hline 113 & $<1.62 \mathrm{E}+00$ & $<1.69 \mathrm{E}+00$ & $<1.97 \mathrm{E}+00$ & $<1.51 \mathrm{E}+00$ & $<1.52 \mathrm{E}+00$ & $<1.44 \mathrm{E}+00$ & $<1.57 \mathrm{E}+00$ & $<1.97 \mathrm{E}+00$ & $<1.82 \mathrm{E}+00$ & $<1.61 \mathrm{E}+00$ & $<1.31 \mathrm{E}+00$ & $<1.24 \mathrm{E}+00$ & $<1.08 \mathrm{E}+00$ & $<1.17 \mathrm{E}+00$ & $<1.30 \mathrm{E}+00$ & $<1.35 \mathrm{E}+00$ \\
\hline 114 & & & & & & & & & & & & & & & & \\
\hline 116 & E- -02 & 12 & $<2$ & & & & 02 & 02 & & & & & & & 7.9 & $\mathrm{E}-02$ \\
\hline 117 & E-02 & E-02 & $<2.54 \mathrm{E}-02$ & 3 & 3 & & E-02 & $\mathrm{E}-02$ & & & & & & & $4.36 \mathrm{E}-02$ & $3.96 \mathrm{E}-02$ \\
\hline 118 & & & $<2.54 \mathrm{E}-02$ & & & & & & & & & & & & & 25E-01 \\
\hline 119 & & & $<2.54 \mathrm{E}-02$ & & & & & $\mathrm{E}-02$ & & & & & & & & $7 \mathrm{E}-01$ \\
\hline 120 & $1.90 \mathrm{E}-01$ & $1.61 \mathrm{E}-01$ & $<2.54 \mathrm{E}-02$ & $1.51 \mathrm{E}-01$ & $1.71 \mathrm{E}-01$ & $1.53 \mathrm{E}-01$ & $1.67 \mathrm{E}-01$ & $<2.54 \mathrm{E}-02$ & $1.70 \mathrm{E}-01$ & $1.81 \mathrm{E}-01$ & & $2.01 \mathrm{E}-01$ & E-01 & E-01 & $1.56 \mathrm{E}-01$ & $71 \mathrm{E}-01$ \\
\hline 121 & $<3$. & $<3$ & -02 & & & & & & & & & & $8-02$ & & $<8.96 \mathrm{E}-02$ & $<9.28 \mathrm{E}-02$ \\
\hline 122 & 3.33E-02 & $3.39 \mathrm{E}-02$ & $<2.54 \mathrm{E}-02$ & $4.85 \mathrm{E}-02$ & $3.24 \mathrm{E}-02$ & $3.15 \mathrm{E}-02$ & $3.50 \mathrm{E}-02$ & $<2.54 \mathrm{E}-02$ & 3.65E-02 & $3.71 \mathrm{E}-02$ & $2.56 \mathrm{E}-02$ & $3.83 \mathrm{E}-02$ & $3.98 \mathrm{E}-02$ & $2.92 \mathrm{E}-02$ & $4.04 \mathrm{E}-02$ & $3.89 \mathrm{E}-02$ \\
\hline 123 & $<4.17 \mathrm{E}-02$ & $<4.35 \mathrm{E}-02$ & $<5.08 \mathrm{E}-02$ & $<3.91 \mathrm{E}-02$ & $<3.92 \mathrm{E}-02$ & $<3.73 \mathrm{E}-02$ & $<4.04 \mathrm{E}-02$ & $8 \mathrm{E}-02$ & $<4.71 \mathrm{E}-02$ & $<4.17 \mathrm{E}-02$ & $<3.38 \mathrm{E}-02$ & $3.21 \mathrm{E}-02$ & $<2.81 \mathrm{E}-02$ & $=3.02 \mathrm{E}-02$ & $<3.36 \mathrm{E}-02$ & 3.48E-02 \\
\hline 124 & & & -02 & & & & $\mathrm{E}-02$ & $\mathrm{E}-102$ & & & & & $\mathrm{E}-02$ & & & \\
\hline 125 & $<4.17 \mathrm{E}-02$ & $<4.35 \mathrm{E}-02$ & $<5.08 \mathrm{E}-02$ & $<3.91 \mathrm{E}-02$ & $<3.92 \mathrm{E}-02$ & $<3.73 \mathrm{E}-02$ & $<4.04 \mathrm{E}-02$ & $<5.08 \mathrm{E}-02$ & $<4.71 \mathrm{E}-02$ & $<4.17 \mathrm{E}-02$ & $<2.25 \mathrm{E}-02$ & $<2.14 \mathrm{E}-02$ & $<1.87 \mathrm{E}-02$ & $<2.01 \mathrm{E}-02$ & $<2.24 \mathrm{E}-02$ & $<2.32 \mathrm{E}-02$ \\
\hline
\end{tabular}


Table A-2. ICP-MS of acid dilutions of sludge contact tests $(\mathrm{mg} / \mathrm{L}$ ), nominal uncertainty $=\mathbf{2 0} \%$ (contd.)

\begin{tabular}{|c|c|c|c|c|c|c|c|c|c|c|c|c|c|c|c|c|}
\hline ays) & 35 & 35 & Standard 1 & 35 & 35 & 35 & 35 & Standard 2 & 35 & 35 & 35 & 35 & 35 & 35 & 35 & 35 \\
\hline glycolate $(\mathrm{g} / \mathrm{L})$ & 0 & 0 & 0 & 5 & 5 & 10 & 10 & 10 & 0.2 & 0.2 & 0 & 0 & 5 & 5 & 10 & 10 \\
\hline $\mathrm{DF}(\mathrm{mL} / \mathrm{mL})$ & 10.74 & 9.26 & 12.70 & 11.78 & 10.95 & 12.04 & 10.23 & 12.70 & 9.45 & 12.27 & 10.65 & 10.91 & 11.65 & 10.58 & 10.65 & 12.28 \\
\hline LIMS numbers & 300303385 & 300303386 & 300303387 & 300303388 & 300303389 & 300303390 & 300303391 & 300303392 & 300303393 & 300303394 & 300303395 & 300303396 & 300303397 & 300303398 & 300303399 & 300303400 \\
\hline mass $(\mathrm{m} / \mathrm{z})=59$ & $<2.15 \mathrm{E}-02$ & $<1.85 \mathrm{E}-02$ & $<2.54 \mathrm{E}-02$ & $<2.36 \mathrm{E}-02$ & $<2.19 \mathrm{E}-02$ & $<2.41 \mathrm{E}-02$ & $<2.05 \mathrm{E}-02$ & $<2.54 \mathrm{E}-02$ & $<1.89 \mathrm{E}-02$ & $<2.45 \mathrm{E}-02$ & $<3.19 \mathrm{E}-02$ & $<3.27 \mathrm{E}-02$ & $<3.50 \mathrm{E}-02$ & $<3.18 \mathrm{E}-02$ & $<3.19 \mathrm{E}-02$ & $<3.68 \mathrm{E}-02$ \\
\hline 82 & $<4.02 \mathrm{E}+00$ & $<3.46 \mathrm{E}+00$ & $<4.75 \mathrm{E}+00$ & $<4.41 \mathrm{E}+00$ & $<4.10 \mathrm{E}+00$ & $<4.50 \mathrm{E}+00$ & $<3.83 \mathrm{E}+00$ & $<4.75 \mathrm{E}+00$ & $<3.54 \mathrm{E}+00$ & $<4.59 \mathrm{E}+00$ & $<2.04 \mathrm{E}+00$ & $<2.09 \mathrm{E}+00$ & $<2.24 \mathrm{E}+00$ & $<2.03 \mathrm{E}+00$ & $<2.04 \mathrm{E}+00$ & $<2.36 \mathrm{E}+00$ \\
\hline 84 & $<2.26 \mathrm{E}-01$ & $<1.94 \mathrm{E}-01$ & $<2.67 \mathrm{E}-01$ & $<2.47 \mathrm{E}-01$ & $<2.30 \mathrm{E}-01$ & $<2.53 \mathrm{E}-01$ & $<2.15 \mathrm{E}-01$ & $<2.67 \mathrm{E}-01$ & $<1.99 \mathrm{E}-01$ & $<2.58 \mathrm{E}-01$ & $<3.73 \mathrm{E}-01$ & $<3.82 \mathrm{E}-01$ & $<4.08 \mathrm{E}-01$ & $<3.70 \mathrm{E}-01$ & $<3.73 \mathrm{E}-01$ & $<4.30 \mathrm{E}-01$ \\
\hline 85 & $2.61 \mathrm{E}-01$ & $2.27 \mathrm{E}-01$ & $<3.81 \mathrm{E}-02$ & $2.30 \mathrm{E}-01$ & $2.45 \mathrm{E}-01$ & 2.42E-01 & $2.27 \mathrm{E}-01$ & $<3.81 \mathrm{E}-02$ & $2.29 \mathrm{E}-01$ & $2.59 \mathrm{E}-01$ & $2.40 \mathrm{E}-01$ & $2.54 \mathrm{E}-01$ & $2.31 \mathrm{E}-01$ & $2.63 \mathrm{E}-01$ & $2.48 \mathrm{E}-01$ & $2.93 \mathrm{E}-01$ \\
\hline 86 & $<4.30 \mathrm{E}-01$ & $<3.70 \mathrm{E}-01$ & $<5.08 \mathrm{E}-01$ & $<4.71 \mathrm{E}-01$ & $<4.38 \mathrm{E}-01$ & $<4.82 \mathrm{E}-01$ & $<4.09 \mathrm{E}-01$ & $<5.08 \mathrm{E}-01$ & $<3.78 \mathrm{E}-01$ & $<4.91 \mathrm{E}-01$ & $<1.06 \mathrm{E}-01$ & $<1.09 \mathrm{E}-01$ & $<1.17 \mathrm{E}-01$ & $<1.06 \mathrm{E}-01$ & $<1.06 \mathrm{E}-01$ & $1.23 \mathrm{E}-01$ \\
\hline 87 & $3.98 \mathrm{E}-01$ & $3.68 \mathrm{E}-01$ & $<2.54 \mathrm{E}-02$ & 4.06E- 01 & 3.93E-01 & $3.75 \mathrm{E}-01$ & $3.75 \mathrm{E}-01$ & $<2.54 \mathrm{E}-02$ & 3.93E-01 & $3.77 \mathrm{E}-01$ & $3.47 \mathrm{E}-01$ & $3.82 \mathrm{E}-01$ & 3.54E- 01 & 4.26E-01 & $3.67 \mathrm{E}-01$ & $3.49 \mathrm{E}-01$ \\
\hline 88 & $<2.15 \mathrm{E}-02$ & $<1.85 \mathrm{E}-02$ & 3.44E-02 & $<2.36 \mathrm{E}-02$ & $<2.19 \mathrm{E}-02$ & $<2.41 \mathrm{E}-02$ & $<2.05 \mathrm{E}-02$ & 3.44E- 02 & $<1.89 \mathrm{E}-02$ & $<2.45 \mathrm{E}-02$ & $<2.13 \mathrm{E}-02$ & $<2.18 \mathrm{E}-02$ & $<2.33 \mathrm{E}-02$ & $<2.12 \mathrm{E}-02$ & $<4.00 \mathrm{E}-02$ & $<2.46 \mathrm{E}-02$ \\
\hline 89 & $<2.15 \mathrm{E}-02$ & $<1.85 \mathrm{E}-02$ & $<2.54 \mathrm{E}-02$ & $<2.36 \mathrm{E}-02$ & $<2.19 \mathrm{E}-02$ & $<2.41 \mathrm{E}-02$ & $<2.05 \mathrm{E}-02$ & $<2.54 \mathrm{E}-02$ & $<1.89 \mathrm{E}-02$ & $<2.45 \mathrm{E}-02$ & $<2.1$ & $<2.18 \mathrm{E}-02$ & $<2.33 \mathrm{E}-02$ & $<2.12 \mathrm{E}-02$ & & $<2.46 \mathrm{E}-02$ \\
\hline 90 & $<2.15 \mathrm{E}-02$ & $<1.85 \mathrm{E}-02$ & $3.25 \mathrm{E}-02$ & $<2.36 \mathrm{E}-02$ & $<2.19 \mathrm{E}-02$ & $<2.41 \mathrm{E}-02$ & $<2.05 \mathrm{E}-02$ & $<2.54 \mathrm{E}-02$ & $<1.89 \mathrm{E}-02$ & $<2.45 \mathrm{E}-02$ & $<3.19 \mathrm{E}-02$ & $<3.27 \mathrm{E}-02$ & $<3.50 \mathrm{E}-02$ & $<3.18 \mathrm{E}-02$ & $<3.19 \mathrm{E}-02$ & $<3.68 \mathrm{E}-02$ \\
\hline 91 & $<2.15 \mathrm{E}-02$ & $<1.85 \mathrm{E}-02$ & $<2.54 \mathrm{E}-02$ & $<2.36 \mathrm{E}-02$ & $<2.19 \mathrm{E}-02$ & $<2.41 \mathrm{E}-02$ & $<2.05 \mathrm{E}-02$ & $<2.54 \mathrm{E}-02$ & $<1.89 \mathrm{E}-02$ & $<2.45 \mathrm{E}-02$ & $<2.13 \mathrm{E}-02$ & $<2.18 \mathrm{E}-02$ & $<2.33 \mathrm{E}-02$ & $<2.12 \mathrm{E}-02$ & $<2.13$ & $<2.46 \mathrm{E}-02$ \\
\hline 92 & $2.58 \mathrm{E}-01$ & $2.71 \mathrm{E}-01$ & $<7.62 \mathrm{E}-02$ & $2.97 \mathrm{E}-01$ & $2.88 \mathrm{E}-01$ & $3.18 \mathrm{E}-01$ & $2.86 \mathrm{E}-01$ & $<7.62 \mathrm{E}-02$ & $2.90 \mathrm{E}-01$ & 3.47E-01 & & & & & & $3.09 \mathrm{E}-01$ \\
\hline 93 & $<5.37 \mathrm{E}-02$ & $<4.63 \mathrm{E}-02$ & $<6.35 \mathrm{E}-02$ & $<5.89 \mathrm{E}-02$ & $<5.48 \mathrm{E}-02$ & $<6.02 \mathrm{E}-02$ & $<5.11 \mathrm{E}-02$ & $<6.35 \mathrm{E}-02$ & $<4.73 \mathrm{E}-02$ & $<6.13 \mathrm{E}-02$ & $<3.19 \mathrm{E}-02$ & $<3.27 \mathrm{E}-02$ & $<3.50 \mathrm{E}-02$ & $<3.18 \mathrm{E}-02$ & $<3.19 \mathrm{E}-02$ & $<3.68 \mathrm{E}-02$ \\
\hline 94 & $1.98 \mathrm{E}-01$ & & & & & & & & & & & & & & & $1.99 \mathrm{E}-01$ \\
\hline 95 & $E+00$ & 1. & $\mathrm{E}-02$ & 1. & 00 & 00 & +00 & $<3.81 \mathrm{E}-02$ & 1.18 & -00 & & & & & & $\mathrm{E}+00$ \\
\hline 96 & $3.47 \mathrm{E}-01$ & E-01 & $6.00 \mathrm{E}-02$ & & 01 & -01 & 3.52E- 01 & $<3.81 \mathrm{E}-02$ & 3.15 & & & & & & & $8 \mathrm{E}-01$ \\
\hline 97 & E-01 & 8.86E-01 & $<3.81 \mathrm{E}-02$ & & 1.0 & $1.02 \mathrm{E}+00$ & $\mathrm{E}-01$ & $<3.8$ & $9.76 \mathrm{E}-01$ & $E+00$ & & & & & & \\
\hline 98 & $1.31 \mathrm{E}+00$ & $1.19 \mathrm{E}+00$ & 7.81E-02 & -00 & $1.28 \mathrm{E}+00$ & $1.32 \mathrm{E}+00$ & $1.21 \mathrm{E}+00$ & $<3.81 \mathrm{E}-02$ & $1.23 \mathrm{E}+00$ & $1.29 \mathrm{E}+00$ & 1.25 & 1.24 & $1.22 \mathrm{E}+00$ & & & $1.22 \mathrm{E}+00$ \\
\hline 99 & $9.54 \mathrm{E}-01$ & $9.94 \mathrm{E}-01$ & $<2.54 \mathrm{E}-02$ & E-01 & $9.67 \mathrm{E}-01$ & 01 & $1.01 \mathrm{E}+00$ & $<2.54 \mathrm{E}-02$ & 8.9 & $9.08 \mathrm{E}-01$ & 9.5 & 9.7 & +00 & & +00 & $9.43 \mathrm{E}-01$ \\
\hline 100 & $1.02 \mathrm{E}+00$ & E-01 & $3.98 \mathrm{E}-02$ & & & & $E+00$ & $\mathrm{E}-02$ & 1.0 & & & & & & & $1.06 \mathrm{E}+00$ \\
\hline 101 & E-01 & E-01 & $<2.54 \mathrm{E}-02$ & & & & E-01 & $<2.54 \mathrm{E}-02$ & & E-01 & & & & & & $1.08 \mathrm{E}+00$ \\
\hline 102 & $8.49 \mathrm{E}-01$ & IE- 01 & $<3.81 \mathrm{E}-02$ & & $\mathrm{E}-01$ & $1.19 \mathrm{E}+00$ & $9.50 \mathrm{E}-01$ & $<3.81 \mathrm{E}-02$ & 7.59 & $.09 \mathrm{E}-01$ & & 8.2 & & & & $9.64 \mathrm{E}-01$ \\
\hline 103 & IE-01 & E- 01 & $<3.81 \mathrm{E}-02$ & 01 & E-01 & $3.77 \mathrm{E}-01$ & 37E-01 & $<3.81 \mathrm{E}-02$ & 01 & $E-01$ & & & & & 01 & 4.89E-01 \\
\hline 104 & EE-01 & 0E-01 & $<2.54 \mathrm{E}-02$ & 1 & 01 & 01 & 01 & -02 & & & & & & & & $54 \mathrm{E}-01$ \\
\hline 105 & $<2.15 \mathrm{E}-02$ & $<1.85 \mathrm{E}-02$ & $<2.54 \mathrm{E}-02$ & $<2.36 \mathrm{E}-02$ & $<2.19 \mathrm{E}-02$ & $<2.41 \mathrm{E}-02$ & $<2.05 \mathrm{E}-02$ & $<2.54 \mathrm{E}-02$ & $<1.89 \mathrm{E}-02$ & $<2.45 \mathrm{E}-02$ & $<2.1$ & $<2.18 \mathrm{E}-02$ & $<2.33 \mathrm{E}-02$ & $<2.12 \mathrm{E}-02$ & $=3.97 \mathrm{E}-02$ & $<2.46 \mathrm{E}-02$ \\
\hline 106 & $<4.30 \mathrm{E}-02$ & $<3.70 \mathrm{E}-02$ & $<5.08 \mathrm{E}-02$ & $<4.7$ & $<4.38 \mathrm{E}-02$ & $<4.82 \mathrm{E}-02$ & $<4.09 \mathrm{E}-02$ & & $<3.78$ & $<4.91 \mathrm{E}-02$ & $<2$. & 02 & & & & $<2.46 \mathrm{E}-02$ \\
\hline 107 & E-01 & $1.07 \mathrm{E}-01$ & $<7.62 \mathrm{E}-02$ & $<7.07 \mathrm{E}-02$ & $<6.57 \mathrm{E}-02$ & $<7.22 \mathrm{E}-02$ & $<6.14 \mathrm{E}-02$ & $<7.62 \mathrm{E}-02$ & 1.2 & E-02 & & 8.7 & $<2$ & $<2$ & $<2$ & $<2.46 \mathrm{E}-02$ \\
\hline 108 & $<3.22 \mathrm{E}-02$ & $<2.78 \mathrm{E}-02$ & $<3.81 \mathrm{E}-02$ & $<3.53 \mathrm{E}-02$ & $<3.29 \mathrm{E}-02$ & $<3.61 \mathrm{E}-02$ & $<3.07 \mathrm{E}-02$ & $<3.81 \mathrm{E}-02$ & $<2.84 \mathrm{E}-02$ & $<3.68 \mathrm{E}-02$ & $<2.13 \mathrm{E}-02$ & $<2.18 \mathrm{E}-02$ & $<2.33 \mathrm{E}-02$ & $<2.12 \mathrm{E}-02$ & $<2.13 \mathrm{E}-02$ & $<2.46 \mathrm{E}-02$ \\
\hline 109 & & & & & & & $\mathrm{E}-02$ & & & & & & & & & $<2.46 \mathrm{E}-02$ \\
\hline 110 & $<2.15 \mathrm{E}-02$ & E- 02 & $<2.54 \mathrm{E}-02$ & $<2.36 \mathrm{E}-02$ & $<2.19 \mathrm{E}-02$ & $<2.41 \mathrm{E}-02$ & $<2.05 \mathrm{E}-02$ & $\mathrm{E}-02$ & $<1.89 \mathrm{E}-02$ & $<2.45 \mathrm{E}-02$ & $<2$. & $<2.1$ & -02 & $<2$ & -02 & $<2.46 \mathrm{E}-02$ \\
\hline 111 & $<2.15 \mathrm{E}-02$ & $<1.85 \mathrm{E}-02$ & $<2.54 \mathrm{E}-02$ & $<2.36 \mathrm{E}-02$ & $<2.19 \mathrm{E}-02$ & $<2.41 \mathrm{E}-02$ & $<2.05 \mathrm{E}-02$ & $<2.54 \mathrm{E}-02$ & $<1.89 \mathrm{E}-02$ & $<2.45 \mathrm{E}-02$ & $<2.1$ & $<2.18$ & $<2.3$ & $<2.1$ & -02 & $<2.46 \mathrm{E}-02$ \\
\hline 112 & & & $<2.54 \mathrm{E}-02$ & $<2.36 \mathrm{E}-02$ & & & & & & & & & & & & $246=0$ \\
\hline 113 & $<1.01 \mathrm{E}+00$ & $<8.71 \mathrm{E}-01$ & $<1.19 \mathrm{E}+00$ & $<1.11 \mathrm{E}+00$ & $<1.03 \mathrm{E}+00$ & $<1.13 \mathrm{E}+00$ & $<9.61 \mathrm{E}-01$ & $<1.19 \mathrm{E}+00$ & $<8.89 \mathrm{E}-01$ & $<1.15 \mathrm{E}+00$ & $<1.70 \mathrm{E}+00$ & $<1.75 \mathrm{E}+00$ & $<1.86 \mathrm{E}+00$ & $<1.69 \mathrm{E}+00$ & $<1.70 \mathrm{E}+00$ & $<1.96 \mathrm{E}+00$ \\
\hline 114 & & & & $<2.3$ & & & & & & & & & & & & \\
\hline 116 & 2 & & $<2$ & 8 & & & 02 & 02 & & & & & & & & $6.68 \mathrm{E}-02$ \\
\hline 117 & E-02 & E-02 & $<2.54 \mathrm{E}-02$ & & & & $\mathrm{E}-02$ & $8-02$ & & & & & & & $8-02$ & $3.73 \mathrm{E}-02$ \\
\hline 118 & & & $<2.54 \mathrm{E}-02$ & & & & & & & & & & & & & $.22 \mathrm{E}-01$ \\
\hline 119 & & & $<2.54 \mathrm{E}-02$ & & & & & $\mathrm{E}-02$ & & & & & & & & $1.22 \mathrm{E}-01$ \\
\hline 120 & 2.14E-01 & $1.95 \mathrm{E}-01$ & $<2.54 \mathrm{E}-02$ & $1.95 \mathrm{E}-01$ & $1.56 \mathrm{E}-01$ & $1.82 \mathrm{E}-01$ & $\mathrm{E}-01$ & $\mathrm{E}-02$ & $1.79 \mathrm{E}-01$ & $2.02 \mathrm{E}-01$ & & 1.72 & E-01 & E-01 & $8-01$ & $.48 \mathrm{E}-01$ \\
\hline 121 & $<4.3$ & & -02 & & & & & & $<3.7$ & & & & & $<5.2$ & & $<6.14 \mathrm{E}-02$ \\
\hline 122 & $3.71 \mathrm{E}-02$ & $3.53 \mathrm{E}-02$ & $<2.54 \mathrm{E}-02$ & 4.42E- 02 & $2.92 \mathrm{E}-02$ & $3.87 \mathrm{E}-02$ & $5.18 \mathrm{E}-02$ & $<2.54 \mathrm{E}-02$ & 4.66E- 02 & $3.01 \mathrm{E}-02$ & $4.26 \mathrm{E}-02$ & $<4.36 \mathrm{E}-02$ & $<4.66 \mathrm{E}-02$ & $<4.23 \mathrm{E}-02$ & $4.56 \mathrm{E}-02$ & $<4.91 \mathrm{E}-02$ \\
\hline 123 & $<2.15 \mathrm{E}-02$ & $<1.85 \mathrm{E}-02$ & $<2.54 \mathrm{E}-02$ & $<2.36 \mathrm{E}-02$ & $<2.19 \mathrm{E}-02$ & $<2.41 \mathrm{E}-02$ & $<2.05 \mathrm{E}-02$ & 54E- 02 & $<1.89 \mathrm{E}-02$ & $<2.45 \mathrm{E}-02$ & & -02 & & $4.23 \mathrm{E}-02$ & $<4.26 \mathrm{E}-02$ & $<4.91 \mathrm{E}-02$ \\
\hline 124 & & & -02 & & & & & $<$ & & & -02 & $<5.4$ & $<5.88 \mathrm{E}-02$ & $<5.29 \mathrm{E}-02$ & & $<6.14 \mathrm{E}-02$ \\
\hline 125 & $<2.15 \mathrm{E}-02$ & $<1.85 \mathrm{E}-02$ & $<2.54 \mathrm{E}-02$ & $<2.36 \mathrm{E}-02$ & $<2.19 \mathrm{E}-02$ & $<2.41 \mathrm{E}-02$ & $<2.05 \mathrm{E}-02$ & $<2.54 \mathrm{E}-02$ & $<1.89 \mathrm{E}-02$ & $<2.45 \mathrm{E}-02$ & $<8.52 \mathrm{E}-02$ & $<8.73 \mathrm{E}-02$ & $<9.32 \mathrm{E}-02$ & $<8.47 \mathrm{E}-02$ & $<8.52 \mathrm{E}-02$ & $<9.82 \mathrm{E}-02$ \\
\hline
\end{tabular}


Table A-2. ICP-MS of acid dilutions of sludge contact tests (mg/L), nominal uncertainty $=20 \%$ (contd.)

\begin{tabular}{|c|c|c|c|c|c|c|c|c|c|c|c|c|c|c|}
\hline lays) & 0 & 0 & tandard 1 & 0 & 0 & 0 & 0 & Standard 2 & 7 & 7 & 7 & 7 & 1 & 7 \\
\hline$(g / L)$ & 0 & 0 & 0 & 5 & 5 & 10 & 10 & 10 & 0 & 0 & 5 & 5 & 10 & 10 \\
\hline $\mathrm{DF}(\mathrm{mL} / \mathrm{mL})$ & 10.11 & 10.32 & 12.70 & 10.90 & 10.44 & 10.95 & 12.13 & 2.70 & 10.75 & 10.73 & 9.49 & 9.55 & 8.83 & 9.22 \\
\hline LIMS numbers & 300303312 & 300303313 & 300303314 & 300303315 & 300303316 & 300303317 & 300303318 & 300303319 & 300303297 & 300303298 & 300303299 & 300303300 & 300303301 & 300303302 \\
\hline $\operatorname{mass}(\mathrm{m} / \mathrm{z})=126$ & $<1.52 \mathrm{E}-01$ & $<1.55 \mathrm{E}-01$ & $<1.90 \mathrm{E}-01$ & $<1.64 \mathrm{E}-01$ & $<1.57 \mathrm{E}-01$ & $<1.64 \mathrm{E}-01$ & $<1.82 \mathrm{E}-01$ & $<1.90 \mathrm{E}-01$ & $<1.18 \mathrm{E}-01$ & $<1.18 \mathrm{E}-01$ & $<1.04 \mathrm{E}-01$ & $<1.05 \mathrm{E}-01$ & $<9.71 \mathrm{E}-02$ & $<1.01 \mathrm{E}-01$ \\
\hline 128 & $<6.06 \mathrm{E}-01$ & $<6.19 \mathrm{E}-01$ & $<7.62 \mathrm{E}-01$ & $<6.54 \mathrm{E}-01$ & $<6.26 \mathrm{E}-01$ & $<6.57 \mathrm{E}-01$ & $<7.28 \mathrm{E}-01$ & $<7.62 \mathrm{E}-01$ & $<3.87 \mathrm{E}-01$ & $<3.86 \mathrm{E}-01$ & $<3.42 \mathrm{E}-01$ & $<3.44 \mathrm{E}-01$ & $<3.18 \mathrm{E}-01$ & $<3.32 \mathrm{E}-01$ \\
\hline 130 & $<1.49 \mathrm{E}+00$ & $<1.52 \mathrm{E}+00$ & $<1.87 \mathrm{E}+00$ & $<1.61 \mathrm{E}+00$ & $<1.54 \mathrm{E}+00$ & $<1.62 \mathrm{E}+00$ & $<1.79 \mathrm{E}+00$ & $<1.87 \mathrm{E}+00$ & $<8.06 \mathrm{E}-01$ & $<8.05 \mathrm{E}-01$ & $<7.12 \mathrm{E}-01$ & $<7.16 \mathrm{E}-01$ & $<6.62 \mathrm{E}-01$ & $<6.91 \mathrm{E}-01$ \\
\hline 133 & $1.43 \mathrm{E}+00$ & $1.54 \mathrm{E}+00$ & $<9.52 \mathrm{E}-02$ & $1.48 \mathrm{E}+00$ & $1.55 \mathrm{E}+00$ & $1.50 \mathrm{E}+00$ & $1.55 \mathrm{E}+00$ & $<9.52 \mathrm{E}-02$ & $1.62 \mathrm{E}+00$ & $1.55 \mathrm{E}+00$ & $1.54 \mathrm{E}+00$ & $1.38 \mathrm{E}+00$ & $1.55 \mathrm{E}+00$ & $1.67 \mathrm{E}+00$ \\
\hline 134 & $<5.05 \mathrm{E}-01$ & $<5.16 \mathrm{E}-01$ & $<6.35 \mathrm{E}-01$ & $<5.45 \mathrm{E}-01$ & $<5.22 \mathrm{E}-01$ & $<5.48 \mathrm{E}-01$ & $<6.06 \mathrm{E}-01$ & $<6.35 \mathrm{E}-01$ & $<3.23 \mathrm{E}-02$ & $<3.22 \mathrm{E}-02$ & $<2.85 \mathrm{E}-02$ & $<2.87 \mathrm{E}-02$ & $2.65 \mathrm{E}-02$ & $2.77 \mathrm{E}-02$ \\
\hline 135 & $1.98 \mathrm{E}-01$ & $2.83 \mathrm{E}-01$ & $<6.35 \mathrm{E}-02$ & $2.30 \mathrm{E}-01$ & $1.83 \mathrm{E}-01$ & $1.79 \mathrm{E}-01$ & $2.08 \mathrm{E}-01$ & $<6.35 \mathrm{E}-02$ & $1.91 \mathrm{E}-01$ & $1.86 \mathrm{E}-01$ & $1.87 \mathrm{E}-01$ & & & $2.10 \mathrm{E}-01$ \\
\hline 136 & $<5.56 \mathrm{E}-01$ & $<5.67 \mathrm{E}-01$ & $<6.98 \mathrm{E}-01$ & $<6.00 \mathrm{E}-01$ & $<5.74 \mathrm{E}-01$ & $<6.02 \mathrm{E}-01$ & $<6.67 \mathrm{E}-01$ & $<6.98 \mathrm{E}-01$ & $<2.26 \mathrm{E}-01$ & $<2.25 \mathrm{E}-01$ & $<1.99 \mathrm{E}-01$ & $<2.01 \mathrm{E}-01$ & $<1.85 \mathrm{E}-01$ & $<1.94 \mathrm{E}-01$ \\
\hline 137 & 4.57E- 01 & $4.98 \mathrm{E}-01$ & $<9.52 \mathrm{E}-02$ & $5.08 \mathrm{E}-01$ & 4.54 & 5.281 & 4.15 & $1.28 \mathrm{E}-01$ & 4.24E-01 & 4.36 & 4.17 & & & $4.30 \mathrm{E}-01$ \\
\hline 138 & $4.71 \mathrm{E}-01$ & $7.18 \mathrm{E}-01$ & $<1.90 \mathrm{E}-01$ & 4.61E-01 & $2.71 \mathrm{E}-01$ & $3.66 \mathrm{E}-01$ & 3.86E-01 & $4.52 \mathrm{E}-01$ & $<5.38 \mathrm{E}-02$ & $<5.37 \mathrm{E}-02$ & $<4.75 \mathrm{E}-02$ & & $<4.41$ & $<4.61 \mathrm{E}-02$ \\
\hline 139 & $<5.05 \mathrm{E}-02$ & $<5.16 \mathrm{E}-02$ & $<6.35 \mathrm{E}-02$ & $<5.45 \mathrm{E}-02$ & $<5.22 \mathrm{E}-02$ & $<5.48 \mathrm{E}-02$ & $<6.06 \mathrm{E}-02$ & $<6.35 \mathrm{E}-02$ & $<2.15 \mathrm{E}-02$ & $<2.15 \mathrm{E}-02$ & $<1.90 \mathrm{E}-02$ & $<1.91 \mathrm{E}-02$ & $<1.77$ & $<1.84 \mathrm{E}-02$ \\
\hline 140 & $<5.05 \mathrm{E}-02$ & $<5.16 \mathrm{E}-02$ & -02 & $<5.45$ & $<5.22 \mathrm{E}-02$ & $<5.481$ & $<6.06 \mathrm{E}-02$ & $<6.35 \mathrm{E}-02$ & 02 & $<2.15$ & $<1.9$ & $<1$. & $<1$. & $<1.84 \mathrm{E}-02$ \\
\hline 141 & $<5.05 \mathrm{E}-02$ & $<5.16 \mathrm{E}-02$ & $<6.35 \mathrm{E}-02$ & $<5.45 \mathrm{E}-02$ & $<5.2$ & $<5.48 \mathrm{E}-02$ & $<6.06 \mathrm{E}-02$ & E-02 & $<2.15 \mathrm{E}-02$ & $<2.1$ & $<1$ & $<1$. & & $\mathrm{E}-02$ \\
\hline 142 & $<5.05 \mathrm{E}-02$ & $<5.16 \mathrm{E}-02$ & $<6.35 \mathrm{E}-02$ & $<5.45 \mathrm{E}-02$ & $<5.22 \mathrm{E}-02$ & $<5.48 \mathrm{E}-02$ & $<6.06 \mathrm{E}-02$ & $<6.35 \mathrm{E}-02$ & $<2.15 \mathrm{E}-02$ & $<2.15 \mathrm{E}-02$ & $<1.90$ & $<1.91$ & $<1.77$ & $<1.84 \mathrm{E}-02$ \\
\hline 143 & $<5.05 \mathrm{E}-02$ & $<5.16 \mathrm{E}-02$ & & $<5.4$ & $<5$. & $<5.48 \mathrm{E}-02$ & $<6.06 \mathrm{E}-02$ & $<6.35 \mathrm{E}-02$ & $<2.15 \mathrm{E}-02$ & $<2.1$ & $<1.9$ & $<1.9$ & $<1$. & $<1.84 \mathrm{E}-02$ \\
\hline 144 & $<5.05 \mathrm{E}-02$ & $<5.16 \mathrm{E}-02$ & $<6.35 \mathrm{E}-02$ & $<5.45 \mathrm{E}-02$ & $<5.22 \mathrm{E}-02$ & $<5.48 \mathrm{E}-02$ & $<6.06 \mathrm{E}-02$ & $<6.35 \mathrm{E}-02$ & $<2.15 \mathrm{E}-02$ & $<2.1$ & $<1.9$ & $<1.9$ & $<1$. & $<1.84 \mathrm{E}-02$ \\
\hline 145 & $<5.05 \mathrm{E}-02$ & $<5.16 \mathrm{E}-02$ & $<6.35 \mathrm{E}-02$ & $<5.4$ & $<5.2$ & $<5.4$ & $<6.0$ & -02 & $<2.1$ & $<2$. & $<1$. & $<1$ & & E-02 \\
\hline 146 & $<5.05 \mathrm{E}$ & $<5.16 \mathrm{E}-02$ & & $<5.4$ & $<5.2$ & $<5$. & $<6$. & & & $<2$. & & & & \\
\hline 147 & $<5.05 \mathrm{E}-02$ & $<5.16 \mathrm{E}-02$ & $<6.35 \mathrm{E}-02$ & $<5.45 \mathrm{E}-02$ & $<5.22$ & $<5.48 \mathrm{E}-02$ & $<6.06 \mathrm{E}-02$ & $<6.35 \mathrm{E}-02$ & $<2.1$ & $<2.1$ & $<1.9$ & $<1.9$ & 02 & $<1.84 \mathrm{E}-02$ \\
\hline 148 & $<5.05 \mathrm{E}-02$ & $<5.16 \mathrm{E}-02$ & -02 & $<5.4$ & $<5$ & $<5$. & $<6$. & -02 & $<2$. & $<2$ & $<1$ & $<1$ & & E-02 \\
\hline 149 & $<5.05 \mathrm{E}-02$ & $<5.16 \mathrm{E}-02$ & -02 & $<5.4$ & $<5.2$ & $<5.4$ & $<6.06 \mathrm{E}-02$ & $<6.35 \mathrm{E}-02$ & $<2$. & $<2$. & $<1.9$ & $<1.9$ & $<1$. & $<1.84 \mathrm{E}-02$ \\
\hline 150 & $<5.05 \mathrm{E}-02$ & $<5.16 \mathrm{E}-02$ & $<6.35 \mathrm{E}-02$ & $<54$ & $<5.2$ & $<5.481$ & $<606$ & $<63$ & $<2$ & & & & & $<1.84 \mathrm{E}-02$ \\
\hline 151 & $<5.05 \mathrm{E}-02$ & $<5.16 \mathrm{E}-02$ & -02 & $<5.4$ & $<5$ & $<5.4$ & $<6$ & -02 & $<2$ & $<2$ & $<1$ & $<1$ & $<1$ & $\mathrm{E}-02$ \\
\hline 152 & $<5.05 \mathrm{E}-02$ & $<5.16 \mathrm{E}-02$ & $\mathrm{E}-02$ & $<5.4$ & $<5$ & $<5.48$ & $<6$. & 8-02 & $<2$ & $<2$ & $<1$ & $<1$ & 02 & $<1.84 \mathrm{E}-02$ \\
\hline 153 & $<5.05 \mathrm{E}-02$ & $<5.16 \mathrm{E}-02$ & & $<5$. & $<5$. & & $<6$ & & & & & & & $<1.8$ \\
\hline 154 & $<5.05 \mathrm{E}-02$ & $<5.16 \mathrm{E}-02$ & -02 & $<5.4$ & $<5$. & $<5$. & $<6$. & -02 & $<2$. & $<2$ & $<1$ & $<1$. & $<1$ & $<1.84 \mathrm{E}-02$ \\
\hline 155 & $<5.05 \mathrm{E}-02$ & $<5.16 \mathrm{E}-02$ & $35 \mathrm{E}-02$ & $<5.45 \mathrm{E}-02$ & $<5.22 \mathrm{E}-02$ & $<5.48 \mathrm{E}-02$ & $<6.06 \mathrm{E}-02$ & $<6.35 \mathrm{E}-02$ & $<2.15 \mathrm{E}-02$ & $<2$. & $<1$ & $<1.9$ & $<1$. & $<1.84 \mathrm{E}-02$ \\
\hline 156 & & & & & & & & & & & & & & \\
\hline 157 & $<5.05 \mathrm{E}-02$ & $<5.16 \mathrm{E}-02$ & -02 & $<5.4$ & $<5.2$ & $<5.48$ & $<6.06$ & -02 & $<2$. & $<2$ & & $<1$. & $<1$. & $\mathrm{E}-02$ \\
\hline 158 & $<5.05 \mathrm{E}-02$ & $<5.16 \mathrm{E}-02$ & $<6.35 \mathrm{E}-02$ & $<5.45$ & $<5.22 \mathrm{E}-02$ & $<5.48 \mathrm{E}-02$ & $<6.06 \mathrm{E}-02$ & $<6.35 \mathrm{E}-02$ & $<2.15 \mathrm{E}-02$ & $<2.1$ & $<1$. & $<1.91$ & $<1.77$ & $<1.84 \mathrm{E}-02$ \\
\hline 15 & & & & & & & & & & & & & & \\
\hline 160 & $<5.05 \mathrm{E}-02$ & $<5.16 \mathrm{E}-02$ & -02 & $<5.4$ & $<5$ & $<5$. & $<6$ & 02 & $<2$. & $<2$ & $<1$ & $<1$ & $<1$ & $<1.84 \mathrm{E}-02$ \\
\hline 161 & & $<5.16 \mathrm{E}-02$ & -02 & $<5$ & $<5$. & & & $35 \mathrm{E}-02$ & 02 & $<2$. & $<1$ & $<1$. & $<1$ & $<1.84 \mathrm{E}-02$ \\
\hline 10 & & & & & & & & & & & & & & \\
\hline 163 & $<5.05 \mathrm{E}-02$ & $<5.16 \mathrm{E}-02$ & $\mathrm{E}-02$ & $<5.45$ & $<5.2$ & $<5.48 \mathrm{E}-02$ & $<6$ & $5 \mathrm{E}-02$ & -02 & $<2.1$ & $<1$ & $<1$. & $<1$. & $<1.84 \mathrm{E}-02$ \\
\hline 164 & $<5.05 \mathrm{E}-02$ & $<5.16 \mathrm{E}-02$ & $<6.35 \mathrm{E}-02$ & $<5.45 \mathrm{E}-02$ & $<5.22 \mathrm{E}-02$ & $<5.48 \mathrm{E}-02$ & $<6.06 \mathrm{E}-02$ & $<6.35 \mathrm{E}-02$ & $<2.1$ & $<2.1$ & $<1$. & $<1.9$ & $<1.7$ & $<1.84 \mathrm{E}-02$ \\
\hline 16 & & & & & & & & & & & & & & \\
\hline 16 & $<5.05 \mathrm{E}-02$ & $<5.16 \mathrm{E}-02$ & $\mathrm{E}-02$ & $<5$ & $<5.22 \mathrm{E}-02$ & $<5.48 \mathrm{E}-02$ & $<6.06 \mathrm{E}-02$ & $35 \mathrm{E}-02$ & $5 \mathrm{E}-02$ & $<2.15$ & $<1.90 \mathrm{E}-02$ & 02 & $<1.77$ & $<1.84 \mathrm{E}-02$ \\
\hline 167 & $<5.051$ & $<5.16 \mathrm{E}-02$ & & $<5.4$ & $<5.2$ & & & & & & & & & $<1.84 \mathrm{E}-02$ \\
\hline 16 & & & & & & & & & & & & & & \\
\hline 169 & $<5.05 \mathrm{E}-02$ & $<5.16 \mathrm{E}-02$ & $<6.35 \mathrm{E}-02$ & $<5.45 \mathrm{E}-02$ & $<5.22 \mathrm{E}-02$ & $<5.48 \mathrm{E}-02$ & $<6.06 \mathrm{E}-02$ & $<6.35 \mathrm{E}-02$ & $<3.23 \mathrm{E}-02$ & $<3.22 \mathrm{E}-02$ & $<2.85 \mathrm{E}-02$ & $<2.87 \mathrm{E}-02$ & $<2.65 \mathrm{E}-02$ & $<2.77 \mathrm{E}-02$ \\
\hline 170 & $<5.05 \mathrm{E}-02$ & $<5.16 \mathrm{E}-02$ & $<6.35 \mathrm{E}-02$ & $<5.45 \mathrm{E}-02$ & $<5.22$ & & & & -02 & & & & & \\
\hline 17 & $<5.05 \mathrm{E}-02$ & $<5.16 \mathrm{E}-02$ & $<6$. & $<5.4$ & $<5$ & $<5$ & $<6$ & $<6$ & $<2$. & $<2$. & & & $<1.77 \mathrm{E}-02$ & $<1.84 \mathrm{E}-02$ \\
\hline 172 & $<5.05 \mathrm{E}-02$ & $<5.16 \mathrm{E}-02$ & $<6.35 \mathrm{E}-02$ & $<5.45 \mathrm{E}-02$ & $<5.22 \mathrm{E}-02$ & $<5.48 \mathrm{E}-02$ & $<6.06 \mathrm{E}-02$ & $<6.35 \mathrm{E}-02$ & $<2.15 \mathrm{E}-02$ & $<2.15 \mathrm{E}-02$ & $<1.90 \mathrm{E}-02$ & $<1.91 \mathrm{E}-02$ & $<1.77 \mathrm{E}-02$ & $<1$ \\
\hline
\end{tabular}


Table A-2. ICP-MS of acid dilutions of sludge contact tests (mg/L), nominal uncertainty $=\mathbf{2 0} \%$ (contd.)

\begin{tabular}{|c|c|c|c|c|c|c|c|c|c|c|c|c|c|c|c|c|}
\hline hold & 14 & 14 & Standard 1 & 14 & 14 & 14 & 14 & andard 2 & 14 & 14 & 21 & 21 & 21 & 21 & 21 & 21 \\
\hline$(\mathrm{g} / \mathrm{L})$ & 0 & 0 & 0 & 5 & 5 & 10 & 10 & 10 & 0.2 & 0.2 & 0 & 0 & 5 & - & 10 & 10 \\
\hline $\mathrm{F}(\mathrm{mL} / \mathrm{mL})$ & 10.44 & 10.89 & 12.70 & 9.77 & 9.80 & 9.31 & 10.10 & 12.70 & 11.77 & 10.41 & 11.26 & 10.68 & 9.35 & 10.07 & 11.21 & 11.60 \\
\hline LIMS numbers & 300303331 & 300303332 & 300303333 & 300303334 & 300303335 & 300303336 & 300303337 & 300303338 & 300303339 & 300303340 & 300303355 & 300303356 & 300303357 & 300303358 & 300303359 & 00303360 \\
\hline $\mathrm{m} / \mathrm{z})=126$ & $<8.35 \mathrm{E}-02$ & $<8.71 \mathrm{E}-02$ & $<1.02 \mathrm{E}-01$ & $<7.81 \mathrm{E}-02$ & $<7.84 \mathrm{E}-02$ & $<7.45 \mathrm{E}-02$ & $<8.08 \mathrm{E}-02$ & $<1.02 \mathrm{E}-01$ & $<9.42 \mathrm{E}-02$ & $<8.33 \mathrm{E}-02$ & $<6.76 \mathrm{E}-02$ & $<6.41 \mathrm{E}-02$ & $<5.61 \mathrm{E}-02$ & $<6.04 \mathrm{E}-02$ & $<6.72 \mathrm{E}-02$ & $<6.96 \mathrm{E}-02$ \\
\hline 128 & $<2.50 \mathrm{E}-01$ & $<2.61 \mathrm{E}-01$ & $<3.05 \mathrm{E}-01$ & $<2.34 \mathrm{E}-01$ & $<2.35 \mathrm{E}-01$ & $<2.24 \mathrm{E}-01$ & $<2.43 \mathrm{E}-01$ & $<3.05 \mathrm{E}-01$ & $<2.82 \mathrm{E}-01$ & $<2.50 \mathrm{E}-01$ & $<3.60 \mathrm{E}-01$ & $<3.42 \mathrm{E}-01$ & $<2.99 \mathrm{E}-01$ & $<3.22 \mathrm{E}-01$ & $<3.59 \mathrm{E}-01$ & $<3.71 \mathrm{E}-01$ \\
\hline 130 & $<4.49 \mathrm{E}-01$ & $<4.68 \mathrm{E}-01$ & $<5.46 \mathrm{E}-01$ & $<4.20 \mathrm{E}-01$ & $<4.22 \mathrm{E}-01$ & $<4.01 \mathrm{E}-01$ & $<4.34 \mathrm{E}-01$ & $\mathrm{E}-01$ & & & & $1 \mathrm{E}-01$ & & & & \\
\hline 133 & $1.51 \mathrm{E}+00$ & $1.53 \mathrm{E}+00$ & $<2.54 \mathrm{E}-02$ & $1.43 \mathrm{E}+00$ & $1.44 \mathrm{E}+00$ & $1.56 \mathrm{E}+00$ & $1.53 \mathrm{E}+00$ & $<2.54 \mathrm{E}-02$ & $1.44 \mathrm{E}+00$ & $1.52 \mathrm{E}+00$ & $1.49 \mathrm{E}+00$ & $1.49 \mathrm{E}+00$ & $1.49 \mathrm{E}+00$ & $1.52 \mathrm{E}+00$ & $1.62 \mathrm{E}+00$ & $1.55 \mathrm{E}+00$ \\
\hline 134 & $<3.34 \mathrm{E}-01$ & $<3.48 \mathrm{E}-01$ & $<4.06 \mathrm{E}-01$ & $<3.13 \mathrm{E}-01$ & $<3.14 \mathrm{E}-01$ & $<2.98 \mathrm{E}-01$ & $<3.23 \mathrm{E}-01$ & $<4.06 \mathrm{E}-01$ & $<3.77 \mathrm{E}-01$ & $<3.33 \mathrm{E}-01$ & $<2.93 \mathrm{E}-01$ & $<2.78 \mathrm{E}-01$ & $<2.43 \mathrm{E}-01$ & $<2.62 \mathrm{E}-01$ & $<2.91 \mathrm{E}-01$ & $<3.02 \mathrm{E}-01$ \\
\hline 135 & $1.87 \mathrm{E}-01$ & 2.03E- 01 & $<2.54 \mathrm{E}-02$ & $1.74 \mathrm{E}-01$ & $1.88 \mathrm{E}-01$ & $1.85 \mathrm{E}-01$ & $1.86 \mathrm{E}-01$ & $<2.54 \mathrm{E}-02$ & & $2.00 \mathrm{E}-01$ & & $2.05 \mathrm{E}-01$ & & & & $2.25 \mathrm{E}-01$ \\
\hline 136 & $<5.22 \mathrm{E}-02$ & $<5.44 \mathrm{E}-02$ & $<6.35 \mathrm{E}-02$ & $<4.88 \mathrm{E}-02$ & $<4.90 \mathrm{E}-02$ & $<4.66 \mathrm{E}-02$ & $<5.05 \mathrm{E}-02$ & $<6.35 \mathrm{E}-02$ & $<5.88 \mathrm{E}-02$ & $<5.21 \mathrm{E}-02$ & $<2.36 \mathrm{E}-01$ & $<2.24 \mathrm{E}-01$ & $<1.96 \mathrm{E}-01$ & $<2.11 \mathrm{E}-01$ & $<2.35 \mathrm{E}-01$ & $<2.44 \mathrm{E}-01$ \\
\hline 137 & 4.41E-01 & 4.41E- 01 & $<2.54 \mathrm{E}-02$ & $4.58 \mathrm{E}-01$ & $4.71 \mathrm{I}$ & 4.49E-01 & 4.29E- 01 & $<2.54 \mathrm{E}-02$ & $4.38 \mathrm{E}-01$ & $4.48 \mathrm{E}-01$ & 4.58 & 4.66E- 01 & $4.27 \mathrm{E}-01$ & $4.60 \mathrm{E}-01$ & & 4.64E- 01 \\
\hline 138 & $=8.35 \mathrm{E}-02$ & $<8.71 \mathrm{E}-02$ & $1.12 \mathrm{E}-01$ & $<7.81 \mathrm{E}-02$ & $<7.84 \mathrm{E}-02$ & $<7.45 \mathrm{E}-02$ & $<8.08 \mathrm{E}-02$ & $1.19 \mathrm{E}-01$ & $<9.42 \mathrm{E}-02$ & $<8.33 \mathrm{E}-02$ & $<3.38 \mathrm{E}-02$ & $<3.21 \mathrm{E}-02$ & $<2.81 \mathrm{E}-02$ & $<3.02 \mathrm{E}-02$ & & $<3.48 \mathrm{E}-02$ \\
\hline 139 & $<2.09 \mathrm{E}-02$ & $<2.18 \mathrm{E}-02$ & $<2.54 \mathrm{E}-02$ & $<1.95 \mathrm{E}-02$ & $<1.96 \mathrm{E}-02$ & $<1.86 \mathrm{E}-02$ & $<2.02$ E- 02 & $<2.54 \mathrm{E}-02$ & $<2.35 \mathrm{E}-02$ & $<2.08 \mathrm{E}-02$ & $<2.2$ & $<2.14 \mathrm{E}-02$ & $<1.87 \mathrm{E}-02$ & $<2.01 \mathrm{E}-02$ & $<2.24 \mathrm{E}-02$ & $<2.32 \mathrm{E}-02$ \\
\hline 140 & $<2.09 \mathrm{E}-02$ & $<2.18 \mathrm{E}-02$ & $<2.54 \mathrm{E}-02$ & $<1.95$ & $<1.96$ & 5186 & $<2.02 \mathrm{E}-02$ & & & & & & & & & \\
\hline 141 & $<2.09 \mathrm{E}-02$ & $<2.18$ & $<2.54 \mathrm{E}-02$ & $<1.95$ & $<1.96$ & $<1.86$ & $<2.02 \mathrm{E}-02$ & 02 & $<2.3$ & $<2.08 \mathrm{E}-02$ & 02 & $<2$ & $<1$. & $<2.0$ & $<2$ & $<2.32 \mathrm{E}-02$ \\
\hline 142 & $<2.09 \mathrm{E}-02$ & $<2.18 \mathrm{E}-02$ & $<2.54 \mathrm{E}-02$ & $<1.95$ & $<1.96 \mathrm{I}$ & $<1.86 \mathrm{E}-02$ & $<2.02 \mathrm{E}-02$ & E-02 & $<2$ & $<2.08 \mathrm{E}-02$ & $<2$. & $<2$ & $<1$. & $<2.0$ & $<2$ & E- 02 \\
\hline 143 & $<2.0$ & $<2$. & & $<1$ & $<1$. & & $<2.02 \mathrm{E}-02$ & & & & & & & & & \\
\hline 144 & $<2.09 \mathrm{E}-02$ & $<2.18 \mathrm{E}-02$ & $<2.54 \mathrm{E}-02$ & $<1.95$ & $<1.96 \mathrm{E}-02$ & $<1.86 \mathrm{E}-02$ & $<2.02 \mathrm{E}-02$ & $<2.54 \mathrm{E}-02$ & $<2.35$ & $<2.08 \mathrm{E}-02$ & $<2$. & $<2$ & $<1$ & $<2.0$ & $<2$ & $<2.32 \mathrm{E}-02$ \\
\hline 145 & $<2.09 \mathrm{E}-02$ & $<2.1$ & $<2.54 \mathrm{E}-02$ & $<1.95$ & $<1.9$ & $<1.86$ & $<2.02 \mathrm{E}-02$ & & $<2$ & $<2$ & $<2$. & & & $<2$ & & \\
\hline 146 & $2.09 \mathrm{E}-02$ & $<2.1$ & $<2.5$ & $<1.95$ & & $<18$ & $<200$ & & & $<2$ & & & & & & \\
\hline 147 & $<2.09 \mathrm{E}-02$ & $<2.18 \mathrm{E}-02$ & $<2.54 \mathrm{E}-02$ & $<1.95$ & $<1.96$ & $<1.86 \mathrm{I}$ & $<2.02 \mathrm{E}-02$ & $\mathrm{E}-02$ & $<2$ & $<2$ & $<2$. & & & $<2.01$ & $<2$ & $<2.32 \mathrm{E}-02$ \\
\hline 148 & $<2.09 \mathrm{E}-02$ & $<2.18 \mathrm{E}-02$ & $<2.54 \mathrm{E}-02$ & $<1.951$ & $<1.96$ & $<1.861$ & $<2.02 \mathrm{E}-02$ & $\mathrm{E}-02$ & $<2.3$ & $<2.08 \mathrm{E}-02$ & $<2$. & $<2$ & -02 & $<2$. & $<2$ & \\
\hline 149 & $<2.09 \mathrm{E}-02$ & $<2.18 \mathrm{E}-02$ & $<2.54 \mathrm{E}-02$ & $<1.95 \mathrm{E}-02$ & $<1.96 \mathrm{E}-02$ & $<1.86 \mathrm{E}-02$ & $<2.02 \mathrm{E}-02$ & 02 & $<2.35$ & $<2.08$ & $<2$. & $<2$ & $<1$ & $<2$ & $<2.2$ & $<2$ \\
\hline 150 & $<2.09 \mathrm{E}-02$ & $<2.18 \mathrm{E}-02$ & $<2.54 \mathrm{E}-02$ & $<1.95$ & $<1.96$ & $<1.86$ & $<2.02 \mathrm{E}-02$ & $<2$ & $<2$. & $<2$ & $<2$ & & $<1$. & $<2$ & & E- 02 \\
\hline 151 & $<2.09 \mathrm{E}-02$ & $<2.18$ & $<2.54$ & $<1.95$ & $<1.96$ & $<1.86$ & $<2.02 \mathrm{E}-02$ & -02 & $<2.35$ & $<2.08 \mathrm{E}-02$ & 02 & $<2.1$ & -02 & $<2.01$ & $<2.2$ & $<2.32 \mathrm{E}-02$ \\
\hline 152 & 2.05 & $<2$ & $<2.54$ & $<1.9$ & $<1$. & & $<2$ & & & & & & & & & $<2.32 \mathrm{E}-02$ \\
\hline 153 & $<2.09 \mathrm{E}-02$ & $<2.18 \mathrm{E}-02$ & $<2.54 \mathrm{E}-02$ & $<1.95 \mathrm{E}-02$ & $<1.96 \mathrm{E}-02$ & $<1.86 \mathrm{E}-02$ & $<2.02 \mathrm{E}-02$ & $\mathrm{E}-02$ & $<2.3$ & $<2.08 \mathrm{E}-02$ & $<2$ & $<2$ & $<1$. & $<2$ & $<2$. & $<2.32 \mathrm{E}-02$ \\
\hline 154 & $2.09 \mathrm{E}-02$ & $<2.18 \mathrm{E}-02$ & $<2.54 \mathrm{E}-02$ & $<1.95 \mathrm{E}-02$ & $<1.9$ & & $<2.02 \mathrm{E}-02$ & & $<2.35$ & $<2.08 \mathrm{E}-02$ & 02 & $<2.1$ & $<1.8$ & $<2$ & $<2$ & $<2.32 \mathrm{E}-02$ \\
\hline 155 & $<2.09 \mathrm{E}-02$ & $<2.1$ & $<2.54$ & $<$ & $<1$ & $<1$ & & & & & & & & & & $<2$ \\
\hline 156 & $2.09 \mathrm{E}-02$ & $<2.1$ & $<2.54$ & $<1.95$ & $<1$. & $<1$. & $<2$ & & $<$ & $<2$ & & & & & $<2$ & 8-02 \\
\hline 157 & $2.09 \mathrm{E}-02$ & $<2$. & & & $<1$ & & & & & & & & & & & \\
\hline 158 & $<2.09$ & $<2$ & $<2.5$ & $<1.95$ & $<1$. & & & & & & & & & & & \\
\hline 159 & $<2.09 \mathrm{E}-02$ & $<2.18 \mathrm{E}-02$ & $<2.54 \mathrm{E}-02$ & $<1.95 \mathrm{E}-02$ & $<1.96 \mathrm{E}-02$ & $<1.86 \mathrm{E}-02$ & $<2.02 \mathrm{E}-02$ & -02 & $<2$. & $<2.0$ & 02 & $<2$. & 02 & $<2$ & $<2.2$ & $<2.32 \mathrm{E}-02$ \\
\hline 160 & & & & & & & & & & & & & & & & \\
\hline 161 & $<2.09 \mathrm{E}-02$ & $<2$. & $54 \mathrm{E}-02$ & 22 & $<$ & 02 & -02 & 02 & $<$ & $<2$ & & $<2$ & $<1$ & $<2$ & $<2$ & 8-02 \\
\hline 162 & $2.09 \mathrm{E}-02$ & $<2.18$ & $<2.54$ & $<1.95$ & $<1.96$ & $<1.86$ & & & & $<2$ & & & & & $<2$ & $<2.32 \mathrm{E}-02$ \\
\hline 163 & & & & & & & & & & & & & & & & \\
\hline 164 & $<2.09 \mathrm{E}-02$ & $<2.18 \mathrm{E}-02$ & $<2.54 \mathrm{E}-02$ & $<1.95 \mathrm{E}-02$ & $<1.96 \mathrm{E}-02$ & $<1.86 \mathrm{E}-02$ & $<2.02 \mathrm{E}-02$ & $<2.54 \mathrm{E}-02$ & $<2.35$ & $<2.08 \mathrm{E}-02$ & $<2.25 \mathrm{E}-02$ & $<2.1$ & $<1.87 \mathrm{E}-02$ & $<2.01 \mathrm{E}-02$ & $<2.24 \mathrm{E}-02$ & $<2.32 \mathrm{E}-02$ \\
\hline 165 & $<2.09 \mathrm{E}-02$ & & & & & & & & & & & & & & & \\
\hline 166 & $<2.09 \mathrm{E}-02$ & $<2$. & $<2.54$ & & & & & & & & & & & & & E- 02 \\
\hline 167 & $<2.09 \mathrm{E}-02$ & $<2.18 \mathrm{E}-02$ & $<2.54 \mathrm{E}-02$ & $<1.95 \mathrm{E}-02$ & $<1.96 \mathrm{E}-02$ & $<1.86 \mathrm{E}-02$ & $<2.02$ E- 02 & $8-02$ & $<2.35 \mathrm{E}-02$ & $<2.08 \mathrm{E}-02$ & -02 & $<2$ & $\mathrm{E}-02$ & $<2.01 \mathrm{E}-02$ & $<2.24 \mathrm{E}-02$ & $<2.32 \mathrm{E}-02$ \\
\hline 168 & $<2.09 \mathrm{E}-02$ & $<2$ & & & & & & & & & & & & & & \\
\hline 169 & $<2.09 \mathrm{E}-02$ & $<2.18 \mathrm{E}-02$ & $<2.54 \mathrm{E}-02$ & $<1.95 \mathrm{E}-02$ & $<1.96 \mathrm{E}-02$ & $<1.86 \mathrm{E}-02$ & $<2.02 \mathrm{E}-02$ & $<2.54 \mathrm{E}-02$ & $<2.35 \mathrm{E}-02$ & $<2.08 \mathrm{E}-02$ & $<2.25 \mathrm{E}-02$ & $<2.14 \mathrm{E}-02$ & $<1.87 \mathrm{E}-02$ & $<2.01 \mathrm{E}-02$ & $<2.24 \mathrm{E}-02$ & $<2.32 \mathrm{E}-02$ \\
\hline 170 & $<2.09 \mathrm{E}-02$ & $<2.18 \mathrm{E}-02$ & $<2.54$ & & & & & & & & & & & & & \\
\hline 1 & $<2.09 \mathrm{E}-02$ & $<2$. & $<2$ & $<1$ & & & & & & & & & & & & $<2.32 \mathrm{E}-02$ \\
\hline 172 & $<2.09 \mathrm{E}-02$ & $<2.18 \mathrm{E}-02$ & $<2.54 \mathrm{E}-02$ & $<1.95 \mathrm{E}-02$ & $<1.96 \mathrm{E}-02$ & $<1.86 \mathrm{E}-02$ & $<2.02 \mathrm{E}-02$ & $<2.54 \mathrm{E}-02$ & $<2.35 \mathrm{E}-02$ & $<2.08 \mathrm{E}-02$ & $<2.25 \mathrm{E}-02$ & $<2.14 \mathrm{E}-02$ & $<1.87 \mathrm{E}-02$ & $<2.01 \mathrm{E}-02$ & $<2.24 \mathrm{E}-02$ & $<2.32 \mathrm{E}-02$ \\
\hline
\end{tabular}


Table A-2. ICP-MS of acid dilutions of sludge contact tests $(\mathrm{mg} / \mathrm{L}$ ), nominal uncertainty $=\mathbf{2 0} \%$ (contd.)

\begin{tabular}{|c|c|c|c|c|c|c|c|c|c|c|c|c|c|c|c|c|}
\hline iys) & 35 & 35 & andard 1 & 35 & 35 & 35 & 35 & andard 2 & 35 & 35 & 35 & 35 & 35 & 35 & 35 & 35 \\
\hline$e(g / L)$ & 0 & 0 & 0 & 5 & 5 & 10 & 10 & 10 & 0.2 & 0.2 & 0 & 0 & 5 & 5 & 10 & 10 \\
\hline$(\mathrm{mL} / \mathrm{mL})$ & 10.74 & 9.26 & 12.70 & 11.78 & 10.95 & 12.04 & 10.23 & 12.70 & 9.45 & 12.27 & 10.65 & 10.91 & 11.65 & 10.58 & 10.65 & 12.28 \\
\hline LIMS numbers & 300303385 & 300303386 & 300303387 & 300303388 & 300303389 & 300303390 & 300303391 & 300303392 & 300303393 & 300303394 & 300303395 & 300303396 & 300303397 & 300303398 & 300303399 & 300303400 \\
\hline $\mathrm{w} / \mathrm{z})=126$ & $<9.67 \mathrm{E}-02$ & $<8.34 \mathrm{E}-02$ & $<<1.14 \mathrm{E}-01$ & $<1.06 \mathrm{E}-01$ & $<9.86 \mathrm{E}-02$ & $<1.08 \mathrm{E}-01$ & $<9.21 \mathrm{E}-02$ & $<1.14 \mathrm{E}-01$ & $<8.51 \mathrm{E}-02$ & $<1.10 \mathrm{E}-01$ & $4.62 \mathrm{E}-02$ & $6.20 \mathrm{E}-02$ & $<4.66 \mathrm{E}-02$ & $<4.23 \mathrm{E}-02$ & $6.17 \mathrm{E}-02$ & $<4.91 \mathrm{E}-02$ \\
\hline 128 & $<2.15 \mathrm{E}-01$ & $<1.85 \mathrm{E}-01$ & $<2.54 \mathrm{E}-01$ & $<2.36 \mathrm{E}-01$ & $<2.19 \mathrm{E}-01$ & $<2.41 \mathrm{E}-01$ & $<2.05 \mathrm{E}-01$ & $<2.54 \mathrm{E}-01$ & $<1.89 \mathrm{E}-01$ & $<2.45 \mathrm{E}-01$ & $<1.70 \mathrm{E}-01$ & $<1.75 \mathrm{E}-01$ & $<1.86 \mathrm{E}-01$ & $<1.69 \mathrm{E}-01$ & $<1.70 \mathrm{E}-01$ & $<1.96 \mathrm{E}-01$ \\
\hline 130 & $<5.37 \mathrm{E}-01$ & $<4.63 \mathrm{E}-01$ & $6.35 \mathrm{E}-01$ & $<5.89 \mathrm{E}-01$ & $<5.48 \mathrm{E}-01$ & $<6.02 \mathrm{E}-01$ & & $<6.35 \mathrm{E}-01$ & $<4.73 \mathrm{E}-01$ & & $<5.75 \mathrm{E}-01$ & & & $<5.72 \mathrm{E}-01$ & & \\
\hline 133 & $1.48 \mathrm{E}+00$ & $1.51 \mathrm{E}+00$ & $<2.54 \mathrm{E}-02$ & $1.54 \mathrm{E}+00$ & $1.45 \mathrm{E}+00$ & $1.61 \mathrm{E}+00$ & $1.52 \mathrm{E}+00$ & $<2.54 \mathrm{E}-02$ & $1.52 \mathrm{E}+00$ & $1.46 \mathrm{E}+00$ & $1.53 \mathrm{E}+00$ & $1.59 \mathrm{E}+00$ & $1.53 \mathrm{E}+00$ & $1.50 \mathrm{E}+00$ & $1.59 \mathrm{E}+00$ & $1.51 \mathrm{E}+00$ \\
\hline 134 & $<1.61 \mathrm{E}-01$ & $<1.39 \mathrm{E}-01$ & $<1.90 \mathrm{E}-01$ & $<1.77 \mathrm{E}-01$ & $<1.64 \mathrm{E}-01$ & $<1.81 \mathrm{E}-01$ & $<1.53 \mathrm{E}-01$ & $<1.90 \mathrm{E}-01$ & $<1.42 \mathrm{E}-01$ & $<1.84 \mathrm{E}-01$ & $<3.51 \mathrm{E}-01$ & $<3.60 \mathrm{E}-01$ & $<3.85 \mathrm{E}-01$ & $<3.49 \mathrm{E}-01$ & $<3.51 \mathrm{E}-01$ & $4.05 \mathrm{E}-01$ \\
\hline 135 & $2.07 \mathrm{E}-01$ & $1.73 \mathrm{E}-01$ & $<2.54 \mathrm{E}-02$ & $2.22 \mathrm{E}-01$ & $1.91 \mathrm{E}-01$ & $1.69 \mathrm{E}-01$ & $1.86 \mathrm{E}-01$ & $<2.54 \mathrm{E}-02$ & $1.98 \mathrm{E}-01$ & $1.92 \mathrm{E}-01$ & $1.89 \mathrm{E}-01$ & $1.83 \mathrm{E}-01$ & & $2.09 \mathrm{E}-01$ & & $2.21 \mathrm{E}-01$ \\
\hline 136 & $<4.30 \mathrm{E}-02$ & $<3.70 \mathrm{E}-02$ & $<5.08 \mathrm{E}-02$ & $<4.71 \mathrm{E}-02$ & $<4.38 \mathrm{E}-02$ & $<4.82 \mathrm{E}-02$ & $<4.09 \mathrm{E}-02$ & $<5.08 \mathrm{E}-02$ & $<3.78 \mathrm{E}-02$ & $<4.91 \mathrm{E}-02$ & $<7.45 \mathrm{E}-02$ & $<7.64 \mathrm{E}-02$ & $<8.16 \mathrm{E}-02$ & $<7.41 \mathrm{E}-02$ & $<7.45 \mathrm{E}-02$ & $<8.59 \mathrm{E}-02$ \\
\hline 137 & 4.55E-01 & 4.61E-01 & $<2.54 \mathrm{E}-02$ & $5.26 \mathrm{E}-01$ & 4.47 & 4.55E-01 & 4.61E- 01 & $<2.54 \mathrm{E}-02$ & 4.61E- 01 & $4.89 \mathrm{E}-01$ & $4.98 \mathrm{E}-01$ & 4.73E-01 & 5.51 & 5.09 & & 4.53E- 01 \\
\hline 138 & $3.22 \mathrm{E}-02$ & $<2.78 \mathrm{E}-02$ & $1.54 \mathrm{E}-01$ & $<3.53 \mathrm{E}-02$ & $<3.29 \mathrm{E}-02$ & $<3.61 \mathrm{E}-02$ & $<3.07 \mathrm{E}-02$ & $1.03 \mathrm{E}-01$ & $<2.84 \mathrm{E}-02$ & $<3.68 \mathrm{E}-02$ & $<2.13 \mathrm{E}-02$ & $<2.18 \mathrm{E}-02$ & $<2.33 \mathrm{E}-02$ & $<2.12 \mathrm{E}-02$ & & $<2.46 \mathrm{E}-02$ \\
\hline 139 & $<2.15 \mathrm{E}-02$ & $<1.85 \mathrm{E}-02$ & $<2.54 \mathrm{E}-02$ & $<2.36 \mathrm{E}-02$ & $<2.19 \mathrm{E}-02$ & $<2.41 \mathrm{E}-02$ & $<2.05 \mathrm{E}-02$ & $<2.54 \mathrm{E}-02$ & $<1.89 \mathrm{E}-02$ & $<2.45 \mathrm{E}-02$ & $<2.13$ & $<2.18 \mathrm{E}-02$ & $<2.33 \mathrm{E}-02$ & $<2.12 \mathrm{E}-02$ & $<2.13 \mathrm{E}-02$ & $<2.46 \mathrm{E}-02$ \\
\hline 140 & $<2.15 \mathrm{E}-02$ & $<1.85 \mathrm{E}-02$ & $<254 \mathrm{E}-02$ & $<2.36 \mathrm{E}-02$ & $<2.1$ & $<2.41 \mathrm{E}-02$ & & & $<1.8$ & & 0 & & & & & \\
\hline 141 & $<2.15 \mathrm{E}-02$ & $<1.8$ & $<2.54 \mathrm{E}$ & $<2.36$ & $<2.1$ & $<2.4$ & $<2.05 \mathrm{E}-02$ & 02 & $<1.8$ & $<2$ & $<2.1$ & $<2.1$ & $<2.3$ & $<2$. & $<2.1$ & $<2.46 \mathrm{E}-02$ \\
\hline 142 & $<2.15 \mathrm{E}-02$ & $<1.85 \mathrm{E}-02$ & $<2.54 \mathrm{E}-02$ & $<2.3$ & $<2.1$ & $<2.41 \mathrm{E}-02$ & $<2.05 \mathrm{E}-02$ & -02 & $<1.8$ & $<2$ & $<2.1$ & $<2.1$ & $<2$ & & $<2$ & $<2.46 \mathrm{E}-02$ \\
\hline 143 & $<2.15 \mathrm{E}-02$ & $<1$. & $<2.5$ & & & & & & & & & & & & & \\
\hline 144 & $<2.15 \mathrm{E}-02$ & $<1.85 \mathrm{E}-02$ & $<2.54 \mathrm{E}-02$ & $<2.3$ & $<2$. & $<2.41 \mathrm{E}-02$ & $<2$. & $\mathrm{E}-02$ & $<1.89$ & $<2.45$ & $<2.1$ & $<2.1$ & $<2$ & $<2$ & $<2.1$ & $<2$ \\
\hline 145 & $<2.15 \mathrm{E}-02$ & $<1.8$ & $<2.5$ & $<2$. & $<2$. & $<2$ & & & $<1$. & & $<2$. & & & & & \\
\hline 146 & $<2.1$ & $<1.8$ & $<2.54$ & & & $<2$ & $<2$ & & & $<2$ & & & & & & \\
\hline 147 & $<2.15 \mathrm{E}-02$ & $<1.85 \mathrm{E}-02$ & $<2.54 \mathrm{E}-02$ & $<2$ & $<2$. & $<2.41 \mathrm{E}-02$ & & $\mathrm{E}-02$ & $<1.8$ & $<2$ & $<2.1$ & $<2$. & & & & $<2.46 \mathrm{E}-02$ \\
\hline 148 & $<2.15 \mathrm{E}-02$ & $<1.85 \mathrm{E}-02$ & $<2.54 \mathrm{E}-02$ & $<2$ & $<2$. & $<2.41 \mathrm{E}-02$ & $<2.05 \mathrm{E}-02$ & $\mathrm{E}-02$ & $<1.8$ & $<2.45 \mathrm{E}-02$ & $<2.1$ & $<2$ & & & & $<2.46 \mathrm{E}-02$ \\
\hline 149 & $<2.15 \mathrm{E}-02$ & $<1.85 \mathrm{E}-02$ & $<2.54 \mathrm{E}-02$ & $<2.3$ & $<2$. & $<2.41 \mathrm{E}-02$ & $<2.05 \mathrm{E}-02$ & $\mathrm{E}-02$ & $<1.8$ & $<2$ & $<2.1$ & $<2$ & & & $<2$. & $<2$ \\
\hline 150 & $<2.15 \mathrm{E}-02$ & $<1.8$ & $<2.54 \mathrm{E}-02$ & $<2.3$ & $<2$. & $<2$. & $<2$. & $<2$ & $<1$ & $<2$ & $<2$. & & & & & $<2$ \\
\hline 151 & $<2.15 \mathrm{E}-02$ & $<1.8$ & $<2.54$ & $<2.3$ & $<2.1$ & $<2.41 \mathrm{E}-02$ & $<2.0$ & -02 & $<1.8$ & $<2$ & 02 & $<2.18$ & $<2.3$ & $<2.1$ & $<2.1$ & $<2.46 \mathrm{E}-02$ \\
\hline 152 & $2.15 \mathrm{E}-02$ & $<1.85 \mathrm{E}-02$ & $<2.54 \mathrm{E}-02$ & $<2$ & & & & & & & & & & & & $<2.46 \mathrm{E}-02$ \\
\hline 153 & $<2.15 \mathrm{E}-02$ & $<1.85 \mathrm{E}-02$ & $<2.54 \mathrm{E}-02$ & $<2.3$ & $<2$. & $<2.41 \mathrm{E}-02$ & $<2.05 \mathrm{E}-02$ & $\mathrm{E}-02$ & $<1.89 \mathrm{E}-02$ & $<2$ & $<2$. & $<2$. & & & & $<2.46 \mathrm{E}-02$ \\
\hline 154 & $<2.15 \mathrm{E}-02$ & $<1.85 \mathrm{E}-02$ & $<2.54 \mathrm{E}-02$ & & $<2.1$ & & & & $<1.8$ & $<2.4$ & 02 & $<2.1$ & $<2.3$ & $<2.1$ & $<2$ & $<2.46 \mathrm{E}-02$ \\
\hline 155 & 2.15 & $<1.8$ & $<2.54$ & $<2$ & & & & & $<$ & & & & & & & 6E-02 \\
\hline 156 & $2.15 \mathrm{E}-02$ & $<1.8$ & $<2.54$ & $<2.3$ & $<2$ & $<2$ & $<2$ & 02 & $<$ & $<2$ & & & & & & $<2$ \\
\hline 157 & 2.1 & $<1$ & & & & & & & & & & & & & & \\
\hline 158 & $<2.1$ & $<1.8$ & $<2.5$ & $<2$. & $<2$ & & & & & & & & & & & $<2$ \\
\hline 159 & $<2.15 \mathrm{E}-02$ & $<1.85 \mathrm{E}-02$ & $<2.54 \mathrm{E}-02$ & $<2.36 \mathrm{E}-02$ & $<2.19 \mathrm{E}-02$ & $<2.41 \mathrm{E}-02$ & $<2.05 \mathrm{E}-02$ & -02 & $<1.89 \mathrm{E}-02$ & $<2$ & 02 & $<2$. & $<2.3$ & $<2$ & $<2$. & $<2.46 \mathrm{E}-02$ \\
\hline 160 & & & & & & & & & & & & & & & & \\
\hline 161 & $<2.15 \mathrm{E}-02$ & $<1$ & $54 \mathrm{E}-02$ & $<2$ & $<2$ & $<2$ & & 02 & 02 & $<2$ & $<$ & $<2$ & $<2$ & $<2$ & $<2$ & $<2.46 \mathrm{E}-02$ \\
\hline 162 & $<2.15 \mathrm{E}-02$ & $<1.85 \mathrm{E}-02$ & $<2.54$ & $<2$ & $<2$ & & & & $<1$. & $<2$. & & & & & & $<2.46 \mathrm{E}-02$ \\
\hline 163 & & & & & & & & & & & & & & & & \\
\hline 164 & $<2.15 \mathrm{E}-02$ & $<1.85 \mathrm{E}-02$ & $<2.54 \mathrm{E}-02$ & $<2.36 \mathrm{E}-02$ & $<2.19 \mathrm{E}-02$ & $<2.41 \mathrm{E}-02$ & $<2.05 \mathrm{E}-02$ & $<2.54 \mathrm{E}-02$ & $<1.89 \mathrm{E}-02$ & $<2.45 \mathrm{E}-02$ & $<2.1$ & $<2.18 \mathrm{E}-02$ & $<2.33 \mathrm{E}-02$ & $<2.12 \mathrm{E}-02$ & $<2.13 \mathrm{E}-02$ & $<2.46 \mathrm{E}-02$ \\
\hline 165 & $<2.1$ & & & & & & & & & & & & & & & \\
\hline 166 & $<2.15 \mathrm{E}-02$ & $<1$ & $<2$ & & & & & & & & & & & & & $<2$ \\
\hline 167 & $<2.15 \mathrm{E}-02$ & $<1.85 \mathrm{E}-02$ & $<2.54 \mathrm{E}-02$ & $<2.36 \mathrm{E}-02$ & $<2.19 \mathrm{E}-02$ & $<2.41 \mathrm{E}-02$ & $<2.05 \mathrm{E}-02$ & $4 \mathrm{E}-02$ & $<1.89 \mathrm{E}-02$ & $<2.45 \mathrm{E}-02$ & $<2$. & $<2$ & $<2$ & $<2.12 \mathrm{E}-02$ & $<2.13 \mathrm{E}-02$ & $<2.46 \mathrm{E}-02$ \\
\hline 168 & $<2.1$ & & & & & & & & & & & & & & & \\
\hline 169 & $<2.15 \mathrm{E}-02$ & $<1.85 \mathrm{E}-02$ & $<2.54 \mathrm{E}-02$ & $<2.36 \mathrm{E}-02$ & $<2.19 \mathrm{E}-02$ & $<2.41 \mathrm{E}-02$ & $<2.05 \mathrm{E}-02$ & $<2.54 \mathrm{E}-02$ & $<1.89 \mathrm{E}-02$ & $<2.45 \mathrm{E}-02$ & $<2.13 \mathrm{E}-02$ & $<2.18 \mathrm{E}-02$ & $<2.33 \mathrm{E}-02$ & $<2.12 \mathrm{E}-02$ & $<2.13 \mathrm{E}-02$ & $<2.46 \mathrm{E}-02$ \\
\hline 170 & $<2.1$ & $<1.8$ & $<2$ & $<2.36$ & & & & & & & & & & & & \\
\hline 1 & $<2.1$ & $<1.8$ & $<2$ & & & & & & & & & & & & $<2.13$ & $<2.46 \mathrm{E}-02$ \\
\hline 172 & $<2.15 \mathrm{E}-02$ & $<1.85 \mathrm{E}-02$ & $<2.54 \mathrm{E}-02$ & $<2.36 \mathrm{E}-02$ & $<2.19 \mathrm{E}-02$ & $<2.41 \mathrm{E}-02$ & $<2.05 \mathrm{E}-02$ & $<2.54 \mathrm{E}-02$ & $<1.89 \mathrm{E}-02$ & $<2.45 \mathrm{E}-02$ & $<2.13 \mathrm{E}-02$ & $<2.18 \mathrm{E}-02$ & $<2.33 \mathrm{E}-02$ & $<2.12 \mathrm{E}-02$ & $<2.13 \mathrm{E}-02$ & $<2.46 \mathrm{E}-02$ \\
\hline
\end{tabular}


Table A-2. ICP-MS of acid dilutions of sludge contact tests $(\mathrm{mg} / \mathrm{L})$, nominal uncertainty $=\mathbf{2 0} \%$ (contd.)

\begin{tabular}{|c|c|c|c|c|c|c|c|c|c|c|c|c|c|c|}
\hline hold time (days) & 0 & 0 & Standard 1 & 0 & 0 & 0 & 0 & Standard 2 & 7 & 7 & 7 & 7 & 7 & 7 \\
\hline glycolate $(\mathrm{g} / \mathrm{L})$ & 0 & 0 & 0 & 5 & 5 & 10 & 10 & 10 & 0 & 0 & 5 & 5 & 10 & 10 \\
\hline $\mathrm{DF}(\mathrm{mL} / \mathrm{mL})$ & 10.11 & 10.32 & 12.70 & 10.90 & 10.44 & 10.95 & 12.13 & 12.70 & 10.75 & 10.73 & 9.49 & 9.55 & 8.83 & 9.22 \\
\hline LIMS numbers & 300303312 & 300303313 & 300303314 & 300303315 & 300303316 & 300303317 & 300303318 & 300303319 & 300303297 & 300303298 & 300303299 & 300303300 & 300303301 & 300303302 \\
\hline $\operatorname{mass}(\mathrm{m} / \mathrm{z})=173$ & $<5.05 \mathrm{E}-02$ & $<5.16 \mathrm{E}-02$ & $<6.35 \mathrm{E}-02$ & $<5.45 \mathrm{E}-02$ & $<5.22 \mathrm{E}-02$ & $<5.48 \mathrm{E}-02$ & $<6.06 \mathrm{E}-02$ & $<6.35 \mathrm{E}-02$ & \begin{tabular}{|c|c|c|c|c|}
$<\mathrm{E}-02$ \\
\end{tabular} & $<2.15 \mathrm{E}-02$ & $<1.90 \mathrm{E}-02$ & $<1.91 \mathrm{E}-02$ & $<1.77 \mathrm{E}-02$ & $<1.84 \mathrm{E}-02$ \\
\hline 174 & $<5.05 \mathrm{E}-02$ & $<5.16 \mathrm{E}-02$ & $<6.35 \mathrm{E}-02$ & $<5.45 \mathrm{E}-02$ & $<5.22 \mathrm{E}-02$ & $<5.48 \mathrm{E}-02$ & $<6.06 \mathrm{E}-02$ & $<6.35 \mathrm{E}-02$ & $<2.15 \mathrm{E}-02$ & $<2.15 \mathrm{E}-02$ & $<1.90 \mathrm{E}-02$ & $<1.91 \mathrm{E}-02$ & $<1.77 \mathrm{E}-02$ & $<1.84 \mathrm{E}-02$ \\
\hline 175 & $<7.58 \mathrm{E}-02$ & $<7.74 \mathrm{E}-02$ & $<9.52 \mathrm{E}-02$ & $<8.18 \mathrm{E}-02$ & $<7.83 \mathrm{E}-02$ & $<8.21 \mathrm{E}-02$ & $<9.10 \mathrm{E}-02$ & $<9.52 \mathrm{E}-02$ & $<3.23 \mathrm{E}-02$ & $<3.22 \mathrm{E}-02$ & $<2.85 \mathrm{E}-02$ & $<2.87 \mathrm{E}-02$ & $<2.65 \mathrm{E}-02$ & $<2.77 \mathrm{E}-02$ \\
\hline 176 & $<5.05 \mathrm{E}-02$ & $<5.16 \mathrm{E}-02$ & $<6.35 \mathrm{E}-02$ & $<5.45 \mathrm{E}-02$ & $<5.22 \mathrm{E}-02$ & $<5.48 \mathrm{E}-02$ & $<6.06 \mathrm{E}-02$ & $<6.35 \mathrm{E}-02$ & $<2.15 \mathrm{E}-02$ & $<2.15 \mathrm{E}-02$ & $<1.90 \mathrm{E}-02$ & $<1.91 \mathrm{E}-02$ & $<1.77 \mathrm{E}-02$ & $<1.84 \mathrm{E}-02$ \\
\hline 177 & $<5.05 \mathrm{E}-02$ & $<5.16 \mathrm{E}-02$ & $<6.35 \mathrm{E}-02$ & $<5.45 \mathrm{E}-02$ & $<5.22 \mathrm{E}-02$ & $<5.48 \mathrm{E}-02$ & $<6.06 \mathrm{E}-02$ & $<6.35 \mathrm{E}-02$ & $<2.15 \mathrm{E}-02$ & $<2.15 \mathrm{E}-02$ & $<1.90 \mathrm{E}-02$ & $<1.91 \mathrm{E}-02$ & $<1.77 \mathrm{E}-02$ & $<1.84 \mathrm{E}-02$ \\
\hline 178 & $<5.05 \mathrm{E}-02$ & $<5.16 \mathrm{E}-02$ & $<6.35 \mathrm{E}-02$ & $<5.45 \mathrm{E}-02$ & $<5.22 \mathrm{E}-02$ & $<5.48 \mathrm{E}-02$ & $<6.06 \mathrm{E}-02$ & $<6.35 \mathrm{E}-02$ & $<2.15 \mathrm{E}-02$ & $<2.15 \mathrm{E}-02$ & $<1.90 \mathrm{E}-02$ & $<1.91 \mathrm{E}-02$ & $<1.77 \mathrm{E}-02$ & $<1.84 \mathrm{E}-02$ \\
\hline 179 & $<5.05 \mathrm{E}-02$ & $<5.16 \mathrm{E}-02$ & $<6.35 \mathrm{E}-02$ & $<5.45 \mathrm{E}-02$ & $<5.22 \mathrm{E}-02$ & $<5.48 \mathrm{E}-02$ & $<6.06 \mathrm{E}-02$ & $<6.35 \mathrm{E}-02$ & $<2.15 \mathrm{E}-02$ & $<2.15 \mathrm{E}-02$ & $<1.90 \mathrm{E}-02$ & $<1.91 \mathrm{E}-02$ & $<1.77 \mathrm{E}-02$ & $<1.84 \mathrm{E}-02$ \\
\hline 180 & $<5.05 \mathrm{E}-02$ & $<5.16 \mathrm{E}-02$ & $<6.35 \mathrm{E}-02$ & $<5.45 \mathrm{E}-02$ & $<5.22 \mathrm{E}-02$ & $<5.48 \mathrm{E}-02$ & $<6.06 \mathrm{E}-02$ & $<6.35 \mathrm{E}-02$ & $<2.15 \mathrm{E}-02$ & $<2.15 \mathrm{E}-02$ & $<1.90 \mathrm{E}-02$ & $<1.91 \mathrm{E}-02$ & $<1.77 \mathrm{E}-02$ & $<1.84 \mathrm{E}-02$ \\
\hline 181 & $<5.05 \mathrm{E}-02$ & $<5.16 \mathrm{E}-02$ & $<6.35 \mathrm{E}-02$ & $<5.45 \mathrm{E}-02$ & $<5.22 \mathrm{E}-02$ & $<5.48 \mathrm{E}-02$ & $<6.06 \mathrm{E}-02$ & $<6.35 \mathrm{E}-02$ & $<5.38 \mathrm{E}-02$ & $<5.37 \mathrm{E}-02$ & $<4.75 \mathrm{E}-02$ & $<4.78 \mathrm{E}-02$ & $<4.4$ & $<4.61 \mathrm{E}-02$ \\
\hline 182 & $2.85 \mathrm{E}-01$ & $2.81 \mathrm{E}-01$ & $<1.27 \mathrm{E}-01$ & $2.22 \mathrm{E}-01$ & $2.64 \mathrm{E}-01$ & $2.23 \mathrm{E}-01$ & $2.23 \mathrm{E}-01$ & $<1.27 \mathrm{E}-01$ & $2.33 \mathrm{E}-01$ & $2.23 \mathrm{E}-01$ & $2.07 \mathrm{E}-01$ & $2.13 \mathrm{E}-01$ & & $2.24 \mathrm{E}-01$ \\
\hline 183 & $1.26 \mathrm{E}-01$ & $1.46 \mathrm{E}-01$ & $<6.35 \mathrm{E}-02$ & 41E-01 & E-01 & $1.12 \mathrm{E}-01$ & $1.32 \mathrm{E}-01$ & $<6.35 \mathrm{E}-02$ & 01 & 01 & $1.39 \mathrm{E}-01$ & 1.08 & -01 & $1.57 \mathrm{E}-01$ \\
\hline 184 & $3.25 \mathrm{E}-01$ & 3.43E- 01 & $<1.90$ & & & & & $<1.90 \mathrm{E}-01$ & & & & 01 & & $2.42 \mathrm{E}-01$ \\
\hline 185 & $<5.05 \mathrm{E}-02$ & $<5.16 \mathrm{E}-02$ & $<6.35$ & 02 & $<5$ & $<5.4$ & $<6$. & & $<2$ & & $<1$. & & & $<1.84 \mathrm{E}-02$ \\
\hline 186 & $3.16 \mathrm{E}-01$ & $3.51 \mathrm{E}-01$ & $<2.54 \mathrm{E}-01$ & -01 & & $2.91 \mathrm{E}-01$ & $4.08 \mathrm{E}-01$ & $<2.54 \mathrm{E}-01$ & 2.6 & & $2.42 \mathrm{E}-01$ & 01 & & $2.08 \mathrm{E}-01$ \\
\hline 187 & $<2.27 \mathrm{E}-01$ & $<2.32 \mathrm{E}-01$ & $<2.86 \mathrm{E}-01$ & $<2.45 \mathrm{E}-01$ & E-01 & $<2.46 \mathrm{E}-01$ & $<2.73 \mathrm{E}-01$ & $<2.86 \mathrm{E}-01$ & $<3.23 \mathrm{E}-02$ & $<3$ & $<2.85 \mathrm{E}-02$ & $<2.87$ & -02 & $2.77 \mathrm{E}-02$ \\
\hline 191 & $5.90 \mathrm{E}-01$ & $3.45 \mathrm{E}-01$ & $7.21 \mathrm{E}-02$ & $3.06 \mathrm{E}-01$ & $5.82 \mathrm{E}-02$ & $<5.48 \mathrm{E}-02$ & $<6.06 \mathrm{E}-02$ & $1.16 \mathrm{E}+00$ & $<8.60 \mathrm{E}-02$ & $<8.59 \mathrm{E}-02$ & $<7.59 \mathrm{E}-02$ & $<7.64 \mathrm{E}-02$ & $<7.06 \mathrm{E}-02$ & $<7.37 \mathrm{E}-02$ \\
\hline 193 & $1.18 \mathrm{E}+00$ & $6.80 \mathrm{E}-01$ & $<2.22 \mathrm{E}-01$ & E-01 & $<1$. & $<1.92 \mathrm{E}-01$ & $<2.12 \mathrm{E}-01$ & $1.88 \mathrm{E}+00$ & $<8.60 \mathrm{E}-02$ & $<8$ & $<7$ & $<7$ & -02 & 7E-02 \\
\hline 194 & $<5.05 \mathrm{E}-02$ & $<5.16 \mathrm{E}-02$ & $<6.35 \mathrm{E}-02$ & $<5.45 \mathrm{E}-02$ & $<5.2$ & $<5.48 \mathrm{E}-02$ & $<6.06 \mathrm{E}-02$ & $<6.35 \mathrm{E}-02$ & $<2.1$ & -02 & $<1.90 \mathrm{E}-02$ & $<1.91 \mathrm{E}-02$ & -02 & $<1.84 \mathrm{E}-02$ \\
\hline 195 & $<5.05 \mathrm{E}-02$ & $<5.16 \mathrm{E}-02$ & $<6.35 \mathrm{E}-02$ & $<5.45 \mathrm{E}-02$ & $<5.22 \mathrm{E}-02$ & $<5.48 \mathrm{E}-02$ & $<6.06 \mathrm{E}-02$ & $<6.35 \mathrm{E}-02$ & $<3$ & $<3$ & $<2.85 \mathrm{E}-02$ & $<2.87$ & $<2$ & $<2.77 \mathrm{E}-02$ \\
\hline 196 & $1.92 \mathrm{E}-01$ & $2.64 \mathrm{E}-01$ & $<1.90 \mathrm{E}-01$ & & & 01 & & $<1.90 \mathrm{E}-01$ & & & & & & $2.39 \mathrm{E}-01$ \\
\hline 197 & $<9.60 \mathrm{E}-01$ & $<9.8$ & & 00 & $<9$ & $<1.0$ & $<1.1$ & $<1.21$ & $<9.1$ & $<9$. & $<8$ & 01 & $<7$. & $<7.83 \mathrm{E}-01$ \\
\hline 198 & & $1.30 \mathrm{E}+01$ & 44E-01 & & & & & & & & & & & +01 \\
\hline 203 & $<5.05 \mathrm{E}-02$ & $<5.16 \mathrm{E}-02$ & $<6.35 \mathrm{E}-02$ & $<5.45 \mathrm{E}-02$ & $<5.22 \mathrm{E}-02$ & $<5.48 \mathrm{E}-02$ & $<6.06 \mathrm{E}-02$ & $<6.35 \mathrm{E}-02$ & $<3.23 \mathrm{E}-02$ & $<3.22 \mathrm{E}-02$ & $<2.85 \mathrm{E}-02$ & $<2.8$ & $<2.6$ & $<2.77 \mathrm{E}-02$ \\
\hline 204 & $5.70 \mathrm{E}+00$ & $6.14 \mathrm{E}+00$ & $<1.59 \mathrm{E}-01$ & $6.27 \mathrm{E}+00$ & $5.96 \mathrm{E}+00$ & $5.84 \mathrm{E}+00$ & $5.98 \mathrm{E}+00$ & $<1.59 \mathrm{E}-01$ & $5.25 \mathrm{E}+00$ & $5.57 \mathrm{E}+00$ & $5.23 \mathrm{E}+00$ & $4.96 \mathrm{E}+00$ & $4.99 \mathrm{E}+00$ & $5.09 \mathrm{E}+00$ \\
\hline 205 & $<5.05 \mathrm{E}-02$ & $<5.16 \mathrm{E}-02$ & & $<5.45 \mathrm{E}-02$ & $<5.22 \mathrm{E}-02$ & $<5.48 \mathrm{E}-02$ & $<6.06 \mathrm{E}-02$ & & & & & & & $<2.77 \mathrm{E}-02$ \\
\hline 206 & $4.08 \mathrm{E}-01$ & $\mathrm{E}-01$ & $<9.52 \mathrm{E}-02$ & DE-01 & & $9.19 \mathrm{E}-02$ & 01 & l & & & 5.9 & & & 7.22E- 02 \\
\hline 207 & 4.12E-01 & 3.93E- 01 & $<1.90 \mathrm{E}-01$ & & & $<1.64 \mathrm{E}-01$ & $<1.82 \mathrm{E}-01$ & -01 & 02 & & 6.3 & & 8-02 & $6.43 \mathrm{E}-02$ \\
\hline 208 & $1.02 \mathrm{E}+00$ & $892 \mathrm{E}-01$ & $<6,35 \mathrm{E}-02$ & $09 \mathrm{~F}+00$ & & & & $683 \mathrm{E}_{0} 01$ & $<1.291$ & & $<1.1$ & & $1.79 \mathrm{E}-01$ & 36F-01 \\
\hline 230 & $<5.05 \mathrm{E}-02$ & $<5.16 \mathrm{E}-02$ & $<6.35 \mathrm{E}-02$ & $<5.45 \mathrm{E}-02$ & $<5.22 \mathrm{E}-02$ & $<5.48 \mathrm{E}-02$ & $<6.06 \mathrm{E}-02$ & $<6.35 \mathrm{E}-02$ & $<2.15 \mathrm{E}-02$ & $<2.1$ & $<1.90 \mathrm{E}-02$ & $<1.91 \mathrm{E}-02$ & $<1.7$ & $<1.84 \mathrm{E}-02$ \\
\hline 232 & $<5.0$ & $<5.16 \mathrm{E}-02$ & & $<5.4$ & $<5$ & $<5$. & $<6.06 \mathrm{E}-02$ & & & & & & & $<1.38 \mathrm{E}-01$ \\
\hline 233 & $<5.05 \mathrm{E}-02$ & $<5.16 \mathrm{E}-02$ & & & & & & & & & & & & $<184 \mathrm{~F}_{-} 0$ \\
\hline 234 & $<5.05 \mathrm{E}-02$ & $<5.16 \mathrm{E}-02$ & $<6.35 \mathrm{E}-02$ & $<5.45 \mathrm{E}-02$ & $<5.22 \mathrm{E}-02$ & $<5.48 \mathrm{E}-02$ & $<6.06 \mathrm{E}-02$ & $<6.35 \mathrm{E}-02$ & $<2.15 \mathrm{E}-02$ & $<2.15 \mathrm{E}-02$ & $<1.90 \mathrm{E}-02$ & $<1.91 \mathrm{E}-02$ & $<1.77 \mathrm{E}-02$ & $<1.84 \mathrm{E}-02$ \\
\hline 235 & & & & & & & & & & & & & & $1.99 \mathrm{E}-01$ \\
\hline 236 & $<5.05 \mathrm{E}-02$ & $<5.16 \mathrm{E}-$ & & & & $<5$ & $<6.0$ & & & & & & & $<1.84 \mathrm{E}-02$ \\
\hline 237 & $<5.05 \mathrm{E}-02$ & $<5.16 \mathrm{E}-02$ & $<6.35 \mathrm{E}-02$ & $<5.45 \mathrm{E}-02$ & $<5.22 \mathrm{E}-02$ & $<5.48 \mathrm{E}-02$ & $<6.06 \mathrm{E}-02$ & $<6.35 \mathrm{E}-02$ & $<3.23 \mathrm{E}-02$ & $<3.22 \mathrm{E}-02$ & $<2.85 \mathrm{E}-02$ & $<2.87 \mathrm{E}-02$ & $<2.65 \mathrm{E}-02$ & $<2.77 \mathrm{E}-02$ \\
\hline 238 & $5.36 \mathrm{E}+01$ & $5.55 \mathrm{E}+01$ & $<1.27 \mathrm{E}-01$ & $5.51 \mathrm{E}+01$ & & & & & & & & & & $3.21 \mathrm{E}+01$ \\
\hline 239 & $<5.05 \mathrm{E}-02$ & $<5.16 \mathrm{E}-02$ & $35 \mathrm{E}-02$ & $<5.45 \mathrm{E}-02$ & $<5.22 \mathrm{E}-02$ & $<5.48 \mathrm{E}-02$ & $<6.06 \mathrm{E}-02$ & & 02 & $1.02 \mathrm{E}-01$ & E-01 & $9.07 \mathrm{E}-02$ & -02 & $8.43 \mathrm{E}-02$ \\
\hline 240 & $<5.05 \mathrm{E}-02$ & $<5.16 \mathrm{E}-02$ & $<6.35 \mathrm{E}-02$ & $<5.45 \mathrm{E}-02$ & $<5.22 \mathrm{E}-02$ & $<5.48 \mathrm{E}-02$ & $<6.06 \mathrm{E}-02$ & $<6.35 \mathrm{E}-02$ & $<3.23 \mathrm{E}-02$ & $<3.22 \mathrm{E}-02$ & $<2.85 \mathrm{E}-02$ & $<2.87 \mathrm{E}-02$ & $<2.65 \mathrm{E}-02$ & $<2.77 \mathrm{E}-02$ \\
\hline 241 & $<5.05 \mathrm{E}-02$ & $<5.16 \mathrm{E}-02$ & & & & $<5$ & & & & & & & & \\
\hline 242 & $<5.05 \mathrm{E}-02$ & $<5.16 \mathrm{E}-02$ & $<6.35 \mathrm{E}-02$ & $<5.45 \mathrm{E}-02$ & $<5.22 \mathrm{E}-02$ & $<5.48 \mathrm{E}-02$ & $<6.06 \mathrm{E}-02$ & $<6.35 \mathrm{E}-02$ & $<2.15 \mathrm{E}-02$ & $<2.15 \mathrm{E}-02$ & $<1.90 \mathrm{E}-02$ & $<1.91 \mathrm{E}-02$ & $<1.77$ E- 02 & $<1.84 \mathrm{E}-02$ \\
\hline 243 & $<5.05 \mathrm{E}-02$ & $<5.16 \mathrm{E}-02$ & $<6.35 \mathrm{E}-02$ & $<5.45 \mathrm{E}-02$ & $<5.22 \mathrm{E}-02$ & $<5.48 \mathrm{E}-02$ & $<6.06 \mathrm{E}-02$ & $<6.35 \mathrm{E}-02$ & $<2.15 \mathrm{E}-02$ & $<2.15 \mathrm{E}-02$ & $<1.90 \mathrm{E}-02$ & $<1.91 \mathrm{E}-02$ & $<1.77 \mathrm{E}-02$ & $<1.84 \mathrm{E}-02$ \\
\hline 244 & $<5.05 \mathrm{E}-02$ & $<5.16 \mathrm{E}-02$ & $<6.35 \mathrm{E}-02$ & $<5.45 \mathrm{E}-02$ & $<5.22 \mathrm{E}-02$ & $<5.48 \mathrm{E}-02$ & $<6.06 \mathrm{E}-02$ & $<6.35 \mathrm{E}-0$ & $<4.30 \mathrm{E}-02$ & $<4.29 \mathrm{E}-02$ & $<3.80 \mathrm{E}-02$ & $<3.82 \mathrm{E}-02$ & $<3.53 \mathrm{E}-02$ & $<3.69 \mathrm{E}-02$ \\
\hline
\end{tabular}


Table A-2. ICP-MS of acid dilutions of sludge contact tests $(\mathrm{mg} / \mathrm{L}$ ), nominal uncertainty $=\mathbf{2 0} \%$ (contd.)

\begin{tabular}{|c|c|c|c|c|c|c|c|c|c|c|c|c|c|c|c|c|}
\hline lays) & 14 & 14 & tandard 1 & 14 & 14 & 14 & 14 & andard 2 & 14 & 14 & 21 & 21 & 21 & 21 & 21 & 21 \\
\hline$(\mathrm{g} / \mathrm{L})$ & 0 & 0 & 0 & 5 & 5 & 10 & 10 & 10 & 0.2 & 0.2 & 0 & 0 & $J$ & 5 & 10 & 10 \\
\hline $\mathrm{DF}(\mathrm{mL} / \mathrm{mL})$ & 10.44 & 10.89 & 12.70 & 9.77 & 9.80 & 9.31 & 10.10 & 12.70 & 11.77 & 10.41 & 11.26 & 10.68 & 9.35 & 10.07 & 11.21 & 11.60 \\
\hline LIMS numbers & 300303331 & 300303332 & 300303333 & 300303334 & 300303335 & 300303336 & 300303337 & 300303338 & 300303339 & 300303340 & 300303355 & 300303356 & 300303357 & 300303358 & 300303359 & 300303360 \\
\hline $\operatorname{mass}(\mathrm{m} / \mathrm{z})=173$ & $<2.09 \mathrm{E}-02$ & $<2.18 \mathrm{E}-02$ & $<2.54 \mathrm{E}-02$ & $<1.95 \mathrm{E}-02$ & $<1.96 \mathrm{E}-02$ & $<1.86 \mathrm{E}-02$ & $<2.02 \mathrm{E}-02$ & $<2.54 \mathrm{E}-02$ & $<2.35 \mathrm{E}-02$ & $<2.08 \mathrm{E}-02$ & $<2.25 \mathrm{E}-02$ & $<2.14 \mathrm{E}-02$ & $<1.87 \mathrm{E}-02$ & $<2.01 \mathrm{E}-02$ & $<2.24 \mathrm{E}-02$ & $<2.32 \mathrm{E}-02$ \\
\hline 174 & $<2.09 \mathrm{E}-02$ & $<2.18 \mathrm{E}-02$ & $<2.54 \mathrm{E}-02$ & $<1.95 \mathrm{E}-02$ & $<1.96 \mathrm{E}-02$ & $<1.86 \mathrm{E}-02$ & $<2.02 \mathrm{E}-02$ & $<2.54 \mathrm{E}-02$ & $<2.35 \mathrm{E}-02$ & $<2.08 \mathrm{E}-02$ & $<2.25 \mathrm{E}-02$ & $<2.14 \mathrm{E}-02$ & $<1.87 \mathrm{E}-02$ & $<2.01 \mathrm{E}-02$ & $<2.24 \mathrm{E}-02$ & $<2.32 \mathrm{E}-02$ \\
\hline 175 & $<2.09 \mathrm{E}-02$ & $<2.1$ & $2.54 \mathrm{E}-02$ & $<1.95 \mathrm{E}-02$ & $<1.96 \mathrm{E}-02$ & $<1.86 \mathrm{E}-02$ & $<2.02$ E- 02 & $<2.54 \mathrm{E}-02$ & $<2.35 \mathrm{E}-02$ & $<2.08 \mathrm{E}-02$ & -02 & & & & & \\
\hline 176 & $<2.09 \mathrm{E}-02$ & $<2.18 \mathrm{E}-02$ & $<2.54 \mathrm{E}-02$ & $<1.95 \mathrm{E}-02$ & $<1.96 \mathrm{E}-02$ & $<1.86 \mathrm{E}-02$ & $<2.02 \mathrm{E}-02$ & $<2.54 \mathrm{E}-02$ & $<2.35 \mathrm{E}-02$ & $<2.08 \mathrm{E}-02$ & $<2.25 \mathrm{E}-02$ & $<2.14 \mathrm{E}-02$ & $<1.87 \mathrm{E}-02$ & $<2.01 \mathrm{E}-02$ & $<2.24 \mathrm{E}-02$ & $<2.32 \mathrm{E}-02$ \\
\hline 177 & $<2.09 \mathrm{E}-02$ & $<2.18 \mathrm{E}-02$ & $<2.54 \mathrm{E}-02$ & $<1.95 \mathrm{E}-02$ & $<1.96 \mathrm{E}-02$ & $<1.86 \mathrm{E}-02$ & $<2.02 \mathrm{E}-02$ & $<2.54 \mathrm{E}-02$ & $<2.35 \mathrm{E}-02$ & $<2.08 \mathrm{E}-02$ & $<2.25 \mathrm{E}-02$ & $<2.14 \mathrm{E}-02$ & $<1.87 \mathrm{E}-02$ & $<2.01 \mathrm{E}-02$ & $<2.24 \mathrm{E}-02$ & $<2.32 \mathrm{E}-02$ \\
\hline 178 & $<2.09 \mathrm{E}-02$ & $<2.18 \mathrm{E}-02$ & $<2.54 \mathrm{E}-02$ & $<1.95 \mathrm{E}-02$ & $<1.96 \mathrm{E}-02$ & $<1.86 \mathrm{E}-02$ & $<2.02 \mathrm{E}-02$ & $<2.54 \mathrm{E}-02$ & $<2.35 \mathrm{E}-02$ & $<2.08 \mathrm{E}-02$ & $<2.2$ & & & $<2.01 \mathrm{E}-02$ & & \\
\hline 179 & $<2.09 \mathrm{E}-02$ & $<2.18 \mathrm{E}-02$ & $<2.54 \mathrm{E}-02$ & $<1.95 \mathrm{E}-02$ & $<1.96 \mathrm{E}-02$ & $<1.86 \mathrm{E}-02$ & $<2.02 \mathrm{E}-02$ & $<2.54 \mathrm{E}-02$ & $<2.35 \mathrm{E}-02$ & $<2.08 \mathrm{E}-02$ & $<2.25$ & $<2.1$ & $<1.87 \mathrm{E}-02$ & $<2.0$ & $<2.2$ & $<2.32 \mathrm{E}-02$ \\
\hline 180 & $<2.09 \mathrm{E}-02$ & $<2.18$ & $<2.54 \mathrm{E}-02$ & $<1.95$ & $<1.96$ & $<1.86 \mathrm{l}$ & $<2.02 \mathrm{E}-02$ & -02 & $<2.35$ & $<2.08$ & $<2.2$ & & $<1.8$ & $<2.0$ & & \\
\hline 181 & $<2.09 \mathrm{E}-02$ & $<2.18 \mathrm{E}-02$ & $<2.54 \mathrm{E}-02$ & $<1.95 \mathrm{E}-02$ & $<1.96 \mathrm{E}-02$ & $<1.86 \mathrm{E}-02$ & $<2.02 \mathrm{E}-02$ & $<2.54 \mathrm{E}-02$ & $<2.35 \mathrm{E}-02$ & $<2.08 \mathrm{E}-02$ & $<2.2$ & & $<1.8$ & & & \\
\hline 182 & $2.62 \mathrm{E}-01$ & & 02 & 2.5 & 2.7 & 01 & $2.21 \mathrm{E}-01$ & & & -01 & & & & & & $2.11 \mathrm{E}-01$ \\
\hline 183 & & & & & & & & & & & & & & & & \\
\hline 184 & 2. & & & & 1 & 1 & 01 & & & & & & & & & E-01 \\
\hline 185 & $<2.09 \mathrm{E}-02$ & $<2.1$ & $<2.54$ & $<1.95$ & $<1.96$ & $<1.861$ & $<2.02 \mathrm{E}-02$ & & & -02 & & & & 02 & & -02 \\
\hline 186 & & & & & & & & & & & & & & & & \\
\hline 187 & $<2.09 \mathrm{E}-02$ & $<2$. & $<2.54 \mathrm{E}-02$ & $<1.95 \mathrm{E}-02$ & $<1.96 \mathrm{E}-02$ & $<1.86 \mathrm{E}-02$ & $<2.02 \mathrm{E}-02$ & $<2.54 \mathrm{E}-02$ & $<2$ & $<2.08 \mathrm{E}-02$ & $<4$. & & & $<4.0$ & -02 & $<4.64 \mathrm{E}-02$ \\
\hline 191 & $<3.1$ & $<3.2$ & & $<2.9$ & $<2$ & & $<3.03 \mathrm{E}-02$ & & & $<3.1$ & & & & & & \\
\hline 193 & $<4.17$ & $<4.3$ & & $<3.91$ & $<3.9$ & 02 & 02 & & & $<4$ & & & & & & \\
\hline 194 & $<2.09 \mathrm{E}-02$ & $<2.1$ & $<2.54 \mathrm{E}-02$ & $<1.95$ & $<1.96$ & $<1.8$ & $<2.02 \mathrm{E}-02$ & $<2$ & & $<2$. & & & & & & $\mathrm{E}-02$ \\
\hline 195 & $<2.09 \mathrm{E}-02$ & $<2.1$ & $<2.54 \mathrm{E}-02$ & $<1.95$ & $<1.9$ & $<1.8$ & $\mathrm{E}-02$ & & $<2$ & $<2$ & $<3$ & & & $<3$ & & $\mathrm{E}-02$ \\
\hline 196 & $1.91 \mathrm{E}-01$ & & -02 & & & & & & & & & & & & & \\
\hline 197 & $<1.77 \mathrm{E}-01$ & $<1.8$ & $<2.1$ & $<1.66 \mathrm{E}-01$ & $<1.6$ & 1.5 & -01 & 01 & $<2$. & $<1$. & & & & & & \\
\hline 198 & & & & & & & & & & & & & & & & $9.90 \mathrm{E}+00$ \\
\hline 203 & $<3.13 \mathrm{E}-02$ & $<3$. & & $<2$ & $<2$ & & & & & & & & & & & $<2.32 \mathrm{E}-02$ \\
\hline 204 & & & & & & & & & & & & & & & & \\
\hline 205 & $<2.09 \mathrm{E}-02$ & $<2.18 \mathrm{E}-02$ & & $<1.95 \mathrm{E}-02$ & $<1.9$ & $<1.8$ & $<2$ & 02 & $<2.3$ & $<2.0$ & & $<2.1$ & $<1$. & $<2$ & & \\
\hline 206 & & & & & & & & & & & & & & & & $8-02$ \\
\hline 207 & & & $<3$ & & & & & & & & & -02 & -02 & -02 & -02 & $<8.12 \mathrm{E}-02$ \\
\hline 208 & & & & & & & & & & & & & & & & \\
\hline 230 & $<2.09 \mathrm{E}-02$ & $<2$. & & $<1.95$ & $<1.96$ & 02 & & & $<2$ & $<2$. & & & & & & -02 \\
\hline 232 & $<2.09 \mathrm{E}-02$ & $<2.18 \mathrm{E}-02$ & $54 \mathrm{E}-02$ & $<1.95 \mathrm{E}-02$ & $<1.96 \mathrm{E}-02$ & & $<2.02 \mathrm{E}-02$ & -02 & $<2.35 \mathrm{E}-02$ & $<2.08 \mathrm{E}-02$ & $2.25 \mathrm{E}-02$ & $<2.14 \mathrm{E}-02$ & $<1.87 \mathrm{E}-02$ & $<2.01 \mathrm{E}-02$ & $<2.24 \mathrm{E}-02$ & $<2.32 \mathrm{E}-02$ \\
\hline 233 & & & & & & & & & & & & & & & & \\
\hline 234 & $<2.09 \mathrm{E}-02$ & $<2.18 \mathrm{E}-02$ & $<2.54 \mathrm{E}-02$ & $<1.95 \mathrm{E}-02$ & $<1.96 \mathrm{E}-02$ & $<1.86 \mathrm{E}-02$ & $<2.02 \mathrm{E}-02$ & $4 \mathrm{E}-02$ & $<2$. & $<2.08 \mathrm{E}-02$ & 02 & $<2$ & $<1$. & .02 & $<2.2$ & $<2.32 \mathrm{E}-02$ \\
\hline 235 & & & & & & & & & & & & & & & & \\
\hline 236 & $<2$. & $<2$. & & & & & & & & & & & & & & 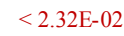 \\
\hline 237 & $<2.09 \mathrm{E}-02$ & $<2.18 \mathrm{E}-02$ & $<2.54 \mathrm{E}-02$ & $<1.95 \mathrm{E}-02$ & $<1.96 \mathrm{E}-02$ & $<1.86 \mathrm{E}-02$ & $<2.02 \mathrm{E}-02$ & $<2.54 \mathrm{E}-02$ & $<2.35 \mathrm{E}-02$ & $<2.08 \mathrm{E}-02$ & $<2.25 \mathrm{E}-02$ & $<2.14$ & $<1.87 \mathrm{E}-02$ & $<2.01 \mathrm{E}-02$ & $<2.24 \mathrm{E}-02$ & $<2.32 \mathrm{E}-02$ \\
\hline 238 & & & & & & & & & & & & & & & & \\
\hline 239 & $<2.09 \mathrm{E}-02$ & $<2.1$ & & 02 & $<1$ & $<1$ & & & $<2$ & $<2$. & & & & & $<2$ & -02 \\
\hline 240 & $<2.09 \mathrm{E}-02$ & $<2.18 \mathrm{E}-02$ & $<2.54 \mathrm{E}-02$ & $<1.95 \mathrm{E}-02$ & $<1.96 \mathrm{E}-02$ & $<1.86 \mathrm{E}-02$ & $<2.02$ E- 02 & 02 & $<2.35 \mathrm{E}-02$ & $<2.08 \mathrm{E}-02$ & 02 & $<2$ & -02 & .02 & -02 & $<2.32 \mathrm{E}-02$ \\
\hline 241 & & & & & & & & & & & & & & & & \\
\hline 242 & $<2.09 \mathrm{E}-02$ & $<2.18 \mathrm{E}-02$ & $<2.54 \mathrm{E}-02$ & $<1.95 \mathrm{E}-02$ & $<1.96 \mathrm{E}-02$ & $<1.86 \mathrm{E}-02$ & $<2.02 \mathrm{E}-02$ & $<2.54 \mathrm{E}-02$ & $<2.35 \mathrm{E}-02$ & $<2.08 \mathrm{E}-02$ & $<2.25 \mathrm{E}-02$ & $<2.14 \mathrm{E}-02$ & $<1.87 \mathrm{E}-02$ & $<2.01 \mathrm{E}-02$ & $<2.24 \mathrm{E}-02$ & $<2.32 \mathrm{E}-02$ \\
\hline 243 & $<2.09 \mathrm{E}-02$ & $<2.18 \mathrm{E}-02$ & & & & & & & & & & & & & & \\
\hline 244 & $<2.09 \mathrm{E}-02$ & $<2.18 \mathrm{E}-02$ & $<2.54 \mathrm{E}-02$ & $<1.95 \mathrm{E}-02$ & $<1.96 \mathrm{E}-02$ & $<1.86 \mathrm{E}-02$ & $<2.02 \mathrm{E}-02$ & $<2.54 \mathrm{E}-02$ & $<2.3$ & $<2.0$ & $<2$ & $<2.14 \mathrm{E}-02$ & $<1.87 \mathrm{E}-02$ & $<2.01 \mathrm{E}-02$ & $<2.24 \mathrm{E}-02$ & $<2.32 \mathrm{E}-02$ \\
\hline
\end{tabular}


Table A-2. ICP-MS of acid dilutions of sludge contact tests $(\mathrm{mg} / \mathrm{L}$ ), nominal uncertainty $=\mathbf{2 0} \%$ (contd.)

\begin{tabular}{|c|c|c|c|c|c|c|c|c|c|c|c|c|c|c|c|c|}
\hline ays) & 35 & 35 & andard 1 & 35 & 35 & 35 & 35 & andard 2 & 35 & 35 & 35 & 35 & 35 & 35 & 35 & 35 \\
\hline$e(g / L)$ & 0 & 0 & 0 & 5 & 5 & 10 & 10 & 10 & 0.2 & 0.2 & 0 & 0 & 5 & 5 & 10 & 10 \\
\hline $\mathrm{DF}(\mathrm{mL} / \mathrm{mL})$ & 10.74 & 9.26 & 12.70 & 11.78 & 10.95 & 12.04 & 10.23 & 12.70 & 9.45 & 12.27 & 10.65 & 10.91 & 11.65 & 10.58 & 10.65 & 12.28 \\
\hline LIMS numbers & 300303385 & 300303386 & 300303387 & 300303388 & 300303389 & 300303390 & 300303391 & 300303392 & 300303393 & 300303394 & 300303395 & 300303396 & 300303397 & 300303398 & 300303399 & 300303400 \\
\hline $\operatorname{mass}(\mathrm{m} / \mathrm{z})=173$ & $<2.15 \mathrm{E}-02$ & $<1.85 \mathrm{E}-02$ & $<2.54 \mathrm{E}-02$ & $<2.36 \mathrm{E}-02$ & $<2.19 \mathrm{E}-02$ & $<2.41 \mathrm{E}-02$ & $<2.05 \mathrm{E}-02$ & $<2.54 \mathrm{E}-02$ & $<1.89 \mathrm{E}-02$ & $<2.45 \mathrm{E}-02$ & $<2.13 \mathrm{E}-02$ & $<2.18 \mathrm{E}-02$ & $<2.33 \mathrm{E}-02$ & $<2.12 \mathrm{E}-02$ & $<2.13 \mathrm{E}-02$ & $<2.46 \mathrm{E}-02$ \\
\hline 174 & $<2.15 \mathrm{E}-02$ & $<1.85 \mathrm{E}-02$ & $<2.54 \mathrm{E}-02$ & $<2.36 \mathrm{E}-02$ & $<2.19 \mathrm{E}-02$ & $<2.41 \mathrm{E}-02$ & $<2.05 \mathrm{E}-02$ & $<2.54 \mathrm{E}-02$ & $<1.89 \mathrm{E}-02$ & $<2.45 \mathrm{E}-02$ & $<2.13 \mathrm{E}-02$ & $<2.18 \mathrm{E}-02$ & $<2.33 \mathrm{E}-02$ & $<2.12 \mathrm{E}-02$ & $<2.13 \mathrm{E}-02$ & $<2.46 \mathrm{E}-02$ \\
\hline 175 & $<2.15 \mathrm{E}-02$ & $<1.85$ & $<2.54 \mathrm{E}-02$ & $<2.36 \mathrm{E}-02$ & $<2.19 \mathrm{E}-02$ & $<2.41 \mathrm{E}-02$ & & $\mathrm{E}-02$ & $<1.89 \mathrm{E}-02$ & $5 \mathrm{E}-02$ & -02 & & & & & \\
\hline 176 & $<2.15 \mathrm{E}-02$ & $<1.85 \mathrm{E}-02$ & $<2.54 \mathrm{E}-02$ & $<2.36 \mathrm{E}-02$ & $<2.19 \mathrm{E}-02$ & $<2.41 \mathrm{E}-02$ & $<2.05 \mathrm{E}-02$ & $<2.54 \mathrm{E}-02$ & $<1.89 \mathrm{E}-02$ & $<2.45 \mathrm{E}-02$ & $<2.13 \mathrm{E}-02$ & $<2.18 \mathrm{E}-02$ & $<2.33 \mathrm{E}-02$ & $<2.12 \mathrm{E}-02$ & $<2.13 \mathrm{E}-02$ & $<2.46 \mathrm{E}-02$ \\
\hline 177 & $<2.15 \mathrm{E}-02$ & $<1.85 \mathrm{E}-02$ & $<2.54 \mathrm{E}-02$ & $<2.36 \mathrm{E}-02$ & $<2.19 \mathrm{E}-02$ & $<2.41 \mathrm{E}-02$ & $<2.05 \mathrm{E}-02$ & $<2.54 \mathrm{E}-02$ & $<1.89 \mathrm{E}-02$ & $<2.45 \mathrm{E}-02$ & $<2.13 \mathrm{E}-02$ & $<2.18 \mathrm{E}-02$ & $<2.33 \mathrm{E}-02$ & $<2.12 \mathrm{E}-02$ & $<2.13 \mathrm{E}-02$ & $<2.46 \mathrm{E}-02$ \\
\hline 178 & $<2.15 \mathrm{E}-02$ & $<1.85 \mathrm{E}-02$ & $<2.54 \mathrm{E}-02$ & $<2.36 \mathrm{E}-02$ & $<2.19 \mathrm{E}-02$ & $<2.41 \mathrm{E}-02$ & $<2.05 \mathrm{E}-02$ & $<2.54 \mathrm{E}-02$ & $<1.89 \mathrm{E}-02$ & $<2.45 \mathrm{E}-02$ & $<5.3$ & $<5.45 \mathrm{E}-02$ & $<5.83 \mathrm{E}-02$ & & & \\
\hline 179 & $<2.15 \mathrm{E}-02$ & $<1.85 \mathrm{E}-02$ & $<2.54 \mathrm{E}-02$ & $<2.36 \mathrm{E}-02$ & $<2.19 \mathrm{E}-02$ & $<2.41 \mathrm{E}-02$ & $<2.05 \mathrm{E}-02$ & $<2.54 \mathrm{E}-02$ & $<1.89 \mathrm{E}-02$ & $<2.45 \mathrm{E}-02$ & $<2.1$ & $<2.18 \mathrm{E}-02$ & $<2.33 \mathrm{E}-02$ & $<2.12 \mathrm{E}-02$ & $<2.1$ & $<2.46 \mathrm{E}-02$ \\
\hline 180 & $<4.30 \mathrm{E}-02$ & $<3.70 \mathrm{E}-02$ & $<5.08 \mathrm{E}-02$ & $<4.71$ & $<4.3$ & $<4.82$ & $<4.0$ & $<5.0$ & $<3.78$ & $<4$. & & $<2.18$ & $<2.3$ & & & \\
\hline 181 & $<2.15 \mathrm{E}-02$ & $<1.85 \mathrm{E}-02$ & $<2.54 \mathrm{E}-02$ & $<2.36 \mathrm{E}-02$ & $<2.19$ & $<2.41 \mathrm{E}-02$ & $<2.05 \mathrm{E}-02$ & $<2.54 \mathrm{E}-02$ & $<1.89 \mathrm{E}-02$ & $<2.45 \mathrm{E}-02$ & $<4.2$ & & & & & \\
\hline 182 & $2.51 \mathrm{E}-01$ & E-01 & $<1.27 \mathrm{E}-01$ & & & & & $\mathrm{E}-01$ & 2.4 & -01 & & & & & & $.28 \mathrm{E}-01$ \\
\hline 183 & & & & & & & & & & & & & & & & \\
\hline 184 & -01 & & & & & & & & & & & & & & & \\
\hline 185 & $<3.22 \mathrm{E}-02$ & $8-02$ & $<3.81$ & $<3$ & $<3$ & 02 & & 02 & 02 & & & & & & & \\
\hline 186 & & & & & & & & & & & & & & & & \\
\hline 187 & $<2.15 \mathrm{E}-02$ & $<1.85 \mathrm{E}-02$ & $<2.54 \mathrm{E}-02$ & $<2.3$ & $<2.19 \mathrm{E}-02$ & $<2$ & $\mathrm{E}-02$ & $<2.54 \mathrm{E}-02$ & $<1.89 \mathrm{E}-02$ & $<2.45 \mathrm{E}-02$ & $<2$. & $<2.1$ & & & & $<2.46 \mathrm{E}-02$ \\
\hline 191 & $<6.44 \mathrm{E}-02$ & $<5$. & $<7.62 \mathrm{E}-02$ & $<7$. & $<6$. & & & & $<5$. & & & & & & & \\
\hline 193 & $<6.44$ & $<5.5$ & $<7.62 \mathrm{E}-02$ & $<7.0$ & $<6$. & 02 & 02 & -02 & $<5.6$ & & & & & & & -02 \\
\hline 194 & $<2.15 \mathrm{E}-02$ & $<1.85 \mathrm{E}-02$ & $<2.54 \mathrm{E}-02$ & $<2.3$ & $<2$. & & & & $<1$. & & & & & & & E- 02 \\
\hline 195 & $<2.15 \mathrm{E}-02$ & $<1.8$ & $<2.54 \mathrm{E}-02$ & $<2.3$ & $<2$. & $<2$ & $<2$ & & $<1.8$ & & $<2$ & $<2$ & & & & $<2$. \\
\hline 196 & $2.06 \mathrm{E}-01$ & & $<2$ & & & & & & & & & & & & & -01 \\
\hline 197 & $<2.79 \mathrm{E}-01$ & $<2.4$ & & $<3.0$ & $<2$ & $<3$. & $<2$ & -01 & $<2$. & $<3$. & & & & & & 81 \\
\hline 198 & & & & & & & & & 100 & +00 & & +00 & & & & $8.76 \mathrm{E}+00$ \\
\hline 203 & $<2.15 \mathrm{E}-02$ & $<1.85 \mathrm{E}-02$ & & $<2$. & & & & & & & & & & & & $<2.46 \mathrm{E}-02$ \\
\hline 204 & 4.6 & & & & & & & & & & & & & & & 4.1 \\
\hline 205 & $<2.15 \mathrm{E}-02$ & $<1.85 \mathrm{E}-02$ & $<2.54 \mathrm{E}-02$ & $<2$ & $<2$. & $<2$ & $<2$ & & $<1.89$ & $<2.4$ & $<2$ & $<2.18$ & $<2$ & & & \\
\hline 206 & -02 & & & & & & & & & & & & & & & \\
\hline 207 & & & $<3.8$ & & & & & & & & & & & & & $8-02$ \\
\hline 208 & & & & & & & & & & & & & & & & \\
\hline 230 & $<2.15$ & $<1$. & & $<2$ & 02 & & & & $<1.8$ & $<2$. & 02 & $<2$ & & & $<2$ & -02 \\
\hline 232 & $<2.15 \mathrm{E}-02$ & $<1.85 \mathrm{E}-02$ & $54 \mathrm{E}-02$ & $<2.3$ & $<2$. & 02 & -02 & $.54 \mathrm{E}-02$ & $<1.89 \mathrm{E}-02$ & $<2.45 \mathrm{E}-02$ & -02 & $<2.18 \mathrm{E}-02$ & $<2.33 \mathrm{E}-02$ & $<2.12 \mathrm{E}-02$ & $<2.13 \mathrm{E}-02$ & $<2.46 \mathrm{E}-02$ \\
\hline 233 & & & $<2.54 \mathrm{E}-02$ & & & & & & & & & & & & & \\
\hline 234 & $<2.15 \mathrm{E}-02$ & $<1.85 \mathrm{E}-02$ & $<2.54 \mathrm{E}-02$ & $<2.36 \mathrm{E}-02$ & $<2.19 \mathrm{E}-02$ & $<2.41 \mathrm{E}-02$ & $<2.05 \mathrm{E}-02$ & $54 \mathrm{E}-02$ & $<1.89 \mathrm{E}-02$ & $<2.45 \mathrm{E}-02$ & $<2$. & $<2.18 \mathrm{E}-02$ & $<2$ & .02 & $<2$. & $<2.46 \mathrm{E}-02$ \\
\hline 235 & & & & & & & & & & & & & & & & $2 \mathrm{E}-02$ \\
\hline 236 & $<2$. & $<1$. & & & & & 02 & & & & & & & & & 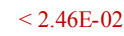 \\
\hline 237 & $<2.15 \mathrm{E}-02$ & $<1.85 \mathrm{E}-02$ & $<2.54 \mathrm{E}-02$ & $<2.36 \mathrm{E}-02$ & $<2.19 \mathrm{E}-02$ & $<2.41 \mathrm{E}-02$ & $<2.05 \mathrm{E}-02$ & $<2.54 \mathrm{E}-02$ & $<1.89 \mathrm{E}-02$ & $<2.45 \mathrm{E}-02$ & $<2.1$ & $<2.18 \mathrm{E}-02$ & $<2.33 \mathrm{E}-02$ & $<2.12 \mathrm{E}-02$ & $<2.13 \mathrm{E}-02$ & $<2.46 \mathrm{E}-02$ \\
\hline 238 & & & & & & & & & & & & & & & & \\
\hline 239 & $<2.15 \mathrm{E}-02$ & $<1$. & $<2.54 \mathrm{E}-02$ & $<2.36 \mathrm{E}-02$ & $<2$ & $<2$. & $<2$ & & $<1.8$ & $<2$ & & & & & & $<2$ \\
\hline 240 & $<2.15 \mathrm{E}-02$ & $<1.85 \mathrm{E}-02$ & $<2.54 \mathrm{E}-02$ & $<2.36 \mathrm{E}-02$ & $<2.19 \mathrm{E}-02$ & $<2.41 \mathrm{E}$ & $<2.05 \mathrm{E}-02$ & $<2.54 \mathrm{E}-02$ & $<1.89 \mathrm{E}-02$ & $<2.45 \mathrm{E}-02$ & $<2$. & $<2$. & $<2$ & $<2$ & $<2$. & $<2.46 \mathrm{E}-02$ \\
\hline 241 & & & & & & & & & & & & & & & & \\
\hline 242 & $<2.15 \mathrm{E}-02$ & $<1.85 \mathrm{E}-02$ & $<2.54 \mathrm{E}-02$ & $<2.36 \mathrm{E}-02$ & $<2.19 \mathrm{E}-02$ & $<2.41 \mathrm{E}-02$ & $<2.05 \mathrm{E}-02$ & $<2.54 \mathrm{E}-02$ & $<1.89 \mathrm{E}-02$ & $<2.45 \mathrm{E}-02$ & $<2.13 \mathrm{E}-02$ & $<2.18 \mathrm{E}-02$ & $<2.33 \mathrm{E}-02$ & $<2.12 \mathrm{E}-02$ & $<2.13 \mathrm{E}-02$ & $<2.46 \mathrm{E}-02$ \\
\hline 243 & $<2.15 \mathrm{E}-02$ & & & & & & & & & & & & & & & \\
\hline 244 & $<2.15 \mathrm{E}-02$ & $<1.85 \mathrm{E}-02$ & $<2.54 \mathrm{E}-02$ & $<2.36 \mathrm{E}-02$ & $<2.19 \mathrm{E}-02$ & $<2.41 \mathrm{E}-02$ & $<2.05 \mathrm{E}-02$ & $<2.54 \mathrm{E}-02$ & $<1.89 \mathrm{E}-02$ & $<2.45$ & $<2$. & $<2.18 \mathrm{E}-02$ & $\mathrm{E}-02$ & $<2.12 \mathrm{E}-02$ & $<2.13 \mathrm{E}-02$ & $<2.46 \mathrm{E}-\mathrm{C}$ \\
\hline
\end{tabular}


Table A-3. Analysis of water dilutions for sludge contact testing

\begin{tabular}{|c|c|c|c|c|c|c|c|c|c|c|c|c|c|c|}
\hline hold time (days) & 0 & Standard 1 & 0 & 0 & Standard 2 & 7 & 7 & 7 & 14 & Standard 1 & 14 & 14 & Standard 2 & 14 \\
\hline glycolate $(\mathrm{g} / \mathrm{L})$ & 0 & 0 & 5 & 10 & 10 & 0 & 5 & 10 & 0 & 0 & 5 & 10 & 10 & 0.2 \\
\hline $\mathrm{DF}(\mathrm{mL} / \mathrm{mL})$ & 10.29 & 13.52 & 10.63 & 10.50 & 13.51 & 11.26 & 10.41 & 12.04 & 9.64 & 13.52 & 10.53 & 9.24 & 13.51 & 8.94 \\
\hline LIMS number & 300303326 & 300303327 & 300303328 & 300303329 & 300303330 & 300303309 & 300303310 & 300303311 & 300303349 & 300303353 & 300303350 & 300303351 & 300303354 & 300303352 \\
\hline \multicolumn{15}{|c|}{ IC Anions (mg/L) } \\
\hline Glycolate & $<5.14 \mathrm{E}+02$ & $<6.76 \mathrm{E}+02$ & $5.75 \mathrm{E}+03$ & $1.55 \mathrm{E}+04$ & $8.75 \mathrm{E}+03$ & $<1.13 \mathrm{E}+03$ & $4.41 \mathrm{E}+03$ & $8.75 \mathrm{E}+03$ & $<9.64 \mathrm{E}+02$ & $<1.35 \mathrm{E}+03$ & $4.23 \mathrm{E}+03$ & $8.45 \mathrm{E}+03$ & $7.35 \mathrm{E}+03$ & $<8.94 \mathrm{E}+02$ \\
\hline Fluoride & $<1.03 \mathrm{E}+02$ & $<1.35 \mathrm{E}+02$ & $<1.06 \mathrm{E}+02$ & $<1.05 \mathrm{E}+02$ & $<1.35 \mathrm{E}+02$ & $<1.13 \mathrm{E}+03$ & $<1.04 \mathrm{E}+03$ & $<1.20 \mathrm{E}+03$ & $<9.64 \mathrm{E}+02$ & $<1.35 \mathrm{E}+03$ & $<1.05 \mathrm{E}+03$ & $<9.24 \mathrm{E}+02$ & $<1.35 \mathrm{E}+03$ & $<8.94 \mathrm{E}+02$ \\
\hline Formate & $1.54 \mathrm{E}+03$ & $1.64 \mathrm{E}+03$ & $1.45 \mathrm{E}+03$ & $2.00 \mathrm{E}+03$ & $1.35 \mathrm{E}+03$ & $1.48 \mathrm{E}+03$ & $1.63 \mathrm{E}+03$ & $1.78 \mathrm{E}+03$ & $1.47 \mathrm{E}+03$ & $1.60 \mathrm{E}+03$ & $1.73 \mathrm{E}+03$ & $1.87 \mathrm{E}+03$ & $1.35 \mathrm{E}+03$ & $1.53 \mathrm{E}+03$ \\
\hline Chloride & $1.23 \mathrm{E}+02$ & $<1.35 \mathrm{E}+02$ & $1.28 \mathrm{E}+02$ & $1.57 \mathrm{E}+02$ & $<1.35 \mathrm{E}+02$ & $<1.13 \mathrm{E}+03$ & $<1.04 \mathrm{E}+03$ & $<1.20 \mathrm{E}+03$ & $<9.64 \mathrm{E}+02$ & $<1.35 \mathrm{E}+03$ & $<1.05 \mathrm{E}+03$ & $<9.24 \mathrm{E}+02$ & $<1.35 \mathrm{E}+03$ & $<8.94 \mathrm{E}+02$ \\
\hline Nitrite & $7.21 \mathrm{E}+04$ & $7.95 \mathrm{E}+04$ & $6.72 \mathrm{E}+04$ & $9.07 \mathrm{E}+04$ & $6.32 \mathrm{E}+04$ & $7.58 \mathrm{E}+04$ & $7.02 \mathrm{E}+04$ & $7.05 E+04$ & $7.07 \mathrm{E}+04$ & $8.08 \mathrm{E}+04$ & $6.97 \mathrm{E}+04$ & $6.95 \mathrm{E}+04$ & $6.32 \mathrm{E}+04$ & $7.01 \mathrm{E}+04$ \\
\hline Bromide & $<1.03 \mathrm{E}+03$ & $<1.35 \mathrm{E}+03$ & $<1.06 \mathrm{E}+03$ & $<1.05 \mathrm{E}+03$ & $<1.35 \mathrm{E}+03$ & $<1.13 \mathrm{E}+03$ & $<1.04 \mathrm{E}+03$ & $<1.20 \mathrm{E}+03$ & $<9.64 \mathrm{E}+02$ & $<1.35 \mathrm{E}+03$ & $<1.05 \mathrm{E}+03$ & $<9.24 \mathrm{E}+02$ & $<1.35 \mathrm{E}+03$ & $<8.94 \mathrm{E}+02$ \\
\hline Nitrate & $5.75 \mathrm{E}+04$ & $6.48 \mathrm{E}+04$ & $5.47 \mathrm{E}+04$ & $7.20 \mathrm{E}+04$ & $5.30 \mathrm{E}+04$ & $5.47 \mathrm{E}+04$ & $5.50 \mathrm{E}+04$ & $5.50 \mathrm{E}+04$ & $5.52 \mathrm{E}+04$ & $6.29 \mathrm{E}+04$ & $5.43 \mathrm{E}+04$ & $5.44 \mathrm{E}+04$ & $5.27 \mathrm{E}+04$ & $5.47 \mathrm{E}+04$ \\
\hline Phosphate & $2.88 \mathrm{E}+02$ & $3.79 \mathrm{E}+02$ & $2.98 \mathrm{E}+02$ & $3.78 \mathrm{E}+02$ & $2.97 \mathrm{E}+02$ & $3.04 \mathrm{E}+02$ & $2.91 \mathrm{E}+02$ & $2.89 \mathrm{E}+02$ & $2.89 \mathrm{E}+02$ & $3.38 \mathrm{E}+02$ & $2.84 \mathrm{E}+02$ & $2.77 \mathrm{E}+02$ & $2.70 \mathrm{E}+02$ & $2.86 \mathrm{E}+02$ \\
\hline Sulfate & $1.90 \mathrm{E}+03$ & $1.66 \mathrm{E}+03$ & $1.88 \mathrm{E}+03$ & $2.50 \mathrm{E}+03$ & $1.35 \mathrm{E}+03$ & $2.07 \mathrm{E}+03$ & $1.93 \mathrm{E}+03$ & $2.03 \mathrm{E}+03$ & $2.03 \mathrm{E}+03$ & $1.65 \mathrm{E}+03$ & $2.00 \mathrm{E}+03$ & $1.99 \mathrm{E}+03$ & $1.49 \mathrm{E}+03$ & $1.99 \mathrm{E}+03$ \\
\hline Oxalate & $2.37 \mathrm{E}+02$ & $<1.35 \mathrm{E}+02$ & $1.91 \mathrm{E}+02$ & $1.78 \mathrm{E}+02$ & $1.49 \mathrm{E}+02$ & $2.59 \mathrm{E}+02$ & $3.33 \mathrm{E}+02$ & $3.73 \mathrm{E}+02$ & $2.51 \mathrm{E}+02$ & $<1.35 \mathrm{E}+02$ & $3.58 \mathrm{E}+02$ & $3.51 \mathrm{E}+02$ & $1.49 \mathrm{E}+02$ & $2.50 \mathrm{E}+02$ \\
\hline \multicolumn{15}{|c|}{ TIC/TOC (mg C/L) } \\
\hline Total Carbon & $4.68 \mathrm{E}+03$ & $5.91 \mathrm{E}+03$ & $7.25 \mathrm{E}+03$ & $1.03 \mathrm{E}+04$ & $7.42 \mathrm{E}+03$ & -- & -- & -- & -- & -- & -- & -- & -- & -- \\
\hline Inorganic Carbon & $4.22 \mathrm{E}+03$ & $5.52 \mathrm{E}+03$ & $4.22 \mathrm{E}+03$ & $5.54 \mathrm{E}+03$ & $4.63 \mathrm{E}+03$ & -- & -- & -- & -- & -- & -- & -- & -- & -- \\
\hline Organic Carbon & $4.62 \mathrm{E}+02$ & $3.88 \mathrm{E}+02$ & $1.97 \mathrm{E}+03$ & $4.74 \mathrm{E}+03$ & $2.78 \mathrm{E}+03$ & -- & -- & -- & -- & -- & -- & -- & -- & -- \\
\hline \multicolumn{15}{|c|}{ Titration (M) } \\
\hline Total Base & $3.51 \mathrm{E}+00$ & $3.62 \mathrm{E}+00$ & $3.49 \mathrm{E}+00$ & $4.52 \mathrm{E}+00$ & $3.15 \mathrm{E}+00$ & -- & -- & -- & -- & -- & -- & -- & -- & -- \\
\hline Free Hydroxide & $2.50 \mathrm{E}+00$ & $2.37 \mathrm{E}+00$ & $2.39 \mathrm{E}+00$ & $3.19 \mathrm{E}+00$ & $2.05 \mathrm{E}+00$ & -- & -- & -- & -- & -- & -- & -- & -- & -- \\
\hline Other Base* & $3.91 \mathrm{E}-01$ & $7.30 \mathrm{E}-01$ & $3.61 \mathrm{E}-01$ & $5.35 \mathrm{E}-01$ & $5.54 \mathrm{E}-01$ & -- & -- & -- & -- & -- & -- & -- & -- & -- \\
\hline
\end{tabular}

* Other Base excluding carbonate 
Table A-3. Analysis of water dilutions for sludge contact testing (contd.)

\begin{tabular}{|c|c|c|c|c|c|c|c|c|c|c|c|c|c|c|}
\hline hold time (days) & 21 & 21 & 21 & 35 & Standard 1 & 35 & 35 & Standard 2 & 35 & 35 & 35 & 35 & 56 & 56 \\
\hline glycolate $(\mathrm{g} / \mathrm{L})$ & 0 & 5 & 10 & 0 & 0 & 5 & 10 & 10 & 0.2 & 0 & 5 & 10 & 0 & 10 \\
\hline $\mathrm{DF}(\mathrm{mL} / \mathrm{mL})$ & 9.68 & 10.97 & 10.71 & 13.50 & 13.52 & 9.85 & 9.53 & 13.51 & 9.70 & 9.47 & 8.47 & 9.46 & 10.92 & 8.57 \\
\hline LIMS number & 300303367 & 300303368 & 300303369 & 300303415 & 300303416 & 300303417 & 300303418 & 300303419 & 300303420 & 300303421 & 300303422 & 300303423 & 300303382 & 300303384 \\
\hline \multicolumn{15}{|c|}{ IC Anions (mg/L) } \\
\hline Glycolate & -- & -- & -- & $<1.35 \mathrm{E}+03$ & $<1.35 \mathrm{E}+03$ & $<3.79 \mathrm{E}+03$ & $<8.38 \mathrm{E}+03$ & $7.67 \mathrm{E}+03$ & $<9.70 \mathrm{E}+02$ & $<9.47 \mathrm{E}+02$ & $<3.86 \mathrm{E}+03$ & $<8.16 \mathrm{E}+03$ & $<5.46 \mathrm{E}+02$ & $6.59 \mathrm{E}+03$ \\
\hline Fluoride & -- & -- & -- & -- & -- & -- & -- & -- & -- & -- & -- & -- & $<5.46 \mathrm{E}+02$ & $<4.29 \mathrm{E}+02$ \\
\hline Formate & -- & -- & -- & -- & -- & -- & -- & -- & -- & -- & -- & -- & $1.18 \mathrm{E}+03$ & $3.80 \mathrm{E}+03$ \\
\hline Chloride & -- & -- & -- & -- & -- & -- & -- & -- & -- & -- & -- & -- & $<5.46 \mathrm{E}+02$ & $<4.29 \mathrm{E}+02$ \\
\hline Nitrite & -- & -- & -- & -- & -- & -- & -- & -- & -- & -- & -- & -- & $7.30 \mathrm{E}+04$ & $7.17 \mathrm{E}+04$ \\
\hline Bromide & -- & -- & -- & -- & -- & -- & -- & -- & -- & -- & -- & -- & $<5.46 \mathrm{E}+03$ & $<4.29 \mathrm{E}+03$ \\
\hline Nitrate & -- & -- & -- & -- & -- & -- & -- & -- & -- & -- & -- & -- & $5.42 \mathrm{E}+04$ & $5.45 \mathrm{E}+04$ \\
\hline Phosphate & -- & -- & -- & -- & -- & -- & -- & -- & -- & -- & -- & -- & $2.95 \mathrm{E}+02$ & $2.83 \mathrm{E}+02$ \\
\hline Sulfate & -- & -- & -- & -- & -- & -- & -- & -- & -- & -- & -- & -- & $1.99 \mathrm{E}+03$ & $2.01 \mathrm{E}+03$ \\
\hline Oxalate & -- & -- & -- & -- & -- & -- & -- & -- & -- & -- & -- & -- & $4.04 \mathrm{E}+02$ & $1.48 \mathrm{E}+03$ \\
\hline \multicolumn{15}{|c|}{ TIC/TOC (mg C/L) } \\
\hline Total Carbon & -- & -- & -- & $4.79 \mathrm{E}+02$ & $6.37 \mathrm{E}+03$ & $1.70 \mathrm{E}+03$ & $3.29 \mathrm{E}+03$ & $7.90 \mathrm{E}+03$ & $4.69 \mathrm{E}+02$ & $4.11 \mathrm{E}+02$ & $1.72 \mathrm{E}+03$ & $3.26 \mathrm{E}+03$ & $5.52 \mathrm{E}+03$ & $8.29 \mathrm{E}+03$ \\
\hline Inorganic Carbon & -- & -- & -- & $1.97 \mathrm{E}+02$ & $5.95 \mathrm{E}+03$ & $1.41 \mathrm{E}+02$ & $1.44 \mathrm{E}+02$ & $4.96 \mathrm{E}+03$ & $1.20 \mathrm{E}+02$ & $1.57 \mathrm{E}+02$ & $1.62 \mathrm{E}+02$ & $1.67 \mathrm{E}+02$ & $4.94 \mathrm{E}+03$ & $5.01 \mathrm{E}+03$ \\
\hline Organic Carbon & -- & -- & -- & $2.82 \mathrm{E}+02$ & $4.22 \mathrm{E}+02$ & $1.57 \mathrm{E}+03$ & $3.14 \mathrm{E}+03$ & $2.94 \mathrm{E}+03$ & $3.48 \mathrm{E}+02$ & $2.54 \mathrm{E}+02$ & $1.56 \mathrm{E}+03$ & $3.09 \mathrm{E}+03$ & $5.90 \mathrm{E}+02$ & $3.27 \mathrm{E}+03$ \\
\hline \multicolumn{15}{|c|}{ Titration (M) } \\
\hline Total Base & -- & -- & -- & -- & -- & -- & -- & -- & -- & -- & -- & -- & $2.95 \mathrm{E}+00$ & $2.80 \mathrm{E}+00$ \\
\hline Free Hydroxide & -- & -- & -- & -- & -- & -- & -- & -- & -- & -- & -- & -- & $2.51 \mathrm{E}+00$ & $2.46 \mathrm{E}+00$ \\
\hline Other Base* & -- & -- & -- & -- & -- & -- & -- & -- & -- & -- & -- & -- & $<5.46 \mathrm{E}-01$ & $<4.29 \mathrm{E}-01$ \\
\hline
\end{tabular}

* Other Base excluding carbonate 
Table A-4. Analysis results for acid dilutions of evaporator scale contact tests

\begin{tabular}{|c|c|c|c|c|c|c|c|c|}
\hline hold time (days) & 0 & 0 & 19 & 19 & 20 & 19 & 20 & 20 \\
\hline glycolate $(\mathrm{g} / \mathrm{L})$ & 0 & 10 & 0 & 0 & 0 & 10 & 10 & 10 \\
\hline $\mathrm{DF}(\mathrm{mL} / \mathrm{mL})$ & 18.73 & 18.31 & 10.96 & 10.59 & 10.91 & 11.07 & 10.83 & 11.29 \\
\hline \multirow[t]{2}{*}{ LIMS numbers } & 300304639 & 300304641 & 300304643 & 300304645 & 300304647 & 300304644 & 300304646 & 300304648 \\
\hline & 300304649 & 300304651 & 300304653 & 300304655 & 300304657 & 300304654 & 300304656 & 300304658 \\
\hline \multicolumn{9}{|c|}{ ICP-ES (mg/L) } \\
\hline $\mathrm{Ag}$ & $<2.10 \mathrm{E}+00$ & $<2.05 \mathrm{E}+00$ & $<1.23 \mathrm{E}+00$ & $<1.19 \mathrm{E}+00$ & $<1.22 \mathrm{E}+00$ & $<1.24 \mathrm{E}+00$ & $<1.21 \mathrm{E}+00$ & $<1.26 \mathrm{E}+00$ \\
\hline $\mathrm{Al}$ & $1.33 \mathrm{E}+03$ & $1.26 \mathrm{E}+03$ & $1.24 \mathrm{E}+03$ & $1.39 \mathrm{E}+03$ & $1.24 \mathrm{E}+03$ & $1.33 \mathrm{E}+03$ & $1.52 \mathrm{E}+03$ & $1.20 \mathrm{E}+03$ \\
\hline B & $1.16 \mathrm{E}+02$ & $1.12 \mathrm{E}+02$ & $1.15 \mathrm{E}+02$ & $1.22 \mathrm{E}+02$ & $1.17 \mathrm{E}+02$ & $1.25 \mathrm{E}+02$ & $1.30 \mathrm{E}+02$ & $1.15 \mathrm{E}+02$ \\
\hline $\mathrm{Ba}$ & $<9.93 \mathrm{E}-01$ & $<9.70 \mathrm{E}-01$ & $<5.81 \mathrm{E}-01$ & $<5.61 \mathrm{E}-01$ & $<5.78 \mathrm{E}-01$ & $<5.87 \mathrm{E}-01$ & $<5.74 \mathrm{E}-01$ & $<5.98 \mathrm{E}-01$ \\
\hline $\mathrm{Be}$ & $<2.25 \mathrm{E}-01$ & $<2.20 \mathrm{E}-01$ & $<1.31 \mathrm{E}-01$ & $<1.27 \mathrm{E}-01$ & $<1.31 \mathrm{E}-01$ & $<1.33 \mathrm{E}-01$ & $<1.30 \mathrm{E}-01$ & $<1.35 \mathrm{E}-01$ \\
\hline $\mathrm{Ca}$ & $9.78 \mathrm{E}+00$ & $1.24 \mathrm{E}+01$ & $1.83 \mathrm{E}+01$ & $1.15 \mathrm{E}+01$ & $1.25 \mathrm{E}+01$ & $1.93 \mathrm{E}+01$ & $1.65 \mathrm{E}+01$ & $1.58 \mathrm{E}+01$ \\
\hline $\mathrm{Cd}$ & $<2.68 \mathrm{E}+00$ & $<2.62 \mathrm{E}+00$ & $<1.57 \mathrm{E}+00$ & $<1.51 \mathrm{E}+00$ & $<1.56 \mathrm{E}+00$ & $<1.58 \mathrm{E}+00$ & $<1.55 \mathrm{E}+00$ & $<1.61 \mathrm{E}+00$ \\
\hline $\mathrm{Ce}$ & $<1.53 \mathrm{E}+01$ & $<1.50 \mathrm{E}+01$ & $<8.97 \mathrm{E}+00$ & $<8.67 \mathrm{E}+00$ & $<8.93 \mathrm{E}+00$ & $<9.07 \mathrm{E}+00$ & $<8.87 \mathrm{E}+00$ & $<9.25 \mathrm{E}+00$ \\
\hline Co & $<3.47 \mathrm{E}+00$ & $<3.39 \mathrm{E}+00$ & $<2.03 \mathrm{E}+00$ & $<1.96 \mathrm{E}+00$ & $<2.02 \mathrm{E}+00$ & $<2.05 \mathrm{E}+00$ & $<2.00 \mathrm{E}+00$ & $<2.09 \mathrm{E}+00$ \\
\hline $\mathrm{Cr}$ & $4.78 \mathrm{E}+01$ & $4.78 \mathrm{E}+01$ & $4.66 \mathrm{E}+01$ & $4.45 \mathrm{E}+01$ & $4.87 \mathrm{E}+01$ & $5.14 \mathrm{E}+01$ & $5.09 \mathrm{E}+01$ & $4.88 \mathrm{E}+01$ \\
\hline $\mathrm{Cu}$ & $<1.84 \mathrm{E}+00$ & $<1.79 \mathrm{E}+00$ & $<1.07 \mathrm{E}+00$ & $<1.04 \mathrm{E}+00$ & $<1.07 \mathrm{E}+00$ & $<1.09 \mathrm{E}+00$ & $<1.34 \mathrm{E}+00$ & $<1.11 \mathrm{E}+00$ \\
\hline $\mathrm{Fe}$ & $6.71 \mathrm{E}+00$ & $3.17 \mathrm{E}+00$ & $<1.35 \mathrm{E}+00$ & $<1.30 \mathrm{E}+00$ & $1.57 \mathrm{E}+00$ & $4.71 \mathrm{E}+00$ & $<1.33 \mathrm{E}+00$ & $1.39 \mathrm{E}+00$ \\
\hline Gd & $<8.88 \mathrm{E}+00$ & $<8.68 \mathrm{E}+00$ & $<5.19 \mathrm{E}+00$ & $<5.02 \mathrm{E}+00$ & $<5.17 \mathrm{E}+00$ & $<5.25 \mathrm{E}+00$ & $<5.13 \mathrm{E}+00$ & $<5.35 \mathrm{E}+00$ \\
\hline K & $2.74 \mathrm{E}+02$ & $2.71 \mathrm{E}+02$ & $3.00 \mathrm{E}+02$ & $3.59 \mathrm{E}+02$ & $3.57 \mathrm{E}+02$ & $3.64 \mathrm{E}+02$ & $4.33 \mathrm{E}+02$ & $3.61 \mathrm{E}+02$ \\
\hline $\mathrm{La}$ & $<2.36 \mathrm{E}+00$ & $<2.31 \mathrm{E}+00$ & $<1.38 \mathrm{E}+00$ & $<1.33 \mathrm{E}+00$ & $<1.37 \mathrm{E}+00$ & $<1.40 \mathrm{E}+00$ & $<1.36 \mathrm{E}+00$ & $<1.42 \mathrm{E}+00$ \\
\hline $\mathrm{Li}$ & $4.55 \mathrm{E}+01$ & $4.36 \mathrm{E}+01$ & $4.38 \mathrm{E}+01$ & $4.62 \mathrm{E}+01$ & $4.48 \mathrm{E}+01$ & $4.66 \mathrm{E}+01$ & $4.89 \mathrm{E}+01$ & $4.35 \mathrm{E}+01$ \\
\hline $\mathrm{Mg}$ & 2.62E-01 & $3.66 \mathrm{E}-01$ & $3.62 \mathrm{E}-01$ & & 3.82E-01 & 7.81E-01 & 4.93E-01 & 4.29E-01 \\
\hline $\mathrm{Mn}$ & $<1.44 \mathrm{E}+00$ & $<1.41 \mathrm{E}+00$ & $<8.44 \mathrm{E}-01$ & $<8.16 \mathrm{E}-01$ & $<8.40 \mathrm{E}-01$ & $<8.53 \mathrm{E}-01$ & $<8.34 \mathrm{E}-01$ & 3.69E-01 \\
\hline Mo & $<1.84 \mathrm{E}+01$ & $<1.80 \mathrm{E}+01$ & $<1.08 \mathrm{E}+01$ & $<1.04 \mathrm{E}+01$ & $<1.07 \mathrm{E}+01$ & $<1.09 \mathrm{E}+01$ & $<1.06 \mathrm{E}+01$ & $<1.11 \mathrm{E}+01$ \\
\hline $\mathrm{Na}$ & $1.33 \mathrm{E}+05$ & $1.30 \mathrm{E}+05$ & $1.27 \mathrm{E}+05$ & $1.35 \mathrm{E}+05$ & $1.29 \mathrm{E}+05$ & $1.41 \mathrm{E}+05$ & $1.46 \mathrm{E}+05$ & $1.30 \mathrm{E}+05$ \\
\hline $\mathrm{Ni}$ & $<3.88 \mathrm{E}+00$ & $<3.79 \mathrm{E}+00$ & $<2.27 \mathrm{E}+00$ & $<2.19 \mathrm{E}+00$ & $<2.26 \mathrm{E}+00$ & $<2.29 \mathrm{E}+00$ & $<2.24 \mathrm{E}+00$ & $<2.34 \mathrm{E}+00$ \\
\hline $\mathrm{P}$ & $1.22 \mathrm{E}+02$ & $1.13 \mathrm{E}+02$ & $1.29 \mathrm{E}+02$ & $1.39 \mathrm{E}+02$ & $1.39 \mathrm{E}+02$ & $1.49 \mathrm{E}+02$ & $1.51 \mathrm{E}+02$ & $1.24 \mathrm{E}+02$ \\
\hline $\mathrm{Pb}$ & $<8.64 \mathrm{E}+01$ & $<8.44 \mathrm{E}+01$ & $<5.05 \mathrm{E}+01$ & $<4.88 \mathrm{E}+01$ & $<5.03 \mathrm{E}+01$ & $<5.10 \mathrm{E}+01$ & $<4.99 \mathrm{E}+01$ & $<5.20 \mathrm{E}+01$ \\
\hline $\mathrm{S}$ & $<1.12 \mathrm{E}+03$ & $<1.10 \mathrm{E}+03$ & $1.16 \mathrm{E}+03$ & $1.26 \mathrm{E}+03$ & $9.51 \mathrm{E}+02$ & $8.04 \mathrm{E}+02$ & $1.07 \mathrm{E}+03$ & $1.29 \mathrm{E}+03$ \\
\hline $\mathrm{Sb}$ & $<6.46 \mathrm{E}+01$ & $<6.32 \mathrm{E}+01$ & $<3.78 \mathrm{E}+01$ & $<3.65 \mathrm{E}+01$ & $<3.76 \mathrm{E}+01$ & $<3.82 \mathrm{E}+01$ & $<3.74 \mathrm{E}+01$ & $<3.89 \mathrm{E}+01$ \\
\hline $\mathrm{Si}$ & $4.08 \mathrm{E}+01$ & $4.08 \mathrm{E}+01$ & $3.40 \mathrm{E}+01$ & $3.48 \mathrm{E}+01$ & $3.50 \mathrm{E}+01$ & $3.44 \mathrm{E}+01$ & $3.54 \mathrm{E}+01$ & $3.38 \mathrm{E}+01$ \\
\hline $\mathrm{Sn}$ & $<6.78 \mathrm{E}+01$ & $<6.63 \mathrm{E}+01$ & $<3.97 \mathrm{E}+01$ & $<3.83 \mathrm{E}+01$ & $<3.95 \mathrm{E}+01$ & $<4.01 \mathrm{E}+01$ & $<3.92 \mathrm{E}+01$ & $<4.09 \mathrm{E}+01$ \\
\hline $\mathrm{Sr}$ & $<9.37 \mathrm{E}-01$ & $<9.15 \mathrm{E}-01$ & $<5.48 \mathrm{E}-01$ & $<5.30 \mathrm{E}-01$ & $<5.45 \mathrm{E}-01$ & $<5.54 \mathrm{E}-01$ & $<5.41 \mathrm{E}-01$ & $<5.64 \mathrm{E}-01$ \\
\hline Th & $<9.59 \mathrm{E}+00$ & $<9.37 \mathrm{E}+00$ & $<5.61 \mathrm{E}+00$ & $<5.42 \mathrm{E}+00$ & $<5.59 \mathrm{E}+00$ & $<5.67 \mathrm{E}+00$ & $<5.54 \mathrm{E}+00$ & $<5.78 \mathrm{E}+00$ \\
\hline $\mathrm{Ti}$ & $<1.09 \mathrm{E}+00$ & $<1.06 \mathrm{E}+00$ & $<6.35 \mathrm{E}-01$ & $<6.14 \mathrm{E}-01$ & $<6.33 \mathrm{E}-01$ & $<6.42 \mathrm{E}-01$ & $<6.28 \mathrm{E}-01$ & $<6.55 \mathrm{E}-01$ \\
\hline $\mathrm{U}$ & $<5.28 \mathrm{E}+01$ & $<5.16 \mathrm{E}+01$ & $<3.09 \mathrm{E}+01$ & $<2.99 \mathrm{E}+01$ & $<3.08 \mathrm{E}+01$ & $<3.12 \mathrm{E}+01$ & $<3.05 \mathrm{E}+01$ & $<3.18 \mathrm{E}+01$ \\
\hline V & $<1.18 \mathrm{E}+00$ & $<1.15 \mathrm{E}+00$ & $<6.90 \mathrm{E}-01$ & $<6.67 \mathrm{E}-01$ & $<6.87 \mathrm{E}-01$ & $<6.98 \mathrm{E}-01$ & $<6.82 \mathrm{E}-01$ & $<7.11 \mathrm{E}-01$ \\
\hline $\mathrm{Zn}$ & $5.23 \mathrm{E}+00$ & $5.05 \mathrm{E}+00$ & $5.35 \mathrm{E}+00$ & $5.48 \mathrm{E}+00$ & $5.43 \mathrm{E}+00$ & $5.49 \mathrm{E}+00$ & $5.57 \mathrm{E}+00$ & $5.06 \mathrm{E}+00$ \\
\hline $\mathrm{Zr}$ & $<9.18 \mathrm{E}-01$ & $<8.97 \mathrm{E}-01$ & $<5.37 \mathrm{E}-01$ & $<5.19 \mathrm{E}-01$ & $<5.35 \mathrm{E}-01$ & $<5.43 \mathrm{E}-01$ & $<5.31 \mathrm{E}-01$ & $<5.53 \mathrm{E}-01$ \\
\hline \multicolumn{9}{|c|}{ CVAA Hg (mg/L) } \\
\hline $\mathrm{Hg}$ & $2.19 \mathrm{E}+02$ & $1.52 \mathrm{E}+02$ & $3.57 \mathrm{E}+02$ & $3.30 \mathrm{E}+02$ & $3.53 \mathrm{E}+02$ & $2.31 \mathrm{E}+02$ & $2.70 \mathrm{E}+02$ & $2.43 \mathrm{E}+02$ \\
\hline \multicolumn{9}{|c|}{ PuTTA (dpm/mL) } \\
\hline $\mathrm{Pu}-238$ & $4.05 \mathrm{E}+03$ & $7.27 \mathrm{E}+02$ & $3.80 \mathrm{E}+02$ & $5.55 \mathrm{E}+02$ & $3.77 \mathrm{E}+02$ & $3.79 \mathrm{E}+02$ & $3.35 \mathrm{E}+02$ & $<1.39 \mathrm{E}+02^{\mathrm{a}}$ \\
\hline $\mathrm{Pu}-239 / 240$ & $4.76 \mathrm{E}+02$ & $<1.25 \mathrm{E}+02^{\mathrm{a}}$ & $<7.29 \mathrm{E}+01^{\mathrm{a}}$ & $<6.77 \mathrm{E}+01^{\mathrm{a}}$ & $<1.31 \mathrm{E}+02^{\mathrm{a}}$ & $<6.06 \mathrm{E}+01^{\mathrm{a}}$ & $<3.68 \mathrm{E}+01^{\mathrm{a}}$ & $<6.12 \mathrm{E}+01$ \\
\hline
\end{tabular}

\footnotetext{
a some $\mathrm{Pu}-238$ measurements are reported as "upper limit" values due to potential interferences.
} 
Table A-5. ICP-MS results for acid dilutions of evaporator scale contact tests

\begin{tabular}{|c|c|c|c|c|c|c|c|c|}
\hline hold time (days) & 0 & 0 & 19 & 19 & 20 & 19 & 20 & 20 \\
\hline glycolate $(\mathrm{g} / \mathrm{L})$ & 0 & 10 & 0 & 0 & 0 & 10 & 10 & 10 \\
\hline $\mathrm{DF}(\mathrm{mL} / \mathrm{mL})$ & 18.73 & 18.31 & 10.96 & 10.59 & 10.91 & 11.07 & 10.83 & 11.29 \\
\hline LIMS numbers & 300304639 & 300304641 & 300304643 & 300304645 & 300304647 & 300304644 & 300304646 & 300304648 \\
\hline $\operatorname{mass}(\mathrm{m} / \mathrm{z})=59$ & $<7.49 \mathrm{E}-02$ & $<7.32 \mathrm{E}-02$ & $<4.38 \mathrm{E}-02$ & $<4.24 \mathrm{E}-02$ & $<4.36 \mathrm{E}-02$ & $<4.43 \mathrm{E}-02$ & $<4.33 \mathrm{E}-02$ & $<4.52 \mathrm{E}-02$ \\
\hline 82 & $<1.95 \mathrm{E}+00$ & $<1.90 \mathrm{E}+00$ & $<1.14 \mathrm{E}+00$ & $<1.10 \mathrm{E}+00$ & $<1.13 \mathrm{E}+00$ & $<1.15 \mathrm{E}+00$ & $<1.13 \mathrm{E}+00$ & $<1.17 \mathrm{E}+00$ \\
\hline 84 & $<1.12 \mathrm{E}+00$ & $<1.10 \mathrm{E}+00$ & $<6.57 \mathrm{E}-01$ & $<6.36 \mathrm{E}-01$ & $<6.55 \mathrm{E}-01$ & $<6.64 \mathrm{E}-01$ & $<6.50 \mathrm{E}-01$ & $<6.77 \mathrm{E}-01$ \\
\hline 85 & $2.57 \mathrm{E}-01$ & $2.59 \mathrm{E}-01$ & $2.75 \mathrm{E}-01$ & $2.56 \mathrm{E}-01$ & 2.34E-01 & $2.74 \mathrm{E}-01$ & $2.73 \mathrm{E}-01$ & $2.60 \mathrm{E}-01$ \\
\hline 86 & $<9.93 \mathrm{E}-01$ & $<9.70 \mathrm{E}-01$ & $<5.81 \mathrm{E}-01$ & $<5.61 \mathrm{E}-01$ & $<5.78 \mathrm{E}-01$ & $<5.87 \mathrm{E}-01$ & $<5.74 \mathrm{E}-01$ & $<5.98 \mathrm{E}-01$ \\
\hline 87 & $3.70 \mathrm{E}-01$ & 4.49E-01 & 4.22E-01 & 4.39E-01 & 4.67E-01 & 4.87E-01 & $4.68 \mathrm{E}-01$ & 4.64E-01 \\
\hline 88 & $<7.49 \mathrm{E}-02$ & $<7.32 \mathrm{E}-02$ & $8.38 \mathrm{E}-02$ & $<4.24 \mathrm{E}-02$ & $6.31 \mathrm{E}-02$ & $6.88 \mathrm{E}-02$ & $6.47 \mathrm{E}-02$ & $7.40 \mathrm{E}-02$ \\
\hline 89 & $<1.12 \mathrm{E}-01$ & $<1.10 \mathrm{E}-01$ & $<6.57 \mathrm{E}-02$ & $<6.36 \mathrm{E}-02$ & $<6.55 \mathrm{E}-02$ & $<6.64 \mathrm{E}-02$ & $<6.50 \mathrm{E}-02$ & $<6.77 \mathrm{E}-02$ \\
\hline 90 & $<1.87 \mathrm{E}-01$ & $<1.83 \mathrm{E}-01$ & $<1.10 \mathrm{E}-01$ & $<1.06 \mathrm{E}-01$ & $<1.09 \mathrm{E}-01$ & $<1.11 \mathrm{E}-01$ & $<1.08 \mathrm{E}-01$ & $<1.13 \mathrm{E}-01$ \\
\hline 91 & $<5.62 \mathrm{E}-02$ & $<5.49 \mathrm{E}-02$ & $<3.29 \mathrm{E}-02$ & $<3.18 \mathrm{E}-02$ & $<3.27 \mathrm{E}-02$ & $<3.32 \mathrm{E}-02$ & $<3.25 \mathrm{E}-02$ & $<3.39 \mathrm{E}-02$ \\
\hline 92 & $3.08 \mathrm{E}-01$ & 3.31E-01 & $3.16 \mathrm{E}-01$ & $3.13 \mathrm{E}-01$ & 2.93E-01 & $3.57 \mathrm{E}-01$ & $3.66 \mathrm{E}-01$ & $3.28 \mathrm{E}-01$ \\
\hline 93 & $<5.62 \mathrm{E}-02$ & $<5.49 \mathrm{E}-02$ & $<3.29 \mathrm{E}-02$ & $<3.18 \mathrm{E}-02$ & $<3.27 \mathrm{E}-02$ & $<3.32 \mathrm{E}-02$ & $<3.25 \mathrm{E}-02$ & $<3.39 \mathrm{E}-02$ \\
\hline 94 & $2.48 \mathrm{E}-01$ & $2.21 \mathrm{E}-01$ & 2.34E-01 & $2.16 \mathrm{E}-01$ & 2.19E-01 & 2.31E-01 & $2.58 \mathrm{E}-01$ & $2.57 \mathrm{E}-01$ \\
\hline 95 & $1.27 \mathrm{E}+00$ & $1.25 \mathrm{E}+00$ & $1.34 \mathrm{E}+00$ & $1.21 \mathrm{E}+00$ & $1.43 \mathrm{E}+00$ & $1.39 \mathrm{E}+00$ & $1.34 \mathrm{E}+00$ & $1.39 \mathrm{E}+00$ \\
\hline 96 & $4.50 \mathrm{E}-01$ & $3.86 \mathrm{E}-01$ & 4.24E-01 & 4.41E-01 & 4.59E-01 & 4.77E-01 & 4.82E-01 & $4.65 \mathrm{E}-01$ \\
\hline 97 & $1.08 \mathrm{E}+00$ & $1.08 \mathrm{E}+00$ & $1.05 \mathrm{E}+00$ & $8 \mathrm{E}+00$ & $1.13 \mathrm{E}+00$ & $1.26 \mathrm{E}+00$ & $1.27 \mathrm{E}+00$ & $1.14 \mathrm{E}+00$ \\
\hline 98 & $1.50 \mathrm{E}+00$ & $1.33 \mathrm{E}+00$ & $1.51 \mathrm{E}+00$ & $1.37 \mathrm{E}+00$ & $1.42 \mathrm{E}+00$ & $1.55 \mathrm{E}+00$ & $1.43 \mathrm{E}+00$ & $1.56 \mathrm{E}+00$ \\
\hline 99 & $1.09 \mathrm{E}+00$ & $1.12 \mathrm{E}+00$ & $1.06 \mathrm{E}+00$ & 8.80E-01 & $1.05 \mathrm{E}+00$ & $9.30 \mathrm{E}-01$ & 8.22E-01 & $8.50 \mathrm{E}-01$ \\
\hline 100 & $1.16 \mathrm{E}+00$ & $1.25 \mathrm{E}+00$ & $1.14 \mathrm{E}+00$ & $1.16 \mathrm{E}+00$ & $1.14 \mathrm{E}+00$ & $1.32 \mathrm{E}+00$ & $1.35 \mathrm{E}+00$ & $1.21 \mathrm{E}+00$ \\
\hline 101 & 7.70E-01 & $1.02 \mathrm{E}+00$ & 8.14E-01 & $8.26 \mathrm{E}-01$ & 8.58E-01 & $1.38 \mathrm{E}+00$ & $1.21 \mathrm{E}+00$ & $1.10 \mathrm{E}+00$ \\
\hline 102 & $1 \mathrm{E}-01$ & E-01 & & & & $1.08 \mathrm{E}+00$ & $1.16 \mathrm{E}+00$ & $1.05 \mathrm{E}+00$ \\
\hline 103 & $2.81 \mathrm{E}-01$ & 7.67E-01 & $2.63 \mathrm{E}-01$ & 2.94E-01 & $3.26 \mathrm{E}-01$ & 8.39E-01 & $8.15 \mathrm{E}-01$ & 7.07E-01 \\
\hline 104 & 4.54E-01 & $5.81 \mathrm{E}-01$ & 4.47E-01 & $3.73 \mathrm{E}-01$ & $3.83 \mathrm{E}-01$ & $5.53 \mathrm{E}-01$ & $5.87 \mathrm{E}-01$ & $5.06 \mathrm{E}-01$ \\
\hline 105 & $<1.12 \mathrm{E}-01$ & $<1.10 \mathrm{E}-01$ & $<6.57 \mathrm{E}-02$ & $<6.36 \mathrm{E}-02$ & $<6.55 \mathrm{E}-02$ & $<8.19$ E-02 & $<7.39 \mathrm{E}-02$ & $<7.35 \mathrm{E}-02$ \\
\hline 106 & $1.23 \mathrm{E}-01$ & $9.72 \mathrm{E}-02$ & 8.89E-02 & $7.66 \mathrm{E}-02$ & $8.15 \mathrm{E}-02$ & 7.42E-02 & 8.21E-02 & $6.59 \mathrm{E}-02$ \\
\hline 107 & $<4.87 \mathrm{E}-01$ & $<4.76 \mathrm{E}-01$ & $<2.85 \mathrm{E}-01$ & $<2.75 \mathrm{E}-01$ & $<2.84 \mathrm{E}-01$ & $<2.88 \mathrm{E}-01$ & $<2.82 \mathrm{E}-01$ & $<2.94 \mathrm{E}-01$ \\
\hline 108 & $<1.87 \mathrm{E}-01$ & $<1.83 \mathrm{E}-01$ & $<1.10 \mathrm{E}-01$ & $<1.06 \mathrm{E}-01$ & $<1.09 \mathrm{E}-01$ & $<1.11 \mathrm{E}-01$ & $<1.08 \mathrm{E}-01$ & $<1.13 \mathrm{E}-01$ \\
\hline 109 & 2.04E-01 & $6.81 \mathrm{E}-02$ & 2.90E-02 & $<2.12 \mathrm{E}-02$ & $<2.18 \mathrm{E}-02$ & $<2.21 \mathrm{E}-02$ & $<2.17 \mathrm{E}-02$ & $<2.26 \mathrm{E}-02$ \\
\hline 110 & 4.34E-02 & $<3.66 \mathrm{E}-02$ & 2.93E-02 & $2.17 \mathrm{E}-02$ & 2.61E-02 & $<2.21 \mathrm{E}-02$ & $<2.17 \mathrm{E}-02$ & $2.64 \mathrm{E}-02$ \\
\hline 111 & $<3.75 \mathrm{E}-02$ & $<3.66 \mathrm{E}-02$ & $<2.19 \mathrm{E}-02$ & $<2.12 \mathrm{E}-02$ & 2.19E-02 & $<2.21 \mathrm{E}-02$ & $<2.17 \mathrm{E}-02$ & $<2.26 \mathrm{E}-02$ \\
\hline 112 & $<5.62 \mathrm{E}-02$ & $<5.49 \mathrm{E}-02$ & $<3.29 \mathrm{E}-02$ & $<3.18 \mathrm{E}-02$ & $<3.27 \mathrm{E}-02$ & $<3.32 \mathrm{E}-02$ & $<3.25 \mathrm{E}-02$ & $<3.39 \mathrm{E}-02$ \\
\hline 113 & $<2.27 \mathrm{E}+00$ & $<2.22 \mathrm{E}+00$ & $<1.33 \mathrm{E}+00$ & $<1.28 \mathrm{E}+00$ & $<1.32 \mathrm{E}+00$ & $<1.34 \mathrm{E}+00$ & $<1.31 \mathrm{E}+00$ & $<1.37 \mathrm{E}+00$ \\
\hline 114 & $<1.12 \mathrm{E}-01$ & $<1.10 \mathrm{E}-01$ & $<6.57 \mathrm{E}-02$ & $<6.36 \mathrm{E}-02$ & $<6.55 \mathrm{E}-02$ & $<6.64 \mathrm{E}-02$ & $<6.50 \mathrm{E}-02$ & $<6.77 \mathrm{E}-02$ \\
\hline 116 & $1.01 \mathrm{E}-01$ & $1.14 \mathrm{E}-01$ & $1.10 \mathrm{E}-01$ & $9.63 \mathrm{E}-02$ & $1.11 \mathrm{E}-01$ & $1.04 \mathrm{E}-01$ & $1.26 \mathrm{E}-01$ & $1.09 \mathrm{E}-01$ \\
\hline 117 & $<3.75 \mathrm{E}-02$ & $6.81 \mathrm{E}-02$ & 5.62E-02 & $7.57 \mathrm{E}-02$ & $6.16 \mathrm{E}-02$ & 6.49E-02 & $7.06 \mathrm{E}-02$ & $5.59 \mathrm{E}-02$ \\
\hline 118 & $1.38 \mathrm{E}-01$ & $1.47 \mathrm{E}-01$ & $1.34 \mathrm{E}-01$ & 1.49E-01 & $1.35 \mathrm{E}-01$ & $1.36 \mathrm{E}-01$ & $1.50 \mathrm{E}-01$ & $1.40 \mathrm{E}-01$ \\
\hline 119 & $5.80 \mathrm{E}-02$ & $1.54 \mathrm{E}-01$ & $6.13 \mathrm{E}-02$ & $1.03 \mathrm{E}-01$ & 7.29E-02 & $1.07 \mathrm{E}-01$ & $1.11 \mathrm{E}-01$ & $7.25 \mathrm{E}-02$ \\
\hline 120 & $1.72 \mathrm{E}-01$ & $1.92 \mathrm{E}-01$ & $1.68 \mathrm{E}-01$ & $1.64 \mathrm{E}-01$ & $1.81 \mathrm{E}-01$ & $1.85 \mathrm{E}-01$ & $1.73 \mathrm{E}-01$ & $1.73 \mathrm{E}-01$ \\
\hline 121 & $<3.00 \mathrm{E}-01$ & $<2.93 \mathrm{E}-01$ & $<1.75 \mathrm{E}-01$ & $<1.69 \mathrm{E}-01$ & $<1.75 \mathrm{E}-01$ & $<1.77 \mathrm{E}-01$ & $<1.73 \mathrm{E}-01$ & $<1.81 \mathrm{E}-01$ \\
\hline 122 & $5.55 \mathrm{E}-02$ & $6.43 \mathrm{E}-02$ & $5.88 \mathrm{E}-02$ & 4.87E-02 & $5.51 \mathrm{E}-02$ & $6.69 \mathrm{E}-02$ & $6.18 \mathrm{E}-02$ & $5.05 \mathrm{E}-02$ \\
\hline 123 & $<1.31 \mathrm{E}-01$ & $<1.28 \mathrm{E}-01$ & $<7.67 \mathrm{E}-02$ & $<7.41 \mathrm{E}-02$ & $<7.64 \mathrm{E}-02$ & $<7.75 \mathrm{E}-02$ & $<7.58 \mathrm{E}-02$ & $<7.90 \mathrm{E}-02$ \\
\hline 124 & 7.89E-02 & $7.68 \mathrm{E}-02$ & $9.20 \mathrm{E}-02$ & $9.24 \mathrm{E}-02$ & $8.42 \mathrm{E}-02$ & 8.81E-02 & 5.99E-02 & $6.58 \mathrm{E}-02$ \\
\hline 125 & $<3.75 \mathrm{E}-02$ & $<3.66 \mathrm{E}-02$ & $<2.19 \mathrm{E}-02$ & $<2.12 \mathrm{E}-02$ & $<2.18 \mathrm{E}-02$ & $<2.21 \mathrm{E}-02$ & $<2.17 \mathrm{E}-02$ & $<2.26 \mathrm{E}-02$ \\
\hline
\end{tabular}


Table A-5. ICP-MS results for acid dilutions of evaporator scale contact tests (contd.)

\begin{tabular}{|c|c|c|c|c|c|c|c|c|}
\hline hold time (days) & 0 & 0 & 19 & 19 & 20 & 19 & 20 & 20 \\
\hline glycolate $(\mathrm{g} / \mathrm{L})$ & 0 & 10 & 0 & 0 & 0 & 10 & 10 & 0 \\
\hline $\mathrm{DF}(\mathrm{mL} / \mathrm{mL})$ & 18.73 & 18.31 & 10.96 & 10.59 & 10.91 & 11.07 & 10.83 & 11.29 \\
\hline LIMS numbers & 300304639 & 300304641 & 300304643 & 300304645 & 300304647 & 300304644 & 300304646 & 003046 \\
\hline $\operatorname{mass}(\mathrm{m} / \mathrm{z})=126$ & $<1.31 \mathrm{E}-01$ & $1.45 \mathrm{E}-01$ & $1.00 \mathrm{E}-01$ & $7.98 \mathrm{E}-02$ & $9.69 \mathrm{E}-02$ & $8.11 \mathrm{E}-02$ & $9.85 \mathrm{E}-02$ & $9.88 \mathrm{E}-02$ \\
\hline 128 & $<3.18 \mathrm{E}-01$ & $<3.11 \mathrm{E}-01$ & $<1.86 \mathrm{E}-01$ & $<1.80 \mathrm{E}-01$ & $<1.85 \mathrm{E}-01$ & $<1.88 \mathrm{E}-01$ & $<1.84 \mathrm{E}-01$ & $<1.92 \mathrm{E}-01$ \\
\hline 130 & $<1.76 \mathrm{E}+00$ & $<1.72 \mathrm{E}+00$ & $<1.03 \mathrm{E}+00$ & $<9.96 \mathrm{E}-01$ & $<1.03 \mathrm{E}+00$ & $<1.04 \mathrm{E}+00$ & $<1.02 \mathrm{E}+00$ & $<1.06 \mathrm{E}+00$ \\
\hline 133 & $1.64 \mathrm{E}+00$ & $1.53 \mathrm{E}+00$ & $1.64 \mathrm{E}+00$ & $1.75 \mathrm{E}+00$ & $1.73 \mathrm{E}+00$ & $1.86 \mathrm{E}+00$ & $1.93 \mathrm{E}+00$ & $1.82 \mathrm{E}+00$ \\
\hline 134 & $<8.99 \mathrm{E}-01$ & $<8.79 \mathrm{E}-01$ & $<5.26 \mathrm{E}-01$ & $<5.08 \mathrm{E}-01$ & $<5.24 \mathrm{E}-01$ & $<5.32 \mathrm{E}-01$ & $<5.20 \mathrm{E}-01$ & $<5.42 \mathrm{E}-01$ \\
\hline 135 & $2.36 \mathrm{E}-01$ & $2.05 \mathrm{E}-01$ & $2.28 \mathrm{E}-01$ & 2.14E-01 & $1.99 \mathrm{E}-01$ & $2.30 \mathrm{E}-01$ & $2.44 \mathrm{E}-01$ & $2.05 \mathrm{E}-01$ \\
\hline 136 & $<9.37 \mathrm{E}-02$ & $<9.15 \mathrm{E}-02$ & $<5.48 \mathrm{E}-02$ & $<5.30 \mathrm{E}-02$ & $<5.45 \mathrm{E}-02$ & 5.54E-02 & $<5.41 \mathrm{E}-02$ & $5.64 \mathrm{E}-02$ \\
\hline 137 & 4.87E-01 & 4.77E-01 & $6.10 \mathrm{E}-01$ & $5.40 \mathrm{E}-01$ & $5.65 \mathrm{E}-01$ & $5.36 \mathrm{E}-01$ & 5.94E-01 & $5.65 \mathrm{E}-01$ \\
\hline 138 & $<9.37 \mathrm{E}-02$ & $<9.15 \mathrm{E}-02$ & $<5.48 \mathrm{E}-02$ & $<5.30 \mathrm{E}-02$ & $<5.45 \mathrm{E}-02$ & $<5.54 \mathrm{E}-02$ & $<5.41 \mathrm{E}-02$ & $<5.64 \mathrm{E}-02$ \\
\hline 139 & $<7.49 \mathrm{E}-02$ & $<7.32 \mathrm{E}-02$ & $<4.38 \mathrm{E}-02$ & $<4.24 \mathrm{E}-02$ & $<4.36 \mathrm{E}-02$ & $<4.43 \mathrm{E}-02$ & $<4.33 \mathrm{E}-02$ & $<4.52 \mathrm{E}-02$ \\
\hline 140 & $<9.37 \mathrm{E}-02$ & $<9.15 \mathrm{E}-02$ & $<5.48 \mathrm{E}-02$ & $<5.30 \mathrm{E}-02$ & $<5.45 \mathrm{E}-02$ & $<5.54 \mathrm{E}-02$ & $<5.41 \mathrm{E}-02$ & $<5.64 \mathrm{E}-02$ \\
\hline 141 & $<5.62 \mathrm{E}-02$ & $<5.49 \mathrm{E}-02$ & $<3.29 \mathrm{E}-02$ & $<3.18 \mathrm{E}-02$ & $<3.27 \mathrm{E}-02$ & $<3.32 \mathrm{E}-02$ & $<3.25 \mathrm{E}-02$ & $<3.39 \mathrm{E}-02$ \\
\hline 142 & $<3.75 \mathrm{E}-02$ & $<3.66 \mathrm{E}-02$ & $<2.19 \mathrm{E}-02$ & $<2.12 \mathrm{E}-02$ & $<2.18 \mathrm{E}-02$ & $<2.21 \mathrm{E}-02$ & $<2.17 \mathrm{E}-02$ & $<2.26 \mathrm{E}-02$ \\
\hline 143 & $<3.75 \mathrm{E}-02$ & $<3.66 \mathrm{E}-02$ & $<2.19 \mathrm{E}-02$ & $<2.12 \mathrm{E}-02$ & $<2.18 \mathrm{E}-02$ & $<2.21 \mathrm{E}-02$ & $<2.17 \mathrm{E}-02$ & $<2.26 \mathrm{E}-02$ \\
\hline 144 & $<3.75 \mathrm{E}-02$ & $<3.66 \mathrm{E}-02$ & $<2.19 \mathrm{E}-02$ & $<2.12 \mathrm{E}-02$ & $<2.18 \mathrm{E}-02$ & $<2.21 \mathrm{E}-02$ & $<2.17 \mathrm{E}-02$ & $<2.26 \mathrm{E}-02$ \\
\hline 145 & $<3.75 \mathrm{E}-02$ & $<3.66 \mathrm{E}-02$ & $<2.19 \mathrm{E}-02$ & $<2.12 \mathrm{E}-02$ & $<2.18 \mathrm{E}-02$ & $<2.21 \mathrm{E}-02$ & $<2.17 \mathrm{E}-02$ & $<2.26 \mathrm{E}-02$ \\
\hline 146 & $<3.75 \mathrm{E}-02$ & $<3.66 \mathrm{E}-02$ & $<2.19 \mathrm{E}-02$ & $<2.12 \mathrm{E}-02$ & $<2.18 \mathrm{E}-02$ & $<2.21 \mathrm{E}-02$ & $<2.17 \mathrm{E}-02$ & $<2.26 \mathrm{E}-02$ \\
\hline 147 & $<3.75 \mathrm{E}-02$ & $<3.66 \mathrm{E}-02$ & $<2.19 \mathrm{E}-02$ & $<2.12 \mathrm{E}-02$ & $<2.18 \mathrm{E}-02$ & $<2.21 \mathrm{E}-02$ & $<2.17 \mathrm{E}-02$ & $<2.26 \mathrm{E}-02$ \\
\hline 148 & $<3.75 \mathrm{E}-02$ & $<3.66 \mathrm{E}-02$ & $<2.19 \mathrm{E}-02$ & $<2.12 \mathrm{E}-02$ & $<2.18 \mathrm{E}-02$ & $<2.21 \mathrm{E}-02$ & $<2.17 \mathrm{E}-02$ & $<2.26 \mathrm{E}-02$ \\
\hline 149 & $<3.75 \mathrm{E}-02$ & $<3.66 \mathrm{E}-02$ & $<2.19 \mathrm{E}-02$ & $<2.12 \mathrm{E}-02$ & $<2.18 \mathrm{E}-02$ & $<2.21 \mathrm{E}-02$ & $<2.17 \mathrm{E}-02$ & $<2.26 \mathrm{E}-02$ \\
\hline 150 & $<3.75 \mathrm{E}-02$ & $<3.66 \mathrm{E}-02$ & $<2.19 \mathrm{E}-02$ & $<2.12 \mathrm{E}-02$ & $<2.18 \mathrm{E}-02$ & $<2.21 \mathrm{E}-02$ & $<2.17 \mathrm{E}-02$ & $<2.26 \mathrm{E}-02$ \\
\hline 151 & $<5.62 \mathrm{E}-02$ & $<5.49 \mathrm{E}-02$ & $<3.29 \mathrm{E}-02$ & $<3.18 \mathrm{E}-02$ & $<3.27 \mathrm{E}-02$ & $<3.32 \mathrm{E}-02$ & $<3.25 \mathrm{E}-02$ & $<3.39 \mathrm{E}-02$ \\
\hline 152 & $<7.49$ E-02 & $<7.32 \mathrm{E}-02$ & $<4.38 \mathrm{E}-02$ & $<4.24 \mathrm{E}-02$ & $<4.36 \mathrm{E}-02$ & $<4.43 \mathrm{E}-02$ & $<4.33 \mathrm{E}-02$ & $<4.52 \mathrm{E}-02$ \\
\hline 153 & $<3.75 \mathrm{E}-02$ & $<3.66 \mathrm{E}-02$ & $<2.19 \mathrm{E}-02$ & $<2.12 \mathrm{E}-02$ & $<2.18 \mathrm{E}-02$ & $<2.21 \mathrm{E}-02$ & $<2.17 \mathrm{E}-02$ & $<2.26 \mathrm{E}-02$ \\
\hline 154 & $<3.75 \mathrm{E}-02$ & $<3.66 \mathrm{E}-02$ & $<2.19 \mathrm{E}-02$ & $<2.12 \mathrm{E}-02$ & $<2.18 \mathrm{E}-02$ & $<2.21 \mathrm{E}-02$ & $<2.17 \mathrm{E}-02$ & $<2.26 \mathrm{E}-02$ \\
\hline 155 & $<3.75 \mathrm{E}-02$ & $<3.66 \mathrm{E}-02$ & $<2.19 \mathrm{E}-02$ & $<2.12 \mathrm{E}-02$ & $<2.18 \mathrm{E}-02$ & $<2.21 \mathrm{E}-02$ & $<2.17 \mathrm{E}-02$ & $<2.26 \mathrm{E}-02$ \\
\hline 156 & $<3.75 \mathrm{E}-02$ & $<3.66 \mathrm{E}-02$ & $<2.19 \mathrm{E}-02$ & $<2.12 \mathrm{E}-02$ & $<2.18 \mathrm{E}-02$ & $<2.21 \mathrm{E}-02$ & $<2.17 \mathrm{E}-02$ & $<2.26 \mathrm{E}-02$ \\
\hline 157 & $<3.75 \mathrm{E}-02$ & $<3.66 \mathrm{E}-02$ & $<2.19 \mathrm{E}-02$ & $<2.12 \mathrm{E}-02$ & $<2.18 \mathrm{E}-02$ & $<2.21 \mathrm{E}-02$ & $<2.17 \mathrm{E}-02$ & $<2.26 \mathrm{E}-02$ \\
\hline 158 & $<3.75 \mathrm{E}-02$ & $<3.66 \mathrm{E}-02$ & $<2.19$ E-02 & $<2.12 \mathrm{E}-02$ & $<2.18 \mathrm{E}-02$ & $<2.21 \mathrm{E}-02$ & $<2.17 \mathrm{E}-02$ & $<2.26 \mathrm{E}-02$ \\
\hline 159 & $<5.62 \mathrm{E}-02$ & $<5.49 \mathrm{E}-02$ & $<3.29 \mathrm{E}-02$ & $<3.18 \mathrm{E}-02$ & $<3.27 \mathrm{E}-02$ & $<3.32 \mathrm{E}-02$ & $<3.25 \mathrm{E}-02$ & $<3.39 \mathrm{E}-02$ \\
\hline 160 & $<5.62 \mathrm{E}-02$ & $<5.49 \mathrm{E}-02$ & $<3.29 \mathrm{E}-02$ & $<3.18 \mathrm{E}-02$ & $<3.27 \mathrm{E}-02$ & $<3.32 \mathrm{E}-02$ & $<3.25 \mathrm{E}-02$ & $<3.39 \mathrm{E}-02$ \\
\hline 161 & $<3.75 \mathrm{E}-02$ & $<3.66 \mathrm{E}-02$ & $<2.19 \mathrm{E}-02$ & $<2.12 \mathrm{E}-02$ & $<2.18 \mathrm{E}-02$ & $<2.21 \mathrm{E}-02$ & $<2.17 \mathrm{E}-02$ & $<2.26 \mathrm{E}-02$ \\
\hline 162 & $<3.75 \mathrm{E}-02$ & $<3.66 \mathrm{E}-02$ & $<2.19 \mathrm{E}-02$ & $<2.12 \mathrm{E}-02$ & $<2.18 \mathrm{E}-02$ & $<2.21 \mathrm{E}-02$ & $<2.17 \mathrm{E}-02$ & $<2.26 \mathrm{E}-02$ \\
\hline 163 & $<3.75 \mathrm{E}-02$ & $<3.66 \mathrm{E}-02$ & $<2.19 \mathrm{E}-02$ & $<2.12 \mathrm{E}-02$ & $<2.18 \mathrm{E}-02$ & $<2.21 \mathrm{E}-02$ & $<2.17 \mathrm{E}-02$ & $<2.26 \mathrm{E}-02$ \\
\hline 164 & $<3.75 \mathrm{E}-02$ & $<3.66 \mathrm{E}-02$ & $<2.19 \mathrm{E}-02$ & $<2.12 \mathrm{E}-02$ & $<2.18 \mathrm{E}-02$ & $<2.21 \mathrm{E}-02$ & $<2.17 \mathrm{E}-02$ & $<2.26 \mathrm{E}-02$ \\
\hline 165 & $<3.75 \mathrm{E}-02$ & $<3.66 \mathrm{E}-02$ & $<2.19 \mathrm{E}-02$ & $<2.12 \mathrm{E}-02$ & $<2.18 \mathrm{E}-02$ & $<2.21 \mathrm{E}-02$ & $<2.17 \mathrm{E}-02$ & $<2.26 \mathrm{E}-02$ \\
\hline 166 & $<3.75 \mathrm{E}-02$ & $<3.66 \mathrm{E}-02$ & $<2.19 \mathrm{E}-02$ & $<2.12 \mathrm{E}-02$ & $<2.18 \mathrm{E}-02$ & $<2.21 \mathrm{E}-02$ & $<2.17 \mathrm{E}-02$ & $<2.26 \mathrm{E}-02$ \\
\hline 167 & $<5.62 \mathrm{E}-02$ & $<5.49 \mathrm{E}-02$ & $<3.29 \mathrm{E}-02$ & $<3.18 \mathrm{E}-02$ & $<3.27 \mathrm{E}-02$ & $<3.32 \mathrm{E}-02$ & $<3.25 \mathrm{E}-02$ & $<3.39 \mathrm{E}-02$ \\
\hline 168 & $<5.62 \mathrm{E}-02$ & $<5.49 \mathrm{E}-02$ & $<3.29 \mathrm{E}-02$ & $<3.18 \mathrm{E}-02$ & $<3.27 \mathrm{E}-02$ & $<3.32 \mathrm{E}-02$ & $<3.25 \mathrm{E}-02$ & $<3.39 \mathrm{E}-02$ \\
\hline 169 & $<5.62 \mathrm{E}-02$ & $<5.49 \mathrm{E}-02$ & $<3.29 \mathrm{E}-02$ & $<3.18 \mathrm{E}-02$ & $<3.27 \mathrm{E}-02$ & $<3.32 \mathrm{E}-02$ & $<3.25 \mathrm{E}-02$ & $<3.39 \mathrm{E}-02$ \\
\hline 170 & $<5.62 \mathrm{E}-02$ & $<5.49 \mathrm{E}-02$ & $<3.29 \mathrm{E}-02$ & $<3.18 \mathrm{E}-02$ & $<3.27 \mathrm{E}-02$ & $<3.32 \mathrm{E}-02$ & $<3.25 \mathrm{E}-02$ & $<3.39 \mathrm{E}-02$ \\
\hline 171 & $<3.75 \mathrm{E}-02$ & $<3.66 \mathrm{E}-02$ & $<2.19 \mathrm{E}-02$ & $<2.12 \mathrm{E}-02$ & $<2.18 \mathrm{E}-02$ & $<2.21 \mathrm{E}-02$ & $<2.17 \mathrm{E}-02$ & $<2.26 \mathrm{E}-02$ \\
\hline 172 & $<5.62 \mathrm{E}-02$ & $<5.49 \mathrm{E}-02$ & $<3.29 \mathrm{E}-02$ & $<3.18 \mathrm{E}-02$ & $<3.27 \mathrm{E}-02$ & $<3.32 \mathrm{E}-02$ & $<3.25 \mathrm{E}-02$ & $<3.39 \mathrm{E}-02$ \\
\hline
\end{tabular}


Table A-5. ICP-MS results for acid dilutions of evaporator scale contact tests (contd.)

\begin{tabular}{|c|c|c|c|c|c|c|c|c|}
\hline hold time (days) & 0 & 0 & 19 & 19 & 20 & 19 & 20 & 20 \\
\hline glycolate $(\mathrm{g} / \mathrm{L})$ & 0 & 10 & 0 & 0 & 0 & 10 & 10 & 10 \\
\hline $\mathrm{DF}(\mathrm{mL} / \mathrm{mL})$ & 18.73 & 18.31 & 10.96 & 10.59 & 10.91 & 11.07 & 10.83 & 11.29 \\
\hline LIMS numbers & 300304639 & 300304641 & 300304643 & 300304645 & 300304647 & 300304644 & 300304646 & 300304648 \\
\hline $\operatorname{mass}(\mathrm{m} / \mathrm{z})=173$ & $<3.75 \mathrm{E}-02$ & $<3.66 \mathrm{E}-02$ & $<2.19 \mathrm{E}-02$ & $<2.12 \mathrm{E}-02$ & $<2.18 \mathrm{E}-02$ & $<2.21 \mathrm{E}-02$ & $<2.17 \mathrm{E}-02$ & $<2.26 \mathrm{E}-02$ \\
\hline 174 & $<3.75 \mathrm{E}-02$ & $<3.66 \mathrm{E}-02$ & $<2.19 \mathrm{E}-02$ & $<2.12 \mathrm{E}-02$ & $<2.18 \mathrm{E}-02$ & $<2.21 \mathrm{E}-02$ & $<2.17 \mathrm{E}-02$ & $<2.26 \mathrm{E}-02$ \\
\hline 175 & $<3.75 \mathrm{E}-02$ & $<3.66 \mathrm{E}-02$ & $<2.19 \mathrm{E}-02$ & $<2.12 \mathrm{E}-02$ & $<2.18 \mathrm{E}-02$ & $<2.21 \mathrm{E}-02$ & $<2.17 \mathrm{E}-02$ & $<2.26 \mathrm{E}-02$ \\
\hline 176 & $<3.75 \mathrm{E}-02$ & $<3.66 \mathrm{E}-02$ & $<2.19 \mathrm{E}-02$ & $<2.12 \mathrm{E}-02$ & $<2.18 \mathrm{E}-02$ & $<2.21 \mathrm{E}-02$ & $<2.17 \mathrm{E}-02$ & $<2.26 \mathrm{E}-02$ \\
\hline 177 & $<3.75 \mathrm{E}-02$ & $<3.66 \mathrm{E}-02$ & $<2.19 \mathrm{E}-02$ & $<2.12 \mathrm{E}-02$ & $<2.18 \mathrm{E}-02$ & $<2.21 \mathrm{E}-02$ & $<2.17 \mathrm{E}-02$ & $<2.26 \mathrm{E}-02$ \\
\hline 178 & $<7.49 \mathrm{E}-02$ & $<7.32 \mathrm{E}-02$ & $<4.38 \mathrm{E}-02$ & $<4.24 \mathrm{E}-02$ & $<4.36 \mathrm{E}-02$ & $<4.43 \mathrm{E}-02$ & $<4.33 \mathrm{E}-02$ & $<4.52 \mathrm{E}-02$ \\
\hline 179 & $<1.12 \mathrm{E}-01$ & $<1.10 \mathrm{E}-01$ & $<6.57 \mathrm{E}-02$ & $<6.36 \mathrm{E}-02$ & $<6.55 \mathrm{E}-02$ & $<6.64 \mathrm{E}-02$ & $<6.50 \mathrm{E}-02$ & $<6.77 \mathrm{E}-02$ \\
\hline 180 & $<1.50 \mathrm{E}-01$ & $<1.46 \mathrm{E}-01$ & $<8.77 \mathrm{E}-02$ & $<8.47 \mathrm{E}-02$ & $<8.73 \mathrm{E}-02$ & $<8.86 \mathrm{E}-02$ & $<8.66 \mathrm{E}-02$ & $<9.03 \mathrm{E}-02$ \\
\hline 181 & $<3.18 \mathrm{E}-01$ & $<3.11 \mathrm{E}-01$ & $<1.86 \mathrm{E}-01$ & $<1.80 \mathrm{E}-01$ & $<1.85 \mathrm{E}-01$ & $<1.88 \mathrm{E}-01$ & $<1.84 \mathrm{E}-01$ & $<1.92 \mathrm{E}-01$ \\
\hline 182 & 2.39E-01 & $1.78 \mathrm{E}-01$ & $2.38 \mathrm{E}-01$ & $1.97 \mathrm{E}-01$ & $2.16 \mathrm{E}-01$ & 2.23E-01 & $2.16 \mathrm{E}-01$ & $2.16 \mathrm{E}-01$ \\
\hline 183 & $1.38 \mathrm{E}-01$ & $<1.28 \mathrm{E}-01$ & $1.32 \mathrm{E}-01$ & $1.28 \mathrm{E}-01$ & $1.29 \mathrm{E}-01$ & 1.69E-01 & $1.35 \mathrm{E}-01$ & $1.29 \mathrm{E}-01$ \\
\hline 184 & $3.36 \mathrm{E}-01$ & 2.89E-01 & $2.52 \mathrm{E}-01$ & $2.65 \mathrm{E}-01$ & 2.53E-01 & $3.20 \mathrm{E}-01$ & 2.92E-01 & $2.75 \mathrm{E}-01$ \\
\hline 185 & $<1.31 \mathrm{E}-01$ & $<1.28 \mathrm{E}-01$ & $<7.67 \mathrm{E}-02$ & $<7.41 \mathrm{E}-02$ & $<7.64 \mathrm{E}-02$ & $<7.75 \mathrm{E}-02$ & $<7.58 \mathrm{E}-02$ & $<7.90 \mathrm{E}-02$ \\
\hline 186 & $2.45 \mathrm{E}-01$ & $2.51 \mathrm{E}-01$ & 2.32E-01 & $2.71 \mathrm{E}-01$ & $2.40 \mathrm{E}-01$ & $2.67 \mathrm{E}-01$ & $2.36 \mathrm{E}-01$ & $2.63 \mathrm{E}-01$ \\
\hline 187 & $<5.62 \mathrm{E}-02$ & $<5.49 \mathrm{E}-02$ & $<3.29 \mathrm{E}-02$ & $<3.18 \mathrm{E}-02$ & $<3.27 \mathrm{E}-02$ & $<3.32 \mathrm{E}-02$ & $<3.25 \mathrm{E}-02$ & $<3.39 \mathrm{E}-02$ \\
\hline 191 & $<9.37 \mathrm{E}-02$ & $<9.15 \mathrm{E}-02$ & $<5.48 \mathrm{E}-02$ & $<5.30 \mathrm{E}-02$ & $<5.45 \mathrm{E}-02$ & $<5.54 \mathrm{E}-02$ & $<5.41 \mathrm{E}-02$ & $<5.64 \mathrm{E}-02$ \\
\hline 193 & $<1.12 \mathrm{E}-01$ & $<1.10 \mathrm{E}-01$ & $<6.57 \mathrm{E}-02$ & $<6.36 \mathrm{E}-02$ & $<6.55 \mathrm{E}-02$ & $<6.64 \mathrm{E}-02$ & $<6.50 \mathrm{E}-02$ & $<6.77 \mathrm{E}-02$ \\
\hline 194 & $<1.50 \mathrm{E}-01$ & $<1.46 \mathrm{E}-01$ & $<8.77 \mathrm{E}-02$ & $<8.47 \mathrm{E}-02$ & $<8.73 \mathrm{E}-02$ & $<8.86 \mathrm{E}-02$ & $<8.66 \mathrm{E}-02$ & $<9.03 \mathrm{E}-02$ \\
\hline 195 & $<1.31 \mathrm{E}-01$ & $<1.28 \mathrm{E}-01$ & $<7.67 \mathrm{E}-02$ & $<7.41 \mathrm{E}-02$ & $<7.64 \mathrm{E}-02$ & $<7.75 \mathrm{E}-02$ & $<7.58 \mathrm{E}-02$ & $<7.90 \mathrm{E}-02$ \\
\hline 196 & $3.16 \mathrm{E}-01$ & $1.54 \mathrm{E}-01$ & $3.06 \mathrm{E}-01$ & $3.01 \mathrm{E}-01$ & $3.11 \mathrm{E}-01$ & $2.21 \mathrm{E}-01$ & 2.12E-01 & $2.48 \mathrm{E}-01$ \\
\hline 198 & $1.08 \mathrm{E}+01$ & $7.86 \mathrm{E}+00$ & $1.69 \mathrm{E}+01$ & $1.69 \mathrm{E}+01$ & $1.80 \mathrm{E}+01$ & $1.19 \mathrm{E}+01$ & $1.34 \mathrm{E}+01$ & $1.30 \mathrm{E}+01$ \\
\hline 203 & $<3.75 \mathrm{E}-02$ & $<3.66 \mathrm{E}-02$ & $<2.19 \mathrm{E}-02$ & $<2.12 \mathrm{E}-02$ & $<2.18 \mathrm{E}-02$ & $<2.21 \mathrm{E}-02$ & $<2.17 \mathrm{E}-02$ & $<2.26 \mathrm{E}-02$ \\
\hline 204 & $4.87 \mathrm{E}+00$ & $3.71 \mathrm{E}+00$ & $7.88 \mathrm{E}+00$ & $7.95 \mathrm{E}+00$ & $8.33 \mathrm{E}+00$ & $5.37 \mathrm{E}+00$ & $6.28 \mathrm{E}+00$ & $5.75 \mathrm{E}+00$ \\
\hline 205 & $<3.75 \mathrm{E}-02$ & $<3.66 \mathrm{E}-02$ & $<2.19 \mathrm{E}-02$ & $<2.12 \mathrm{E}-02$ & $<2.18 \mathrm{E}-02$ & $<2.21 \mathrm{E}-02$ & $<2.17 \mathrm{E}-02$ & $<2.26 \mathrm{E}-02$ \\
\hline 206 & $<3.75 \mathrm{E}-02$ & $3.67 \mathrm{E}-02$ & 2.74E-02 & $<2.12 \mathrm{E}-02$ & $9.27 \mathrm{E}-02$ & $<2.21 \mathrm{E}-02$ & $2.60 \mathrm{E}-02$ & $<2.26 \mathrm{E}-02$ \\
\hline 207 & $<3.75 \mathrm{E}-02$ & $<3.66 \mathrm{E}-02$ & $2.72 \mathrm{E}-02$ & 2.42E-02 & 6.92E-02 & $2.85 \mathrm{E}-02$ & 2.95E-02 & 2.52E-02 \\
\hline 208 & 9.91E-02 & $7.83 \mathrm{E}-02$ & $6.40 \mathrm{E}-02$ & $<4.24 \mathrm{E}-02$ & $39 \mathrm{E}-01$ & $<4.43 \mathrm{E}-02$ & $6.82 \mathrm{E}-02$ & 4.80E-02 \\
\hline 230 & $<3.75 \mathrm{E}-02$ & $<3.66 \mathrm{E}-02$ & $<2.19 \mathrm{E}-02$ & $<2.12 \mathrm{E}-02$ & $<2.18 \mathrm{E}-02$ & $<2.21 \mathrm{E}-02$ & $<2.17 \mathrm{E}-02$ & $<2.26 \mathrm{E}-02$ \\
\hline 232 & $<3.75 \mathrm{E}-02$ & $<3.66 \mathrm{E}-02$ & $<2.19 \mathrm{E}-02$ & $<2.12 \mathrm{E}-02$ & $<2.18 \mathrm{E}-02$ & $<2.21 \mathrm{E}-02$ & $<2.17 \mathrm{E}-02$ & $<2.26 \mathrm{E}-02$ \\
\hline 233 & $<3.75 \mathrm{E}-02$ & $<3.66 \mathrm{E}-02$ & $<2.19 \mathrm{E}-02$ & $<2.12 \mathrm{E}-02$ & $<2.18 \mathrm{E}-02$ & $<2.21 \mathrm{E}-02$ & $<2.17 \mathrm{E}-02$ & $<2.26 \mathrm{E}-02$ \\
\hline 234 & $<3.75 \mathrm{E}-02$ & $<3.66 \mathrm{E}-02$ & $<2.19 \mathrm{E}-02$ & $<2.12 \mathrm{E}-02$ & $<2.18 \mathrm{E}-02$ & $<2.21 \mathrm{E}-02$ & $<2.17 \mathrm{E}-02$ & $<2.26 \mathrm{E}-02$ \\
\hline 235 & $<3.75 \mathrm{E}-02$ & $<3.66 \mathrm{E}-02$ & $6.26 \mathrm{E}-02$ & 5.04E-02 & $3.98 \mathrm{E}-02$ & $5.33 \mathrm{E}-02$ & $5.04 \mathrm{E}-02$ & $6.16 \mathrm{E}-02$ \\
\hline 236 & $<3.75 \mathrm{E}-02$ & $<3.66 \mathrm{E}-02$ & $<2.19 \mathrm{E}-02$ & $<2.12 \mathrm{E}-02$ & $<2.18 \mathrm{E}-02$ & $<2.21 \mathrm{E}-02$ & $<2.17 \mathrm{E}-02$ & $<2.26 \mathrm{E}-02$ \\
\hline 237 & $<3.75 \mathrm{E}-02$ & $<3.66 \mathrm{E}-02$ & $<2.19 \mathrm{E}-02$ & $<2.12 \mathrm{E}-02$ & $<2.18 \mathrm{E}-02$ & $<2.21 \mathrm{E}-02$ & $<2.17 \mathrm{E}-02$ & $<2.26 \mathrm{E}-02$ \\
\hline 238 & $2.59 \mathrm{E}+00$ & $5.84 \mathrm{E}+00$ & $5.88 \mathrm{E}+00$ & $7.05 \mathrm{E}+00$ & $6.25 \mathrm{E}+00$ & $7.12 \mathrm{E}+00$ & $6.98 \mathrm{E}+00$ & $6.59 \mathrm{E}+00$ \\
\hline 239 & $<3.75 \mathrm{E}-02$ & $<3.66 \mathrm{E}-02$ & $<2.19 \mathrm{E}-02$ & $<2.12 \mathrm{E}-02$ & $<2.18 \mathrm{E}-02$ & $<2.21 \mathrm{E}-02$ & $<2.17 \mathrm{E}-02$ & $<2.26 \mathrm{E}-02$ \\
\hline 240 & $<3.75 \mathrm{E}-02$ & $<3.66 \mathrm{E}-02$ & $<2.19 \mathrm{E}-02$ & $<2.12 \mathrm{E}-02$ & $<2.18 \mathrm{E}-02$ & $<2.21 \mathrm{E}-02$ & $<2.17 \mathrm{E}-02$ & $<2.26 \mathrm{E}-02$ \\
\hline 241 & $<3.75 \mathrm{E}-02$ & $<3.66 \mathrm{E}-02$ & $<2.19 \mathrm{E}-02$ & $<2.12 \mathrm{E}-02$ & $<2.18 \mathrm{E}-02$ & $<2.21 \mathrm{E}-02$ & $<2.17 \mathrm{E}-02$ & $<2.26 \mathrm{E}-02$ \\
\hline 242 & $<3.75 \mathrm{E}-02$ & $<3.66 \mathrm{E}-02$ & $<2.19 \mathrm{E}-02$ & $<2.12 \mathrm{E}-02$ & $<2.18 \mathrm{E}-02$ & $<2.21 \mathrm{E}-02$ & $<2.17 \mathrm{E}-02$ & $<2.26 \mathrm{E}-02$ \\
\hline 243 & $<3.75 \mathrm{E}-02$ & $<3.66 \mathrm{E}-02$ & $<2.19 \mathrm{E}-02$ & $<2.12 \mathrm{E}-02$ & $<2.18 \mathrm{E}-02$ & $<2.21 \mathrm{E}-02$ & $<2.17 \mathrm{E}-02$ & $<2.26 \mathrm{E}-02$ \\
\hline 244 & $<3.75 \mathrm{E}-02$ & $<3.66 \mathrm{E}-02$ & $<2.19 \mathrm{E}-02$ & $<2.12 \mathrm{E}-02$ & $<2.18 \mathrm{E}-02$ & $<2.21 \mathrm{E}-02$ & $<2.17 \mathrm{E}-02$ & $<2.26 \mathrm{E}-02$ \\
\hline
\end{tabular}


Table A-6. Analysis results for water dilutions of evaporator scale contact tests

\begin{tabular}{|c|c|c|c|c|c|c|c|c|}
\hline hold time (days) & 0 & 0 & 19 & 19 & 20 & 19 & 20 & 20 \\
\hline glycolate $(\mathrm{g} / \mathrm{L})$ & 0 & 10 & 0 & 0 & 0 & 10 & 10 & 10 \\
\hline $\mathrm{DF}(\mathrm{mL} / \mathrm{mL})$ & 15.81 & 15.67 & 11.92 & 11.36 & 11.12 & 11.27 & 11.05 & 11.74 \\
\hline \multirow[t]{2}{*}{ LIMS numbers } & 300304659 & 300304661 & 300304663 & 300304665 & 300304667 & 300304664 & 300304666 & 300304668 \\
\hline & 300304669 & 300304671 & 300304673 & 300304675 & 300304677 & 300304674 & 300304676 & 300304678 \\
\hline \multicolumn{9}{|c|}{ IC Anions (mg/L) } \\
\hline Glycolate & $<7.90 E+02$ & $6.36 E+03$ & $<5.96 E+02$ & $<5.68 E+02$ & $<5.56 E+02$ & $6.62 E+03$ & $6.65 E+03$ & $5.91 E+03$ \\
\hline Fluoride & $<7.90 \mathrm{E}+02$ & $<7.84 \mathrm{E}+02$ & $<5.96 \mathrm{E}+02$ & $<5.68 \mathrm{E}+02$ & $<5.56 \mathrm{E}+02$ & $<5.63 \mathrm{E}+02$ & $<5.52 \mathrm{E}+02$ & $<5.87 \mathrm{E}+02$ \\
\hline Formate & $1.42 \mathrm{E}+03$ & $3.71 \mathrm{E}+03$ & $1.45 \mathrm{E}+03$ & $1.50 \mathrm{E}+03$ & $1.48 \mathrm{E}+03$ & $4.56 \mathrm{E}+03$ & $4.76 \mathrm{E}+03$ & $4.18 \mathrm{E}+03$ \\
\hline Chloride & $<7.90 \mathrm{E}+02$ & $<7.84 \mathrm{E}+02$ & $<5.96 \mathrm{E}+02$ & $<5.68 \mathrm{E}+02$ & $<5.56 \mathrm{E}+02$ & $<5.63 \mathrm{E}+02$ & $<5.52 \mathrm{E}+02$ & $<5.87 \mathrm{E}+02$ \\
\hline Nitrite & $6.76 \mathrm{E}+04$ & $6.71 \mathrm{E}+04$ & $7.04 \mathrm{E}+04$ & $7.26 \mathrm{E}+04$ & $7.00 \mathrm{E}+04$ & $7.57 \mathrm{E}+04$ & $7.81 \mathrm{E}+04$ & $6.88 \mathrm{E}+04$ \\
\hline Bromide & $<7.90 \mathrm{E}+03$ & $<7.84 \mathrm{E}+03$ & $<5.96 \mathrm{E}+03$ & $<5.68 \mathrm{E}+03$ & $<5.56 \mathrm{E}+03$ & $<5.63 \mathrm{E}+03$ & $<5.52 \mathrm{E}+03$ & $<5.87 \mathrm{E}+03$ \\
\hline Nitrate & $5.17 \mathrm{E}+04$ & $5.14 \mathrm{E}+04$ & $5.42 \mathrm{E}+04$ & $6.10 \mathrm{E}+04$ & $5.43 \mathrm{E}+04$ & $5.83 \mathrm{E}+04$ & $6.02 \mathrm{E}+04$ & $5.32 \mathrm{E}+04$ \\
\hline Phosphate & $2.69 \mathrm{E}+02$ & $2.66 \mathrm{E}+02$ & $2.86 \mathrm{E}+02$ & $2.95 \mathrm{E}+02$ & $3.00 \mathrm{E}+02$ & $3.16 \mathrm{E}+02$ & $3.31 \mathrm{E}+02$ & $2.94 \mathrm{E}+02$ \\
\hline Sulfate & $2.02 \mathrm{E}+03$ & $1.96 \mathrm{E}+03$ & $2.04 \mathrm{E}+03$ & $2.00 \mathrm{E}+03$ & $1.93 \mathrm{E}+03$ & $2.11 \mathrm{E}+03$ & $2.09 \mathrm{E}+03$ & $1.90 \mathrm{E}+03$ \\
\hline Oxalate & $3.64 \mathrm{E}+02$ & $7.52 \mathrm{E}+02$ & $5.60 \mathrm{E}+02$ & $5.46 \mathrm{E}+02$ & $5.56 \mathrm{E}+02$ & $1.28 \mathrm{E}+03$ & $1.52 \mathrm{E}+03$ & $1.30 \mathrm{E}+03$ \\
\hline \multicolumn{9}{|c|}{ TIC/TOC (mg C/L) } \\
\hline Total Carbon & $5.12 \mathrm{E}+03$ & $8.46 \mathrm{E}+03$ & $5.98 \mathrm{E}+03$ & $6.00 \mathrm{E}+03$ & $5.71 \mathrm{E}+03$ & $1.06 \mathrm{E}+04$ & $1.10 \mathrm{E}+04$ & $9.35 \mathrm{E}+03$ \\
\hline Inorganic Carbon & $4.46 \mathrm{E}+03$ & $4.95 \mathrm{E}+03$ & $4.70 \mathrm{E}+03$ & $4.86 \mathrm{E}+03$ & $4.67 \mathrm{E}+03$ & $5.86 \mathrm{E}+03$ & $6.19 \mathrm{E}+03$ & $5.31 \mathrm{E}+03$ \\
\hline Organic Carbon & $6.64 \mathrm{E}+02$ & $3.51 \mathrm{E}+03$ & $1.29 \mathrm{E}+03$ & $1.14 \mathrm{E}+03$ & $1.05 \mathrm{E}+03$ & $4.73 \mathrm{E}+03$ & $4.86 \mathrm{E}+03$ & $4.04 \mathrm{E}+03$ \\
\hline \multicolumn{9}{|c|}{ Titration (M) } \\
\hline Total Base & $2.48 \mathrm{E}+00$ & $2.37 \mathrm{E}+00$ & $2.41 \mathrm{E}+00$ & $2.58 \mathrm{E}+00$ & $2.39 \mathrm{E}+00$ & $3.53 \mathrm{E}+00$ & $2.26 \mathrm{E}+00$ & $2.03 \mathrm{E}+00$ \\
\hline Free Hydroxide & $2.17 \mathrm{E}+00$ & $2.07 \mathrm{E}+00$ & $2.16 \mathrm{E}+00$ & $2.04 \mathrm{E}+00$ & $2.16 \mathrm{E}+00$ & $2.23 \mathrm{E}+00$ & $2.05 \mathrm{E}+00$ & $1.96 \mathrm{E}+00$ \\
\hline Other Base* & $<3.16 \mathrm{E}-01$ & $<3.13 \mathrm{E}-01$ & $<2.38 \mathrm{E}-01$ & $<2.25 \mathrm{E}-01$ & $<2.27 \mathrm{E}-01$ & $<2.21 \mathrm{E}-01$ & $<2.22 \mathrm{E}-01$ & $<2.35 \mathrm{E}-01$ \\
\hline
\end{tabular}

* Other Base excluding carbonate 